\title{
Site U1389'
}

\author{
Expedition 339 Scientists $^{2}$
}

\section{Chapter contents}

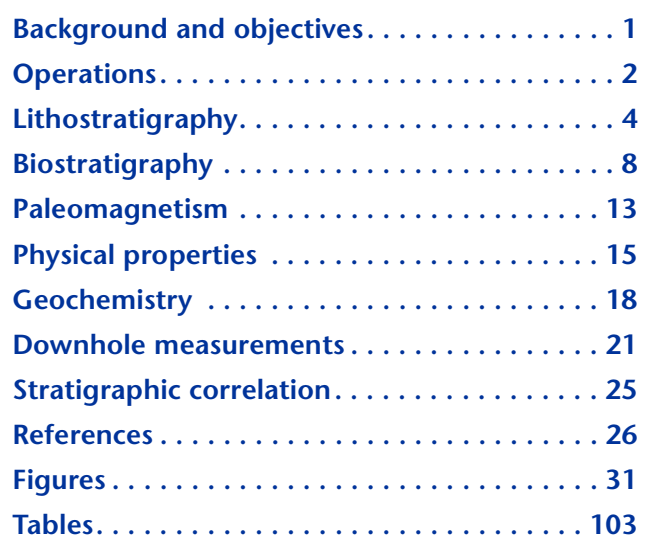

${ }^{1}$ Expedition 339 Scientists, 2013. Site U1389. In Stow, D.A.V., Hernández-Molina, F.J., Alvarez Zarikian, C.A., and the Expedition 339 Scientists, Proc. IODP, 339: Tokyo (Integrated Ocean Drilling Program Management International, Inc.). doi:10.2204/iodp.proc.339.107.2013

'Expedition 339 Scientists' addresses.

\section{Background and objectives}

Integrated Ocean Drilling Program (IODP) Site U1389 $\left(36^{\circ} 25.515^{\prime} \mathrm{N}, 7^{\circ} 16.683^{\prime} \mathrm{W}\right.$; $644 \mathrm{~m}$ water depth) is located in Sector 3 of the contourite depositional system (CDS) (channel and ridge sectors defined by Hernández-Molina et al., 2003, and Llave et al., 2007a) on the northwest side of the Guadalquivir diapiric ridge (Figs. F1, F2). This is an important site for the recovery of a late Pliocene and Pleistocene succession under the influence of the lower core of Mediterranean Outflow Water (MOW).

This sector is located in the central area of the middle slope between Cádiz and Faro, at 800-1600 meters below sea level (mbsl) (Fig. F3), and was first studied by Nelson et al. (1993, 1999) and Baraza et al. (1999), who originally described it as the "Ridge and Valley Province." The sector has been described in more detail recently by several authors (Mulder et al., 2002, 2003; Habgood et al., 2003; Hernández-Molina et al., 2003, 2006; Hanquiez et al., 2007; Llave et al., 2007a; García et al., 2009).

The sector includes some prominent morphostructural features, including the Guadalquivir Bank; the Doñana, Guadalquivir, and Cádiz diapiric ridges; and numerous isolated diapiric highs and mud volcanoes (Fig. F3) that are caused by recent tectonic activity (Maldonado et al., 1999; Maestro et al., 2003; Somoza et al., 2003; Medialdea et al., 2004, 2009; Fernández-Puga et al., 2007; Zitellini et al., 2009). Some of the diapiric ridges occur as a distinctly linear and segmented seafloor relief with a general northeast-southwest trend, whereas others are buried and show an undulating deformational pattern of topographic highs and lows. In this scenario, a complex pattern of erosive features occurs, composed of four types of submarine valleys: contourite moats, contourite channels, marginal valleys, and large isolated furrows (Hernández-Molina et al., 2003, 2006; Llave et al., 2007a; García et al., 2009). As many as nine contourite channels have been identified in this sector by García et al. (2009), with the five larger ones known as the Cádiz, Guadalquivir, Huelva, Diego Cão, and Gusano Channels (Figs. F3, F4). These channels are asymmetrical in cross section, with lengths ranging from 10 to $>100 \mathrm{~km}$, widths ranging from 1.5 to $10 \mathrm{~km}$, and depths ranging from 10 to $350 \mathrm{~m}$, and the incisions are generally greater on the northern flanks (Figs. F4, F5).

Within the contourite channel, the floors are characterized by very high backscatter, representing scoured diapirs, outcrops of 
rock, and rubble partially covered by longitudinal bedforms and regularly spaced dunes (HernándezMolina et al., 2006; Stow et al., 2009, in press). Nelson et al. (1993) identified gravel and shelf lags in the eastern channels and sand in western channels. Contourite channels are broadly S-shaped in plan view, with northwest-southeast-oriented alongslope segments veering to northeast-southwest-oriented downslope segments, caused by the interaction of bottom currents with the irregular morphology of the slope and diapiric ridges (Figs. F3, F4). Several marginal valleys with irregular morphology and a northeast-southwest orientation are noted behind the adjacent diapiric ridge flank, whereas other marginal valleys identified by García et al. (2009) have much more irregular trends. Erosive contourite channels and marginal valleys are present over a broad deformed sheeted drift. This drift represents the main depositional morphology in this sector (Figs. F4, F5), but some patch drifts can be also identified behind local topographic obstacles. The distribution and characteristics of these erosive features allowed García et al. (2009) to propose a new and more precise scheme for the MOW circulation pattern. This scheme includes a main alongslope circulation responsible for the excavation of the contourite moat and channels and a secondary downslope circulation responsible for the erosion of marginal valleys and isolated furrows.

Based on seismic data through the Quaternary period, Llave et al. (2007a) and García et al. (2009) reported important depositional and oceanographic changes associated with tectonic events related to the aforementioned morphostructural features, coeval with the mid-Pleistocene revolution and marine isotope Stage 6. In these two periods, realignment of the diapiric ridges and their segmentation as the result of neotectonic effects led to the development of new local gateways. These affected the distribution of the different branches of the MOW, and hence, the distribution of associated contourite channels. As a result of these tectonic changes, some mounded, elongated, and separated drifts were buried (Figs. F6, F7) under the influence of the lower core of MOW. These are preserved in the sedimentary record (Llave et al., 2007b).

\section{Objectives}

The major objective for Site U1389 was to recover a sedimentary contourite record through the late Pliocene and Pleistocene (see Fig. F17 in the "Expedition 339 summary" chapter [Expedition 339 Scientists, 2013a]) under the influence of the lower core of MOW (Stow et al., 2011). This record will allow us to investigate
- The influence of the Gibraltar Gateway through the Pliocene and Pleistocene in the proximal to middle part of the contourite system;

- MOW paleoceanography for the late Pliocene to Holocene;

- The effects of long- and short-term climate and sea level changes on the sediment architecture of the contourite drift in this sector of the CDS; and

- The stacking and evolution of the previously identified buried, mounded, elongated, and separated drifts developed under the influence of the lower core preserved in the sedimentary record (Llave et al., 2007b).

Specific objectives for Site U1389 include

- Drilling through the sheeted drifts and buried mounded drift succession and into late Pliocene sediments and hence dating the most important intervals for contourite sedimentation in the proximal to middle part of the CDS;

- Evaluating the nature of change in the patterns of sedimentation and microfauna from the late Pliocene through the Holocene;

- Documenting the possible effects of the Gibraltar Gateway through the Pliocene and Pleistocene and hence determining the input variation of MOW influx;

- Reconstructing the main MOW paleoceanographic events for the Pliocene and Pleistocene and identifying the role of MOW in the dynamics of North Atlantic Deep Water;

- Determining the sedimentary stacking pattern and evolution of the buried, mounded, elongated, and separated drifts and the inferred tectonics and/or environmental changes;

- Evaluating the correlation and influence of cold/ warm periods with MOW variation;

- Determining the contourite sequence of facies in relation to changes in sea level and other forcing mechanisms, thereby determining the potential role of variations in cross-sectional area of the Gibraltar Gateway;

- Evaluating periods of drift construction, nondeposition (hiatuses), and erosion; and

- Calibrating and hence understanding the sedimentary cyclicity evident on the contourite deposits, thereby characterizing their sedimentary expression and regional extent.

\section{Operations}

The vessel departed for Site U1389 (proposed Site GC-11A) at $1730 \mathrm{~h}$ on 21 December 2011. The 25 
nmi journey from Site U1388 was accomplished in $2.5 \mathrm{~h}$, and the R/V JOIDES Resolution was positioned on the new site by $2000 \mathrm{~h}$.

Four holes were drilled at Site U1389 (Table T1). Hole U1389A was cored using the advanced piston corer (APC) to 97.2 meters below seafloor (mbsf) and then with the extended core barrel (XCB) to 354.9 mbsf. Only one piston core $(9.5 \mathrm{~m})$ was taken in Hole U1389B. Hole U1389C was cored with the APC to 95 mbsf and then with the XCB to 350 mbsf. Hole U1389D was cored with the APC to 94 mbsf to provide an additional record of the upper section at the site. Hole U1389E was drilled without coring to 335 mbsf and then cored using the rotary core barrel (RCB) to the depth objective of 990 mbsf. Downhole logging was carried out in Holes U1389A and U1389E using the triple combination (triple combo) and Formation MicroScanner (FMS)-sonic tool strings (see "Downhole logging at Site U1389"). The Versatile Sonic Imager (VSI) tool string was deployed for a vertical seismic profile (VSP) survey in Hole U1389A. Overall recovery at Site U1389 was $307.28 \mathrm{~m}$ (103.55\% recovery) with the APC, 463.93 $\mathrm{m}(90.49 \%$ recovery) with the $\mathrm{XCB}$, and $352.28 \mathrm{~m}$ (53.78\% recovery) with the RCB. The total cored interval at Site U1389 was $1463.4 \mathrm{~m}$ and total recovery was $1123.49 \mathrm{~m}(76.8 \%)$.

\section{Hole U1389A}

The APC/XCB bottom-hole assembly BHA was assembled and deployed to 651.7 mbrf. Subsequent to a $1.3 \mathrm{~h}$ survey of the seafloor, Hole U1389A was spudded with the APC at $0240 \mathrm{~h}$ on 22 December. The water depth calculated from the recovery of the first core established the seafloor at 656.2 meters below rig floor (mbrf; $644.7 \mathrm{mbsl}$ ). This was $1.3 \mathrm{~m}$ shallower than the corrected precision depth recorder depth.

Piston coring advanced Hole U1389A to the refusal depth of 99 mbsf. The average recovery for this interval was $103 \%$. Core orientation started with Core 339-U1389A-4H. Three advanced piston corer temperature tool (APCT-3) measurements were made at 33 (Core 4H), 61 (Core 7H), and 90 (Core 10H) mbsf. Nonmagnetic core barrels were utilized on all cores. XCB coring deepened the hole to a final depth of 357 mbsf by $1415 \mathrm{~h}$ on 23 December. The average recovery for the $258 \mathrm{~m} \mathrm{XCB}$ interval of the hole was $91 \%$. The total average recovery for the entire hole was $94 \%$.

\section{Holes U1389B and U1389C}

Hole U1389B was spudded at $2010 \mathrm{~h}$, but the full core barrel could not be used to ascertain the sea- floor depth. Hole U1389C was spudded with the APC at $2025 \mathrm{~h}$ and established the seafloor depth at $654.5 \mathrm{mbrf}$ (643 mbsl). Piston coring advanced to 95 mbsf. Cores were oriented starting with Core $3 \mathrm{H}$. The APCT-3 was deployed at 19 (Core 2H), 47.5 (Core $5 \mathrm{H}$ ), and 76 (Core $8 \mathrm{H}$ ) mbsf. All cores were obtained with nonmagnetic core barrels. Coring continued in Hole U1389C with the XCB, which reached the depth objective of 350 mbsf at $0815 \mathrm{~h}$ on 26 December. Recovery for the $255 \mathrm{~m}$ XCB interval of the hole was $90 \%$. The total recovery for both coring systems for Hole U1389C was 94\%. The bit was pulled free of the seafloor at $1000 \mathrm{~h}$ on 26 December, and the vessel offset $20 \mathrm{~m}$ south of the previous hole.

\section{Hole U1389D}

An additional hole was piston cored to obtain a complete section of the uppermost $\sim 100 \mathrm{~m}$ portion of the sedimentary record at Site U1389. Hole U1389D was spudded with the APC at $1120 \mathrm{~h}$, and the water depth was established at $655.5 \mathrm{mbrf}(644 \mathrm{mbsl})$. Piston coring advanced without incident to the depth objective of 94 mbsf by 1845 h. Recovery was 104\%. The cores were oriented starting with Core $3 \mathrm{H}$. Three APCT-3 measurements were made at 24.5 (Core $3 \mathrm{H}$ ), 53 (Core 6H), and 75 (Core 9H) mbsf. All cores were obtained with the nonmagnetic core barrels.

\section{Hole U1389E}

The drill string was recovered, and the bit cleared the rotary table at $2220 \mathrm{~h}$ on 26 December. The vessel offset 20 m west. A four-stand RCB BHA was made up and deployed. After the driller tagged the seafloor at $655 \mathrm{mbrf}$ (643.5 mbsl), Hole U1389E was spudded with the RCB at $0240 \mathrm{~h}$ on 27 December. We drilled without coring to $355 \mathrm{mbsf}$, where continuous rotary coring was initiated at $1830 \mathrm{~h}$. Rotary coring continued until $0845 \mathrm{~h}$ on 1 January 2012, when the hole was terminated at the depth objective of 989.9 mbsf. A total of $654.9 \mathrm{~m}$ was cored with a recovery of $54 \%$.

\section{Downhole logging at Site U1389}

On 23 and 24 December, we carried out downhole logging operations in Hole U1389A. During preparations for logging, the wiper trip found only $1 \mathrm{~m}$ of soft fill at the bottom of the hole, and the hole was filled with $112 \mathrm{bbl}$ of $10.5 \mathrm{ppg}$ mud. The open end of the pipe was placed at a logging depth of 85.7 mbsf. The triple combo tool string, composed of the natural gamma radiation (NGR), density, and resistivity tools, descended through the seafloor at $2300 \mathrm{~h}$ on 23 December and was run to the bottom of the hole 
at 1011 mbrf (355 mbsf). A short pass of $75 \mathrm{~m}$ was followed by a main pass up to the seabed. Sand-rich layers are apparent by their low gamma radiation signature. The hole was mostly in gauge but had several meter-scale washouts. The tool string was back on deck by $0140 \mathrm{~h}$.

The FMS-sonic tool string reached the bottom of the hole and made two passes, recording resistivity images of the borehole, sonic velocities, and NGR data over the entire interval. The tool string was back on deck at $0950 \mathrm{~h}$. The VSI tool string was run to conduct the VSP experiment. Marine mammal watch started at $\sim 1100 \mathrm{~h}$ on 24 December. The air guns (two-gun cluster, $7 \mathrm{mbsl}$ on the port side) were ramped up in a soft start procedure. The VSI tool started its descent in Hole U1389A at $1145 \mathrm{~h}$ and reached the bottom of the hole. Ten out of eleven stations recorded good sonic waveforms. Station spacing averaged $\sim 25 \mathrm{~m}$, and the survey itself lasted from 1300 to $1500 \mathrm{~h}$. The tool string was back on deck at $1630 \mathrm{~h}$, and logging equipment was rigged down by $1715 \mathrm{~h}$. At $1755 \mathrm{~h}$, the bit cleared the seafloor and the vessel offset $20 \mathrm{~m}$ east of Hole U1389A.

After coring operations had finalized at Hole U1389E, a wiper trip was conducted to condition the hole in preparation for downhole logging. After concluding the wiper trip, the bit was released and the hole was displaced with $375 \mathrm{bbl}$ of $10.5 \mathrm{ppg}$ logging mud. The end of pipe was positioned at 102.2 mbsf. The first log was made with the triple combo tool string, which was deployed shortly after $2400 \mathrm{~h}$ on 1 January. The tool was not able to pass a bridge or ledge at $567 \mathrm{mbsf}$. The tool was recovered at $0610 \mathrm{~h}$ after logging the hole up from $567 \mathrm{mbsf}$. The second logging experiment was made with the FMS-sonic tool string, which was also unable to penetrate deeper than 567 mbsf. The FMS-sonic was recovered at $1425 \mathrm{~h}$ after logging the upper portion of the hole.

The VSP experiment was canceled. Shortly after arriving at Site U1389, maintenance was carried out in the vessel's sea chest and bilge spaces. As part of this routine, ultrasonic thickness readings were taken on the steel plating. Evaluation of the readings indicated that some of the sea chest plating had wastage beyond acceptable limits and that several frames on the starboard side required immediate attention. Although repairs were in progress, it was felt that the sound pressure generated by the air gun during seismic profiling could subject the deteriorated sea chest to sufficiently high levels of vibration that would present a potential risk to the vessel. Therefore, VSP measurements planned for the last three sites of the expedition were canceled. The logging equipment was rigged down, the drill string was recovered, and the beacon was recalled. The vessel departed for the sixth site of the expedition at $1930 \mathrm{~h}$ on 2 January. Total time at Site U1389 was 12 days.

\section{Lithostratigraphy}

Drilling at Site U1389 penetrated a 990 m thick sedimentary section (Figs. F8, F9, F10). The shipboard lithostratigraphic program involved detailed visual assessment of grain size, sediment color, sedimentary structures, and bioturbation intensity to describe the facies and facies associations at Site U1389. Petrographic analyses of smear slides taken regularly from each hole (111 from Hole U1389A, 4 from Hole U1389B, 82 from Hole U1389C, 17 from Hole U1389D, and 136 from Hole U1389E) were used to provide detailed sediment description, identification of major components, and a more descriptive sediment classification. From Holes U1389A and U1389E, 99 samples were selected for powder X-ray diffraction (XRD) analysis of bulk mineralogy.

Total carbonate content in these cores, based on shipboard analyses, ranges from 21 to $35 \mathrm{wt} \%$. These results are consistent with abundances of biogenic carbonate and detrital carbonate estimated from smear slides, so the lithologic names determined from smear slide analyses have been used without modification through this text, the accompanying summary diagrams, and the visual core description sheets.

The sedimentary succession at Site U1389 has been classified as one major lithologic unit with five subunits (IA-IE) (Figs. F9, F10). Unit I is a Holocene-late Pliocene (3.6 Ma) sequence of calcareous mud, silty mud with biogenic carbonate, sandy mud, and silty sand with biogenic carbonate. Overall, the succession is very uniform in character, with little variation in lithology or composition. The principal changes observed are in the relative number of silty mud and sandy mud beds, as well as in the number of bi-gradational, inversely graded, and normally graded sequences. Accordingly, the unit divisions for this site have been based mainly on facies changes rather than lithologic or compositional changes.

The character of sediment physical properties, including NGR, magnetic susceptibility, color reflectance parameters, and density, records the distribution of these various lithologies and sediment components (see "Physical properties"). Characteristics of the sedimentary sequence cored at Site U1389, together with some of these additional properties, are summarized in Figure F11. 


\section{Unit I description}

Because the five subunits in Unit I have relatively similar lithologies, texture, composition, and colors, this section is organized somewhat differently than the unit descriptions in other Expedition 339 site chapters. For Site U1389, this section begins by highlighting the distinctive characteristics of each subunit. The general characteristics shared by all subunits are described subsequently, following the same format used to describe individual subunits or units at other sites.

\section{Subunit IA}

Intervals: 339-U1389A-1H-1, $0 \mathrm{~cm}$, through 33XCC; 339-U1389B-1H-1, $0 \mathrm{~cm}$, through 1H-CC, $25 \mathrm{~cm}$ (bottom of the hole [BOH]); 339-U1389C$1 \mathrm{H}-1,0 \mathrm{~cm}$, through 34X-3, $106 \mathrm{~cm} ; 339-$ U1389D-1H-1, $0 \mathrm{~cm}$, through $11 \mathrm{H}-\mathrm{CC}, 32 \mathrm{~cm}$ (BOH)

Depths: Hole U1389A $=0$ 0-302.36 mbsf, Hole $\mathrm{U} 1389 \mathrm{~B}=0-9.72 \mathrm{mbsf}(\mathrm{BOH})$, Hole U1389C $=$ 0-310.09 mbsf, Hole U1389D = 0-94.52 $(\mathrm{BOH})$

Age: Holocene-Pleistocene ( 1.2-1.6 Ma)

Overall, the dominant lithology in Subunit IA is calcareous mud (63\%) (Fig. F10). The other lithologies include silty mud with biogenic carbonate (24\%), sandy mud with biogenic carbonate (7\%), and silty sand with biogenic carbonate (6\%). Compositionally, a relatively equal contribution is made from siliciclastics (38\%), detrital carbonate (34\%), and biogenic carbonate (28\%) (Table T2). Biogenic silica is a minor constituent (1\%). Grain size in this subunit is also evenly spread between sand (31\%), silt (30\%), and clay (39\%). Although the clay size fraction is most abundant, this subunit does have the highest sand abundance in Unit I.

A downhole color change is prominent in the uppermost $2 \mathrm{~m}$ of Subunit IA, from olive-gray through dark greenish gray to dark gray. Below 15 mbsf, sediment becomes slightly more mottled in shades of green (greenish gray to dark greenish gray). In general, sediments with higher sand and/or carbonate contents have lighter colors. A distinct reddish mottled calcareous mud and a distinct greenish mottled calcareous mud also occur in discrete localities throughout the succession.

Several coarser grained lithologies form graded beds within the calcareous muds. The numbers of these graded beds are as follows: silty mud with biogenic carbonate $(n=411$; average thickness $=9 \mathrm{~cm})$, sandy mud with biogenic carbonate $(n=166$; average thickness $=4 \mathrm{~cm})$, and silty sand with biogenic carbonate $(n=106$; average thickness $=7 \mathrm{~cm})$ (Table
T3). These beds occur as normally graded, inversely graded, and bi-gradational sequences.

The most complete bi-gradational sequences coarsen upward from calcareous mud through silty mud with biogenic carbonate to silty sand with biogenic carbonate, and then fine upward to silty mud with biogenic carbonate and into calcareous mud (e.g., Fig. F12). Some of the sequences are less complete, lacking the silty sand component. Contacts between lithologies within the bi-gradational units are gradational and bioturbated. Inversely graded sequences generally coarsen upward from calcareous mud to silty mud with biogenic carbonate and then to sandy mud. In more complete inversely graded sequences, the interval grades upward into silty sand. Basal contacts are gradational or bioturbated. The upper contacts are often sharp or irregular, if not disturbed by bioturbation. These two sequence types are considered as typical contourite facies and are the most common sequences in Subunit IA $(n=177)$.

The normally graded sequences in Subunit IA $(n=$ 51) fine upward, generally from silty sand with biogenic carbonate to silty mud with biogenic carbonate and then to calcareous mud (Fig. F13; Table T3). The sequences have sharp, erosional, or irregular basal contacts with the underlying calcareous mud. However, in places the basal contacts become unclear due to bioturbation. Some of these sequences are less complete, lacking the silty sand.

\section{Subunit IB}

Intervals: 339-U1389A-34X-1, $0 \mathrm{~cm}$, through 39XCC, $39 \mathrm{~cm}$; 339-U1389C-34X-3, $106 \mathrm{~cm}$, through 38X-CC, $37 \mathrm{~cm}$; 339-U1389E-2R-1, 0 $\mathrm{cm}$, to $8 \mathrm{R}$

Depths: Hole U1389A $=303.00-350.90 \mathrm{mbsf}$ $(\mathrm{BOH})$, Hole U1389C $=310.09-347.01 \mathrm{mbsf}$ $(\mathrm{BOH})$, Hole U1389E = 335.00-387.10 mbsf

Age: Pleistocene

The dominant lithology in Subunit IB is calcareous mud, which is more abundant in Subunit IB (82\%) than in any other subunit (Table T4; Fig. F10). Other lithologies include silty mud with biogenic carbonate $(11 \%)$, sandy mud with biogenic carbonate (4\%), and silty sand with biogenic carbonate (3\%). Other than a small relative increase in the average abundance of siliciclastics (from 38\% to 45\%), little compositional difference can be determined between Subunits IA and IB (average abundances of detrital carbonate and biogenic carbonate is $31 \%$ and $24 \%$, respectively, in Subunit IB) (Table T2). The clay size fraction is more abundant (47\%) and the sand size fraction is less abundant (20\%) in Subunit IB than in 
Subunit IA, whereas the silt abundance remains similar.

Even after accounting for the difference in subunit thicknesses, the number and average thickness of silty mud beds ( $n=15$; average thickness $=9 \mathrm{~cm})$ are less than those observed in Subunit IA. The number and thickness of sandy mud beds $(n=15$; average thickness $=4 \mathrm{~cm})$ and of silty sand beds $(n=9$; average thickness $=7 \mathrm{~cm}$ ) are also lower than in Subunit IA (Table T3). This distinct change is also observed in the decrease in bi-gradational and inversely graded sequences (contourite facies; $n=9$ ) and normally graded sequences $(n=10)$.

\section{Subunit IC}

Interval: 339-U1389E-8R-1, $0 \mathrm{~cm}$, through 24RCC, $26 \mathrm{~cm}$

Depth: 387.10-548.23 mbsf

Age: Pleistocene (1.8 Ma)

The dominant lithology in Subunit IC is calcareous mud (69\%) (Table T4; Fig. F10). Minor lithologies include silty mud with biogenic carbonate $(18 \%)$ and sandy mud with biogenic carbonate $(13 \%)$, whereas silty sand with biogenic carbonate is absent. The average abundance of siliciclastic components in smear slides (56\%) is the highest observed in any subunit, with correspondingly lower abundances of detrital carbonate (27\%), and biogenic carbonate (22\%) (Table T2). Subunit IC is slightly enriched in the clay size fraction (51\%) and depleted in sand (17\%), whereas the abundance of silt remains similar to that observed in Subunits IA and IB.

The number and thickness of silty mud beds ( $n=40$; average thickness $=103 \mathrm{~cm})$ and sandy mud beds $(n$ $=37$; average thickness $=58 \mathrm{~cm}$ ) increase in Subunit IC relative to Subunit IB. Silty sand beds are rare, with only three thin to medium beds occurring (3, 17 , and $20 \mathrm{~cm}$ thick) (Table T3). This distinct facies change is also observed in the sequence types, with bi-gradational $(n=19)$ and normally graded $(n=17)$ beds becoming more abundant.

\section{Subunit ID}

Interval: 339-U1389E-25R-1, $0 \mathrm{~cm}$, through 40RCC, $15 \mathrm{~cm}$

Depth: 549.80-699.24 mbsf

Age: Pleistocene (base of subunit corresponds with the Pliocene/Pleistocene boundary)

As with Subunits IA- IC, this subunit is dominated by calcareous mud. However, the abundance of calcareous mud decreases slightly from Subunit IC to Subunit ID (from 69\% to 63\%) (Table T4; Fig. F10). The abundances of silty mud with biogenic carbonate $(19 \%)$ and sandy mud with biogenic carbonate
(16\%) increase slightly from Subunit IC, with the abundance of sandy mud with biogenic carbonate reaching its maximum for Unit I. Silty sand with biogenic carbonate is a minor contributor to Subunit ID (2\%), but even this low abundance is noteworthy compared to the absence of this lithology in Subunit IC. The average abundances of siliciclastic sediment components $(50 \%)$, detrital carbonate $(27 \%)$, and biogenic carbonate (24\%) are similar to their abundances in Subunits IA-IC (Table T2), as are the abundances of the clay (48\%), silt (29\%), and sand (17\%) size fractions.

The facies change identified in Subunit ID is a relative increase in the number and thickness of silty mud beds $(n=64$; average thickness $=150 \mathrm{~cm})$ and sandy mud beds $(n=74$; average thickness $=128$ $\mathrm{cm})$. The number of silty sand beds again remains low $(n=7$; average thickness $=14 \mathrm{~cm}$; Table T3). The increase in silty and sandy beds also corresponds with an increase in the number of bi-gradational $(n=$ $50)$ and normally graded $(n=23)$ sequences, which are more abundant than in Subunits IB and IC. This increase in silty and sandy beds, as well as in graded beds, is interpreted to record a relative increase in current activity (Figs. F9, F10).

\section{Subunit IE}

Interval: 339-U1389E-41R-1, $0 \mathrm{~cm}$, through 70R-1, $83 \mathrm{~cm}(\mathrm{BOH})$

Depth: 703.60-982.73 mbsf (BOH)

Age: Pliocene (recovered base of subunit is $~ 3.6$ Ma)

As with the overlying succession, this subunit is dominated by calcareous mud, although there is relatively less mud (50\%) and more silty mud with biogenic carbonate $(34 \%)$ than in any other subunit (Table T4; Fig. F10). The abundance of sandy mud with biogenic carbonate is the same as in Subunit ID, whereas silty sand with biogenic carbonate is absent from Subunit IE. The average abundances of siliciclastic components (50\%), detrital carbonate (24\%), and biogenic carbonate (23\%) are similar to those in the overlying units (Table T2), as are the average abundances of the clay (50\%), silt (31\%), and sand (19\%) size fractions.

The observed facies changes identified in Subunit IE are a decrease in the number and thickness of silty mud beds $(n=43$; average thickness $=144 \mathrm{~cm})$, a significant decrease in the number and thickness of sandy mud beds ( $n=22$; average thickness $=76 \mathrm{~cm}$ ), and the absence of silty sand beds (Table T3). This decrease in the importance of silty and sandy beds also corresponds with a decrease in the number of bi-gradational sequences $(n=22)$ and the absence of normally graded sequences. 


\section{Lithologic characteristics}

The sedimentary succession at Site U1389 has been classified as one major lithologic unit with five subunits (IA-IE) (Figs. F9, F10). Unit I is a $\sim 990 \mathrm{~m}$ thick Holocene-Pliocene ( $3.6 \mathrm{Ma})$ sequence of calcareous mud $(61 \%)$, silty mud with biogenic carbonate (24\%), sandy mud with biogenic carbonate (11\%), and silty sand with biogenic carbonate (4\%) (Table T4). The silty and sandy lithologies are generally present as bi-gradational, normally graded, or inversely graded sequences within the calcareous mud. The division of Unit I into five subunits was based on subtle changes in the relative abundances of the different lithologies and in the facies characteristics of the sandy and silty lithologies.

\section{Texture}

On average, sediment is fine grained through most of Unit I; the average grain size is clay in $45 \%$ of the section and silt in $32 \%$ of the section (Table T2). The intervals of sandy mud and silty sand with biogenic carbonate have an average grain size from very fine to fine sand $(24 \%)$, with a maximum grain size of medium sand. Silty and sandy units generally are poorly sorted, with detrital siliciclastic grains that are subrounded to rounded. Detrital carbonate grains are generally subrounded to subangular, many with abraded margins indicative of reworking.

\section{Composition}

All lithologies in Unit I are similar in composition, with only subtle changes in abundances between the subunits (Tables T2, T4). Accordingly, the composition of Unit I is described here, and the subtle differences are identified for each subunit below. Unit I is dominated by terrigenous components, including siliciclastics (44\%, including quartz, feldspars, heavy minerals, clay minerals, and volcanic glass), and detrital carbonate (30\%). Biogenic components (25\%) are dominated by calcareous nannofossils, with rare to common foraminifers (Table T2). Biogenic silica components are rare $(<1 \%)$ but when present include sponge spicules and fragmented radiolarians. No discrete ash or dust layers and no dropstones were observed. Authigenic components, such as pyrite (usually classified as opaque mineral grains) and dolomite, are also present in minor amounts $(<1 \%)$ throughout Unit I. Some dolomite grains are subangular, which may indicate a detrital origin. Glauconite grains are also present throughout Unit I $(<1 \%)$. Both glauconite and dolomite are generally more abundant in the silty sand beds.

\section{Bulk mineralogy}

Interpretations of bulk mineralogy are based on XRD scans of pressed powders without any rescans after glycolation. The principal minerals identified include quartz, plagioclase, calcite, dolomite, and clays (Fig. F14; Tables T5, T6). The peak intensity of quartz in Unit I varies between 23,000 and 32,000 counts, with the highest counts in Subunits IA and ID. The peak intensity of calcite varies between 12,700 and 17,000 counts in Unit I, with the highest intensity in Subunit IE and no clear trend with lithology. The intensity of the illite diffraction peak ranges between 3,000 and 4,300 counts, with the greatest intensities in Subunits IA and IE. Other clay minerals (chlorite, kaolinite, and smectite) show lower intensities and very little variation throughout Unit I. Plagioclase tends to be slightly more abundant in Subunits IA and ID. Sediment in Subunits IA and IB contains slightly more hornblende than in the other units. Overall, Subunit IA shows the greatest variability in mineral peak intensities, followed by Subunits ID and IE, but the subunits have a relatively uniform composition throughout.

\section{Faunal elements and ichnofossils}

Macrofossil fragments and some nearly whole specimens occur throughout Unit I. Recognizable fragments include gastropods, bivalves, echinoderms, cold-water corals, and Arenaria (Figs. F15, F16, F17). Bioturbation and burrows are also common throughout, usually indicated by diffuse centimeter-scale mottling and millimeter-scale pyritic burrow fills. Black iron sulfide mottling is also common in the calcareous mud. Discrete burrows and recognizable ichnofossils are rare, but include Chondrites, Zoophycos, Planolites, and Spirophyton (Figs. F18, F19, F20). The bioturbation index for all of Unit I ranges from sparse to slight.

\section{Discussion}

Overall, the sedimentary succession recovered at Site U1389 is very uniform in character, with little variation in lithology or composition. The principal changes observed are in the relative abundance of silty mud and sandy mud beds, as well as in the number of bi-gradational, inversely graded, and normally graded sequences. Accordingly, the subunits at this site have been defined primarily on the basis of facies changes, rather than lithologic or compositional changes.

Unit I is interpreted as the record of a contouritedominated depositional system, at least for Subunits 
IA-IC, based on several lines of evidence. Most compelling is the fact that the site presently is located on a bathymetric high surrounded by deeply erosional contourite channels (García et al., 2009) on three sides and a bathymetric depression to the northwest (Fig. F1). Furthermore, the site lies directly under the influence of the lower core of MOW and has no obvious connection with downslope (turbidite) channels. There seems to be little evidence of a direct turbidity current input and almost no possibility that turbidity currents would have deposited thick, graded beds at Site U1389, at least in the recent past (i.e., Subunits IA- IC). Lithologic characteristics further support a contourite interpretation, including

- Extreme uniformity of composition for both silt/ sand- and mud-rich lithologies,

- Organization of these lithologies into bi-gradational sequences with a dominance of gradational contacts and extensive burrow mottling,

- Inversely graded sequences representing truncated contourites (top-cut-out contourites),

- Normally graded sequences also representing truncated contourite successions (base-cut-out contourites, rather than turbidites, as explained in greater detail below), and

- Evidence that bioturbation has been continuous throughout deposition.

Despite their grading and typically sharp basal contacts, the normally graded sequences are interpreted as truncated contourite deposits, rather than turbidites, based on the following criteria (after Faugères and Mulder, 2011):

- Abundant bioturbation throughout, compared with fine-grained turbidites, in which bioturbation is generally restricted to the uppermost parts of the deposits;

- Poor preservation of sedimentary structures, caused by the intensity of bioturbation. Such sedimentary structures are generally well preserved in fine-grained turbidites; and

- Irregular vertical textural variation and truncated sections caused by current velocity changes.

Truncation of the idealized bi-gradational contourite sequences is common as a result of changes in current velocity, producing incomplete sequences and locally sharp or irregular erosional contacts (Faugères and Mulder, 2011; Stow and Faugères, 2008). Inversely graded sequences occur where there is longterm increase in mean current velocity followed by a rapid decrease in velocity. By contrast, normally graded sequences occur where current velocity has increased sufficiently to cause erosion into the underlying silty mud contourite, leaving a sharp-based sandy contourite directly overlying a muddy contourite. Long-term fluctuations in flow velocities may produce "stacked sequences," where several partial or truncated sequences directly overlie each other. This characteristic is well developed at Site U1389.

Subunit IB is more difficult to understand, largely because core recovery in this interval $(\sim 30 \%)$ is markedly lower than in the overlying succession. Two possible interpretations are (1) the recovered sediment, which is mainly mud rich, is representative of all of Subunit IB, so that Subunit IB may record a phase when bottom currents were less intense, depositing only muddy and silty contourites interbedded with some hemiplegic material, or (2) the $70 \%$ unrecovered section is, in fact, relatively sand/silt rich, indicative of relatively higher current velocities. The slight relative increase in siliciclastic components in the sediments of Subunit IB (Table T2) may also indicate that the sediment in this subunit has a more complex composition, with a more diverse sediment supply under higher current velocities. Downhole logging results strongly support the interpretation that the unrecovered sediment is relatively sand/silt rich. This interpretation is further supported by marked changes in interstitial water geochemistry, from which we would infer a lateral fluid conduit at approximately this level, aided by the presence of the coarser grained, but unrecovered, lithologies.

Preliminary correlation with other sites suggests that Subunits IA- IC at Site U1389 correspond to Subunits IA-IC at Site U1386 and the informal subdivisions of $1 \mathrm{~A}-1 \mathrm{C}$ at Site U1387. Subunit ID is missing from Sites U1386 and U1387 because of the presence of an extensive hiatus. Subunit IE is equivalent in age with Unit II at Sites U1386 and U1387, although the lithologies and inferred transport processes are quite different.

\section{Biostratigraphy}

The sedimentary succession at Site U1389 dates from the Holocene to the late Pliocene (Fig. F21; Table T7), with the base age of Hole U1389E estimated at younger than $3.7 \mathrm{Ma}$. The samples are rich in planktonic and benthic foraminifers as well as calcareous nannofossils and ostracods. Only Samples 339U1389A-35X-CC and 36X-CC and 339-U1389C-36XCC from a sandy horizon were barren of calcareous nannofossils and planktonic foraminifers but contained a few poorly preserved benthic foraminifers. All calcareous microfossils are, in general, moderately to well preserved. Pteropod fragments are more common than at any of the previous sites and occur in nearly all samples from Cores $1 \mathrm{H}$ through $3 \mathrm{H}$ of 
Holes U1389A-U1389C (Table T8) and occur sporadically in the older sediment (Samples 339-U1389C28X-CC and 339-U1389E-25R-CC, 26R-CC, 28R-6, 33R-CC, and 43R-CC.

Pollen and spores are abundant in the 16 samples analyzed in Holes U1389A and U1389E, ranging from $\sim 8,000$ and 49,000 grains $/ \mathrm{cm}^{3}$, excluding the lowest sample, which contains $\sim 2,000$ grains $/ \mathrm{cm}^{3}$. Pollen and spore concentrations are highest at the uppermost part of the site (Fig. F22). These values are similar to those found at Sites U1386 and U1387. Preservation of grains is good to poor in Hole U1389A and moderate to poor in Hole U1389E. The proportion of unidentifiable grains progressively increases downhole, as is the case at Site U1387. Microcharcoal particles and dinocysts were also observed.

The sedimentation rates, estimated based on the calcareous nannofossil and planktonic foraminifer bioevents (Table T7), agree well with paleomagnetic datums for the Olduvai Subchron and the Gauss/ Matuyama boundary (Fig. F21; see also "Paleomagnetism"). Sedimentation rates decrease downhole and can be divided into four intervals, one of which indicates a probable hiatus. During the youngest period (0-0.46 Ma), a rate of $\sim 40 \mathrm{~cm} / \mathrm{k} . \mathrm{y}$. was recorded, preceded by a rate of $\sim 30 \mathrm{~cm} / \mathrm{k} . \mathrm{y}$. between 0.46 and $2.09 \mathrm{Ma}$.

The third sedimentation rate interval is bracketed by two planktonic foraminifer events, the first occurrence (FO) of Globorotalia inflata at $2.09 \mathrm{Ma}$ and the last occurrence (LO) of Globorotalia puncticulata at $2.41 \mathrm{Ma}$. Sedimentation rate in this interval is $\sim 5$ $\mathrm{cm} / \mathrm{k} . \mathrm{y}$., a substantial decrease from the values above and below. This unusually low value and the consistency in the values above and below this interval (Fig. F21) indicate the presence of a probable hiatus of $<0.3 \mathrm{~m}$.y. duration. No support for the existence of a hiatus can be given from the calcareous nannofossil data (see below). On the other hand, the succession from $G$. puncticulata to G. inflata with a gap of globorotaliids of this lineage in between (Core 339-U1389E-34R; Table T9) is similar to that recorded in the Mediterranean (Hilgen, 1991; Lourens et al., 2004). Distinguishing between a decrease in sedimentation rate and an hiatus is currently not possible.

For the deepest part of Site U1389, between 2.41 and $<3.7 \mathrm{Ma}$, the estimated sedimentation rate is $\sim 25$ $\mathrm{cm} / \mathrm{k} . \mathrm{y}$.

\section{Calcareous nannofossils}

We examined all core catcher samples from Holes U1389A, U1389B, U1389C, and U1389E for calcare- ous nannofossil biostratigraphy. Additionally, selected samples from Holes U1389A, U1389B, and $\mathrm{U} 1389 \mathrm{E}$ were analyzed in order to constrain biohorizons, paying attention only to marker species. Calcareous nannofossil assemblages are abundant and the preservation is good to moderate, with weak dissolution in some samples (Table T10). Small placolith species $(<3 \mu \mathrm{m})$ dominate most of the assemblages.

In total, 12 Quaternary and Neogene nannofossil datums defined and/or calibrated by Raffi et al. (2006 and references therein) and Flores et al. (2010) were identified in all holes (Table T7).

The change in abundance of large Emiliania huxleyi $(>4 \mu \mathrm{m})$ that characterizes Termination 1 in mid- to low-latitude water masses in the Atlantic (Flores et al., 2010) was recorded between Samples 339U1389A-1H-2, $75 \mathrm{~cm}$, and $1 \mathrm{H}-3,75 \mathrm{~cm}(2.25-3.75$ mbsf); between the top of Core 339-U1389B-1H and Sample 1H-CC (0-9.72 mbsf); and between the top of Core 339-U1389C-1H and Sample 1H-CC (0-9.74 mbsf), making it possible to distinguish the onset of the Holocene in all three holes.

The FO of E. huxleyi (0.26 Ma), which marks the base of Zone NN21, was placed between Samples 339U1389A-11H-2, $75 \mathrm{~cm}$, and $11 \mathrm{H}-3,75 \mathrm{~cm}(91.96-$ $93.37 \mathrm{mbsf})$ and between 339-U1389C-12X-CC and 13X-CC (111.64-122.26 mbsf).

The LO of Pseudoemiliania lacunosa (0.46 Ma), considered a globally synchronous event that defines the top of Zone NN19, occurs between Samples 339U1389A-24X-2, $74 \mathrm{~cm}$, and 24X-3, $107 \mathrm{~cm}$ (208.73$210.56 \mathrm{mbsf}$ ), and 339-U1389C-23X-CC and 24X-CC (211.52-221.12 mbsf).

The LO of Reticulofenestra asanoi (0.90 Ma) was placed between Sample 339-U1389A-36X-1, $83 \mathrm{~cm}$, and 37X-1, $115 \mathrm{~cm}$ (322.63-332.55 mbsf), and 339U1389C-36X-1, $80 \mathrm{~cm}$, and 36X-1, $134 \mathrm{~cm}$ (326.9$327.44 \mathrm{mbsf})$. The FO of $R$. asanoi (1.07 Ma), another significant event for the Pleistocene, was recorded between Sample 339-U1389E-5R-2, $75 \mathrm{~cm}$, and 5R-3, $75 \mathrm{~cm}$ (360.65-362.15 mbsf). To define these biohorizons, we considered specimens of $R$. asanoi $\geq 6 \mu \mathrm{m}$ in size.

The LO of large Gephyrocapsa spp. (>5.5 $\mu \mathrm{m} ; 1.24$ $\mathrm{Ma}$ ) and the LO of Helicosphaera sellii were recorded between Samples 339-U1389E-7R-1, $5 \mathrm{~cm}$, and 8R-1, $89 \mathrm{~cm}$ (377.66-387.99 mbsf). The FO of large Gephyrocapsa spp. ( $>5.5 \mu \mathrm{m} ; 1.61 \mathrm{Ma})$ was identified between Samples 339-U1389E-17R-3, $77 \mathrm{~cm}$, and 17R$4,77 \mathrm{~cm}$ (477.07-478.57 mbsf). The LO of Calcidiscus macintyrei (1.66 Ma) was identified between Samples 
339-U1389E-20R-CC and 21R-CC (510.09-515.65 mbsf).

The LO of Discoaster brouweri defines the boundary between Zones NN18 and NN19. In Hole U1389E, the record of this species is scarce and discontinuous between Samples 339-U1389E-28R-6, $5 \mathrm{~cm}$, and 35RCC (586.78-653.74 mbsf), preventing accurate placement. Moreover, these sections are characterized by the presence of some slumped intervals (e.g., Core 339-U1389E-28R; see "Lithostratigraphy") that can include reworked species.

Based on the planktonic foraminifer record, the possible existence of a hiatus is suggested between the FO of G. inflata (2.09 Ma) and the LO of G. puncticulata (2.41 Ma). The absence of accurate calcareous nannofossil bioevents in this interval cannot contribute to confirm the hiatus.

The LO of Discoaster pentaradiatus, marking the boundary of Zones NN17 and NN18, was identified between Samples 339-U1389E-37R-CC and 38R-CC (674.25-681.98 mbsf), indicating an early Pleistocene age.

The LO of Discoaster surculus (2.53 Ma) is used here to approximate the Pleistocene/Pliocene boundary between Samples 339-U1389E-38R-CC and 39R-CC (681.98-693.70 mbsf).

The oldest event identified at this site is the LO of Discoaster tamalis (2.8 Ma) between Samples 339U1389E-44R-4, $5 \mathrm{~cm}$, and 45R-CC (737.96-751.54 mbsf). From this depth to the base of Hole U1389E, the calcareous nannofossil assemblage is typical of the upper Pliocene, dominated by abundant small Gephyrocapsa, small and medium Reticulofenestra, and regular presence of $P$. lacunosa. The records of Sphenolithus spp. and Reticulofenestra pseudoumbilicus $(>7 \mu \mathrm{m})$, which are intermittent, were interpreted as reworked. Thus, the base age of Hole U1389E is younger than the LO of these species at 3.70 and $3.82 \mathrm{Ma}$, respectively.

\section{Planktonic foraminifers}

Samples from all core catchers were analyzed in Holes U1389A-U1389C and U1389E (Tables T8, T9). No samples were taken from Hole U1389D. In Holes U1389A and U1389E, additional samples from within the cores were studied to better constrain the Holocene/Pleistocene boundary (Hole U1389A) and the position of some planktonic foraminifer events (Hole U1389E). Planktonic foraminifers are moderately to well preserved, except for Samples 339U1389A-32X-CC, 339-U1398C-38X-CC, and 339U1389E-22R-CC. Samples 339-U1389A-35X-CC and 36X-CC and 339-U1389C-36X-CC are devoid of planktonic foraminiferal shells, and Sample 339U1389C-37X-CC is almost barren.

The assemblages are composed of both warm- and cold-water species. Significant constituent species of the cold-water assemblage are Neogloboquadrina pachyderma (sinistral) and Globigerina bulloides. On the other hand, the warm-water assemblage is characterized by the dominance of Globigerinoides ruber, Globigerinoides trilobus, Globigerinoides sacculifer, and Sphaeroidinellopsis seminulina, with the latter three species becoming more important in the lower Pleistocene and upper Pliocene. The dominance of $G$. inflata in the Pleistocene and G. puncticulata in the Pliocene sediment, as well as the presence of $N$. pachyderma (dextral) in the assemblages, characterizes transitional conditions from temperate to cool subtropical water masses. Other species commonly associated with the transitional water mass assemblage are Globorotalia truncatulinoides, Globorotalia crassaformis s.l., and Globogerinita glutinata.

As for the previous sites, Neogloboquadrina atlantica (dextral) was observed in samples from the midPleistocene of Hole U1389E, with a continuous presence between Samples 339-U1389E-25R-CC and 9R$\mathrm{CC}$ and a single earlier occurrence in Sample 31RCC.

The occurrence of $N$. atlantica (sinistral) between Samples 339-U1389E-35R-CC and 40R-CC and in Sample 51R-1, 59-61 cm, was too rare to define its $\mathrm{LO}$ as a biohorizon. Likewise, Globorotalia miocenica was observed only in Samples 52R-5, 59-61 cm, and $64 \mathrm{R}-1,59-61 \mathrm{~cm}$, and was thus too rare to be used as biostratigraphic datum.

In the upper Pliocene samples, G. puncticulata is often present as the more inflated Globorotalia bononiensis morphotype).

Evidence of reworked foraminifers was only found in some samples and always restricted to a few specimens: one specimen of Globorotalia margaritae in Sample 339-U1389E-35R-CC; one or two specimens of G. puncticulata in Samples 23R-CC, 24R-CC, and 25R-CC; and one specimen of $S$. seminulina in Samples 15R-CC, 23R-CC, and 29R-CC.

In Holes U1389A-U1389C, no planktonic foraminifer event was observed because the holes only contain mid- to upper Pleistocene sediments (Fig. F21). However, 10 planktonic foraminifer events were recognized in Hole U1389E, spanning from the upper Pliocene $(<3.81 \mathrm{Ma})$ to the lower Pleistocene (Table T7).

The top of the paracme of $N$. pachyderma (sinistral), defined by the reappearance of this species in marine isotope Stage 38 (1.21 Ma; Lourens et al., 2004; 
Raymo et al., 1989; Sierro et al., 2009), was observed between Sections 339-U1389E-6R-1 and 6R-CC (368.62-369.54 mbsf).

The bottom of the paracme of $N$. pachyderma (sinistral) is also poorly constrained because the species is absent from Samples 339-U1389E-6R-CC through 11R-4 (369.54-421.80 mbsf) and very rare in Section 12R-6 (433.73 mbsf). We consequently placed this event at this depth, although a higher resolution analysis is needed to refine its position.

The FO of $G$. inflata was identified between Samples 339-U1389E-33R-1, 59-61 cm, and 33R-3, 59-61 cm (627.21-630.21 mbsf). The event is very reliable because this species is very abundant and constantly present in the North Atlantic since its FO. The age of this event is $2.09 \mathrm{Ma}$ (Lourens et al., 2004) and was recorded for the first time during this expedition because in the previous sites either the recovered sediments were younger in age or the FO of $G$. inflata was associated to a significant hiatus.

Below the FO of G. inflata, globorotaliids of this lineage are absent (Table T9) until the regularly observed specimens of $G$. puncticulata between Samples 339-U1389E-34R-CC and 35R-1, 59-61 cm (645.02$646.61 \mathrm{mbsf})$, in which the LO of this species was recorded. This event is also very reliable because this species, which is very abundant in the Mediterranean and northeast Atlantic until 2.41 Ma (Lourens et al., 2004), completely disappeared from this region.

G. crassaformis varies from rare to common in the lower Pleistocene. With the exception of some short increases of dextral specimens, G. crassaformis is dominantly sinistral in the upper part of the hole. A pronounced change from sinistral to dextral was observed, however, between Samples 339-U1389E-47RCC and 48R-CC (764.48-772.41 mbsf). This event was identified in the Mediterranean (Zachariasse et al., 1989) and has been astronomically dated at 2.99 Ma (Berggren et al., 1995; Lourens et al., 2004; L.J. Lourens, pers. comm., 2012) (Table T7).

The LO of Dentoglobigerina altispira (3.17 Ma) was observed between Samples 339-U1389E-54R-CC and 55R-1, 29-31 cm (830.21-838.21 mbsf). In general, this species is rare in Hole U1389E. Support for placing the LO at this level at Site U1389 comes from evidence in the Mediterranean. There, in the Punta Piccola section in Sicily, the LO of D. altispira was found immediately above the LO of $S$. seminulina during an interval of dextral coiling G. crassaformis (Zachariasse et al., 1989). Although the LO of D. altispira coincides with the LO of S. seminulina in our low-resolution study at Site U1389, both occurred during an in- terval with dominantly dextral coiling $G$. crassaformis (Table T9).

The LO of S. seminulina (3.19 Ma; Lourens et al., 2004) was found at the same level as the LO of D. altispira (i.e., between Samples 339-U1389E-54R-CC and 55R-1, 29-31 cm; 830.21-838.21 mbsf).

The top of the temporal disappearance of G. puncticulata (3.31 Ma; Lourens et al., 2004) was recorded between Samples 339-U1389E-57R-3, 58-60 cm, and 57R-5, 59-61 cm (860.70-863.74 mbsf).

The bottom of the temporary disappearance of $G$. puncticulata (3.57 Ma; Lourens et al., 2004), was identified between Samples 339-U1389E-65R-1, 59-61 $\mathrm{cm}$, and 64R-6, 49-54 cm (932.13-934.61 mbsf).

Sample 339-U1389E-70R-CC (982.78 mbsf), at the base of Hole U1389C, contains many specimens of G. puncticulata but no G. margaritae, indicating that the age of this sediment is younger than $3.81 \mathrm{Ma}$ (i.e., the age of the LO of G. margaritae in the Mediterranean and northeast Atlantic [Lourens et al., 2004]). The presence of some specimens of Globorotalia hirsuta (dextral) in this sample suggests that this sediment was deposited immediately above the LO of $G$. margaritae, in accordance with observations in equivalent sections offshore northern Morocco (Sierro, unpubl. data).

\section{Benthic foraminifers}

All core catcher samples from Holes U1389A and U1389E were analyzed for benthic foraminiferal assemblages (Table T11). Additionally, Samples 339U1389B-21X-CC through 38X-CC were evaluated for the "Stilostomella extinction." As with previous sites, the abundance and preservation of benthic foraminifers are related to lithology, and major changes in benthic foraminiferal assemblages correspond well with lithologic units. Benthic foraminifers are generally abundant. Moderately to well preserved assemblages preferentially occur in the upper and lower portions of the succession, whereas moderate to poor preservation occurs in Samples 339-U1389A-35X-CC through 39X-CC and 339-U1389E-22R-CC through 50R-CC.

Based on the revealed benthic foraminiferal assemblages, three intervals can be distinguished in the succession that correspond well to lithologic Subunits 1A-1E (see "Lithostratigraphy"):

1. The interval between Samples 339-U1389A-1HCC and 34X-CC is characterized by benthic assemblages composed of Brizalina, Bulimina, Cassidulina, Melonis, and Uvigerina species that characterize environments with increased organic matter flux and reduced ventilation (van Mork- 
hoven et al., 1986; Leckie and Olson, 2003; Murray, 2006). Occasional peaks in Cibicidoides spp. record episodes of increased bottom water ventilation (e.g., Samples 339-U1389A-22X-CC and $31 \mathrm{X}-\mathrm{CC})$. Overall, these assemblages are very similar to those from Pleistocene contourite deposits at other sites. The "epibenthos group," suggested as an indicator for MOW intensity in the area (Schönfeld, 1997, 2002; Schönfeld and Zahn, 2000), shows low abundances of $<5 \%$. However, Trifarina angulosa, which is also related to strong bottom currents, commonly shows elevated abundances.

2. Between Samples 339-U1389A-35X-CC and 39XCC and 339-U1389E-2R-CC and 39R-CC, the abundance of Cibicidoides spp. generally increases, whereas the taxa characteristic of the first interval decrease, especially Uvigerina. Transport from the shelf is increased during this interval, corresponding to the increasing amount of turbiditic layers in this interval (see "Lithostratigraphy"). It can be noted that the deep-infaunal foraminifer Globobulimina affinis that commonly occurs in dysoxic deep-sea environments was observed frequently in this interval. This species is able to process low-quality organic matter more efficiently than other foraminifers; thus its occurrence might also reflect organic matter input from the shelf. The epibenthos group shows increased abundances, mainly caused by the more frequent Cibicides lobatulus (mainly in Samples 339-U1389A-37X-CC and 339-U1389E-18R-CC). In parallel, the abundance of Trifarina spp. decreases compared to its abundance in Assemblage 1.

Within this interval, the first appearance of $\mathrm{Hya}$ linea balthica, an indicator for cold-water masses (Bayliss, 1969; van Morkhoven et al., 1986), was recorded between Core 339-U1389E-13R-CC and Section 14R-CC shortly after the Mid-Pleistocene Transition. This pattern is very similar to previous Sites U1386 and U1387 and corresponds well with Mediterranean records. It also coincides with the disappearance of Siphonina tubulosa.

3. Samples 339-U1389E-40R-CC through 70R-CC yield an assemblage of Cibicidoides, Melonis, Brizalina, and Uvigerina that shows similarities to Pliocene sediment at Sites U1386 and U1387. Cassidulina laevigata/teretis, commonly occurring in boreal waters of the North Atlantic during the middle-late Pliocene and the Pleistocene, becomes rare in this interval. In parallel, the abundance of $S$. tubulosa increases and peaks between Samples 339-U1389E-55X-CC and 70X-CC. This epifaunal species has been described from warm and oxygen-depleted, upper-middle bathyal en- vironments (e.g., Szarek et al., 2007). Thus, the inverse trends in C. laevigata/teretis and S. tubulosa are potentially related to the mid-Pliocene climate optimum. The epibenthos group consists of C. lobatulus and Planulina spp. and shows an average abundance of $\sim 5 \%$.

The Stilostomella extinction event cannot be used as a reliable biostratigraphic datum at Site U1389. Nodosariids, pleurostomellids, and stilostomellids occur commonly between Samples 339-U1389E-5R-CC and 70R-CC. Above this level, individual shells have been identified in Samples 339-U1389A-39X-CC, 37X-CC, and 19X-CC. Hole U1389C shows no occurrences in the studied interval (Sections 339-U1389C$21 \mathrm{X}-\mathrm{CC}$ through $38 \mathrm{X}-\mathrm{CC}$ ). The comparison with the age constraints from calcareous nannoplankton and paleomagnetic measurements suggests that the extinction occurs 200-300 k.y. earlier at this site compared to the other sites and previous studies (0.580.7 m.y.) (Hayward, 2002; Kawagata et al., 2005). The factors responsible for this diachroneity remain uncertain.

\section{Ostracods}

Ostracods were examined from the uppermost nine core catcher samples of Hole U1389A (4.25-81 mbsf) and are most abundant in Samples 339-U1389A-1HCC through 3H-CC. Diversity is relatively high, with 36 genera recognized (Table T12). The overall ostracod assemblage is composed of a mix of upper bathyal (i.e, Cytheropteron, Argilloecia, Krithe, Cytherella, Henryhowella, Pseudocythere, and Parakrithe) and circalittoral (i.e., Paradoxostoma, Semicytherura, Loxoconcha, Aurila, Buntonia, Pterigocythereis, Callistocythere, Hiltermannicythere, Urocythereis, Xestoleberis, Caudites, and Leptocythere) taxa (Carbonel, 1985; Ruiz et al., 1997, 2008). Notably, Sample 339-U1389A-1H$\mathrm{CC}$ also contains single specimens of freshwater genera Ilyocypris and Potamocypris (Ruiz et al., 2000; Alvarez Zarikian et al., 2008; Faranda and Gliozzi, 2008). The mix of bathyal, shelf, and littoral taxa in the youngest part of the record suggests that estuarine sediments can be transported today by river plumes far into the Gulf of Cádiz.

\section{Palynology}

Seven samples from Hole U1389A (Samples 1H-CC, 6H-CC, 12X-CC, 18X-CC, 25X-CC, 31X-CC, and $37 \mathrm{X}-\mathrm{CC}$ ) and nine samples from Hole U1389E (Samples 4R-CC; 10R-CC; 16R-1, 0-5 cm; 22R-CC; 28R-6, 0-5 cm; 32R-CC; 41R-CC; 51R-CC; and 61R-1, 0-5 $\mathrm{cm})$ were analyzed. The lithology of these samples varies from clay to silty sand, and no correlation was observed between the degree of preservation and the nature of the sediment. Good, moderate, and poorly 
preserved pollen grains were found in clay sediment. Pinus is well represented in the upper $400 \mathrm{~m}$ of the sequence, with the maximum abundance in Sample 339-U1389A-12X-CC (Fig. F22; Table T13), and is virtually absent below this level (Samples 339U1389E-16R-1, 0-5 cm; 22R-CC; 28R-6, 0-5 cm; 32RCC; 41R-CC; 51R-CC; and 61R-1, 0-5 cm), although some of the corroded pollen of conifers likely belong to the Pinus genus. The same feature is observed at the previous sites and indicates an age older than 1.6 Ma.

The pollen record covering the last $1.7 \mathrm{~m}$.y. reflects the alternating dominance of the four main plant ecological groups that characterize this region, Pinus, Mediterranean forest, semidesert, and grasslands, as already documented at the previous sites (see "Biostratigraphy" in the "Site U1385," "Site U1386," and "Site U1387" chapters [Expedition 339 Scientists, 2013c, 2013d, 2013e]). Samples below 600 mbsf, dated older than $2 \mathrm{Ma}$, have the highest unidentifiables/total pollen and spores ratios. Samples 339U1389E-28R-6, 0-5 cm, 32R-CC, 41R-CC, and 51RCC are dominated by the pollen of Taraxacum-type, which is very resistant to corrosion and, additionally, easy to identify when damaged. This pollen morphotype, associated with steppe assemblages in well-preserved pollen samples, is generally overrepresented in pollen assemblages that are severely corroded, such as those observed in Greek Holocene offshore sediments (Bottema, 1990). In contrast, Sample 339-U1389E-61R-1, 0-5 cm, is dominated by corroded pollen grains of conifers. High proportions of unidentifiable pollen of conifers are a common feature in Pliocene sequences of southwestern Iberia (Jiménez-Moreno et al., 2010). The replacement of the highest proportions of Taraxacum-type pollen by the highest ratio of corroded conifers pollen occurs at this site below $820 \mathrm{mbsf}$, dated at $\sim 3.31 \mathrm{Ma}$. The same feature is recorded at Site U1387 below 700 mbsf and dated older than 4.5 Ma.

\section{Paleomagnetism}

Paleomagnetic investigation of the 159 APC, XCB, and RCB cores (excluding 1 wash core and 10 short $[<50 \mathrm{~cm}]$ cores from Hole U1389E) collected at Site U1389 included the measurement of magnetic susceptibility of whole-core and archive-half split-core sections and the natural remanent magnetization (NRM) of archive-half split-core sections. NRM was measured before and after alternating field (AF) demagnetization with $20 \mathrm{mT}$ peak fields for all studied cores of the site. The FlexIt tool was used in an attempt to orient 23 cores from the APC sections in Holes U1389A, U1389C, and U1389D starting with
Core $4 \mathrm{H}$. However, the tool failed to properly orient the cores and the corrected magnetic declination is directed toward $\sim 180^{\circ}$ instead of $0^{\circ}$. The results of this attempt are therefore not reported. Stepwise AF demagnetization of eight selected discrete samples was performed at successive peak fields of $0,5,10$, $15,20,25,30,35,40,45,50,55,60,70$, and $80 \mathrm{mT}$ to verify the reliability of the split core measurements and to determine the magnetostratigraphy in some of the strongly overprinted and disturbed XCBand RCB-cored sections. We processed data extracted from the Laboratory Information Management System database by removing all measurements collected from disturbed and void intervals, which are listed in Table T14 (see "Stratigraphic correlation"), and all measurements that were made within $10 \mathrm{~cm}$ of the section ends, which are slightly biased by measurement edge effects. The processed NRM inclination, declination, and intensity data after $20 \mathrm{mT}$ peak field AF demagnetization are listed in Tables T15, T16, T17, T18, and T19.

\section{Natural remanent magnetization and magnetic susceptibility}

The intensity of NRM after $20 \mathrm{mT}$ demagnetization is similar in magnitude in the overlapping parts of Holes U1389A through U1389E, ranging from $\sim 10^{-5}$ to $\sim 10^{-2} \mathrm{~A} / \mathrm{m}$ (Fig. F23, third panel). The uppermost $\sim 80$ mbsf exhibits the highest intensities, on the order of $10^{-2} \mathrm{~A} / \mathrm{m}$, with a mean of $\sim 0.01 \mathrm{~A} / \mathrm{m}$. In the XCB section between 80 mbsf and $185 \mathrm{mbsf}$, NRM intensities are variable (mean value is about $0.007 \mathrm{~A} / \mathrm{m}$ ) but generally lower than that in the uppermost part of the section. With the exception of a few intervals, sediment below $\sim 185$ mbsf exhibits the lowest intensities (mean value is about $0.002 \mathrm{~A} / \mathrm{m}$ ).

Despite the coring disturbance and drill string overprint in the XCB- and RCB-cored sections, a relatively stable magnetic component was preserved in sediment from all holes, allowing for the determination of magnetic polarity for most parts of the recovered sediments. A magnetic overprint with steep, positive inclinations, which was probably acquired during drilling, was usually removed by up to $20 \mathrm{mT}$ peak field AF demagnetization (Fig. F24). The XCB sections of Holes U1389A and U1389C frequently contain drilling biscuits surrounded by as much disturbed material as intact material, strongly compromising the quality of the resulting paleomagnetic data. The RCB cores from Hole U1389E exhibit a relatively well preserved magnetic polarity record down to the base of the hole at $~ 990$ mbsf.

The AF demagnetization behavior of four discrete samples from normal and reversed polarity intervals 
is illustrated in Figure F24. All samples exhibit a steep, normal overprint that was generally removed after AF demagnetization at peak fields of 15-20 $\mathrm{mT}$, demonstrating that the $20 \mathrm{mT}$ magnetic cleaning level is, in general, sufficient to eliminate the overprint. The samples also appear to acquire a significant amount of anhysteretic remanent magnetization (ARM) at high peak field ( $>55 \mathrm{mT}$ ) AF demagnetization steps, possibly because of bias caused by ambient magnetic field during demagnetization. We calculated component NRM directions of the discrete samples from data from the 25-50 mT demagnetization steps using principal component analysis (Kirschvink, 1980) and the UPmag software (Xuan and Channell, 2009). Component inclinations of discrete samples with maximum angular deviation less than $\sim 15^{\circ}$ are shown as yellow circles in Figure F23 (first panel).

Magnetic susceptibility measurements were made on whole cores from all five holes as part of the WholeRound Multisensor Logger (WRMSL) analysis and on archive-half split-core sections using the Section Half Multisensor Logger (SHMSL) (see "Physical properties"). Magnetic susceptibility is consistent between the two instruments and is, in general, parallel to the intensity of magnetic remanence. WRMSL susceptibility was stored in the database in raw meter units. These were multiplied by a factor of $0.68 \times 10^{-5}$ to convert to the dimensionless volume SI unit (Blum, 1997). A factor of $(67 / 80) \times 10^{-5}$ was multiplied by the SHMSL acquired susceptibility stored in the database. Magnetic susceptibility varies between $5 \times 10^{-5}$ and $40 \times 10^{-5}$ SI (Fig. F23, fourth panel). Note that in Figure F23, a constant of $25 \times 10^{-5}$ SI was added to the SHMSL measurements (gray lines) to facilitate the comparison with the WRMSL measurements (black lines).

\section{Magnetostratigraphy}

The lack of core orientation and the significant coring disturbance and drill string overprint in the XCB and RCB cores limit our magnetostratigraphic interpretation to rely entirely on changes in magnetic inclination and occasionally on measurements of discrete samples taken from the relatively undisturbed drilling biscuits. The geomagnetic field at the latitude of Site U1389 $\left(36.43^{\circ} \mathrm{N}\right)$ has an expected inclination of $55.88^{\circ}$, assuming a geocentric axial dipole field model, which is sufficiently steep to determine magnetic polarity in cores that lack horizontal orientation.

The LO of nannofossil $R$. asanoi (0.905 Ma) in Hole U1389A at 327.6 mbsf (see "Biostratigraphy") sug- gests that the position of the Brunhes-Matuyama polarity transition is located at a slightly shallower depth. However, recovery in this part of the cored section is poor and the overprint appears to be relatively strong. Results from discrete samples from this interval intended to resolve the Brunhes-Matuyama transition are mostly inconclusive. Discrete sample from 335.12 mbsf in Hole U1389A (Sample 339U1389A-37X-3W, 71-73 cm), exhibits reversed polarity and is clearly located within the Matuyama Chron (C1r) (Figs. F23, F24). Results from Hole $\mathrm{U} 1389 \mathrm{C}$ are similar, with the LO of $R$. asanoi at $\sim 327.17$ mbsf, poor XCB recovery, and a significant coring-induced overprint. Core 339-U1389C-38X ( $345-350$ mbsf) contains reversed intervals and appears to be located in the Matuyama Chron.

The NRM inclination in the RCB section of Hole U1389E between $\sim 335$ and $~ 990$ mbsf defines several long normal and reversed polarity chrons (Fig. F23; Table T20). The dominantly reversed polarity interval between $\sim 335$ and $\sim 542$ mbsf contains the FO of $R$. asanoi (1.08 Ma) and the LO of C. macintyrei (1.66 Ma) (see "Biostratigraphy"), which constrains this interval to the Matuyama Chron (C1r). Evidence for the Jaramillo and Cobb Mountain Subchrons in this overprinted and poorly recovered part of the section could not be found. The long normal polarity interval between $\sim 542$ mbsf and $\sim 592$ mbsf correlates to the Olduvai Chron $(\mathrm{C} 2 \mathrm{n})$ and is well constrained by the LO of C. macintyrei (1.66 Ma) and the FO of G. inflata $(2.09 \mathrm{Ma})$. The reversed Subchrons C2r.1r and C2r.2r between $\sim 592$ and $\sim 696$ mbsf are well constrained by several nannofossil and planktonic foraminifer events, notably the LOs of G. punticulata (2.41 Ma) and D. surculus (2.53 Ma). A short normal polarity interval at $\sim 636 \mathrm{mbsf}$ is assigned to the Reunion Subchron (C2r.1n). The Matuyama/Gauss boundary appears well defined at 696 mbsf. The Gauss normal chron is constrained by several biostratigraphic datums: the LOs of $D$. tamalis $(2.9 \mathrm{Ma})$, D. altispira (3.17 Ma), and S. seminulina (3.19 Ma). The two reversed intervals within the Gauss normal chron are tentatively interpreted as the Kaena (C2An.1r) and Mammoth (C2An.2r) Subchrons. The temporal disappearance of the planktonic foraminifer G. punticulata (3.57 Ma) at $~ 939.96$ mbsf suggests that the polarity transition to the termination of Chron C2Ar should occur near the base of the cored section, probably in Core 339-U1389E-67R. However, poor core recovery in the heavily overprinted and disturbed cores and an inconclusive discrete sample makes a sound magnetostratigraphic interpretation difficult. In the $\sim 990 \mathrm{~m}$ composite Pliocene-Pleistocene record of Site U1389, 11 polarity re- 
versals of the geomagnetic polarity timescale are present. Polarity boundaries recognized at Site U1389 are summarized in Table T20.

\section{Physical properties}

Physical properties at Site U1389 were determined in Holes U1389A-U1389E. High-resolution scanning on whole-round segments was performed with the WRMSL at $2.5 \mathrm{~cm}$ intervals. Below Core 339U1389E-38X, the interval was set to $1 \mathrm{~cm}$. NGR was determined at $20 \mathrm{~cm}$ intervals above and $10 \mathrm{~cm}$ intervals below Section 339-U1389A-25X-6, $20 \mathrm{~cm}$ intervals in Hole U1389B, $20 \mathrm{~cm}$ intervals above and $10 \mathrm{~cm}$ intervals below Core 339-U1389C-34X, and $10 \mathrm{~cm}$ intervals in Holes U1389D and U1389E. The Special Task Multisensor Logger (STMSL) was only used for Holes U1389B, U1389C, and U1389D for stratigraphic correlation purposes at a scanning interval of $2.5 \mathrm{~cm}$. Thermal conductivity probes were applied on Section 339-U1389A-1H-3 to Core 339U1389A-23X. $P$-wave velocity was measured on splitcore segments (working half) from APC Cores 339U1389A-1H through $11 \mathrm{H}$ and on discrete samples of sufficiently indurated sediment pieces from Hole U1389E. Moisture and density (MAD) measurements were determined on discrete samples from every other section of Holes U1389A and U1389E. Color reflectance analysis and split-core point-magnetic measurements were collected at $5 \mathrm{~cm}$ intervals.

Based on the physical property data, two main intervals were identified at Site U1389 (Figs. F25, F26, F27). The upper interval (physical properties Unit I) is from 0 to 722.7 mbsf (base of Core 339-U1389E42R). Although distinct shifts, especially in magnetic susceptibility, are present throughout this interval, a consistent relation holds between lithology and physical properties. Beds of coarser grain size correspond to higher gamma ray attenuation (GRA) density, magnetic susceptibility, and $\mathrm{a}^{*}$ reflectance values (i.e., more reddish color, probably indicative of more Fe oxides in the sediment) than for the otherwise muddy sediment. Physical properties Unit I was divided into five subunits.

Physical properties Subunit IA covers the upper 0$178 \mathrm{mbsf}$ and is characterized by relatively high and variable magnetic susceptibilities and GRA densities as well as widely fluctuating $\mathrm{a}^{*}$ values. A distinct interval, physical properties Subunit IB, can be discerned from 178 to 217 mbsf (Cores 339-U1389A$21 \mathrm{X}$ through $25 \mathrm{X}$ ) and displays high NGR values and low $\mathrm{a}^{*}$ values (i.e., more greenish colors), as well as magnetic susceptibilities and GRA densities with fluctuations similar to the subunit above but with considerably reduced scatter of the data (Figs. F25,
F26). Lithologically, this interval is dominated by mud with only a few coarse-grained beds (see "Lithostratigraphy"). Physical properties Subunit IC ranges from 217 to $321 \mathrm{mbsf}$ and has more scatter in the GRA density and magnetic susceptibility data than the data from physical properties Subunit IB. Neither of the discussed physical property parameters shows distinct long-term fluctuations comparable to those in physical properties Subunit IA. Exceptions are $\mathrm{a}^{*}$, with a prominent minimum between 270 and $300 \mathrm{mbsf}$, and pronounced oscillations of $\mathrm{L}^{*}$ between 280 and 321 mbsf. The base of physical properties Subunit IC coincides with the base of lithologic Subunit IA (see "Lithostratigraphy").

Physical properties Subunit ID is identified from 321 to 406 mbsf, similar in depth to lithologic Subunit IB. This subunit's upper boundary coincides with a major unconformity in the seismic record and is generally marked by an increase in magnetic susceptibility, although poor core recovery makes detailed analyses problematic. A distinct characteristic of physical properties Subunit ID, in contrast to other subunits determined within physical properties Unit $\mathrm{I}$, is that some of its muddy intervals have high magnetic susceptibility values. Downhole logging shows a distinct increase in variability in the standard (total) gamma ray (HSGR) data (see "Downhole measurements") that is not apparent in the NGR data. This increased variability is interpreted to represent an increase in the abundance of sandy beds. Dominance of coarse-grained beds is not supported by the lithologic evidence; lithologic Subunit IB is characterized by the reduced presence of silty or sandy mud beds. The poor core recovery, however, suggests that sandy intervals were lost during core retrieval, biasing the record.

Physical properties Subunit IE, from 406 to 720 mbsf, encompasses lithologic Subunits IC and ID and represents a return to physical property characteristics similar to those of physical properties Subunit IC, particularly low magnetic susceptibility. Core recovery is slightly better than in physical properties Subunit ID, but gaps in the record and drilling disturbance result in considerable data scatter.

Below 720 mbsf to the base of Hole U1389E, physical properties Unit II is identified. The upper boundary of this interval is slightly deeper than the upper boundary of lithologic Subunit ID (see "Lithostratigraphy"). Although no particularly obvious change in the characteristics of individual physical property records is apparent, the relationship between the different parameters changes remarkably. The previously consistent positive correlation between GRA density, magnetic susceptibility, 
and $\mathrm{a}^{*}$ becomes more complex, in that GRA densities and magnetic susceptibility are partly positively but also negatively correlated. The very low magnetic susceptibility might obscure the signal here. The boundary at $\sim 720$ mbsf roughly coincides with inferred lithologic changes at $\sim 710$ mbsf as well as the defined Pliocene/Pleistocene boundary determined from biostratigraphy ( 700 mbsf) and paleomagnetic (696 mbsf) studies (see "Biostratigraphy" and "Paleomagnetism"), supporting the assumption that changes in the depositional environment occurred here. However, the offset between the discussed physical property changes and stratigraphic boundaries determined by other methods exists and needs further study. The downhole increase in the ratio of downslope-transported material to contourite deposits might serve as an explanation for the more complex relations between the physical properties as compared to the upper part of Site U1389 (especially within lithologic Subunit IA). Here, contourites are believed to be exclusively responsible for the formation of coarse-grained layers, explaining the more uniform relation between lithology and physical properties in physical properties Unit I.

\section{Whole-Round Multisensor Logger and Special Task Multisensor Logger measurements}

Analyzing cores on the STMSL was skipped for Holes U1389A and U1389E because no immediate acquisition of data for stratigraphic correlation was necessary but was resumed for Holes U1389B-U1389D. Temperature equilibration before measurements with the WRMSL was at least $3 \mathrm{~h}$.

\section{Gamma ray attenuation bulk density}

GRA density at Site U1389 is highly variable, between 1.6 and $2.4 \mathrm{~g} / \mathrm{cm}^{3}$ (Fig. F25). The considerable scatter, in particular in cores retrieved by rotary drilling, might be related to core disturbance and the presence of small cracks and voids, particularly in intervals with high sand content. Also, the natural variations in grain size and sediment texture are clearly reflected in the GRA density record; increases in grain size commonly correspond to increases in GRA density. This matches the observation that sandy beds are generally poorly sorted (see "Lithostratigraphy"), leaving less open pore space than well-sorted sand and therefore increasing bulk density. In terms of long-term variations in GRA density, physical properties Subunit IA is characterized by four major cycles of a sawtooth-like pattern (a rapid downhole increase followed by a slower decrease) with superimposed small-scale variability. Physical properties Subunit IB shows four distinct peaks in GRA density without following a major trend. Physical properties Subunits IC-IE and Unit II are affected by increasing scatter, especially below 750 mbsf in intervals of poor core recovery, masking any potential long-term variability.

\section{Magnetic susceptibility}

As observed at the previous Expedition 339 sites, magnetic susceptibility has the highest average values (as high as $40 \times 10^{-5} \mathrm{SI}$ ) in the upper part of Hole U1389A (Fig. F25), decreasing downhole to $12 \times 10^{-5}$ to $15 \times 10^{-5}$ SI in physical properties Subunit IC. A second maximum can be distinguished in the lower part of physical properties Subunit ID between $~ 321$ and 406 mbsf, with peaks reaching again as high as $40 \times 10^{-5} \mathrm{SI}$. In this part of the record, relatively high magnetic susceptibility is also found in the more muddy parts of the sediment. Magnetic susceptibility decreases to values commonly around $10 \times 10^{-5} \mathrm{SI}$ below 640 mbsf (Fig. F25). As discussed above, a remarkable coherence between susceptibility and GRA density is observed for the coarse-grained intervals in physical properties Unit I, suggesting a relatively high content of magnetite and other magnetic minerals in the fine fraction of the sand layers. In this sense, smear slide analyses indicate the presence of opaque minerals in these layers (see "Lithostratigraphy"). As discussed for the previous sites, diagenesis might have degraded the magnetic signal by reducing fine-grained Fe oxides to Fe sulfides.

\section{$P$-wave velocity}

The WRMSL was used to gather sonic velocities for all holes at Site U1389, and an attempt was made to determine $P$-wave velocities on split cores in each section of Holes U1389A and U1389E (Fig. F25). Because of poor sediment-to-liner coupling, reasonable results from the WRMSL could only be obtained for the upper $\sim 22 \mathrm{~m}$ of cores retrieved with the APC. The $P$-wave velocity profile can be extended to $90 \mathrm{mbsf}$ by using the $P$-wave determinations on split cores in Hole U1389A. Although the sediment surface appeared to be smooth and should have provided an adequate coupling to the transducers, no clear acoustic signal could be attained at greater depth. The formation of small cracks in the relatively stiff and brittle sediment might have negatively affected signal propagation through the sediment. In Hole U1389E, measurements on adequately indurated pieces of sediment without core liner were carried out, which provided, in some cases, a signal sufficiently large for manual signal processing.

$P$-wave velocities follow GRA densities in the upper $22 \mathrm{mbsf}$, with values close to $1600 \mathrm{~m} / \mathrm{s}$ in the upper- 
most meter, a downhole decrease to $1500 \mathrm{~m} / \mathrm{s}$ to 4 mbsf, and a return to values close to $1600 \mathrm{~m} / \mathrm{s}$ at 13 mbsf. Below this depth, values scatter between 1450 and $1680 \mathrm{~m} / \mathrm{s}$ in accordance with the fluctuations in the GRA densities (Fig. F25). Because $1450 \mathrm{~m} / \mathrm{s}$ is lower than the sonic speed in water, such low values are most likely an underestimation of the true speed caused by cracks and voids in the sediment. Sonic velocities obtained for the same intervals by WRMSL and on split cores (either by manual or automatic processing) agree very well. $P$-wave velocities determined on discrete samples had maximum values of $1730 \mathrm{~m} / \mathrm{s}$ (Core 339-U1389E-38R) but were also as low as $1450 \mathrm{~m} / \mathrm{s}$ (Core 339-U1389A-11R). Here, the same problem occurs as for measuring split cores with liner: the pressure needed to provide good contact between the transducers and the sediment specimen creates small cracks that increase the traveltime of the acoustic signal through the sediment piece.

\section{Natural gamma radiation}

NGR scanning was performed on all cores from Site U1389. NGR counts fluctuate mostly between 20 and $45 \mathrm{cps}$ and exhibit cyclic patterns for the cores retrieved with the APC and XCB (Hole U1389A) (Fig. F26). These patterns are also consistent with the logging data (see "Downhole measurements"). In cores retrieved with the RCB (Hole U1389E), the signal is relatively noisy and large-scale cycles are hard to identify, which is also caused by gaps in core recovery. The relation of variations in the NGR record to other physical property data is not consistent. On a broad scale, it appears that $\mathrm{a}^{*}$ and NGR are anticorrelated. This is especially valid for the intervals of persistently low $\mathrm{a}^{*}$, such as 65-110, 180-205, and 265-295 mbsf, where somewhat elevated NGR values are apparent without matching $\mathrm{a}^{*}$ excursions in detail (Fig. F26). Low $\mathrm{a}^{*}$ is often, but not always, related to fine-grained sediment. It might be inferred that these intervals also contain more organic matter, usually associated with elevated uranium concentrations and/or higher amounts of potassiumbearing feldspars and mica, which would both enhance NGR counts. Because the sandy intervals are rather impure with a wide range of components, a more complex NGR signal could be expected.

\section{Moisture and density}

Determination of moisture content and density on discrete sediment samples was performed in every section of Hole U1389A (Fig. F27A) and downhole in Core 339-U1389E-2R (Fig. F27B). Generally, GRA and MAD densities are consistent (Fig. F25) when measured on APC and XCB cores. GRA densities measured on RCB cores are usually lower than the corresponding MAD values, resulting from the lower volume of the RCB cores that the GRA densiometer integrates over.

Moisture and porosity both decrease downhole, declining rapidly in the upper few meters from maximum values of $\sim 40 \%$ for moisture content and $70 \%$ for porosity to values of $17 \%-25 \%$ (moisture content) and $41 \%-56 \%$ (porosity) at $\sim 25$ mbsf (Fig. F27A). Downhole to $\sim 720 \mathrm{mbsf}$, a gradual decrease in moisture contents of $17 \%-22 \%$ and porosities of $35 \%-45 \%$ can be observed. Within this general decrease, a small shift to higher moisture contents and porosities is present at $295 \mathrm{mbsf}$, including increased scatter in the data until $\sim 700$ mbsf. The boundary between physical properties Subunit IE and Unit II at 720 mbsf apparently goes hand-inhand with a halt in sediment compaction because no further decreases in porosity and moisture content are observed below this depth. It is also notable that both parameters show minimums at this depth (705-745 mbsf) with little scatter in the records. Below 830 mbsf, the variability in moisture and porosity increases considerably (Fig. F27B). The reason for the low scatter close to the interval boundary is not obvious from the lithologic observations. Possibly, diagenetic overprint plays a role here.

Notable, with respect to the MAD calculations, is the distinct change in interstitial water chlorinity, with highest values of $800-850 \mathrm{mM}$ at depths between $\sim 350$ and 550 mbsf and a return to low chlorinities ( $<400 \mathrm{mM}$ ) below $~ 720$ mbsf (see "Geochemistry"). The anomalously high chlorinities, compared to seawater, occur in an interval with a relatively high scatter in grain density. Higher porosities (increased permeability) might explain advection of briny fluids, but no increase in porosity is observed in this interval. Porosities may have been underestimated because more salt precipitated during drying of the respective sediment samples, clogging pore space. However, a correction for the increased salt contents has not been performed, as they are assumed to be insignificant for the observed salinity variations (Blum, 1997). Additional uncertainties arise from calculations of the derived parameters that are done automatically by the software assuming a concentration of dissolved ions in pore water typical for seawater (Blum, 1997). Grain densities $<2.65 \mathrm{~g} / \mathrm{cm}^{3}$ (i.e., the grain density of quartz) in the interval where high chlorinities are observed might be due to the excess precipitation of halite (grain density $=\sim 2.20$ $\mathrm{g} / \mathrm{cm}^{3}$ ) and other salts from interstitial water during sample processing. Otherwise, grain densities vary between 2.65 and $2.85 \mathrm{~g} / \mathrm{cm}^{3}$. Lower variability is observed in physical properties Subunit IB and the upper part of Subunit IC (downhole to $250 \mathrm{mbsf}$ ). The 
relatively high grain densities are indicative of a significant amount of components other than quartz, such as carbonates and heavy minerals, in agreement with the lithologic description (see "Lithostratigraphy"). No obvious relation between grain densities in coarse- versus fine-grained sediments could be detected, pointing at a similar mineralogical composition independent of grain size.

\section{Thermal conductivity}

Thermal conductivity was measured once per core using the full-space probe, usually in Section 3 near the middle of sections of all cores at Site U1389A (see "Downhole measurements"). Because cores retrieved by XCB drilling are severely disturbed and affected by biscuiting, only thermal conductivity measurements taken from APC cores (339-U1389A-1H through $11 \mathrm{H})$ are considered here. Thermal conductivity varies between 1.0 and $2.1 \mathrm{~W} /(\mathrm{m} \cdot \mathrm{K})$, which is in the range of what was observed at the other sites. No clear trend is apparent in the data. A relationship between the thermal conductivity and the moisture content and porosity is also not evident, although pore water content should have an effect on thermal conductivity.

\section{Summary of main results}

The relation of physical property data allows the designation of two main intervals at Site U1389, divided by a boundary at $\sim 720$ mbsf. Above this depth, a coherent relation exists between high magnetic susceptibility and GRA densities, correlating with coarser intervals. This relationship becomes more complex below $\sim 720$ mbsf, where both parameters are occasionally inversely correlated. The interval boundary determined by means of physical properties is close to a major lithostratigraphic change at $\sim 710 \mathrm{mbsf}$ and the Pliocene/Pleistocene boundary at $\sim 700 \mathrm{mbsf}$. The reason for the offset between lithologic changes in relation of physical property parameters remains unclear and warrants further research. Color reflectance indicates that sand layers are mostly more reddish in color, whereas muddy intervals tend to be more greenish.

\section{Geochemistry \\ Volatile hydrocarbons}

Headspace gas analysis was performed as a part of the standard protocol required for shipboard safety and pollution prevention monitoring. In total, 39 headspace samples from Hole U1389A and 63 headspace samples from Hole U1389E (sampling resolution of one per core) were analyzed (Fig. F28; Table
T21), spanning the entire depth range of the site. In Holes U1389A and U1389E, we detected methane $\left(C_{1}\right)$, ethane $\left(C_{2}\right)$, ethene $\left(C_{2=}\right)$, propane $\left(C_{3}\right)$, and propene $\left(\mathrm{C}_{3=}\right)$. Methane ranges from $106.3 \mathrm{ppmv}$ near the seafloor to a maximum of $71,003 \mathrm{ppmv}$ at 100.21 mbsf (Section 339-U1389A-12X-3). Ethene does not exceed 2.9 ppmv in the samples in which it was detected, and ethane remains below $50 \mathrm{ppmv}$ in most samples, with a maximum of $244.4 \mathrm{ppmv}$ at 905.1 mbsf. Generally, both ethene and ethane show higher concentrations with depth, whereas methane concentrations decrease. Propane and propene remain low, with propene not exceeding 1.5 ppmv. Propane is at concentrations below $1 \mathrm{ppmv}$ above 750.72 mbsf. Below this depth, it displays an increasing trend, with a maximum of 92.0 ppmv at 905.1 mbsf.

As part of the safety protocol, we used ratios of hydrocarbon concentrations to determine their origin as biogenic versus thermogenic. Thermogenic gases can be identified by a $\mathrm{C}_{1} /\left(\mathrm{C}_{2}+\mathrm{C}_{3}\right)$ ratio of $<50$ (Claypool and Kvenvolden, 1983). A few samples at this site drop below this level; however, the absolute concentrations of heavier gases in those samples are too low to be a cause for concern.

\section{Sedimentary geochemistry}

Sediment samples were collected for analysis of solid-phase geochemistry (inorganic and organic carbon and nitrogen) at a resolution of approximately one sample per core in Holes U1389A and U1389E (Table T22), thereby spanning the full depth of the site. $\mathrm{CaCO}_{3}$ varies from 21 to $35 \mathrm{wt} \%$ (Fig. F29). At $\sim 360$ mbsf, $\mathrm{CaCO}_{3}$ concentrations display a sharp drop and slow rebound with depth to values characteristic of the top of the site. This sharp transition corresponds to samples barren in nannofossils (see "Biostratigraphy") and is close to but offset by $\sim 60$ $\mathrm{m}$ from the observed changes in interstitial water chemistry. Organic carbon varies between 0.4 and $1.2 \mathrm{wt} \%$ (Fig. F30A) from the seafloor to $355 \mathrm{mbsf}$ in Hole U1389A and 0.3 and $1.8 \mathrm{wt} \%$ in Hole U1389E between 341.4 and 986.1 mbsf.

Nitrogen (Fig. F30B) was measured downhole to 355 mbsf in Hole U1389A and between 341.4 and 986.1 mbsf in Hole U1389E. Measured nitrogen ranges from 0.008 to $0.24 \mathrm{wt} \%$, with Hole U1389E showing greater nitrogen concentrations than Hole U1389A, in particular an interval of much higher values between 400 and $600 \mathrm{mbsf}$. The $\mathrm{C} / \mathrm{N}$ ratio, used to distinguish the origin of organic matter (marine versus terrestrial) in the sediments (Emerson and Hedges, 1988; Meyers, 1997), indicates that the organic carbon is mainly a mix of marine and terrestrial inputs 
to a depth of 352 mbsf. Below this level, the ratios are distinctly marine, and the transition between the two regimes coincides with the observed transition in $\mathrm{CaCO}_{3}$ content (Figs. F29, F30C; Table T22). Unlike at Sites U1385-U1388, at Site U1389 an inverse relationship exists between total organic carbon (TOC) and $\mathrm{C} / \mathrm{N}$ ratios that is particularly evident in the uppermost 300 mbsf. The data suggest that at Site U1389, a greater input of organic matter was associated with greater marine productivity rather than a terrestrial source.

One hypothesis for the observed relationship between TOC and $\mathrm{C} / \mathrm{N}$ ratio is that it is due to riverine input of iron from the Iberian pyrite belt (Almodóvar et al., 1997). We theorize that changing sea level (Miller et al., 2005) has altered the spatial extent of river outflow as well as the magnitude of iron input to the surface waters of the Gulf of Cádiz, resulting in changes in marine productivity. The magnitude of sedimentation (see "Biostratigraphy") and iron-induced marine productivity at this site may have resulted in the marine values observed in the organic indexes measured at Site U1389 despite its proximity to land. We evoke this as a likely explanation for the differences between Sites U1389 and U1390. Further study at higher resolution, aided by carbon isotopic measurements, is needed to definitively determine the origin of the observed variability between sites.

\section{Interstitial water chemistry}

Sediment samples for postcruise high-resolution analysis were taken from the bottom of each section of the uppermost 200 mbsf in Hole U1389A using syringe plugs. Whole rounds for shipboard and shorebased interstitial water sampling were taken at a resolution of one per core in Hole U1389A and one every three cores in Hole U1389E. After encountering a sharp reversal in the downhole chlorinity trend in Hole U1389E around 565 mbsf, whole-round sampling resolution was temporarily increased to one per core until low recovery made this impractical.

\section{Major cations and anions}

Sulfate decreases sharply from $18.4 \mathrm{mM}$ at seafloor to $0 \mathrm{mM}$ at $13.3 \mathrm{mbsf}$ at Site U1389 (Fig. F31A; Table T23) and remains undetectable downhole until the base of the site except for two samples between 730 and 750 mbsf in which 3-4 mM of sulfate was measured. These samples were taken in cores recovered by RCB in which drill-fluid contamination of the interstitial water sample is more likely than in cores recovered with the APC. The samples were also well compacted and crumbled easily because of their low porosity, which made proper removal of the contaminated outer rind more difficult. Drill fluid is com- posed of surface seawater, which has high (typically $\sim 29 \mathrm{mM}$ ) concentrations of sulfate. Therefore, the sulfate signal is likely attributable to minor sample contamination.

Ammonium varies but generally increases from 1000 $\mu \mathrm{M}$ at the seafloor to a maximum of $6485 \mu \mathrm{M}$ at 533 mbsf (Fig. F31B). Large increases in ammonium take place in the sulfate reduction zone, from 1000 to $2751 \mu \mathrm{M}(\sim 132 \mu \mathrm{M} / \mathrm{m})$, and between 293 and 533 mbsf, where the concentration increases from 3864 to $6485 \mu \mathrm{M}(\sim 11 \mu \mathrm{M} / \mathrm{m})$. The location of the ammonium concentration maximum is the same as the location of the maximums of many other elements. Below 533 mbsf, ammonium generally decreases and is $4320 \mu \mathrm{M}$ at the base of the site.

Alkalinity is variable in the upper $292 \mathrm{~m}$ of the site, with a maximum in the uppermost $3 \mathrm{mbsf}$ of 10.3 $\mathrm{meq} / \mathrm{L}$ and a minimum of $5.01 \mathrm{meq} / \mathrm{L}$ at $60.6 \mathrm{mbsf}$ (Fig. F31C). At 318 mbsf, alkalinity drops sharply and remains between 1.8 and $3.1 \mathrm{meq} / \mathrm{L}$ downhole to $565.3 \mathrm{mbsf}$, where its value begins to increase again. From 677.5 mbsf to the base of the site, alkalinity values vary between 3.5 and $8.4 \mathrm{meq} / \mathrm{L}$.

Magnesium and calcium both decrease sharply, from 51 to $35 \mathrm{mM}$ and from 7.7 to $5 \mathrm{mM}$ respectively, in the sulfate reduction zone (Fig. F32A, F32B). The decrease in magnesium is approximately six times greater than that of calcium, which indicates that both in situ dolomitization of calcite and authigenic dolomite precipitation are occurring. The sharp decrease in alkalinity (Fig. F31C) and increase in ammonium (Fig. F31B) coincident with the sulfate decrease are also evidence that the sulfate reduction reaction is occurring:

$$
\begin{gathered}
53 \mathrm{SO}_{4}{ }^{2-}+\mathrm{C}_{106} \mathrm{H}_{263} \mathrm{O}_{110} \mathrm{~N}_{16} \mathrm{P} \rightarrow 39 \mathrm{CO}_{2}+67 \mathrm{HCO}_{3}{ }^{-}+ \\
16 \mathrm{NH}_{4}{ }^{+}+53 \mathrm{HS}^{-}+39 \mathrm{H}_{2} \mathrm{O}+\mathrm{HPO}_{4}{ }^{2-} .
\end{gathered}
$$

The sharp sulfate-methane transition that occurs at the base of the sulfate reduction zone is presumably because anaerobic methane oxidation in the presence of sulfate (i.e. $\mathrm{CH}_{4}+\mathrm{SO}_{4}{ }^{2-} \rightarrow \mathrm{HCO}_{3}{ }^{-}+\mathrm{HS}^{-}+$ $\mathrm{H}_{2} \mathrm{O}$ ) erases the signal of diffusive penetration of methane into the sulfate reduction zone above (Gieskes, 1983; Boetius et al., 2000).

From 13.3 to 263 mbsf, magnesium concentration varies around a constant value, but calcium concentration increases to $7.25 \mathrm{mM}$, indicating diagenetic dissolution of calcite (Fig. F32A, F32B). Between 263 and 533 mbsf, magnesium and calcium increase linearly in roughly a 5:2 ratio. Both have a maximum at 533 mbsf, magnesium at $63.6 \mathrm{mM}$ and calcium at $20.0 \mathrm{mM}$. Concentrations then decrease to 11.1 and $2.68 \mathrm{mM}$, respectively, at $677 \mathrm{mbsf}$, below which they vary only slightly to the base of the site. Magne- 
sium values at the base of the site are $\sim 20 \mathrm{mM}$ lower than those above the section in which concentration greatly increases, whereas calcium concentrations at the base of the site are similar to those in the top sections.

Potassium concentration in the interstitial water decreases sharply in the sulfate reduction zone, from 9.96 to $7.96 \mathrm{mM}$ (Fig. F32C). Potassium then continues to decrease slowly over the next $200 \mathrm{~m}$ by $2 \mathrm{mM}$. In the depth interval between 263 and 533 mbsf, where many other large property changes were observed, the potassium concentration remains roughly constant, oscillating between 5.8 and $7 \mathrm{mM}$. From 533 mbsf to the base of the site, potassium concentration decreases another $3.5 \mathrm{mM}$ to a minimum value of 2.63 .

Sodium and chloride do not show much variation from their respective bottom water values of 490.8 and $584.8 \mathrm{mM}$ in the uppermost $\sim 250 \mathrm{~m}$ of Site U1389 (Fig. F33A, F33B). Starting at $263.4 \mathrm{mbsf}$, sodium and chloride both begin to increase and reach maxima at 533 mbsf of 691.9 and $942.2 \mathrm{mM}$, respectively. Below this point, sodium and chloride decrease sharply to 323.8 and $356.5 \mathrm{mM}$ at $757.4 \mathrm{mbsf}$ and do not vary significantly to the base of the site.

The sodium/chloride ratio in seawater of 0.86 remains constant under the influence of evaporative processes. Deviations from this value in interstitial water sodium/chloride ratios can be caused by diagenetic mineral or evaporite dissolution, clay mineral transformations, or interactions with ocean crust through tectonic activity (Kastner et al., 1991). Between 41 and $185 \mathrm{mbsf}$, the sodium/chloride ratio is slightly greater than that of seawater (Fig. F33C), which suggests mild leaching of buried salt evaporite, perhaps halite $(\mathrm{NaCl})$. In the section of rapid change that precedes the maximum in many elements, an excursion in the sodium/chloride ratio to low values between 0.7 and 0.75 occurs. At the multi-elemental maximum at $533 \mathrm{mbsf}$, the sodium/ chloride ratio reaches its minimum value of 0.7 . Ratios of sodium/chloride below the seawater value with a simultaneous increase in both sodium and chloride concentrations suggest the waters are affected by hydrothermal reactions originating in the crust (Kelley et al. 2002).

\section{Minor elements}

Barium varies between 0 and $21.3 \mu \mathrm{M}$ in the uppermost 230.6 m of Site U1389 (Fig. F34A; Table T23). The concentration then increases rapidly to a maximum of $136.1 \mu \mathrm{M}$ at 533 mbsf that coincides with the maxima in strontium, chloride, sodium, magnesium, calcium, and ammonium. Barium then decreases rapidly to $7.1 \mu \mathrm{M}$ at $706.5 \mathrm{mbsf}$, below which it varies between 0 and $12.4 \mu \mathrm{M}$ to the base of the site.

Boron increases slightly in the uppermost $13 \mathrm{mbsf}$ from 479.7 to $510.7 \mu \mathrm{M}$ (Fig. F34B). The concentration then decreases to $\sim 220 \mu \mathrm{M}$ at $318.1 \mathrm{mbsf}$. A slight increase from $\sim 220$ to $264 \mu \mathrm{M}$ in the next $100 \mathrm{~m}$ occurs, after which boron decreases slowly to $\sim 216 \mu \mathrm{M}$ at $621.4 \mathrm{mbsf}$. From $621.4 \mathrm{mbsf}$ to the base of the site, boron concentrations fluctuate between 164.3 and $267.5 \mu \mathrm{M}$.

Iron decreases from 77.5 to $5 \mu \mathrm{M}$ in the uppermost $80 \mathrm{~m}$ of Site U1389 and then remains low to the base of the site (Fig. F34C). The majority of the decrease in iron, from 77.5 to $\sim 30 \mu \mathrm{M}$, occurs in the sulfate reduction zone. The formation of iron sulfide minerals (FeS and $\mathrm{FeS}_{2}$ ) is favored in sulfate reduction zones because it requires the presence of hydrogen sulfide, one of the products of the sulfate reduction reaction. The continuing decrease of iron concentration below the base of the sulfate reduction zone may indicate another source of hydrogen sulfide in the sediments.

Lithium concentration decreases from 43.4 to 24.8 $\mu \mathrm{M}$ in the uppermost 13.3 mbsf (Fig. F35A) but then increases to a maximum of $89.9 \mu \mathrm{M}$ at $533 \mathrm{mbsf}$, where sodium, magnesium, chloride, calcium, ammonium, barium, and strontium also have concentration maxima. From 533 to $650.4 \mathrm{mbsf}$, lithium concentration decreases to $58.3 \mu \mathrm{M}$. Lithium then increases to $84.9 \mu \mathrm{M}$ at $757.4 \mathrm{mbsf}$ and proceeds to decrease yet again to $\sim 65 \mu \mathrm{M}$ near the base of the site.

Silicon varies between 110 and $397 \mu \mathrm{M}$ between the seafloor and 420 mbsf but does not show a coherent trend with depth (Fig. F35B). Two high values of 394 and $397 \mu \mathrm{M}$ occur at 193 and $231 \mathrm{mbsf}$, respectively. Below 420 mbsf, the range of silicon values decreases to a third of the upper site variability, and values vary between 90.7 and $179 \mu \mathrm{M}$.

Strontium increases gradually from 72 to $120 \mu \mathrm{M}$ in the upper $292 \mathrm{~m}$ of Site U1389 (Fig. F35C). Around 292 mbsf, the rate of strontium change increases. Strontium concentration reaches a maximum of 539 $\mu \mathrm{M}$ at 533 mbsf. The concentration then decreases sharply to $134 \mu \mathrm{M}$ at $\sim 621$ mbsf and continues dropping slowly to $84 \mu \mathrm{M}$ at 707 mbsf. Strontium then varies slightly downhole to the base of the site.

\section{Stable isotopes}

Oxygen and hydrogen isotopes are $\sim 0.8 \%$ and $6 \%$, respectively, at the top of the core, reflecting Mediterranean Overflow Water (Fig. F36A, F36B; Table T24). Oxygen isotope values generally increase downhole, whereas hydrogen isotopes decrease below 200 mbsf. $\delta^{18} \mathrm{O}$ increases by $0.8 \%$ between 320 
and 400 mbsf, below which values average $~ 1.9 \%$ to the base of the hole except for two samples at 564 and $651 \mathrm{mbsf}$ that gave low, surfacelike $\delta^{18} \mathrm{O}$ values. Below 200 mbsf, $\delta \mathrm{D}$ values steadily increase, reaching a minimum of $-10.8 \%$ at 530 mbsf. Below 530 mbsf, $\delta \mathrm{D}$ increases to $-3 \%$ at $565 \mathrm{mbsf}$ and thereafter averages from $-7 \%$ o to $-9 \%$ to the base of the hole. There is a strong negative correlation between $\delta^{18} \mathrm{O}$ and $\delta \mathrm{D}$ (Fig. F37), which indicates that their values are influenced by a diagenetic reaction.

\section{Summary}

Routine headspace analysis detected only methane, ethane, ethane, propane, and propene at this site. We determined the source of the hydrocarbons to be predominantly biogenic with some thermogenic input downhole, but absolute concentrations of thermogenically sourced gases remained low.

Sediment analysis shows total organic carbon content to be low, close to $\sim 1 \mathrm{wt} \%$. $\mathrm{CaCO}_{3}$ content exhibits a sharp transition at $\sim 360$ mbsf, which is also observed in the nannofossil abundance and corresponds to a change in nitrogen content as well as a decreasing shift in the $\mathrm{C} / \mathrm{N}$ ratios. Based on our data we ascertain that below 360 mbsf, organic matter is of marine origin, whereas above $360 \mathrm{mbsf}$ it carries the signature of both marine and terrestrial endmembers. Unlike Sites U1385-U1388, total organic carbon and $\mathrm{C} / \mathrm{N}$ ratios at Site U1389 show a negative relationship that is stronger in the upper $300 \mathrm{~m}$ of the site but below statistical significance for the site as a whole.

The maxima observed in many of the interstitial water element concentration profiles around $533 \mathrm{mbsf}$ suggest that the same process controls their concentrations. The sharp transition in concentrations both above and below this maximum is indicative of either a physical barrier to vertical diffusion in the sediment or the lateral intrusion of fluid across this depth interval. The increase in concentrations is likely due to dissolution of minerals, which may have occurred locally or at a remote source. Dissolution of carbonate minerals and/or shells would increase the alkalinity of the interstitial water because of an increase in dissolved $\mathrm{CO}_{3}{ }^{2-}$ concentration. The observed drop in alkalinity at this depth interval thus requires that a lower alkalinity (higher acidity) and probably $\mathrm{CO}_{2}$-rich fluid was the cause of the carbonate dissolution.

The strong negative correlation between $\delta^{18} \mathrm{O}$ and $\delta \mathrm{D}$ (Fig. F37) is characteristic of clay mineral dehydration reactions (Kastner et al., 1991; Dählmann and de Lange, 2003). The silicate framework of many clay minerals is light in $\delta \mathrm{D}$ and heavy in $\delta^{18} \mathrm{O}$ (Savin and
Epstein, 1970). The breakdown of clays transmits this isotopic signature to the interstitial water. Furthermore, the release of sodium, which is found in the framework of many silicate clays, would explain the increase in sodium/chloride ratio in the interstitial water. The transition of smectite to illite, in particular, has been identified as an important process for fluid formation in deeply buried sediment of the Gulf of Cadiz (Hensen et al., 2007). However, clay diagenesis typically occurs at great depth (several $\mathrm{km})$ and begins at temperatures exceeding $\sim 60^{\circ} \mathrm{C}$ (Kastner et al., 1991). Downhole temperature profiles (see "Downhole measurements") in the upper 100 $\mathrm{m}$ of the site fit a linear trend of $21^{\circ} \mathrm{C} / \mathrm{km}$. Extrapolation of this trend indicates that the temperature at the base of the hole is $\sim 34^{\circ} \mathrm{C}$. This supports the hypothesis that the low salinity signal is a result of fluid migration from a deeper, higher temperature source.

\section{Downhole measurements}

\section{Logging operations}

Two holes were logged at this site, Holes U1389A and U1389E. Hole U1389A was cored with the APC/ $\mathrm{XCB}$ and had good conditions for logging. Logging the first hole at the site also enabled prediction of lithology of the unrecovered intervals prior to coring Holes U1389B-U1389E. Hole U1389E was cored with the RCB, resulting in a wide borehole and poor conditions for logging at this site.

\section{Hole U1389A}

Downhole logging measurements in Hole U1389A were made after completion of XCB coring to a total depth of $354.9 \mathrm{~m}$ drilling depth below seafloor (DSF). In preparation for logging, the hole was flushed with a $30 \mathrm{bbl}$ sweep of high-viscosity mud. The hole was displaced with $112 \mathrm{bbl}$ of bariteweighted mud (10.5 ppg), and the pipe was pulled up to $85.7 \mathrm{~m}$ DSF. Three tool strings were deployed in Hole U1389A, the triple combo, FMS-sonic, and VSI tool strings (Fig. F38; see also "Downhole measurements" and Table T6 in the "Methods" chapter [Expedition 339 Scientists, 2013b] for definitions of tool acronyms). The Accelerator Porosity Sonde (APS) was left out of the triple combo tool string because the APS is not designed for high-porosity formations and it often overestimates porosity in wide and rugose boreholes, both of which were expected in Hole U1389A based on the previous two logged sites (see Fig. F42 in the "Site U1387" chapter [Expedition 339 Scientists, 2013d]). This also allowed the Hostile Environment Natural Gamma Ray Sonde to be placed at the bottom of the tool string to record 
intervals with low core recovery at the base of the hole (Fig. F39; see also "Lithostratigraphy").

At 2240 h on 23 December 2011, the triple combo tool string (resistivity, density, and NGR tools) descended from the rig floor into the pipe (Fig. F40). The downlog proceeded at $1000 \mathrm{~m} / \mathrm{h}$ and reached the base of the hole at 355 mbsf. A short uplog was run from 355 to 280 mbsf to provide data to crosscheck with the main pass, which was logged up from $355 \mathrm{mbsf}$ to seafloor at $275 \mathrm{~m} / \mathrm{h}$.

Rig up of the FMS-sonic tool string started at $0330 \mathrm{~h}$ on 24 December. A downlog was taken at $730 \mathrm{~m} / \mathrm{h}$ to the base of the hole. Standard (high)-frequency Dipole Sonic Imager transmitter settings were used, with $P$-wave window settings of $130-190 \mu \mathrm{s} / \mathrm{ft}$. Two uphole passes of the FMS-sonic were run, Pass 1 to the base of the pipe and Pass 2 to the seafloor, at 550 $\mathrm{m} / \mathrm{h}$. Rig down was completed at $1100 \mathrm{~h}$.

Marine mammal watch for the VSP started at $\sim 1100$ h. The Sercel G. GUN parallel cluster (two 250 in $^{3}$ air guns separated by $1 \mathrm{~m}$ ) was ramped up in a soft-start procedure. The air gun cluster was positioned on the port side of the JOIDES Resolution at a water depth of $\sim 7$ mbsl with a borehole offset of $\sim 45 \mathrm{~m}$. The VSI tool string started its descent down Hole U1389A at $1145 \mathrm{~h}$. Before reaching the bottom of the hole, a short uplog was taken from 269 to 219 mbsf to depth-match the VSI gamma curve to the other logging runs. The survey started at $1300 \mathrm{~h}$, and 10 out of 11 stations recorded good sonic waveforms. Stations were spaced at roughly $25 \mathrm{~m}$ intervals, where the borehole was not washed out (Fig. F38). The survey finished at $1500 \mathrm{~h}$, and the tool was brought uphole.

\section{Hole U1389E}

Downhole logging measurements in Hole U1389E were made after completion of XCB coring to a total depth of $989.9 \mathrm{~m}$ DSF. In preparation for logging, the hole was flushed with a $50 \mathrm{bbl}$ sweep of high-viscosity mud and the bit was released at the bottom of the hole. The hole was displaced with $375 \mathrm{bbl}$ of bariteweighted mud (10.5 ppg), and the pipe was pulled up to a logging depth of $102.2 \mathrm{mbsf}$. Two tool strings were deployed in Hole U1389E, the triple combo and the FMS-sonic tool strings (Fig. F38; see also "Downhole measurements" and Table T6 in the "Methods" chapter [Expedition 339 Scientists, 2013b] for definitions of tool acronyms). The triple combo tool string included the resistivity, density, porosity, and NGR tools. The High-Resolution Laterolog Array (HRLA) was placed at the top of the tool string in order to obtain density and NGR data closer to the bottom of the hole.
The triple combo tool string started downhole at 0150 h on 2 January 2012 (Fig. F40). A bridge at 525 mbsf was passed, but a second bridge at $567 \mathrm{mbsf}$ blocked further downhole progress; therefore, the bottom $423 \mathrm{~m}$ of Hole U1389E remained unlogged. Rig up of the FMS-sonic tool string started at $0730 \mathrm{~h}$, and the first pass reached the same bridge that the triple combo tool string encountered (567 mbsf). The second pass was blocked by a bridge at $525 \mathrm{mbsf}$. A VSP had been planned for this hole but could not be run because of concerns that air gun shots could weaken the structural integrity of the JOIDES Resolution's sea chest (salt-water intake) that had been thinned by corrosion.

Differences in the seafloor depth given by the step in the NGR logs are partly accounted for by changes in tide level (Fig. F40). The triple combo tool string downlog and main pass found seafloor at $656 \mathrm{mbrf}$, and FMS-sonic Passes 1 and 2 found it at $654 \mathrm{mbrf}$, whereas the driller's mudline was at 656.2 mbrf. Tide level was high for triple combo logging $(+0.5$ to +1.4 $\mathrm{m})$, low for FMS-sonic logging ( -1.4 to $-1.0 \mathrm{~m})$, and $+0.1 \mathrm{~m}$ for the driller's mudline. Seas were calm (maximum peak-to-peak heave $=0.7 \mathrm{~m}$ ), giving little contribution to the offset. The balance of the offset probably comes from the wireline heave compensator being centered slightly differently for each seafloor depth determination. However, a good depth match of the open-hole NGR logs between logging runs with the core data was achieved using a seafloor depth of 656 mbrf for the triple combo main pass (Fig. F41).

In Hole U1389E, the triple combo main pass found seafloor at 654 mbrf and FMS-sonic Pass 2 found it at 653 mbrf (no mudline was taken in this RCB hole). The tide was rising for the triple combo run $(-0.5$ to $+0.1 \mathrm{~m})$ and falling for the FMS-sonic run (+0.4 to $-0.4 \mathrm{~m})$.

\section{Log data quality}

In Hole U1389A, the quality of the log data is good because the borehole diameter (10-11 inches) was close to the bit size. Few washouts were observed and they generally did not exceed 14 inches (Fig. F39). The widest intervals, exceeding 16 inches, were observed at 106 and $\sim 190$ mbsf. No bridges were found in Hole U1389A. Resistivity, sonic velocity, and NGR logs are generally robust to the moderate changes in hole diameter. The density log correlates well with measurements on cores, although there is some reduction in values in the larger washouts. The photoelectric effect log gave anomalously high values, $>10 \mathrm{~b} / \mathrm{e}^{-}$, because of barium in the logging mud. The FMS resistivity images were of good quality be- 
cause of good contact with the borehole wall in most of the borehole.

In Hole U1389E, log data quality was affected by the large borehole diameter, exceeding 14 inches in $67 \%$ of the logged interval, and exceeding the 18 inch limit of the Hostile Environment Litho-Density Sonde (HLDS) caliper arm in $25 \%$ of the interval (Fig. F42). Some caves were found (e.g., 222-234, 264269, and 297-309 mbsf), with a large one from 511 to 517 mbsf associated with very low values in all the logs. The large number of washouts indicates that this RCB hole was in significantly worse condition than the same interval (102-355 mbsf) in XCB Hole U1389A. A large amount of seawater circulation was required to keep the RCB bit clear of clay build-up and to prevent sand from building up around the drill pipe, often resulting in washout of the sand-rich sediment. Resistivity, sonic velocity, and NGR logs were generally robust to changes in hole diameter, although some reduction in values is evident in the larger washouts. The photoelectric effect log gave reasonable values $\left(<5 \mathrm{~b} / \mathrm{e}^{-}\right)$where good contact was made with the borehole wall; the $375 \mathrm{bbl}$ of bariteweighted mud only filled the lowermost $300 \mathrm{~m}$ of the hole, assuming an in-gauge hole. The FMS resistivity images were poor because of bad contact with the borehole wall in most of the borehole.

\section{Comparison of log data quality in the contrasting borehole conditions of Holes U1389A and U1389E}

Log data in Holes U1389A and U1389E cover a common interval between 100 and 350 mbsf that permits an assessment of log data quality, particularly in wide boreholes (Fig. F45). Hole U1389A was cored by $\mathrm{APC} / \mathrm{XCB}$, and U1389E was cored by RCB. Both coring systems used 9.875 inch diameter bits, but the resulting hole diameter was much wider in Hole U1389E than in Hole U1389A. Differences between the two holes include the number of water jets on the bits, six for the XCB (a Russian polycrystalline diamond compact bit) and four for the RCB (CC-4 model); the absence of roller cones on the XCB bit; the age of the hole, less than 2 days for the XCB hole and more than 4 days for the RCB hole in the common interval; and water circulation, which had to be maintained more vigorously in the deeper RCB hole to prevent the pipe from getting stuck.

Caliper data from the HLDS show that most of Hole U1389A was between 10 and 11 inches in diameter, not much wider than bit size (Fig. F45). In contrast, Hole U1389E was almost always $>12$ inches wide and was often wider than the maximum extent of the caliper arm, 18 inches. An indication that the hole reaches $>25$ inches wide (at 305-310 mbsf) is given by the "diameter of invasion" log, which is based on the separation of the deep- and shallow-reading HRLA resistivity logs. Hole U1389E is also "rougher" (more variable in diameter over short scales) and has some bridges (hole narrower than bit size), for example at 319 mbsf. The effect of these contrasts in hole diameter on the other logs is discussed below.

The HSGR logs have lower values in the wider hole, but in general the same trends and patterns are seen in the HSGR logs from both holes. Correction for hole diameter is possible based on the caliper logs. However, in rough holes like Hole U1389E, any small depth discrepancy between the gamma and caliper logs would lead to further errors being introduced into the $\log$, and it is not possible to accurately correct for hole sizes greater than the 18 inch caliper limit.

The bulk density logs offer a stark contrast between the two holes. In the wider parts of Hole U1389E, the sensors were unable to make good contact with the borehole wall and consequently read values as low as $1.15 \mathrm{~g} / \mathrm{cm}^{3}$, close to borehole fluid. In Hole U1389A, bulk density values typically match the MAD bulk density values. Where the holes are relatively smooth and not too wide, the log bulk density values overlay very closely (e.g., 195-215 mbsf). Even in Hole U1389A, some of the departures to lower density values correspond to small washouts and may be suspect (e.g., $190 \mathrm{mbsf}$ ).

Electrical resistivity is measured by the HRLA at five different depths of investigation. The deepest measurement (RLA5) is least affected by variations in borehole diameter. In general, the RLA5 logs from both holes overlay each other reasonably well, but the Hole U1389E $\log$ is noisier and drops to lower values in thin, washed out zones, as well as peaking to higher values where the hole narrows. The HRLA curves also have additional noise close to the metal drill pipe (100-140 mbsf). An additional HRLA log, the "true resistivity" computed from the five deepto-shallow reading measurements (not shown in the figure), apparently overcorrects, providing resistivity values in Hole U1389E that are higher than in Hole U1389A.

The sonic velocity logs from the two holes give wellmatched patterns and values in the upper part of the common section (100-220 mbsf). In the washed-out zones below 220 mbsf in Hole U1389E, velocity is sometimes underestimated, perhaps caused by a longer path for the sonic wave to travel. In the rough and wide 220-320 mbsf section, Hole U1389E velocities are on average $3.2 \%$ slower than those in Hole U1389A. Even though the velocity data repeat very well between Passes 1 and 2 in Hole U1389E, this is not necessarily a good indication that they are re- 
cording the true formation velocity well, rather that the two passes respond similarly to the hole conditions. Another note of caution is that the washed out zones tend to be sand-rich layers; thus their velocities would be underestimated more than those of other lithologies.

\section{Logging units}

The logged intervals at Site U1389 were assigned to one logging unit because no major base-level changes in the log data were discerned (Figs. F39, F42). At the scale of this unit, the NGR signal typically ranges from 20 to 60 gAPI, with few peaks above 70 gAPI below 400 mbsf. The signal is dominated by the radioactivity of potassium and thorium, with uranium contributing a relatively minor component $(<2.5 \mathrm{ppm})$ (Figs. F43, F44). Similar to the previous sites, potassium and thorium curves are closely correlated. As both of these elements are found in clay minerals, which are abundant (see "Lithostratigraphy"), the NGR signal is primarily tracking clay. Minerals like K-feldspar and mica also contribute to the NGR signal. In Hole U1389A, the density and sonic velocity logs increase downhole (Fig. F39), reflecting sediment compaction with depth.

Logging Unit 1 was divided into two subunits, mainly on the basis of changes in mineralogy inferred from the NGR logs and a change in character of the resistivity logs.

\section{Logging Subunit 1A: base of drill pipe to 318 mbsf}

Logging Subunit $1 \mathrm{~A}$ is characterized by medium-amplitude cycles in bulk density, NGR (and its uranium, thorium, and potassium components), resistivity, density, and sonic velocity values. Several orders of cycles are observed, varying from one to several tens of meters in thickness (Fig. F43). The potassium and thorium concentrations co-vary closely, suggesting that clay content controls these elements. The uranium concentrations correlate with the potassium and thorium concentrations at some depths but vary independently at others. As expected from downhole compaction, the resistivity, density, and sonic velocity logs have an increasing downhole trend and are generally well correlated.

Logging Subunit 1A at Site U1389 strongly resembles logging Subunits 1A observed in Holes U1386C and U1387C (see "Downhole measurements" in the "Site U1387" chapter [Expedition 339 Scientists, 2013d]). All of them are Pleistocene in age, although their lower boundaries are diachronous (see "Bio- stratigraphy" and "Lithostratigraphy" in the "Site U1386" chapter [Expedition 339 Scientists, 2013c]).

\section{Logging Subunit 1B: $\mathbf{3 1 8 - 5 6 8 ~ m b s f ~}$}

Logging Subunit 1B is distinguished from the subunit above by higher amplitude variability in the NGR logs (Figs. F43, F44), which have a succession of sometimes thin peaks. The potassium baseline $(\sim 0.6 \%)$ is similar to that in Subunit 1A, whereas thorium levels decrease to $2 \mathrm{ppm}$. This suggests that for Subunit 1B, fewer thorium-bearing minerals are present, and there is perhaps a dominance of low-thorium clays such as illite, which has been used as an indicator of terrestrial rather than marine origin (Rider, 1996). Uranium appears to be closely correlated with the potassium and thorium curves.

Subunit $1 \mathrm{~B}$ is also characterized by a decrease in resistivity values and a disappearance of higher frequency variability compared to the subunit above (Fig. F42). This decrease is most likely caused by a major increase in interstitial water salinity: sodium and chloride concentrations start to increase downhole from $263.4 \mathrm{mbsf}$, and reach a brinelike concentration maxima at 533 mbsf (Fig. F33; see also "Geochemistry"). An increase in the amount of ions in the pore water solution lowers the apparent formation resistivity. The sharp decrease in sodium and chloride concentrations from 533 to 757.4 mbsf has not been clearly recorded in the resistivity logs because the deepest resistivity data are at 541 mbsf.

In Subunit 1B, the NGR logs are sometimes well correlated with the caliper log (e.g., 360, 390, and 485495 mbsf) (Fig. F44), in contrast to the more common anticorrelation between these logs observed for most of the logged intervals on this expedition.

The top of Subunit $1 \mathrm{~B}$ is equivalent to lithostratigraphic Subunit IB, recognized in cores from 320 to 385 mbsf as dominated by calcareous mud lithologies (see "Lithostratigraphy"). However, $<50 \%$ of this subunit was recovered in cores, and log data give information on the unrecovered material. In this interval, especially from 318 to 360 mbsf, the NGR logs suggest the presence of meter- to several meter-thick sandy intervals interbedded with clay-rich intervals. Hole U1389A is in-gauge (close to bit diameter) in this interval, so there is good confidence in the log data. Thus, the muddy intervals seem to have been preferentially recovered in cores.

\section{Formation MicroScanner images}

Because of the good borehole conditions in Hole U1389A, FMS resistivity images reveal numerous resistive and conductive intervals whose thicknesses 
range between several centimeters and a few meters. Gradual and sharp transitions between alternations are observed. In Hole U1389A, the image quality is generally poor because of poor contact between the sensors and the borehole wall, although some intervals still provide reasonably good images. In some places, most of these alternations correlate very well with the density, NGR, and sonic curves (Fig. F46). Conductive beds on the FMS images correlate with lower values in the NGR log, lower bulk densities, lower resistivities, lower $P$-wave velocities (e.g., two conductive intervals from 317 to 320 and 326 to 328.5 mbsf in Fig. F46) and correspond to coarsegrained intervals (sands and silts). These intervals contrast with muddy intervals appearing as less conductive on the FMS images and correlating with higher values in the NGR log, higher bulk densities, higher resistivities, and higher $P$-wave velocities (e.g., two conductive intervals from 320 to 323 and 325 to 326 mbsf in Fig. F46). The good contrast between sandy and muddy intervals on the FMS images is interpreted as resulting from the presence of brine in the pore spaces, which lead to high conductivity in the more permeable layers (sand). At the scale of the boreholes, the FMS images have a downhole trend of increasing conductivity, especially below 320 mbsf, that we relate to the progressive downhole increase in pore water salinity (see "Geochemistry").

\section{Vertical seismic profile and sonic velocity}

Data provided by VSP in Hole U1389A and sonic velocity logs in Holes U1389A and U1389E help establish conversions between depth and two-way traveltime (TWT) and link the borehole logs to the seismic section.

Good stacks of sonic waveforms were obtained during the VSP survey. It was easier to clamp the geophone to the borehole wall in Hole U1389A than in the much wider holes in the two previous VSP surveys. All 11 of the stations yielded good check shot traveltimes, ranging from $0.990 \mathrm{~s}$ TWT at $110.0 \mathrm{mbsf}$ to $1.254 \mathrm{~s}$ TWT at the deepest station at $355.3 \mathrm{mbsf}$ (Fig. F47; Table T25). The original traveltimes were corrected to the sea level datum and are based on the first break of the sonic waveform.

Sonic traveltimes were also calculated from sonic log velocities and give TWTs very close to those from the VSP, assuming a velocity of $1.62 \mathrm{~km} / \mathrm{s}$ just below the seafloor. Sonic velocity logs were taken in Holes U1389A (88-337 mbsf) and U1389E (102-550 mbsf), and velocities increase downhole because of compaction. The TWT at $550 \mathrm{mbsf}$ is $1.460 \mathrm{~s}$, based on the sonic data.

\section{Heat flow}

Nine APCT-3 downhole temperature measurements in Holes U1389A, U1389C, and U1389D, ranged from $13.7^{\circ} \mathrm{C}$ at $19.5 \mathrm{mbsf}$ to $15.29^{\circ} \mathrm{C}$ at $89.6 \mathrm{mbsf}$ (Table T26), giving a geothermal gradient of $20.9^{\circ} \mathrm{C} / \mathrm{km}$ (Fig. F48). The measurements increase linearly with depth, and the trend line intersects the seafloor at $13.36^{\circ} \mathrm{C}$. Some scatter is present, as well as minor differences between the three holes. These differences are probably caused by (1) nonunique fits to the APCT-3 temperature equilibration curves to obtain the formation temperature and (2) lateral heterogeneity in heat flow leading to small temperature differences between the holes. Similar to Site U1386, the bottom water temperature was difficult to determine accurately from the APCT-3 temperature profiles. The intersection of the linear temperature trend with the seafloor probably gives the best estimate here.

Thermal conductivity under in situ conditions was estimated from laboratory-determined thermal conductivity using the method of Hyndman et al. (1974) (see "Physical properties" in the "Methods" chapter [Expedition 339 Scientists, 2013b]). The calculated in situ values are within $0.1 \%$ of the measured laboratory values. Thermal resistance was then calculated by integrating the inverse of the in situ thermal conductivity over depth (Fig. F48). A heat flow of 26.6 $\mathrm{mW} / \mathrm{m}^{2}$ was obtained from the linear fit between temperature and thermal resistance (Pribnow et al., 2000). This value is quite low for the Gulf of Cádiz area (Grevemeyer et al., 2009).

\section{Stratigraphic correlation}

The meters composite depth (mcd) scale for Site U1389 was based primarily on correlation of magnetic susceptibility between holes in the upper 190 mcd and on a combination of NGR and susceptibility below this depth. Logging NGR data (referred to as HSGR) in Hole U1389A, lithostratigraphic logs, and correlative features in susceptibility and NGR data from Sites U1385-U1387 were used to help guide the correlation in more complex intervals.

The correlation between Holes U1389A-U1389D is relatively straightforward downhole to $240 \mathrm{mcd}$ (Figs. F49, F50). Correlative features are sparse from 240 to $320 \mathrm{mcd}$, and the resulting mcd scale is more uncertain in this interval. Distinct susceptibility and NGR anomalies can be confidently correlated between Holes U1389A and U1389C in the interval from 320 to $385 \mathrm{mcd}$. Correlation from $385 \mathrm{mcd}$ to the base of the multi-cored section at $404 \mathrm{mcd}$ is 
poor because of poor core recovery in this interval in Holes U1389A, U1389C, and U1389E.

Composite section completeness is largely a function of the coring system used and the number of times an interval was cored. The upper $10 \mathrm{~m}$ of the section was quadruple APC cored and is complete. The uppermost cores from Holes U1389A, U1389C, and U1389D recovered the mudline, although invariably a few centimeters of the uppermost and soupiest material may be missing or disturbed in any of these cores. We shift Cores 339-U1389A-1H and 339U1389D-1H downward 14 and $20 \mathrm{~cm}$, respectively, relative to Hole U1389C to align several prominent susceptibility anomalies below $2.5 \mathrm{mcd}$. This should not be used to infer that the upper portions of the cores are missing the mudline; rather it is more likely an indication of differential expansion.

Triple APC coring in Holes U1389A, U1389C, and U1389D extends downhole to APC refusal depth of $\sim 107$ mcd ( $\sim 97 \mathrm{mbsf})$. A virtually complete composite section was constructed in this APC-cored interval, with the exception of three possible small gaps at about 58, 68, and $78 \mathrm{mcd}$, where the base of Cores 339-U1389A-7H through 9H, 339-U1389C-7H through $9 \mathrm{H}$, and $339-\mathrm{U} 1389 \mathrm{D}-8 \mathrm{H}$ through $10 \mathrm{H}$ are roughly aligned.

Below $107 \mathrm{mcd}$, the stratigraphic section was doublecored with the XCB system downhole to $355 \mathrm{mbsf}$ ( $393 \mathrm{mcd})$ in Holes U1389A and U1389C, with RCB coring in Hole U1389E overlapping the XCB-cored interval from 335 to 355 mbsf. Several relatively short gaps ( $2 \mathrm{~m}$ to a few centimeters) exist in the composite section below the base of Cores 339U1389A-13X and 339-U1389C-12X ( 120 mcd) as a result of incomplete recovery in some cores, some unfortunate aligning of coring gaps between the holes, and relatively ubiquitous biscuit-type coring disturbance. The most notable of these short gaps are at about 122, 145, 164, 212, 225, 235, 243, 254, 335, 347 , and $357 \mathrm{mcd}$. A gap of several meters likely exists in the composite section at $\sim 372-380 \mathrm{mcd}$, which is the coring break between the base of Cores 339-U1389A-36X and 339-U1389C-36X and the tops of 339-U1389A-37X and 339-U1389C-37X. Part of gap may be filled by core from Hole U1389E, but no confident correlations can be established between any of the cores from Hole U1389E and those from Holes U1389A or U1389C. We therefore did not include data from Hole U1389E for stratigraphic correlation purposes (see "Lithostratigraphy"). The last, clearly correlative susceptibility and NGR anomalies occur in Cores 339-U1389A-37X and 339-U1389C$37 \mathrm{X}$. Thus, below the base of these cores ( $385 \mathrm{mcd})$, the sizes of the gaps that occur in the composite section are very uncertain. Below $404 \mathrm{mcd}$ ( $355 \mathrm{mbsf})$, the section is only single-cored, so some material is not recovered between each core.

Although the exact amount of material missing cannot be determined precisely for those cores where the gaps align between holes or for the gaps between cores in single-cored intervals, estimates can be made in two ways. First, prior construction of mcd scales has shown that expansion between mcd and mbsf scales is $\sim 7 \%-15 \%$. Hence, a similar expansion should be expected at Site U1389. In fact, we observed that a moderately accurate mcd scale could be constructed by merely expanding the mbsf depth scale by $\sim 10 \%$. Ultimately, detailed correlation is necessary, but, where correlative features do not exist, using a $\sim 10 \%$ expansion factor serves as a useful guide and provides rough estimates for the amount of material that might have been missed in the coring gaps. Second, susceptibility and NGR records from Site U1389 correlate with those records from Sites U1385-U1387. Furthermore, logging NGR data from Holes U1389A and U1389E correlate well with NGR data from Site U1389 cores (Fig. F41). Using these correlations, we can estimate the relative amount of material missing within the coring gaps and adjust the mcd scale by an appropriate amount.

The offsets and composite depths in Holes U1389AU1389D are listed in Table T27. A growth factor of $1.12-1.13$ is calculated by linear regression for the multicored interval at Site U1389, indicating a 12\%$13 \%$ increase in mcd values relative to mbsf values (Fig. F51). Because of the very linear nature of the expansion, the mcd scale can readily be compressed by a factor 0.887 to produce a modified mbsf $^{*}$ scale that corresponds more closely to true coring depths while retaining the between hole correlations.

The five holes cored at Site U1389 provide enough material to produce a splice that is virtually complete in the upper $120 \mathrm{mcd}$ of the section, contains only relatively short gaps from 120 to $372 \mathrm{mcd}$, has one large gap from 372 to $380 \mathrm{mcd}$, and is poorly constrained from 385 to 404 mcd (Figs. F49, F50). Below $404 \mathrm{mcd}$, the section is single-cored in Hole U1389E. The spliced record is provided for the susceptibility (Table T28), which was first cleaned by removing data affected by section- and core-edge artifacts or that occurred in disturbed intervals or gaps, as listed in Tables T14 and T29.

\section{References}

Almodóvar, G.R., Sáez, R., Pons, J.M., Maestre, A., Toscano, M., and Pascual, E., 1997. Geology and genesis of the Aznalcóllar massive sulphide deposits, Iberian pyrite belt, Spain. Miner. Deposita, 33(1-2):111-136.

doi:10.1007/s001260050136 
Alvarez-Zarikian, C.A., Soter, S., and Katsonopoulou, D., 2008. Recurrent submergence and uplift in the area of ancient Helike, Gulf of Corinth, Greece: microfaunal and archaeological evidence. J. Coastal Res., 24(1):110125. doi:10.2112/05-0454.1

Baraza, J., Ercilla, G., and Nelson, C.H., 1999. Potential geologic hazards on the eastern Gulf of Cádiz slope (SW Spain). Mar. Geol., 155(1-2):191-215. doi:10.1016/ S0025-3227(98)00147-9

Bayliss, D.D., 1969. The distribution of Hyalinea balthica and Globorotalia truncatulinoides in the type Calabrian. Lethaia, 2(2):133-143. doi:10.1111/j.15023931.1969.tb01632.x

Berggren, W.A, Hilgen, F.J., Langereis, C.G., Kent, D.V., Obradovich, J.D., Raffi, I., Raymo, M.E., and Shackelton, N.J., 1995. Late Neogene chronology: new perspectives in high-resolution stratigraphy. Geol. Soc. Am. Bull., 107(11):1272-1287. doi:10.1130/00167606(1995)107<1272:LNCNPI>2.3.CO;2

Blum, P., 1997. Physical properties handbook: a guide to the shipboard measurement of physical properties of deep-sea cores. ODP Tech. Note, 26. doi:10.2973/ odp.tn.26.1997

Boetius, A., Ravenschlag, K., Schubert, C.J., Rickert, D., Widdel, F., Gieseke, A., Amann, R., Jørgensen, B.B., Witte, U., and Pfannkuche, O., 2000. A marine microbial consortium apparently mediating anaerobic oxidation of methane. Nature (London, U. K.), 407(6804):623626. doi:10.1038/35036572

Bottema, S., 1990. Holocene environment of the southern Argolid: a pollen core from Kiladha Bay. In Wilkinson, T.J., and Duhon, S.T. (Eds.), Excavations at Franchthi Cave, Greece (Fascicle 6): Franchthi Paralia: The Sediments, Stratigraphy, and Offshore Investigations: Bloomington, IN (Indiana Univ. Press), 117-130.

Carbonel, P., 1985. Néogène. In Oertli, H.J. (Ed.), Atlas des Ostracodes de France. Bull. Cent. Rech. Explor.-Prod. Elf-Aquitaine, 9:313-345.

Claypool, G.E., and Kvenvolden, K.A., 1983. Methane and other hydrocarbon gases in marine sediment. Annu. Rev. Earth Planet. Sci., 11(1):299-327. doi:10.1146/ annurev.ea.11.050183.001503

Dählmann, A., and de Lange, G.J., 2003. Fluid-sediment interactions at eastern Mediterranean mud volcanoes: a stable isotope study from ODP Leg 160. Earth Planet. Sci. Lett., 212(3-4):377-391. doi:10.1016/S0012821X(03)00227-9

Egbert, G.D., and Erofeeva, S.Y., 2002. Efficient inverse modeling of barotropic ocean tides. J. Atmos. Oceanic Technol., 19(2):183-204. doi:10.1175/15200426(2002)019<0183:EIMOBO>2.0.CO;2

Emerson, S., and Hedges, J.I., 1988. Processes controlling the organic carbon content of open ocean sediments. Paleoceanography, 3(5):621-634. doi:10.1029/ PA003i005p00621

Expedition 339 Scientists, 2013a. Expedition 339 summary. In Stow, D.A.V., Hernández-Molina, F.J., Alvarez Zarikian, C.A., and the Expedition 339 Scientists, Proc. IODP, 339: Tokyo (Integrated Ocean Drilling Program
Management International, Inc.). doi:10.2204/

iodp.proc.339.101.2013

Expedition 339 Scientists, 2013b. Methods. In Stow, D.A.V., Hernández-Molina, F.J., Alvarez Zarikian, C.A., and the Expedition 339 Scientists, Proc. IODP, 339: Tokyo (Integrated Ocean Drilling Program Management International, Inc.). doi:10.2204/iodp.proc.339.102.2013

Expedition 339 Scientists, 2013c. Site U1385. In Stow, D.A.V., Hernández-Molina, F.J., Alvarez Zarikian, C.A., and the Expedition 339 Scientists, Proc. IODP, 339: Tokyo (Integrated Ocean Drilling Program Management International, Inc.). doi:10.2204/ iodp.proc.339.103.2013

Expedition 339 Scientists, 2013d. Site U1386. In Stow, D.A.V., Hernández-Molina, F.J., Alvarez Zarikian, C.A., and the Expedition 339 Scientists, Proc. IODP, 339: Tokyo (Integrated Ocean Drilling Program Management International, Inc.). doi:10.2204/ iodp.proc.339.104.2013

Expedition 339 Scientists, 2013e. Site U1387. In Stow, D.A.V., Hernández-Molina, F.J., Alvarez Zarikian, C.A., and the Expedition 339 Scientists, Proc. IODP, 339: Tokyo (Integrated Ocean Drilling Program Management International, Inc.). doi:10.2204/ iodp.proc.339.105.2013

Faranda, C., and Gliozzi, E., 2008. The ostracod fauna of the Plio-Pleistocene Monte Mario succession (Roma, Italy). Boll. Soc. Paleontol. Ital., 47(3):215-267. http:// paleoitalia.org/media/u/archives/ 03_Faranda_Gliozzi_Parte1.pdf

Faugères, J.-C., and Mulder, T., 2011. Contour currents and contourite drifts. Dev. Sedimentol., 63:149-214. doi:10.1016/B978-0-444-53000-4.00003-2

Fernández-Puga, M.C., Vázquez, J.T., Somoza, L., Díaz del Rio, V., Medialdea, T., Mata, M.P., and León, R., 2007. Gas-related morphologies and diapirism in the Gulf of Cádiz. Geo-Mar. Lett., 27(2-4):213-221. doi:10.1007/ s00367-007-0076-0

Flores, J.-A., Colmenero-Hidalgo, E., Mejía-Molina, A.E., Baumann, K.-H., Hendericks, J., Larsson, K., Prabhu, C.N., Sierro, F.J., and Rodrigues, T., 2010. Distribution of large Emiliania huxleyi in the central and northeast Atlantic as a tracer of surface ocean dynamics during the last 25,000 years. Mar. Micropaleontol., 76(3-4):5366. doi:10.1016/j.marmicro.2010.05.001

García, M., Hernández-Molina, F.J., Llave, E., Stow, D.A.V., León, R., Fernández-Puga, M.C., Díaz del Río, V., and Somoza, L., 2009. Contourite erosive features caused by the Mediterranean Outflow Water in the Gulf of Cádiz: Quaternary tectonic and oceanographic implications. Mar. Geol., 257(1-4):24-40 doi:10.1016/j.margeo.2008.10.009

Gieskes, J.M., 1983. The chemistry of interstitial waters of deep sea sediments: interpretation of deep sea drilling data. In Riley, J.P., and Chester, R. (Eds.), Chemical Oceanography (Vol. 8): London (Academic), 221-269.

Grevemeyer, I., Kaul, N., and Kopf, A., 2009. Heat flow anomalies in the Gulf of Cadiz and off Cape San Vincente, Portugal. Mar. Pet. Geol., 26(6):795-804. doi:10.1016/j.marpetgeo.2008.08.006 
Habgood, E.L., Kenyon, N.H., Masson, D.G., Akhmetzhanov, A., Weaver, P.P.E., Gardner, J., and Mulder, T., 2003. Deep-water sediment wave fields, bottom current sand channels, and gravity flow channel-lobe systems: Gulf of Cádiz, NE Atlantic. Sedimentology, 50(3):483-510. doi:10.1046/j.1365-3091.2003.00561.x

Hanquiez, V., Mulder, T., Lecroart, P., Gonthier, E., Marchès, E., and Voisset, M., 2007. High-resolution seafloor images in the Gulf of Cádiz, Iberian margin. Mar. Geol., 246(1):42-59. doi:10.1016/j.margeo.2007.08.002

Hayward, B.W., 2002. Late Pliocene to middle Pleistocene extinctions of deep-sea benthic foraminifera ("Stilostomella extinction") in the southwest Pacific. J. Foraminiferal Res., 32(3):274-307. doi:10.2113/32.3.274

Hensen, C., Nuzzo, M., Hornibrook, E., Pinheiro, L.M., Bock, B., Magalhães, V.H., and Brückmann, W., 2007. Sources of mud volcano fluids in the Gulf of Cádizindications for hydrothermal imprint. Geochim. Cosmochim. Acta, 71(5):1232-1248. doi:10.1016/ j.gca.2006.11.022

Hernández-Molina, F.J., Llave, E., Somoza, L., FernándezPuga, M.C., Maestro, A., León, R., Medialdea, T., Barnolas, A., García, M., Díaz del Río, V., Fernández-Salas, L.M., Vázquez, J.T., Lobo, F., Alveirinho Dias, J.M., Rodero, J., and Gardner, J., 2003. Looking for clues to paleoceanographic imprints: a diagnosis of the Gulf of Cádiz contourite depositional systems. Geology, 31(1):19-22. doi:10.1130/00917613(2003)031<0019:LFCTPI>2.0.CO;2

Hernández-Molina, F.J., Llave, E., Stow, D.A.V., García, M., Somoza, L., Vázquez, J.T., Lobo, F.J., Maestro, A., Díaz del Río, V., León, R., Medialdea, T., and Gardner, J., 2006. The contourite depositional system of the Gulf of Cádiz: a sedimentary model related to the bottom current activity of the Mediterranean Outflow Water and its interaction with the continental margin. Deep-Sea Res., Part II, 53(11-13):1420-1463. doi:10.1016/ j.dsr2.2006.04.016

Hilgen, F.J., 1991. Extension of the astronomically calibrated (polarity) time scale to the Miocene/Pliocene boundary. Earth Planet. Sci. Lett., 107(2):349-368. doi:10.1016/0012-821X(91)90082-S

Hyndman, R.D., Erickson, A.J., and Von Herzen, R.P., 1974. Geothermal measurements on DSDP Leg 26. In Davies, T.A., Luyendyk, B.P., et al., Init. Repts. DSDP, 26: Washington, DC (U.S. Govt. Printing Office), 451-463. doi:10.2973/dsdp.proc.26.113.1974

Jiménez-Moreno, G., Fauquette, S., and Suc, J.-P., 2010. Miocene to Pliocene vegetation reconstruction and climate estimates in the Iberian Peninsula from pollen data. Rev. Palaeobot. Palynol., 162(3):403-415. doi:10.1016/j.revpalbo.2009.08.001

Kastner, M., Elderfield, H., and Martin, J.B., 1991. Fluids in convergent margins: what do we know about their composition, origin, role in diagenesis and importance for oceanic chemical fluxes? Philos. Trans. R. Soc. London, Ser. A, 335(1638):243-259. doi:10.1098/rsta.1991.0045

Kawagata, S., Hayward, B.W., Grenfell, H.R., and Sabaa, A., 2005. Mid-Pleistocene extinction of deep-sea foraminif- era in the North Atlantic Gateway (ODP Sites 980 and 982). Palaeogeogr., Palaeoclimatol., Palaeoecol., 221(34):267-291. doi:10.1016/j.palaeo.2005.03.001

Kelley, D.S., Baross, J.A., and Delaney, J.R., 2002. Volcanoes, fluids, and life at mid-ocean ridge spreading centers. Annu. Rev. Earth Planet. Sci., 30(1):385-491. doi:10.1146/annurev.earth.30.091201.141331

Kirschvink, J.L., 1980. The least-squares line and plane and the analysis of palaeomagnetic data. Geophys. J. R. Astron. Soc., 62(3):699-718. doi:10.1111/j.1365246X.1980.tb02601.x

Leckie, R.M., and Olson, H.C., 2003. Foraminifera as proxies of sea-level change on siliciclastic margins. In Olson, H.C., and Leckie, R.M. (Eds.), Micropaleontologic Proxies of Sea-Level Change and Stratigraphic Discontinuities. Spec. Publ.-SEPM (Soc. Sediment. Geol.), 75:5-19.

Llave, E., Hernández-Molina, F.J., Somoza, L., Stow, D.A.V., and Díaz Del Río, V., 2007a. Quaternary evolution of the contourite depositional system in the Gulf of Cádiz. Geol. Soc. Spec. Publ., 276:49-79. doi:10.1144/ GSL.SP.2007.276.01.03

Llave, E., Hernández-Molina, F.J., Stow, D.A.V., FernándezPuga, M.C., García, M., Vázquez, J.T., Maestro, A., Somoza, L., and Díaz del Río, V., 2007b. Reconstructions of the Mediterranean Outflow Water during the Quaternary based on the study of changes in buried mounded drift stacking pattern in the Gulf of Cádiz. Mar. Geophys. Res., 28(4):379-394. doi:10.1007/s11001-007-9040-7

Llave, E., Matias, H., Hernández-Molina, F.J., Ercilla, G., Stow, D.A.V., and Medialdea, T., 2011. Pliocene-Quaternary contourites along the northern Gulf of Cadiz margin: sedimentary stacking pattern and regional distribution. Geo-Mar. Lett., 31(5-6):377-390. doi:10.1007/s00367-011-0241-3

Lourens, L., Hilgen, F., Shackleton, N.J., Laskar, J., and Wilson, D., 2004. The Neogene period. In Gradstein, F.M., Ogg, J.G., and Smith, A. (Eds.), A Geologic Time Scale 2004: Cambridge (Cambridge Univ. Press), 409-440.

Maestro, A., Somoza, L., Medialdea, T., Talbot, C.J., Lowrie, A., Vázquez, J.T., and Díaz del Río, V., 2003. Large-scale slope failure involving Triassic and middle Miocene salt and shale in the Gulf of Cádiz (Atlantic Iberian margin). Terra Nova, 15(6):380-391. doi:10.1046/j.13653121.2003.00513.x

Maldonado, A., Somoza, L., and Pallarés, L., 1999. The Betic orogen and the Iberian-African boundary in the Gulf of Cádiz: geological evolution (central North Atlantic). Mar. Geol., 155(1-2):9-43. doi:10.1016/ S0025-3227(98)00139-X

Medialdea, T., Somoza, L., Pinheiro, L.M., Fernández-Puga, M.C., Vázquez, J.T., León, R., Ivanov, M.K., Magalhaes, V., Díaz del Río, V., and Vegas, R., 2009. Tectonics and mud volcano development in the Gulf of Cádiz. Mar. Geol., 261(1-4):48-63. doi:10.1016/j.margeo.2008.10.007

Medialdea, T., Vegas, R., Somoza, L., Vázquez, J.T., Maldonado, A., Díaz-del-Río, V., Maestro, A., Córdoba, D., and Fernández-Puga, M.C., 2004. Structure and evolution of the "Olistostrome" complex of the Gibraltar arc in the Gulf of Cádiz (eastern Central Atlantic): evidence from 
two long seismic cross-sections. Mar. Geol., 209(14):173-198. doi:10.1016/j.margeo.2004.05.029

Meyers, P.A., 1997. Organic geochemical proxies of paleoceanographic, paleolimnologic, and paleoclimatic processes. Org. Geochem., 27(5-6):213-250. doi:10.1016/ S0146-6380(97)00049-1

Miller, K.G., Kominz, M.A., Browning, J.V., Wright, J.D., Mountain, G.S., Katz, M.E., Sugarman, P.J., Cramer, B.S., Christie-Blick, N., and Pekar, S.F., 2005. The Phanerozoic record of global sea-level change. Science, 310(5752):1293-1298. doi:10.1126/science.1116412

Mulder, T., Lecroart, T.P., Voisset, M., Schönfeld, J., Le Drezen, E., Gonthier, E., Hanquiez, V., Zahn, R., Fauguères, J.-C., Hernandez-Molina, F.J., Llave-Barranco, E., Gervais, A., and the CADISAR and IMAGES V-GINNA Scientific Teams, 2002. Past deep-ocean circulation and the paleoclimate record-Gulf of Cádiz. Eos, Trans. Am. Geophys. Union, 83(43):481. doi:10.1029/ 2002EO000337

Mulder, T., Voisset, M., Lecroart, P., Le Drezen, E., Gonthier, E., Hanquiez, V., Faugères, J.-C., Habgood, E., Hernandez-Molina, F.J., Estrada, F., Llave-Barranco, E., Poirier, D., Gorini, C., Fuchey, Y., Volker, A., Freitas, P., Lobo Sanchez, F., Fernandez, L.M., and Morel, J., 2003. The Gulf of Cádiz: an unstable giant contouritic levee. Geo-Mar. Lett., 23(1):7-18. doi:10.1007/s00367-0030119-0

Murray, J.W., 2006. Ecology and Applications of Benthic Foraminifera: Cambridge (Cambridge Univ. Press).

Nelson, C.H., Baraza, J., and Maldonado, A., 1993. Mediterranean undercurrent sandy contourites, Gulf of Cádiz, Spain. Sediment. Geol., 82(1-4):103-131. doi:10.1016/0037-0738(93)90116-M

Nelson, C.H., Baraza, J., Maldonado, A., Rodero, J., Escutia, C., and Barber, J.H., Jr., 1999. Influence of the Atlantic inflow and Mediterranean outflow currents on late Quaternary sedimentary facies of Gulf of Cádiz continental margin. Mar. Geol., 155(1-2):99-129. doi:10.1016/S0025-3227(98)00143-1

Pribnow, D., Kinoshita, M., and Stein, C., 2000. Thermal Data Collection and Heat Flow Recalculations for Ocean Drilling Program Legs 101-180: Hanover, Germany (Inst. Joint Geosci. Res., Inst. Geowiss. Gemeinschaftsauf. [GGA]). http://www-odp.tamu.edu/publications/ heatflow/ODPReprt.pdf

Raffi, I., Backman, J., Fornaciari, E., Pälike, H., Rio, D., Lourens, L., and Hilgen, F., 2006. A review of calcareous nannofossil astrobiochronology encompassing the past 25 million years. Quat. Sci. Rev., 25(23-24):3113-3137. doi:10.1016/j.quascirev.2006.07.007

Raymo, M.E., Ruddiman, W.F., Backman, J., Clement, B.M., and Martinson, D.G., 1989. Late Pliocene variation in Northern Hemisphere ice sheets and North Atlantic deep water circulation. Paleoceanography, 4(4):413-446. doi:10.1029/PA004i004p00413

Rider, M.H., 1996. The Geological Interpretation of Well Logs (2nd ed.): Caithness (Whittles Publ.).

Ruiz, F., González-Regalado, M.L., Abad, M., Civis, J., González Delgado, J.A., Mara García, E.X., Prudêncio, M.I., and Dias, M.I., 2008. Pliocene ostracods of southwest- ern Europe. Geobios, 41(6):845-859. doi:10.1016/j.geobios.2007.07.004

Ruiz, F., Gonzalez-Regalado, M.L., Baceta, J.I., and Muñoz, J.M., 2000. Comparative ecological analysis of the ostracod faunas from low- and high-polluted southwestern Spanish estuaries: a multivariate approach. Mar. Micropaleontol., 40(4):345-376. doi:10.1016/S03778398(00)00048-7

Ruiz, F., González-Regalado, M.L., and Muñoz, J.M., 1997. Multivariate analysis applied to total and living fauna: seasonal ecology of recent benthic Ostracoda off the north Cádiz Gulf coast (southwestern Spain). Mar. Micropaleontol., 31(3-4):183-203. doi:10.1016/S03778398(96)00060-6

Savin, S.M., and Epstein, S., 1970. The oxygen and hydrogen isotope geochemistry of clay minerals. Geochim. Cosmochim. Acta, 34(1):25-42. doi:10.1016/00167037(70)90149-3

Schönfeld, J., 1997. The impact of the Mediterranean Outflow Water (MOW) on benthic foraminiferal assemblages and surface sediments at the southern Portuguese continental margin. Mar. Micropaleontol., 29(3-4):211236. doi:10.1016/S0377-8398(96)00050-3

Schönfeld, J., 2002. Recent benthic foraminiferal assemblages in deep high-energy environments from the Gulf of Cádiz (Spain). Mar. Micropaleontol., 44(3-4):141-162. doi:10.1016/S0377-8398(01)00039-1

Schönfeld, J., and Zahn, R., 2000. Late glacial to Holocene history of the Mediterranean Outflow. Evidence from benthic foraminiferal assemblages and stable isotopes at the Portuguese margin. Palaeogeogr., Palaeoclimatol., Palaeoecol., 159(1-2):85-111. doi:10.1016/S00310182(00)00035-3

Sierro, F.J., Hernandez-Almeida, I., Alonso-Garcia, M., and Flores, J.A., 2009. Data report: Pliocene-Pleistocene planktonic foraminifer bioevents at IODP Site U1313. In Channell, J.E.T., Kanamatsu, T., Sato, T., Stein, R., Alvarez Zarikian, C.A., Malone, M.J., and the Expedition 303/306 Scientists, Proc. IODP, 303/306: College Station, TX (Integrated Ocean Drilling Program Management International, Inc.). doi:10.2204/ iodp.proc.303306.205.2009

Somoza, L., Díaz-del-Rio, V., León, R., Ivanov, M., Fernández-Puga, M.C., Gardner, J.M., Hernández-Molina, F.J., Pinheiro, L.M., Rodero, J., Lobato, A., Maestro, A., Vázquez, J.T., Medialdea, T., and Fernández-Salas, L.M., 2003. Seabed morphology and hydrocarbon seepage in the Gulf of Cádiz mud volcano area: acoustic imagery, multibeam and ultra-high resolution seismic data. Mar. Geol., 195(1-4):153-176. doi:10.1016/S00253227(02)00686-2

Stow, D., Hernández-Molina, F.J., Hodell, D., and Alvarez Zarikian, C.A., 2011. Mediterranean outflow: environmental significance of the Mediterranean Outflow Water and its global implications. IODP Sci. Prosp., 339. doi:10.2204/iodp.sp.339.2011

Stow, D.A.V., and Faugères, J.-C., 2008. Contourite facies and the facies model. Dev. Sedimentol., 60:223-256. doi:10.1016/S0070-4571(08)10013-9 
Stow, D.A.V., Hernández-Molina, F.J., Llave, E., García, M., Díaz del Río, V., Somoza, L., and Bruno, M., in press. The Cádiz contourite channel: sandy contourites, bedforms and dynamic current interaction. Mar. Geol.

Stow, D.A.V., Hernández-Molina, F.J., Llave, E., Sayago-Gil, M., Díaz del Río, V., and Branson, A., 2009. Bedformvelocity matrix: the estimation of bottom current velocity from bedform observations. Geology, 37(4):327-330. doi:10.1130/G25259A.1

Szarek, R., Nomaki, H., and Kitazato, H., 2007. Living deep-sea benthic foraminifera from the warm and oxygen-depleted environment of the Sulu Sea. Deep-Sea Res., Part II, 54(1-2):145-176. doi:10.1016/ j.dsr2.2006.02.017

van Morkhoven, F.P.C.M., Berggren, W.A., and Edwards, A.S., 1986. Cenozoic Cosmopolitan Deep-Water Benthic Foraminifera. Bull. Cent. Rech. Explor.-Prod. Elf-Aquitaine, 11.
Xuan, C., and Channell, J.E.T., 2009. UPmag: MATLAB software for viewing and processing $U$ channel or other pass-through paleomagnetic data. Geochem., Geophys., Geosyst., 10(10):Q10Y07. doi:10.1029/2009GC002584

Zachariasse, W.J., Zijderveld, J.D.A., Langereis, C.G., Hilgen, F.J., and Verhallen, P.J.J.M., 1989. Early late Pliocene biochronology and surface water temperature variations in the Mediterranean. Mar. Micropaleontol., 14(4):339-355. doi:10.1016/0377-8398(89)90018-2

Zitellini, N., Gràcia, E., Matias, L., Terrinha, P., Abreu, M.A., DeAlteriis, G., Henriet, J.P., Dañobeitia, J.J., Masson, D.G., Mulder, T., Ramella, R., Somoza, L., and Diez, S., 2009. The quest for the Africa-Eurasia plate boundary west of the Strait of Gibraltar. Earth Planet. Sci. Lett., 280(1-4):13-50. doi:10.1016/j.epsl.2008.12.005

Publication: 17 June 2013

MS 339-107 
Figure F1. 3-D sketch showing the location of Site U1389 on a patch/sheeted drift north of the Guadalquivir diapiric ridge in the central sector of the contourite depositional system (made by H. Pereira, Escola Secundária de Loulé, using Mirone and iView4D software).

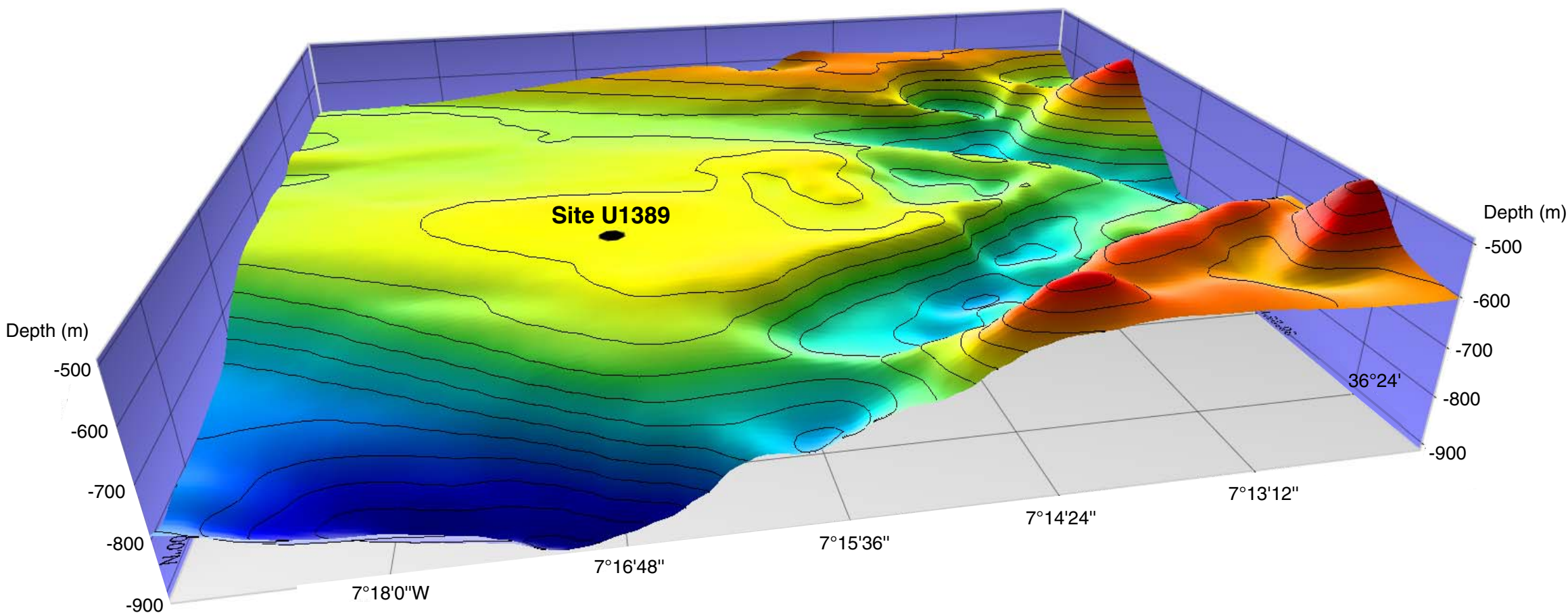
$-900$ 
Figure F2. Bathymetric sketch showing the location of Site U1389 in the central sector of the contourite depositional system (base map made by Dr. R. León, Geological Survey, IGME, Spain).

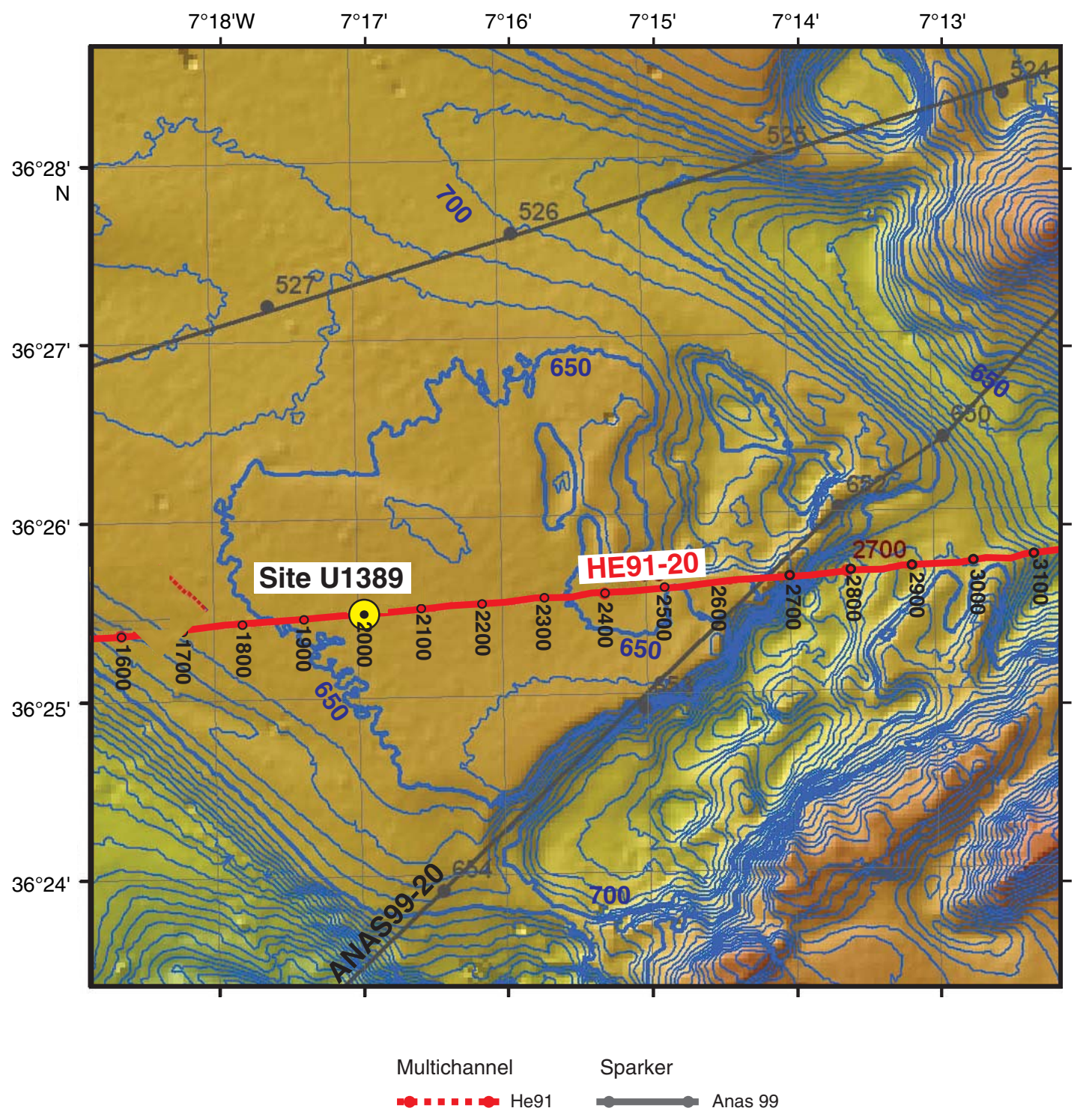


Figure F3. Swath bathymetry of the central sector of the middle slope of the Gulf of Cádiz contourite depositional system showing the main contourite channels and furrows and the main diapiric ridges, with a northnortheast trend (from Hernández-Molina et al., 2006).

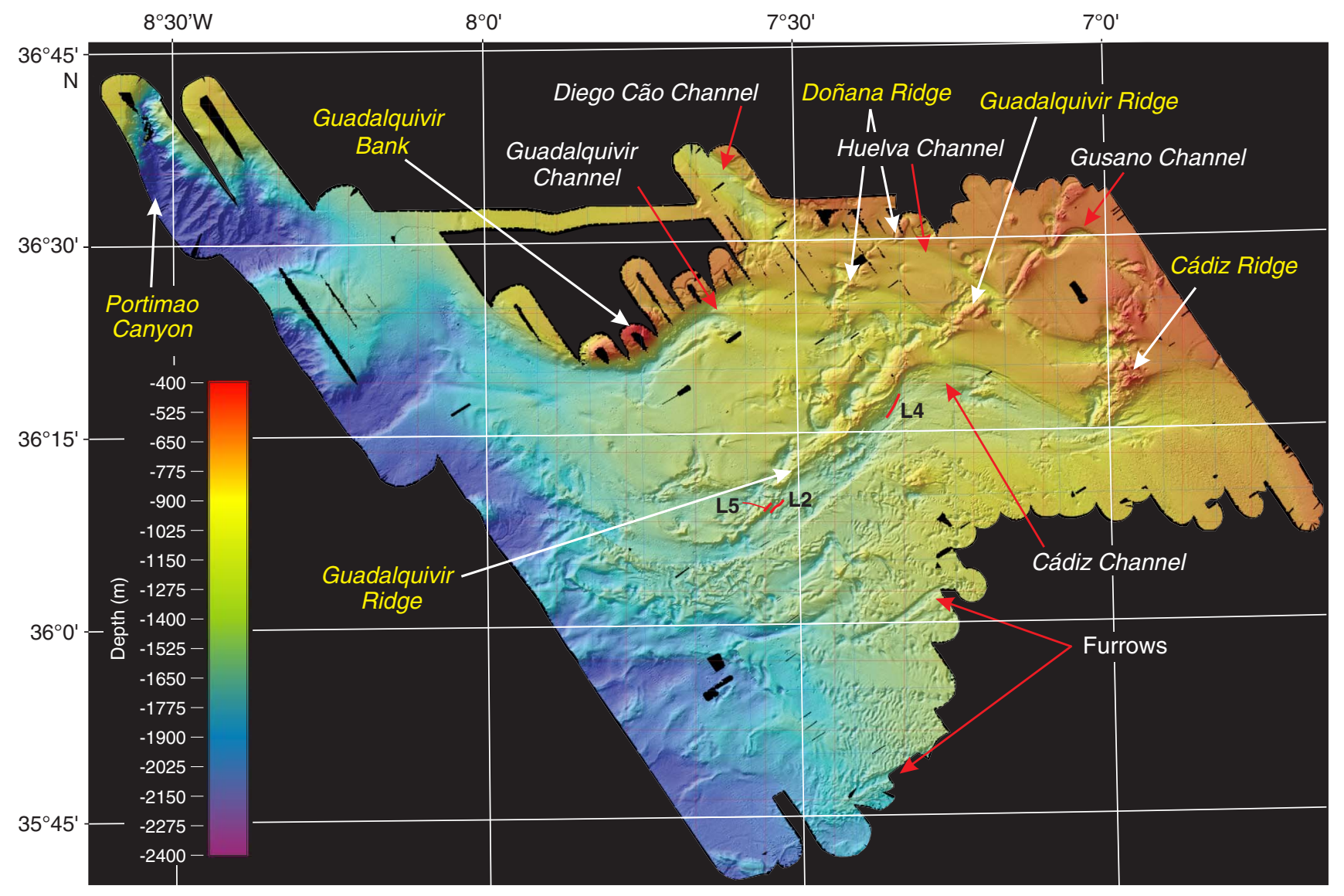


Figure F4. Characterization of the contourite channels (García et al., 2009). CC = contourite channel, GB = Guadalquivir Bank, CDR = Cádiz diapiric ridge, GDR = Guadalquivir diapiric ridge, DDR = Doñana diapiric ridge, SD = sheeted drift. A. Shaded relief image showing the Gulf of Cádiz middle slope bathymetry and location of the main contourite channels. B-H. Transversal seismic profiles showing the U- and V-shaped, symmetric or asymmetric profiles of the Diego Cão, Gusano, Huelva, Guadalquivir, and Cádiz contourite channels. In H, the Cádiz Channel shows a marked overexcavation in its axis.

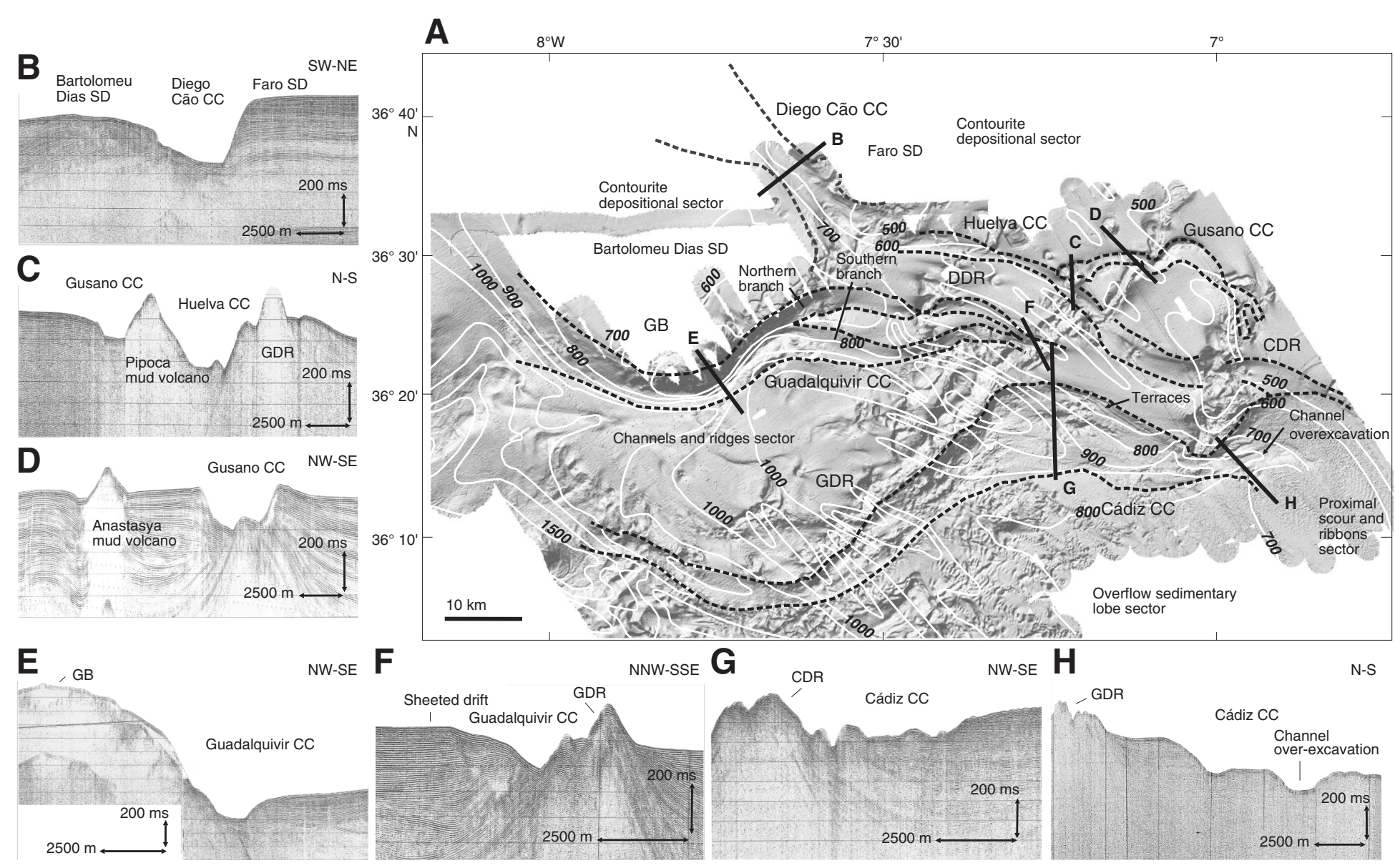


Figure F5. Seismic profile examples from the channels and ridges Sector 3 (from Hernández-Molina et al., 2006). A. Sketch of sector and seismic lines. B. Cádiz and Guadalquivir contourite channels bounded by the Guadalquivir diapiric ridge. C. Huelva contourite channel, Cádiz diapiric ridge, and a marginal valley. D. Gusano contourite channel. E. Diego Cão Channel. F. Large deformed sheeted drift caused by recent tectonic events in this sector. G. Deformed sheeted drift.

B

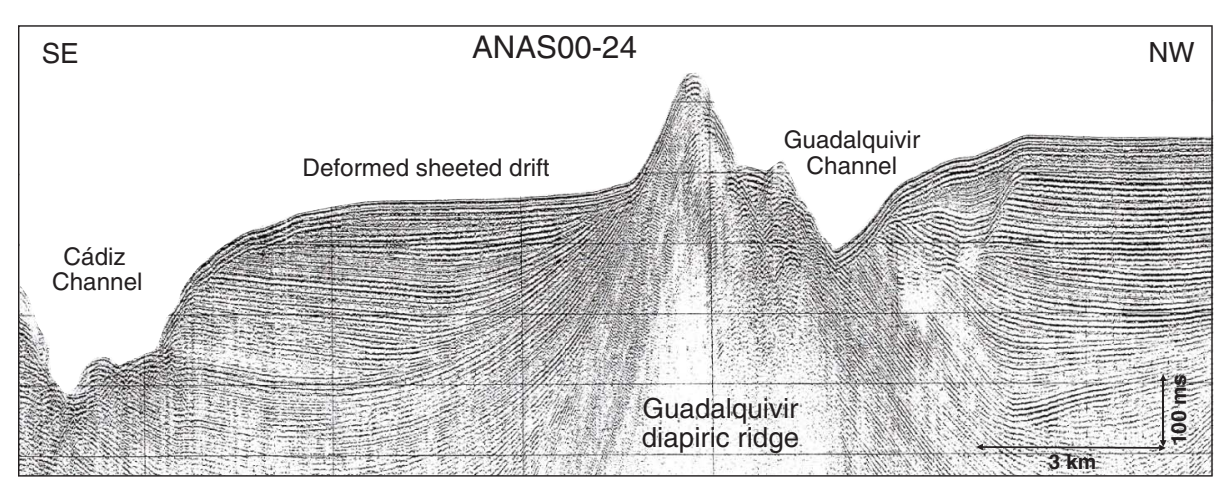

D

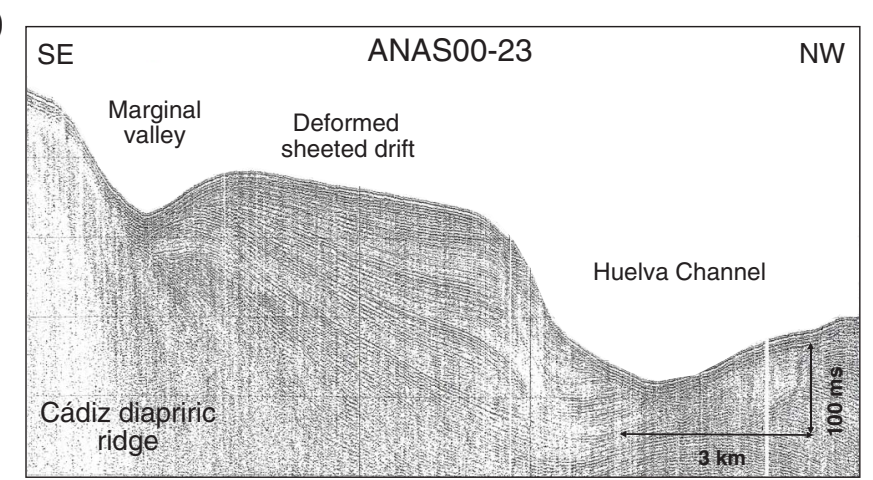

C

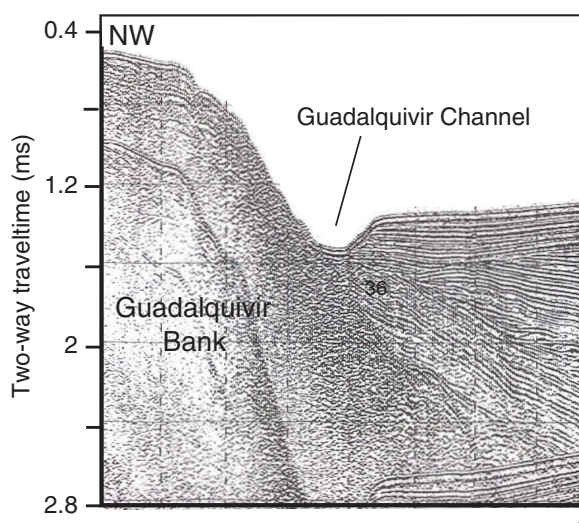

E

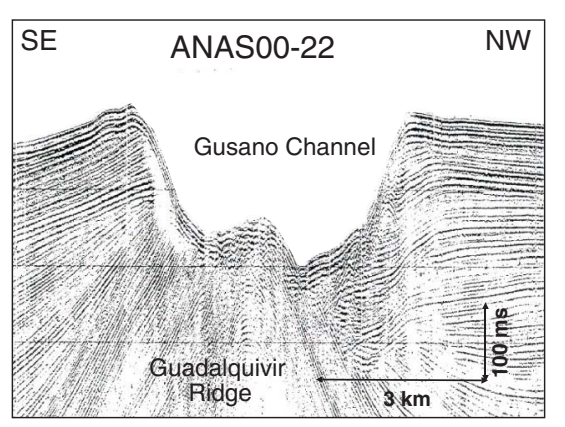

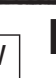

$\mathbf{F}$

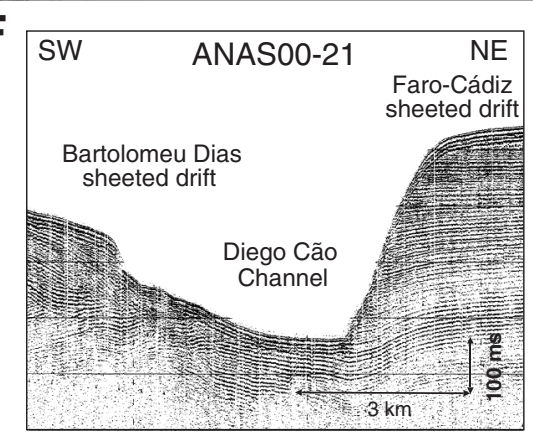

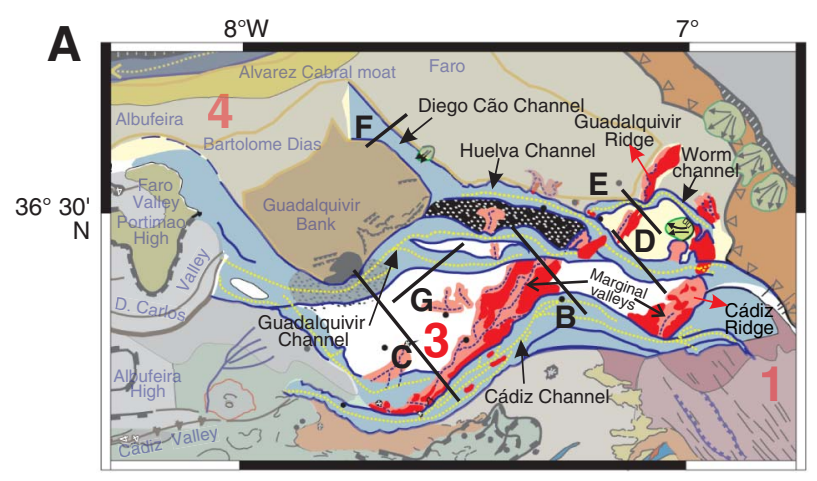
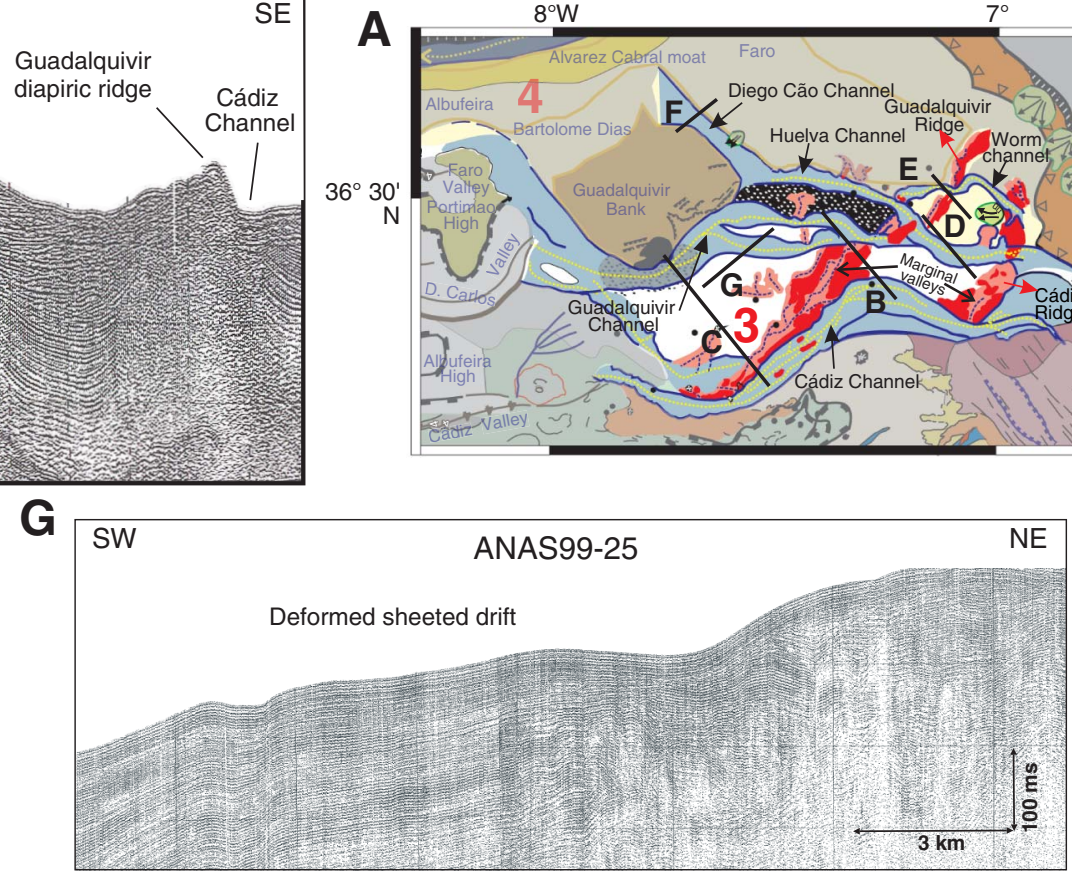

G 
Figure F6. Seismic profiles across the middle slope, Site U1389 (from Llave et al., 2007b). QD = Intra Quaternary discontinuity, MPR = mid-Pleistocene revolution discontinuity, Q-I and Q-II = depositional sequences. A, B. Uninterpreted multichannel seismic reflection profile across the middle slope, Site U1389 (provided by REPSOL-YPF Oil Company). C. High-resolution sparker seismic profile through part of the Huelva buried mounded drift of the northern and eastern area of the central sector of the middle slope.

A

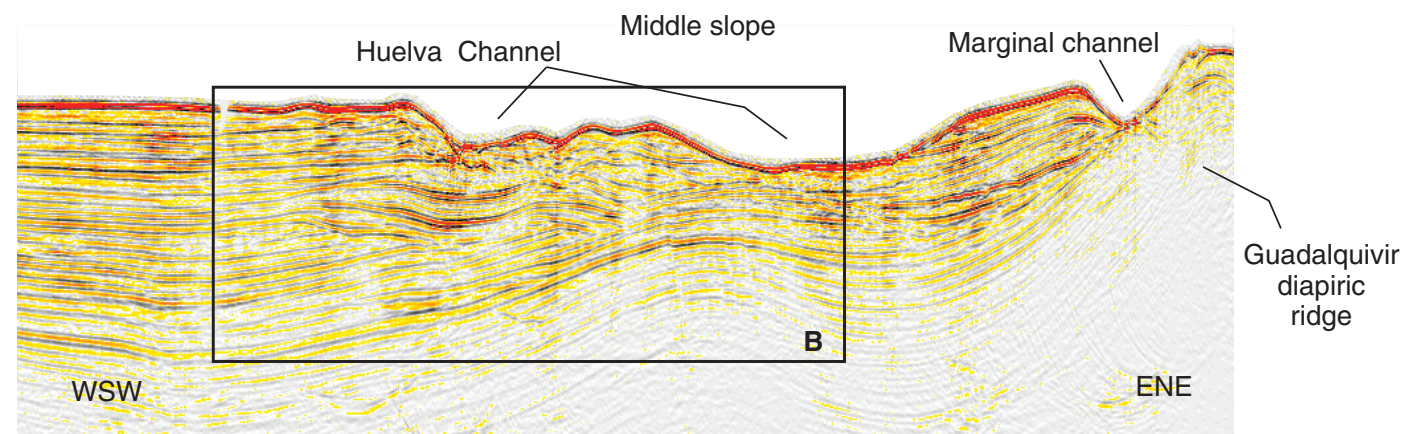

B
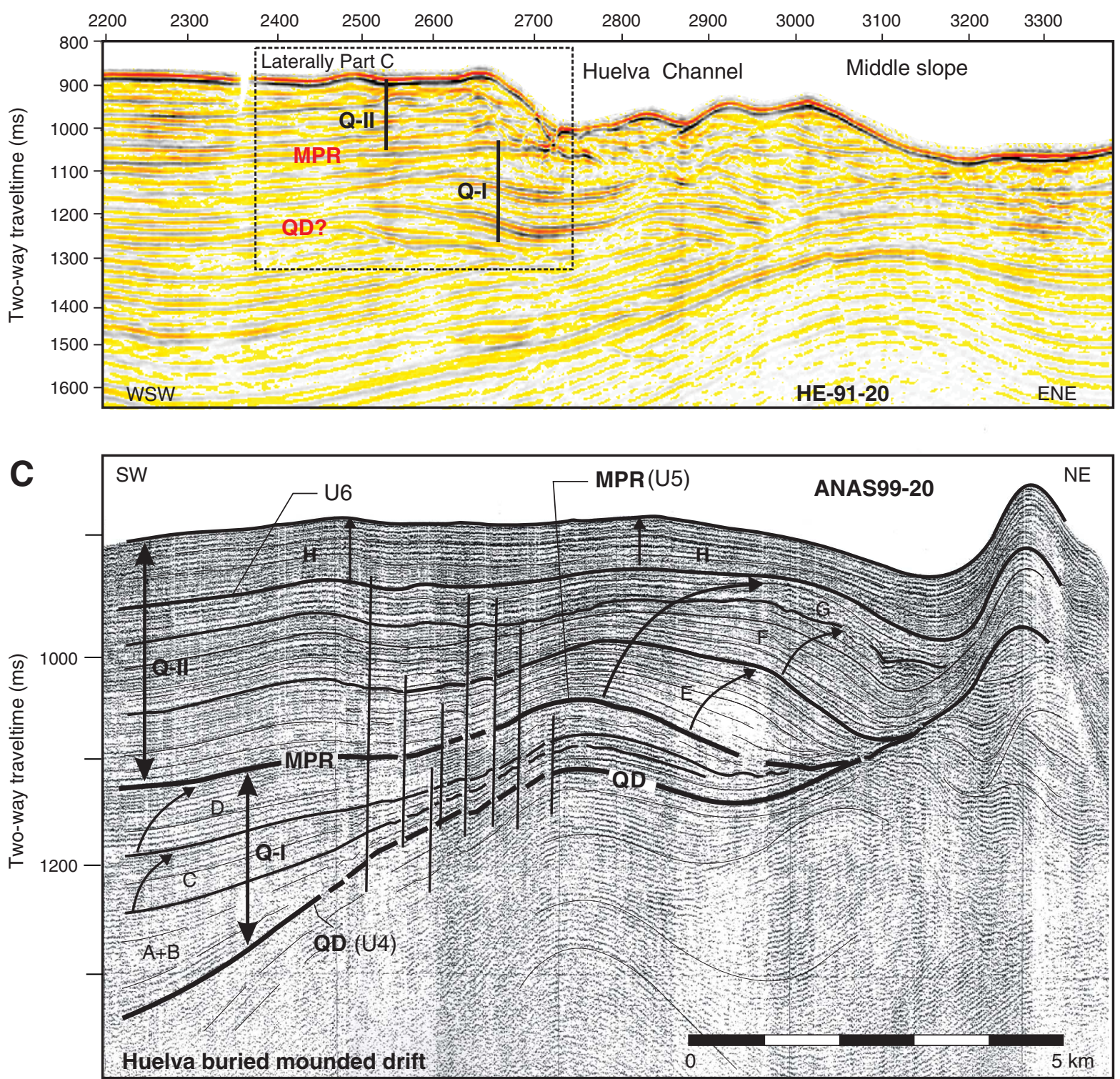
Figure F7. Interpretative sketches of the Quaternary evolution of the buried mounded drift deposits in the channels and ridges sector of the middle slope of the Gulf of Cádiz (from Llave et al., 2007b). GB = Guadalquivir Bank, DDR = Doñana diapiric ridge, GDR = Guadalquivir diapiric ridge, $\mathrm{CDR}=$ Cádiz diapiric ridge. A. Overview of the oceanographic patterns in the Gulf of Cádiz. MOW = Mediterranean Outflow Water, MU = Mediterranean upper water, $\mathrm{ML}=$ Mediterranean lower water, $\mathrm{IB}=$ intermediate branch, $\mathrm{PB}=$ principal branch, $\mathrm{SB}=$ southern branch. $\mathrm{Square}$ with discontinuous lines represent the area for B,C and D reconstructions. B. Active Guadalquivir and Huelva Drift growth stage (early to mid-Pleistocene) C. Late-stage drift growth (mid- to late Pleistocene). D. Complete drift burial (late Pleistocene and Holocene) when the present morphologic configuration of this sector was generated by new oceanographic conditions of ML.
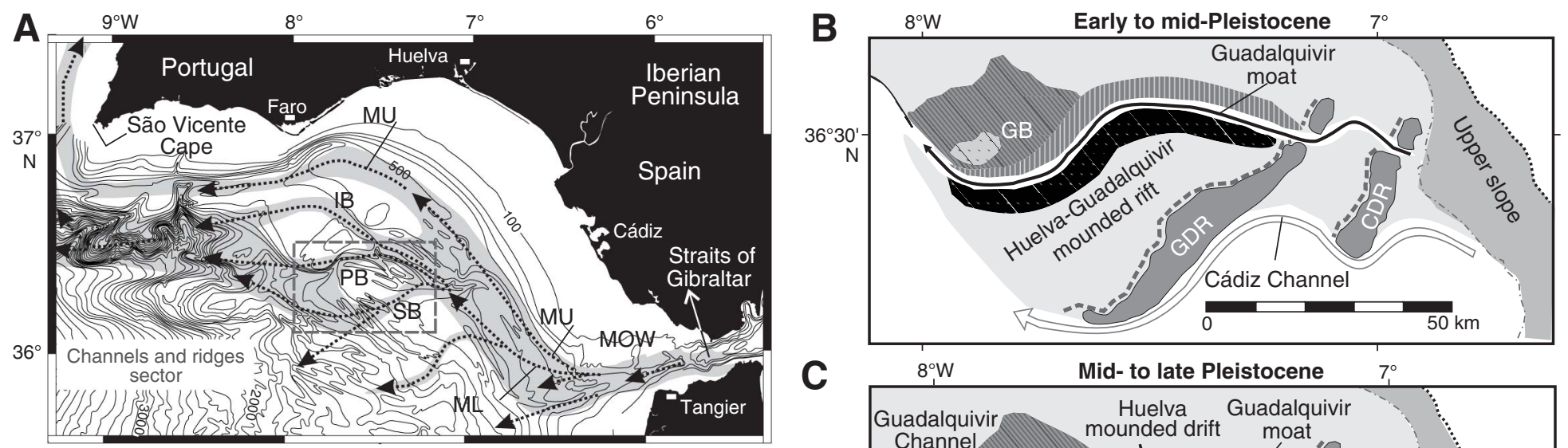

Upper slope

Erosional area

Elongate, mounded and separate drift Sheeted drift

VIIIIS Deformed laminar drift

Present shelf break Present upper slope
distal limit distal limit

$\longleftarrow$ Contouritic moat

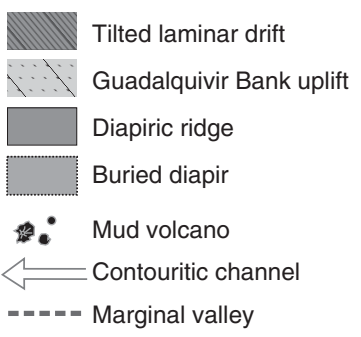

Contouritic channel =---- Marginal valley
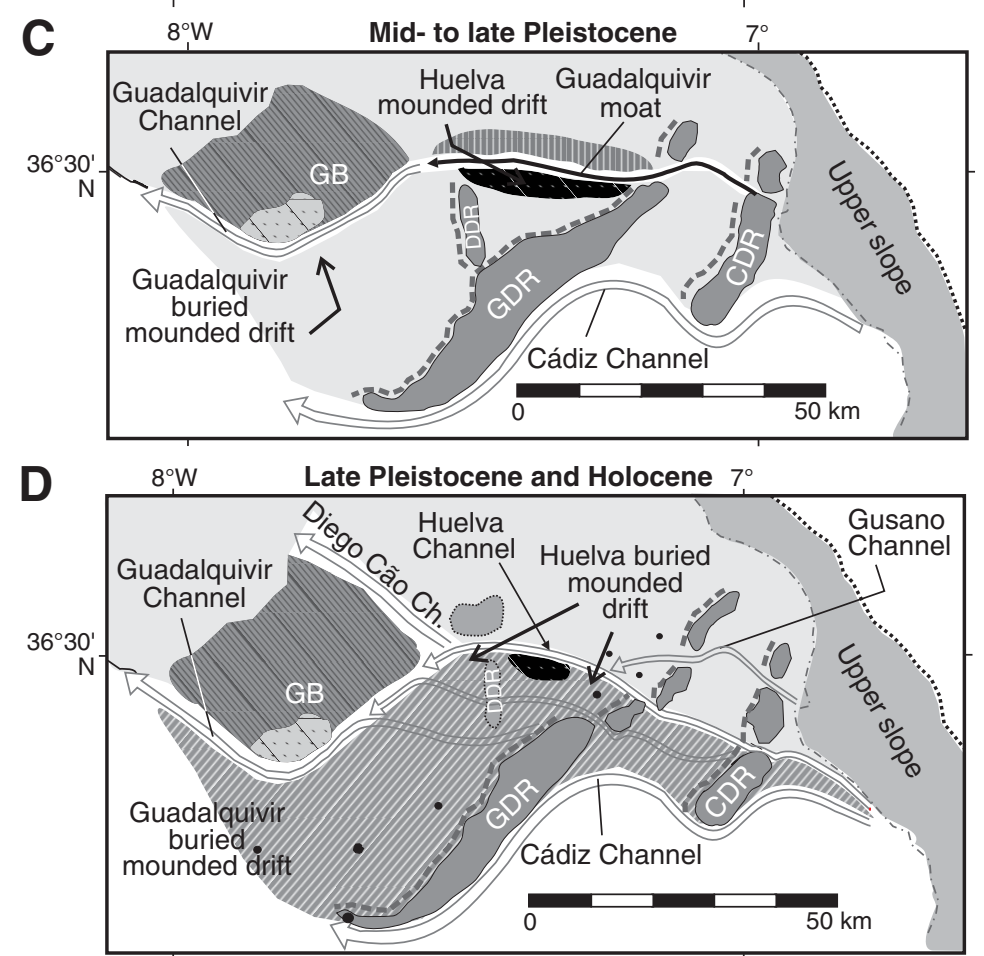
Figure F8. Graphic lithology summary log, Site U1389.

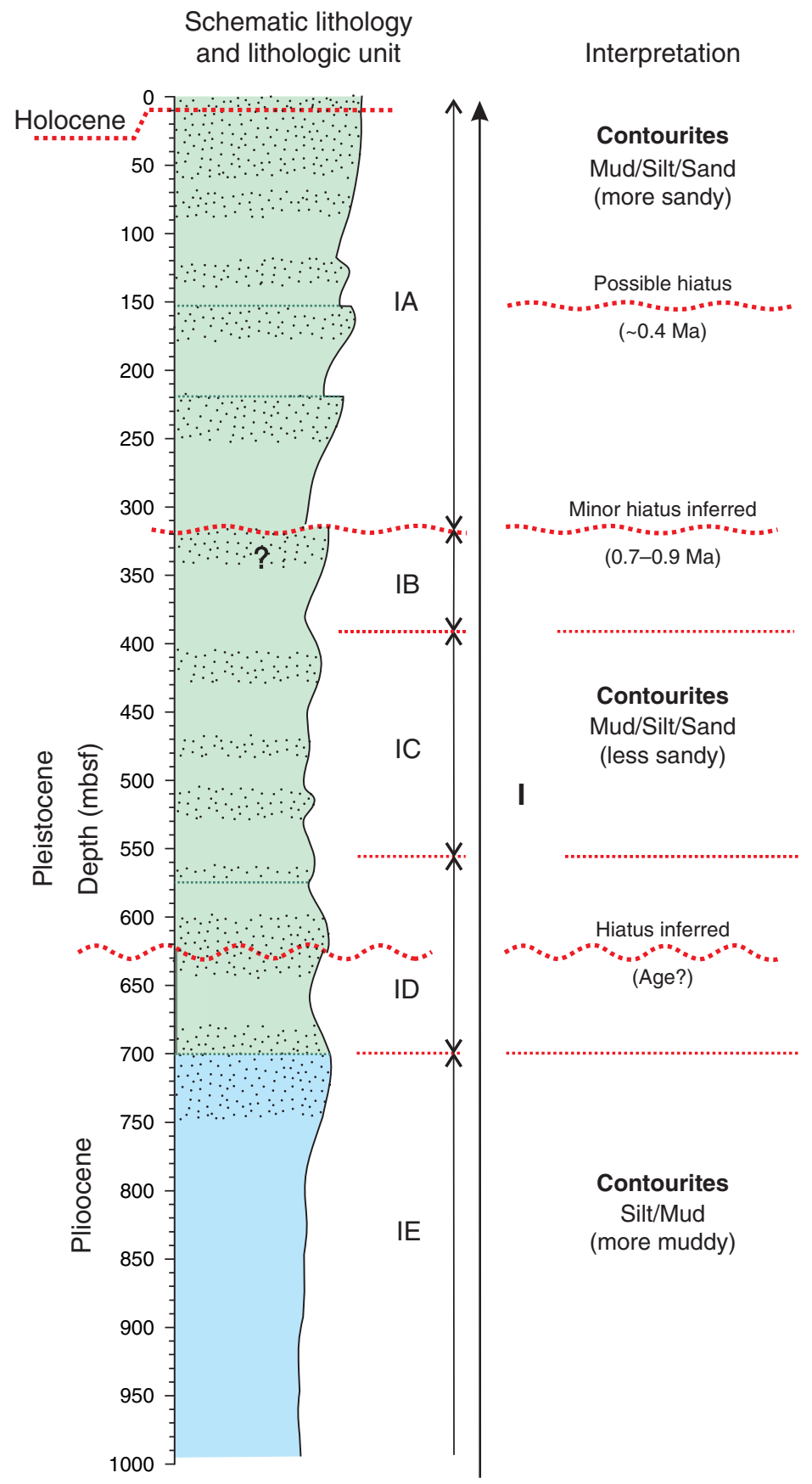


Figure F9. Plot of downhole variations in lithology, Site U1389.

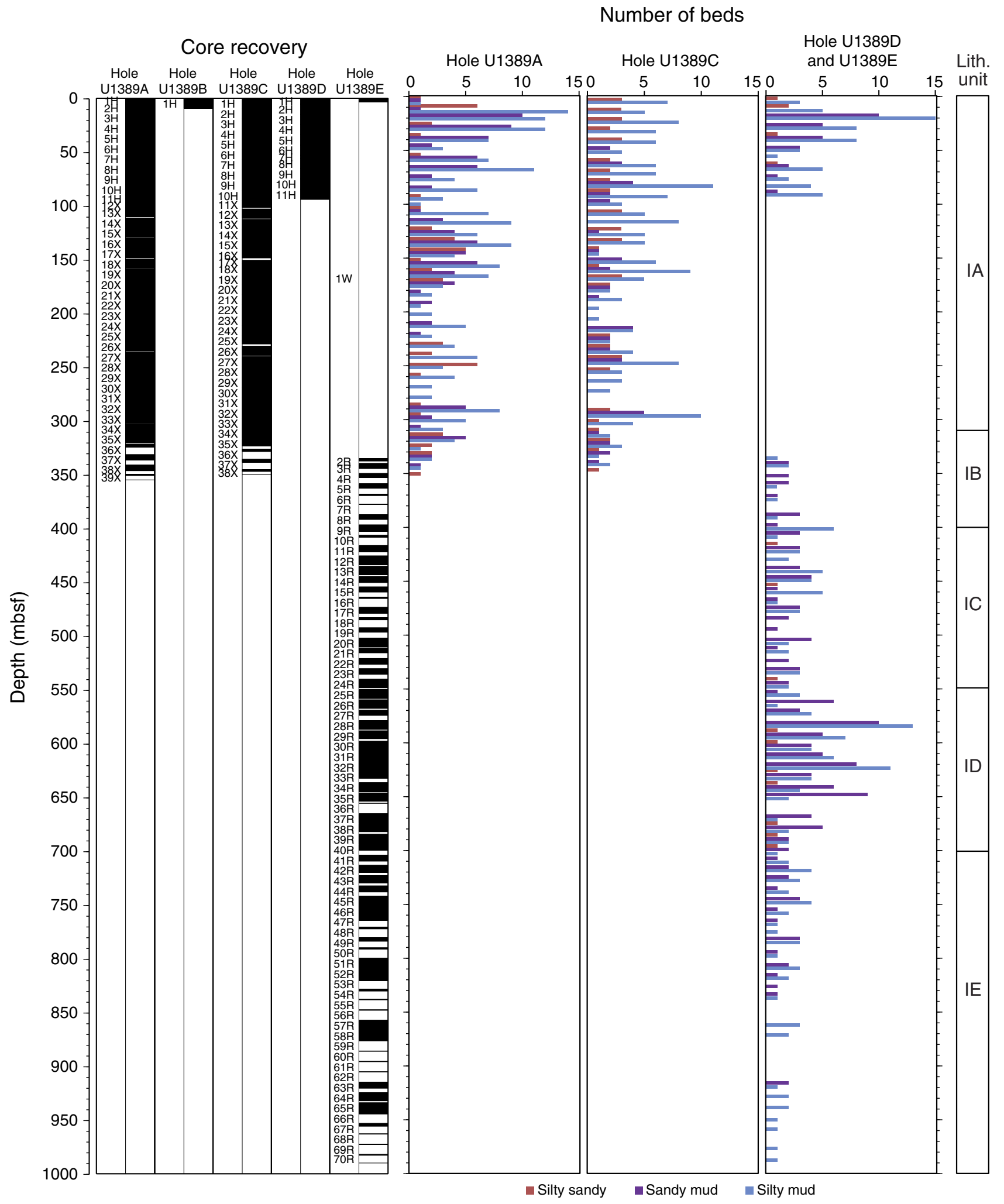


Figure F10. Plot showing downhole trends in the number and composition of beds, Site U1389.

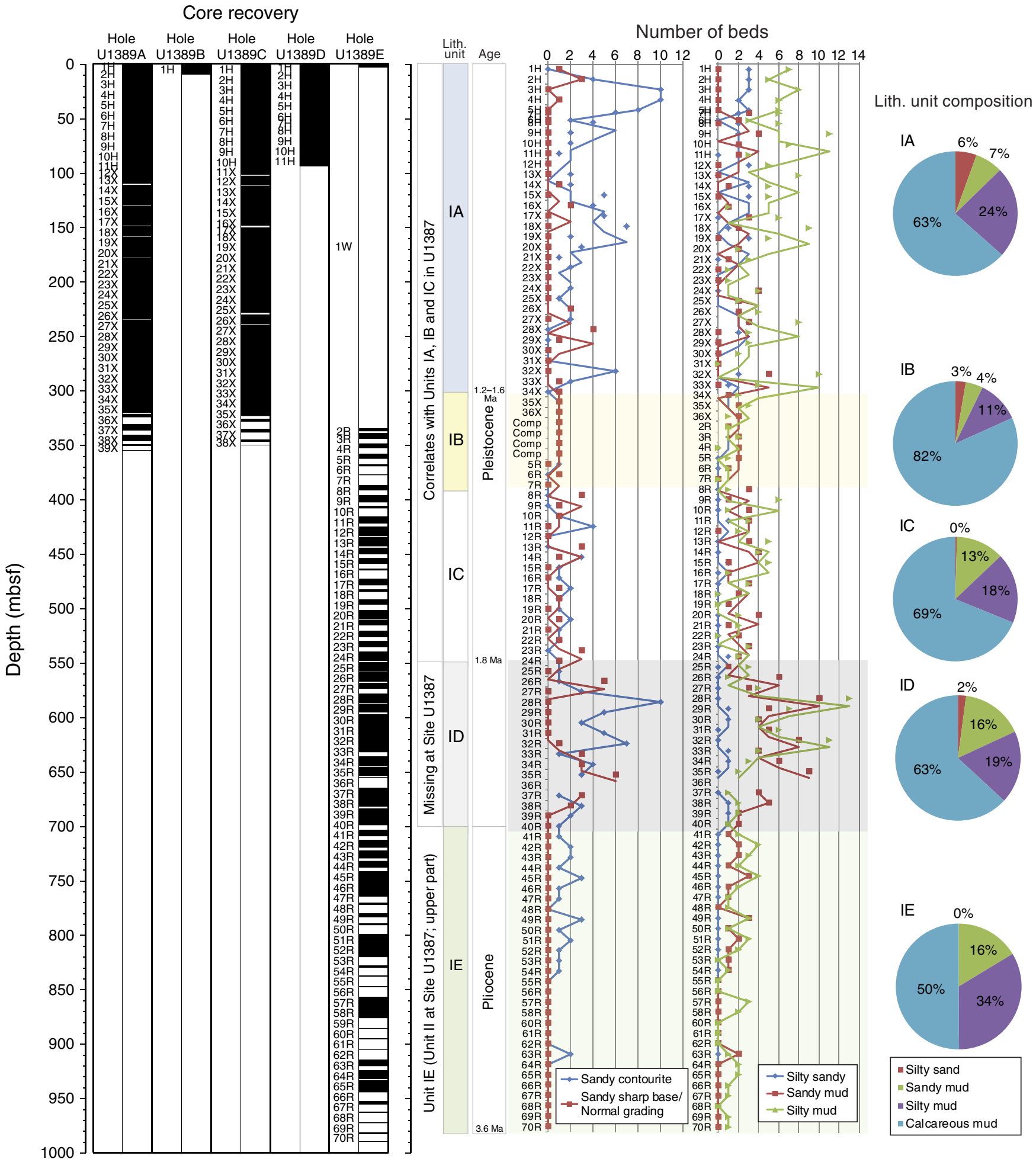


Figure F11. Graphic lithology summaries, Site U1389. A. Hole U1389A. (Continued on next four pages.)

A

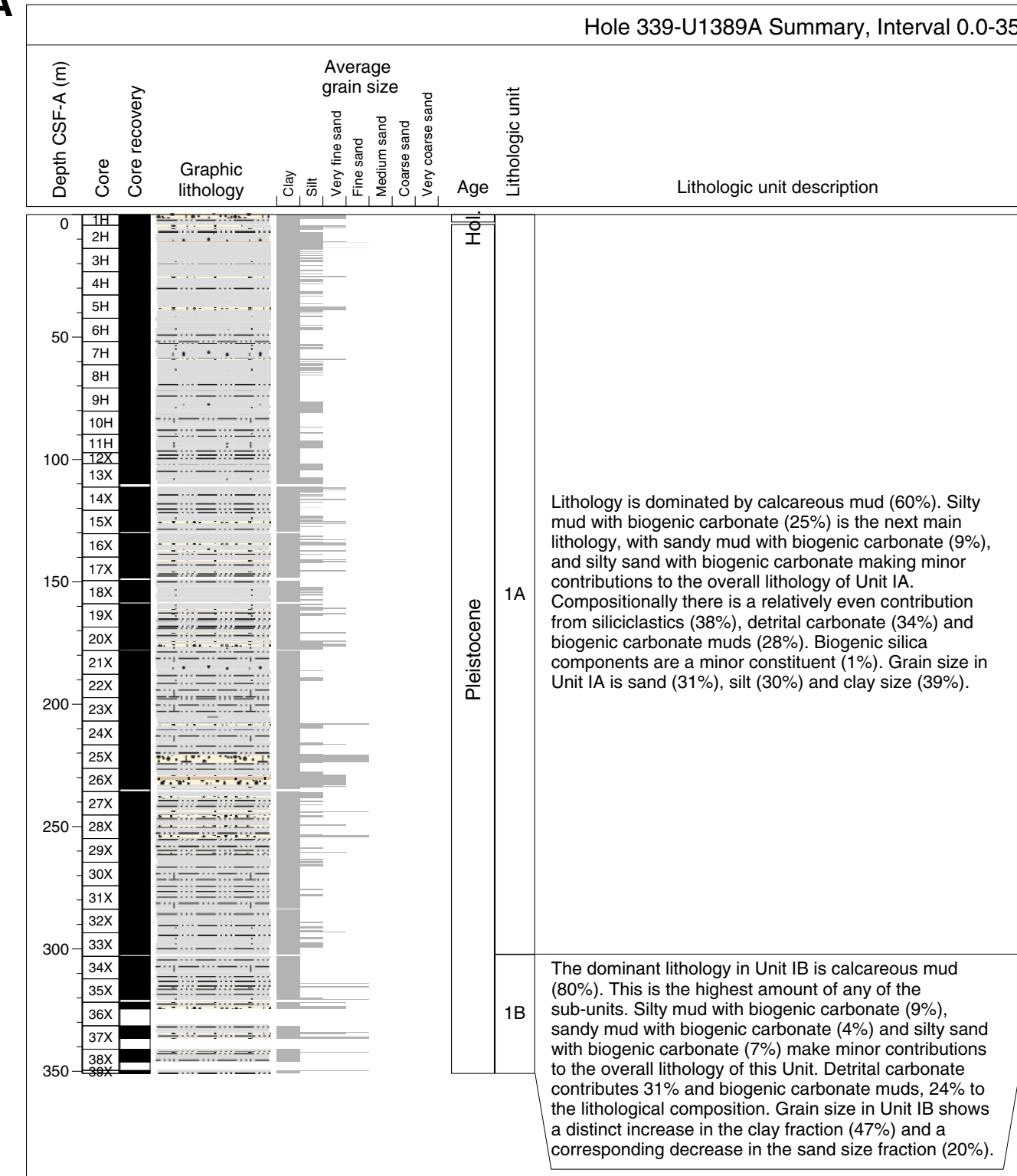

$350.9 \mathrm{~m}$ (CSF-A)

$$
\begin{aligned}
& \text { Magnetic } \\
& \text { susceptibility } \\
& \text { (SI) }
\end{aligned}
$$

GRA
bulk density bulk density
$\left(\mathrm{g} / \mathrm{cm}^{3}\right)$ Color
reflectance
$\mathrm{L}^{*}$ 운

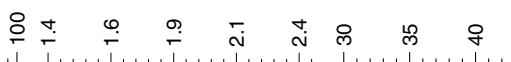
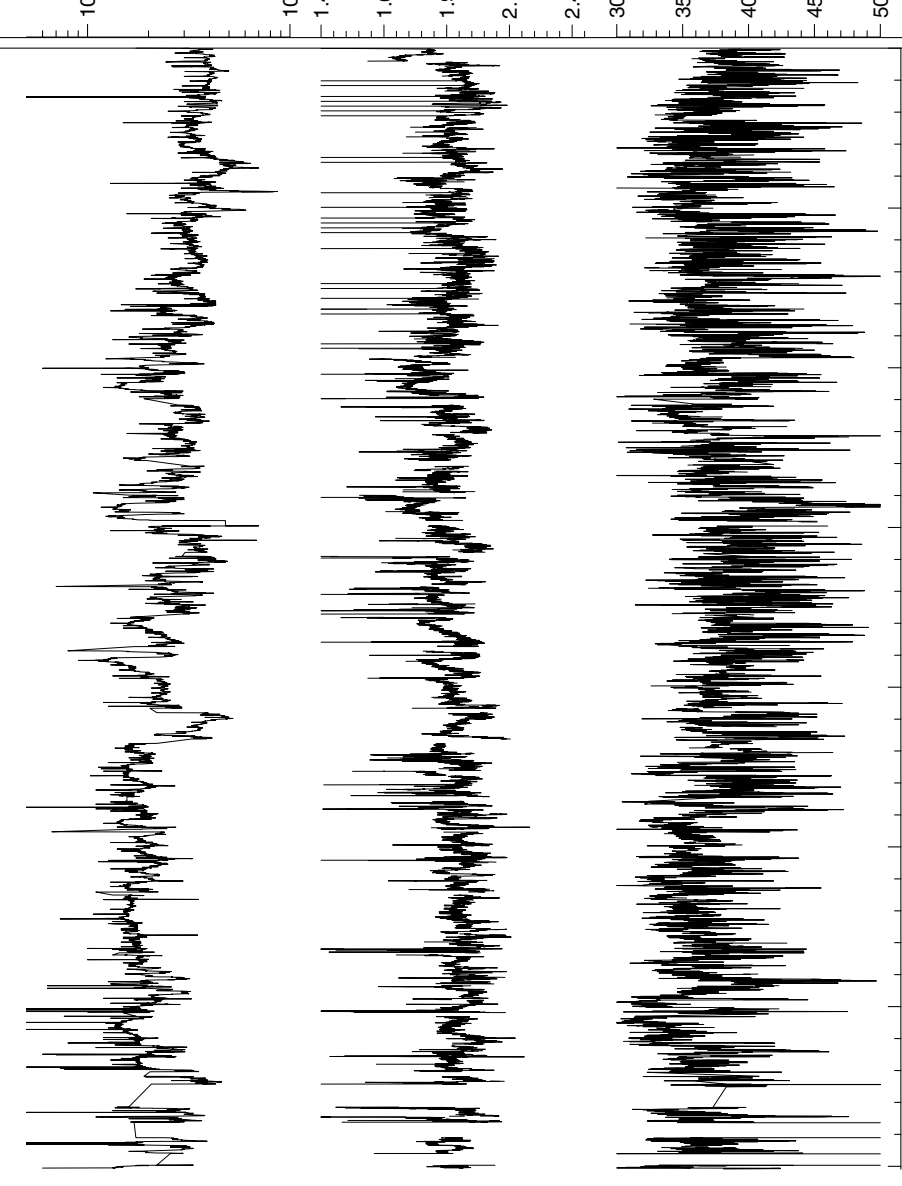
Figure F11 (continued). B. Hole U1389B. (Continued on next page.)

B

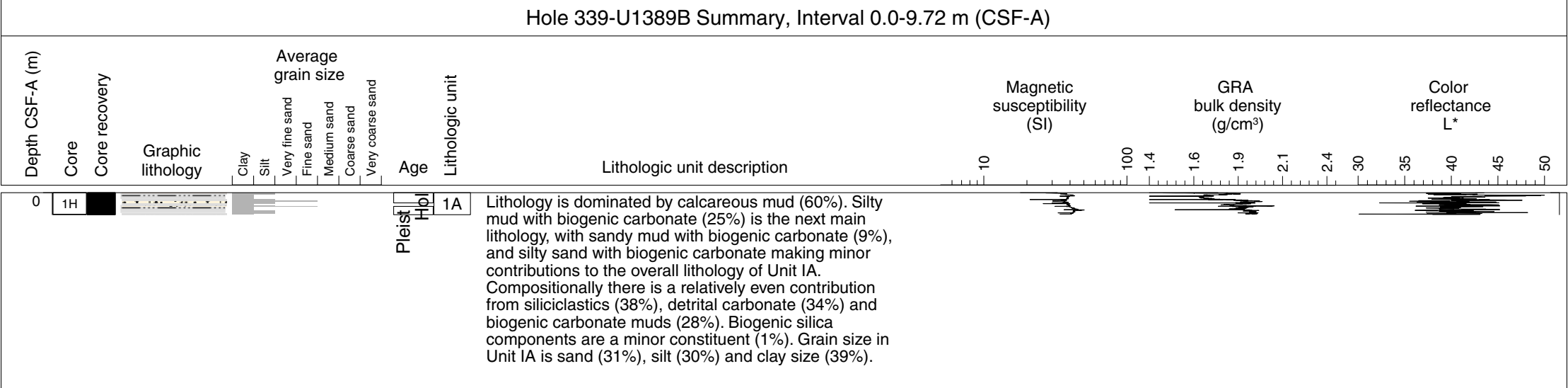


Figure F11 (continued). C. Hole U1389C. (Continued on next page.)

C

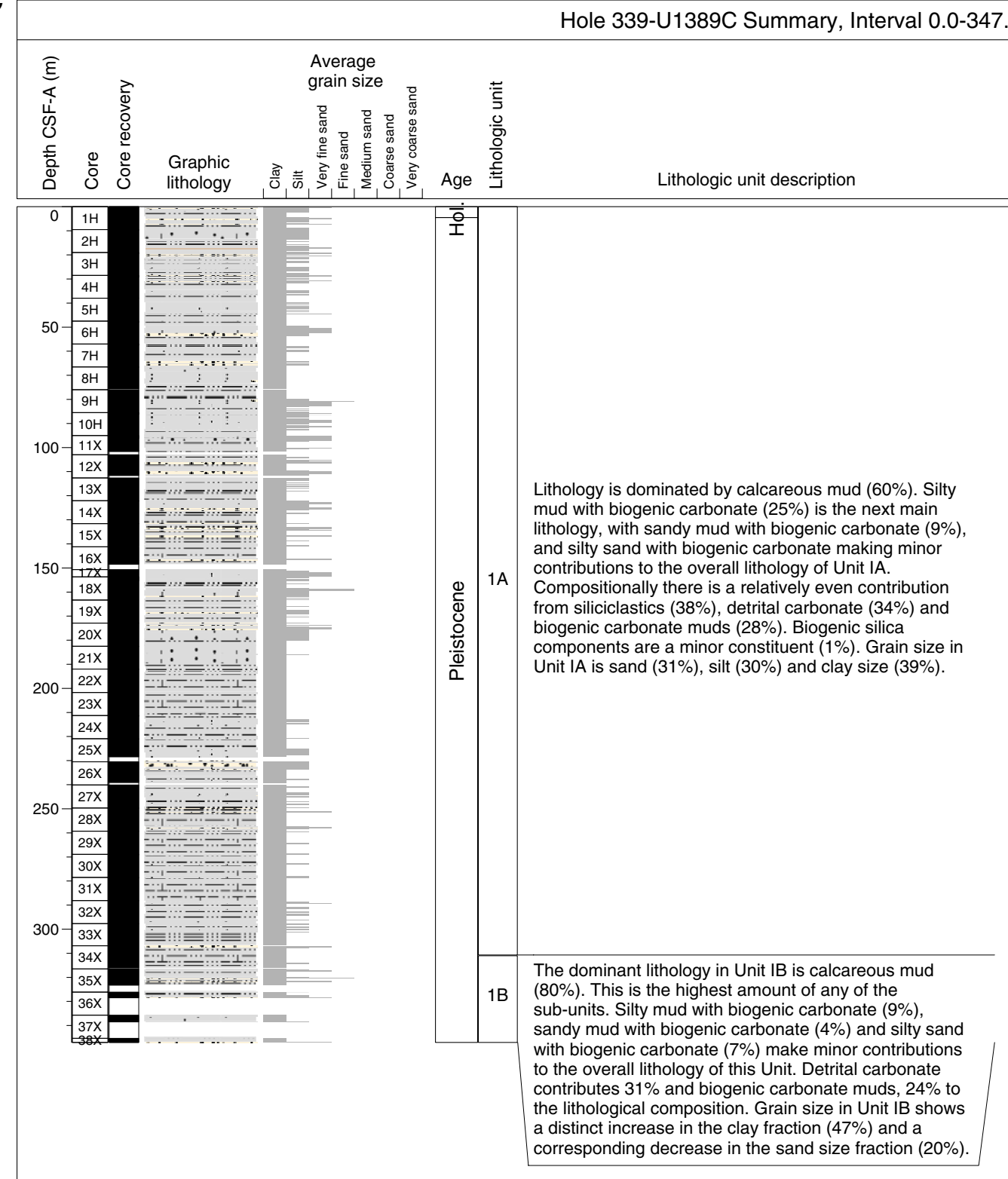

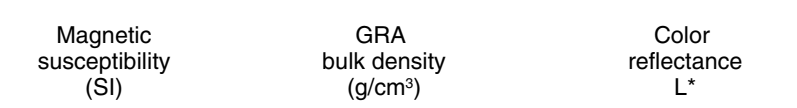

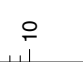
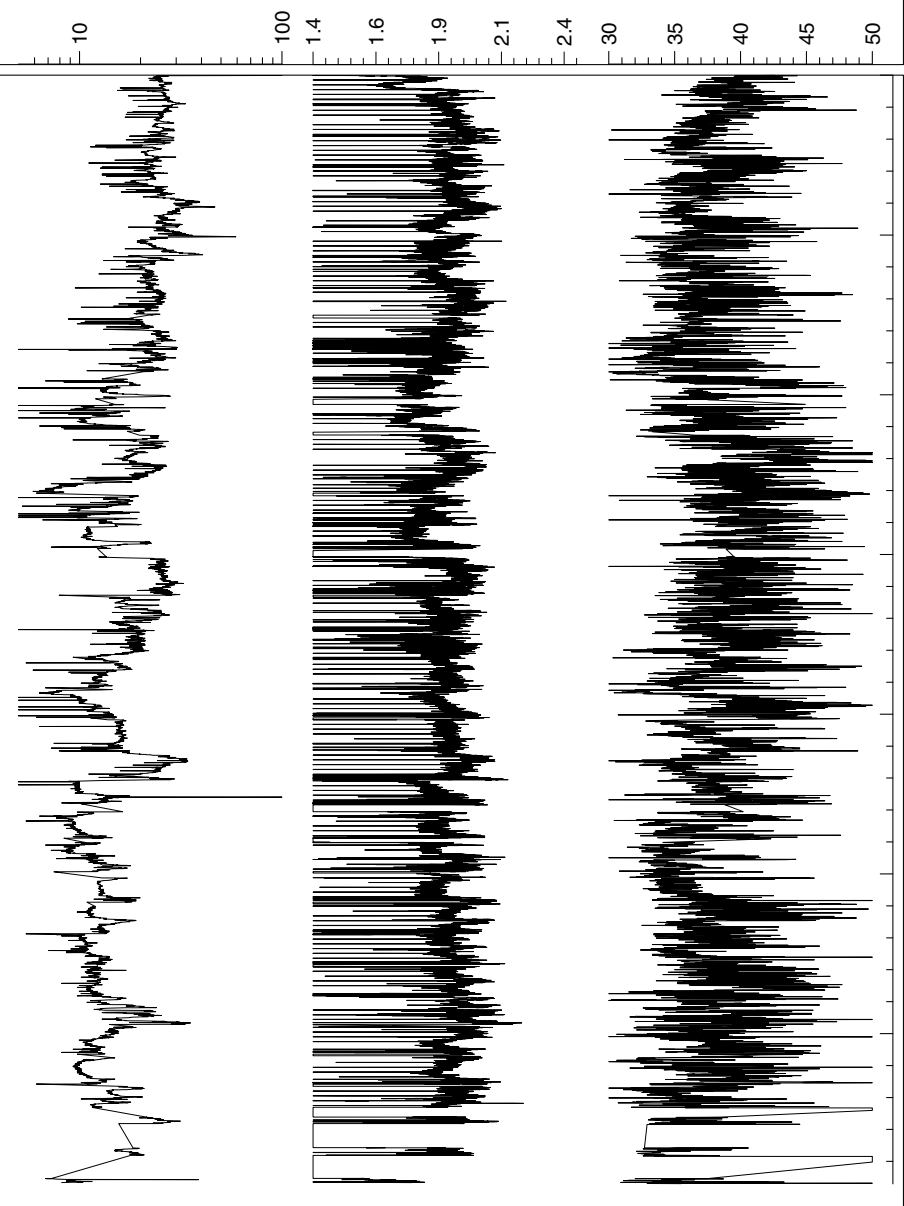
Figure F11 (continued). D. Hole U1389D. (Continued on next page.)

D

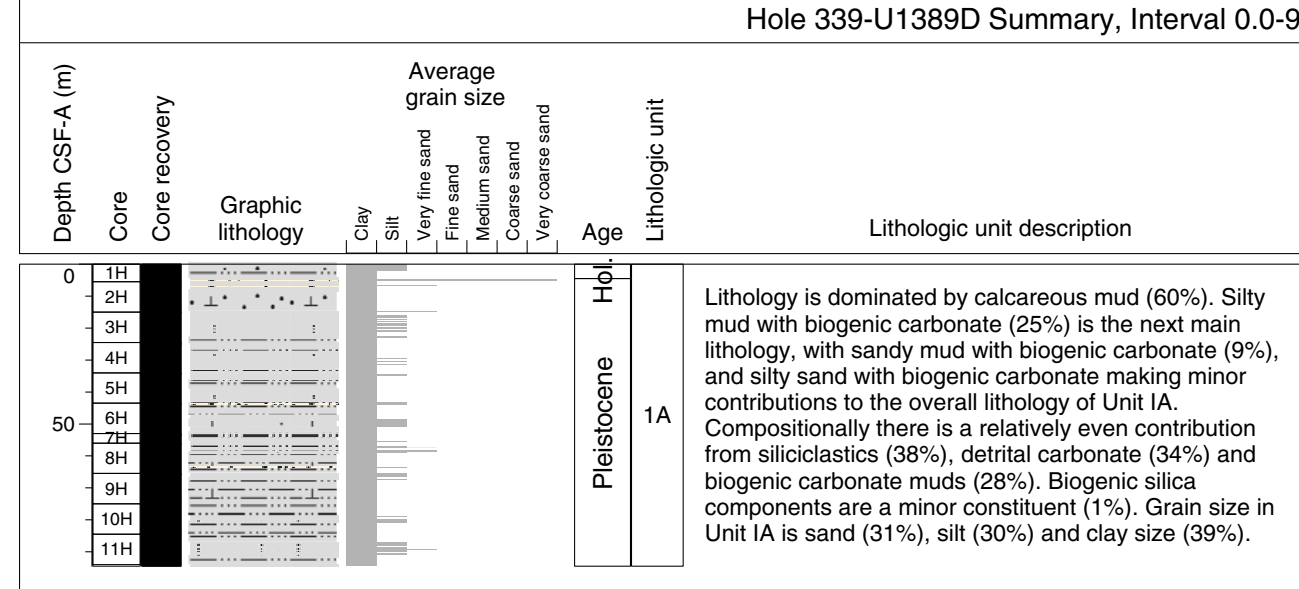

$\begin{array}{ccc}\begin{array}{c}\text { Magnetic } \\ \text { susceptibility }\end{array} & \text { GRA } & \text { Color } \\ (\mathrm{SI}) & \text { bulk density } & \text { reflectance } \\ \left(\mathrm{g} / \mathrm{cm}^{3}\right) & \mathrm{L}^{*}\end{array}$

ำ

$\stackrel{\circ}{\circ}$

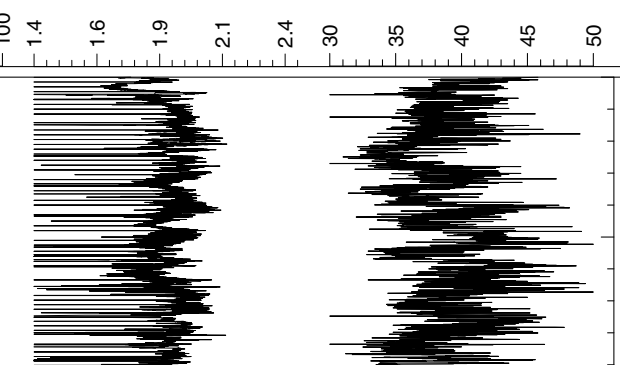


Figure F11 (continued). E. Hole U1389E.

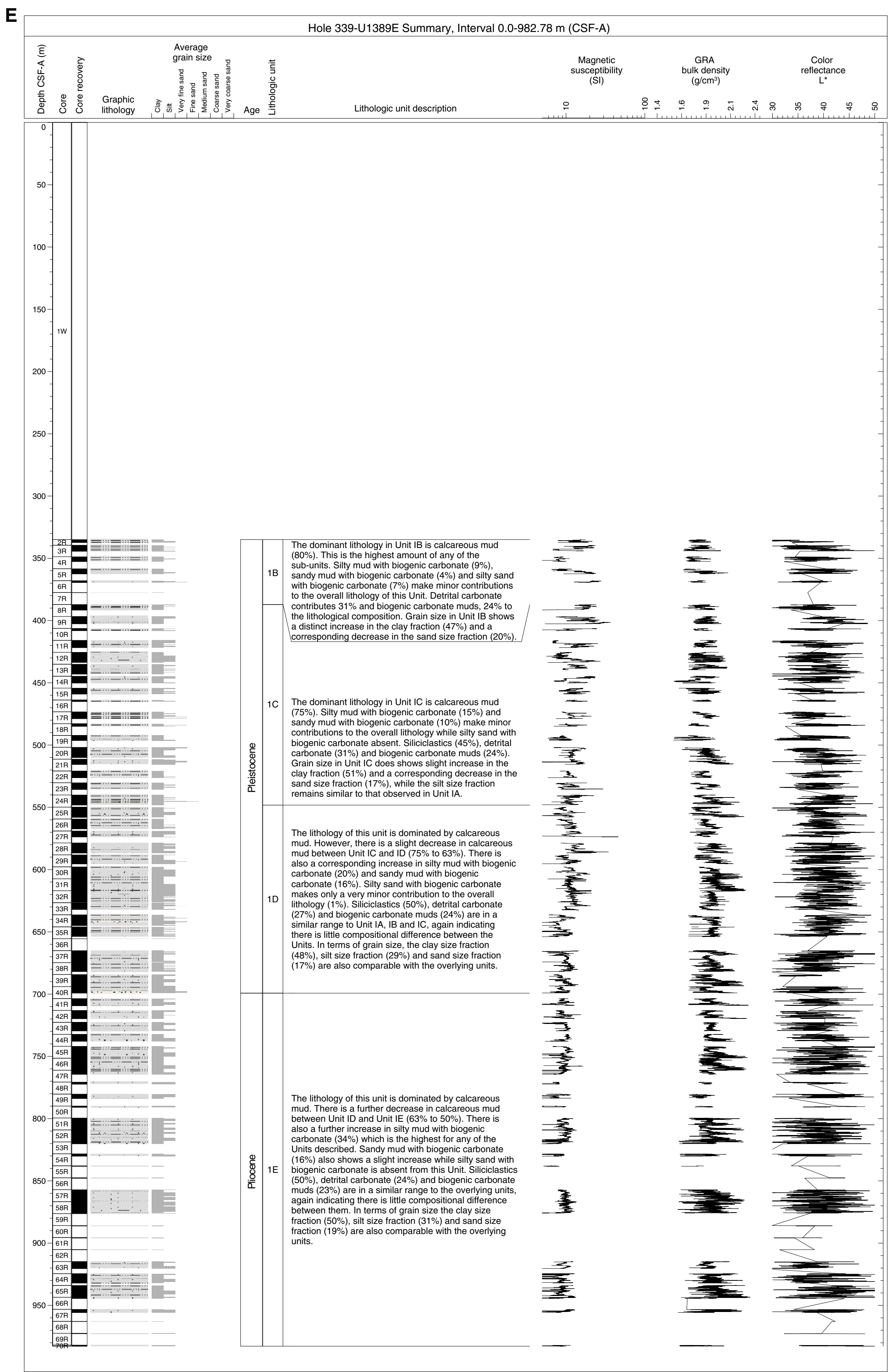


Figure F12. Core images of bi-gradational sequence (Section 339-U1389C-32X-1).
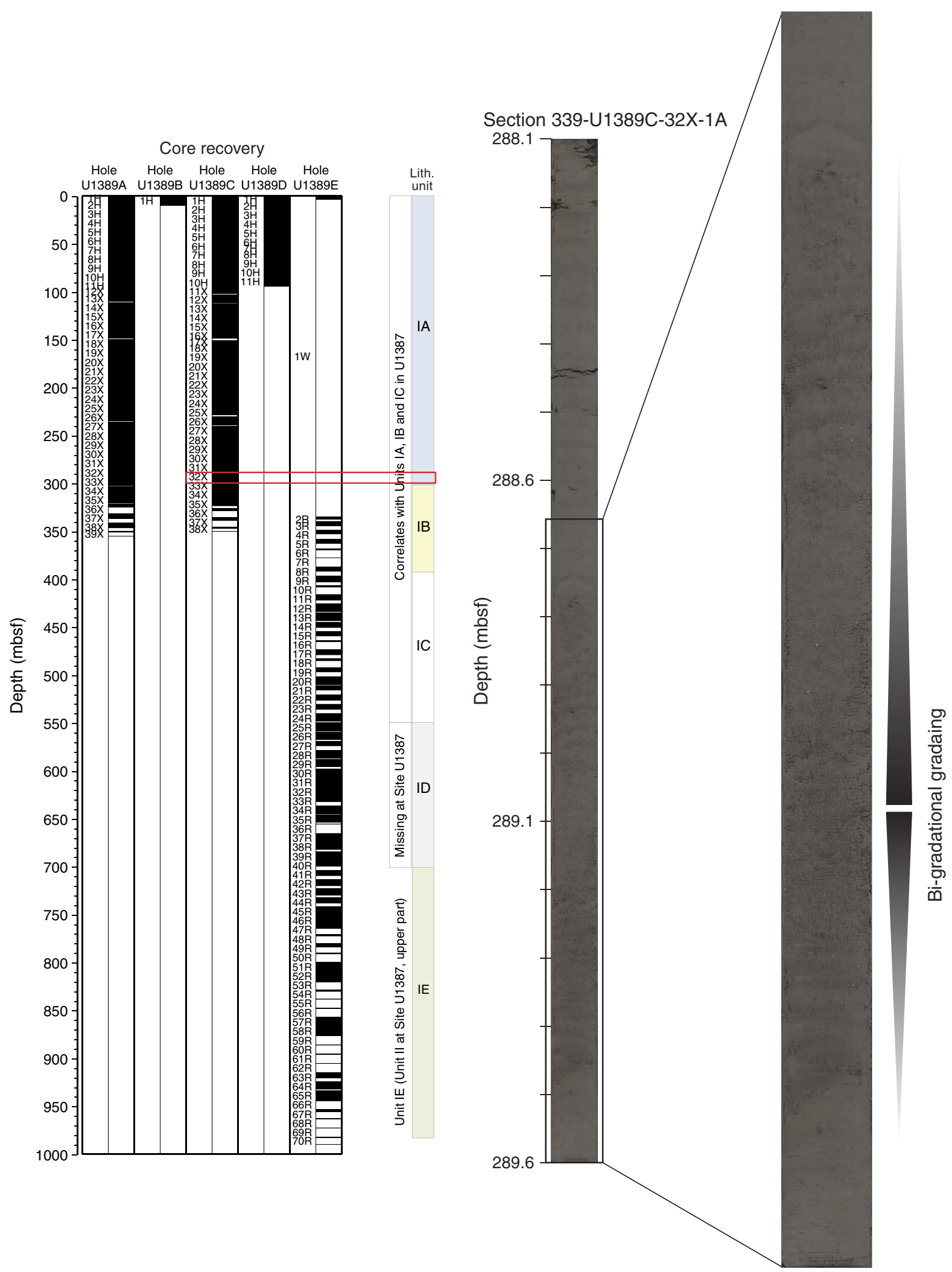
Figure F13. Core images of normal grading (Section 339-U1389C-32X-4).

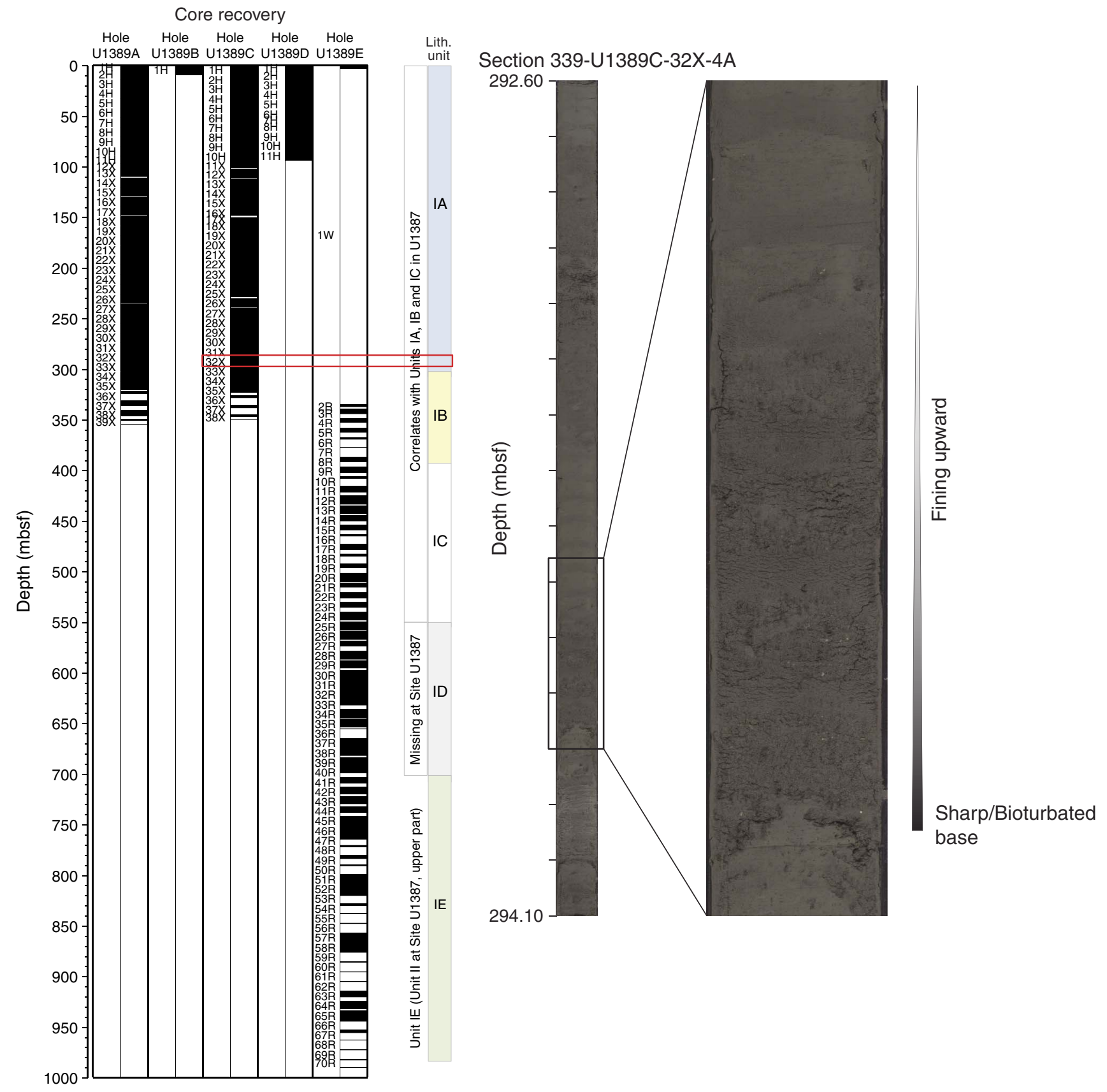



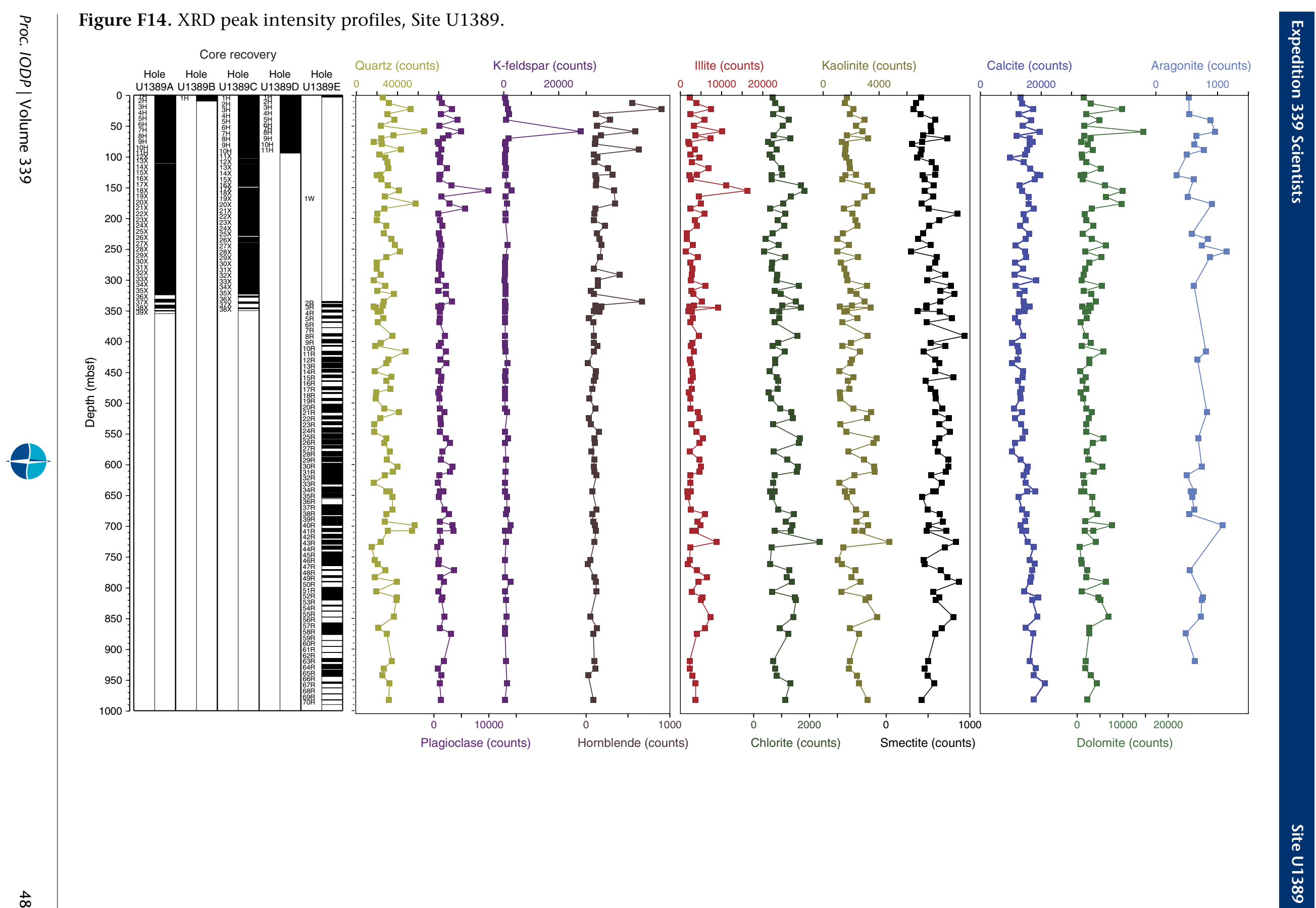
Figure F15. Photographs of identified macrofauna (gastropods), Site U1389.
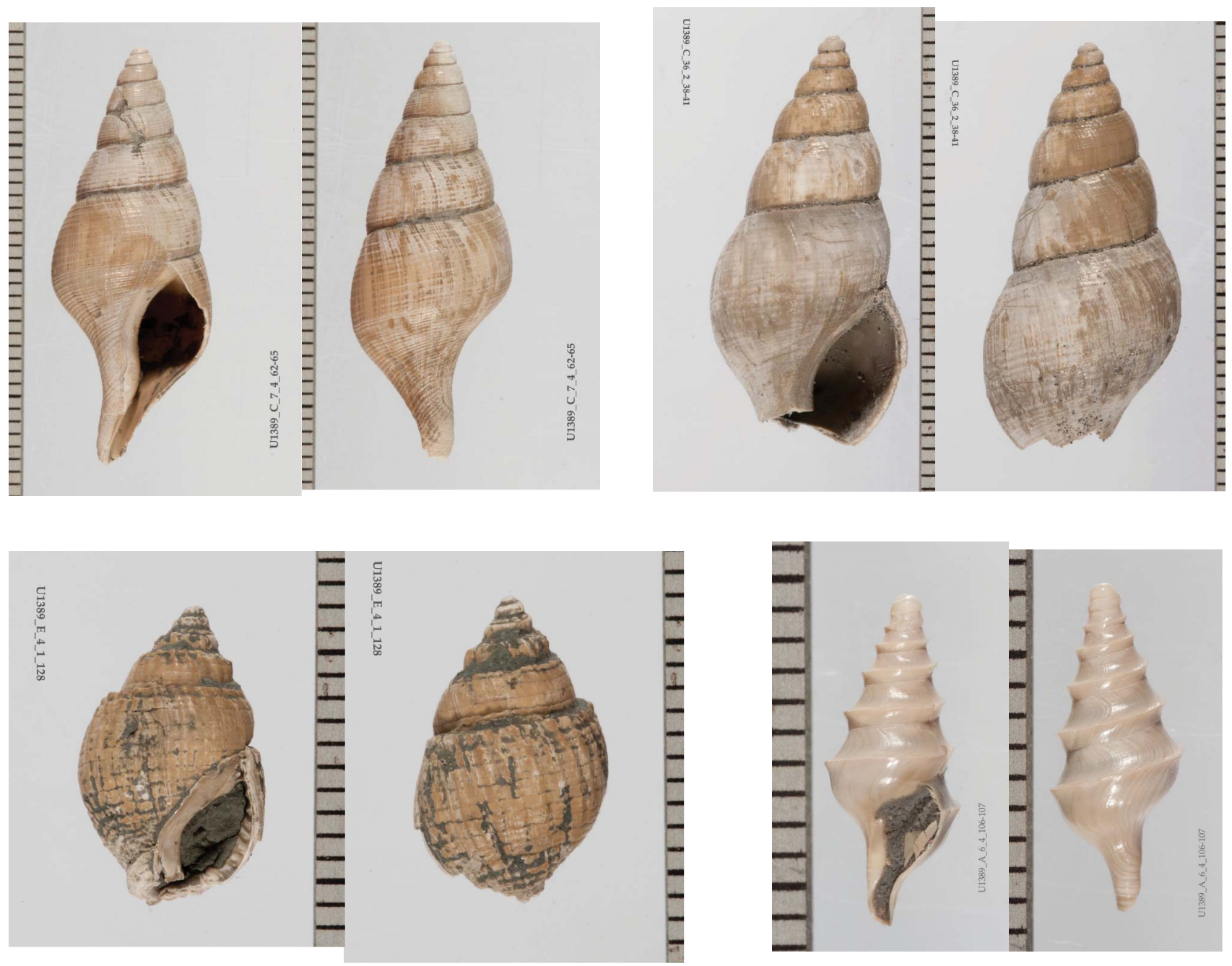

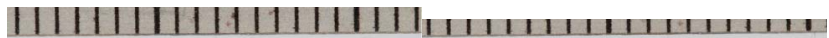

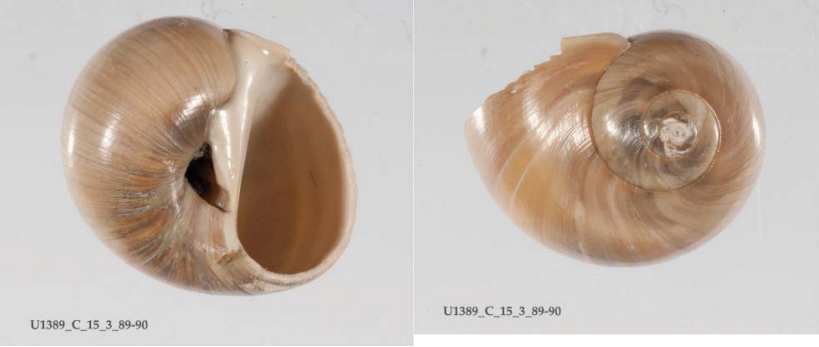


Figure F16. Photographs of identified macrofauna, Site U1389. A. Fragment of a large bivalve. B. Shell fragments. C. Arenaria. D. Sea urchin fragments. E. Sea urchin spines. F-H. Cold-water coral.

A

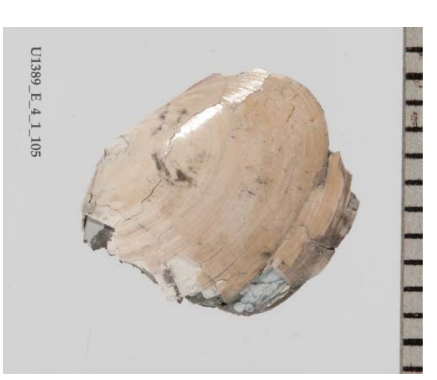

D
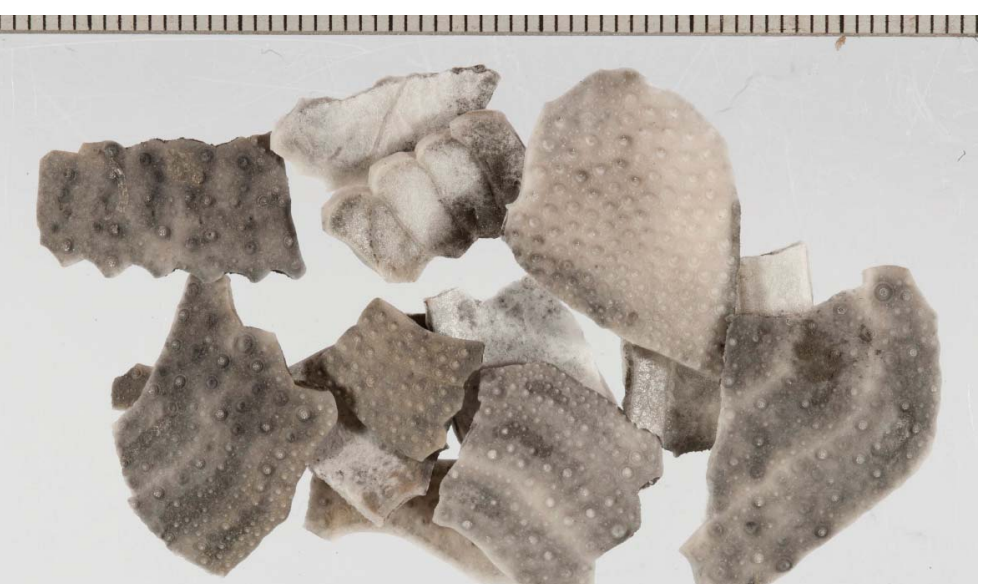

U1389_B_1_6_62-64

(27)

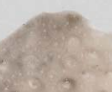

B

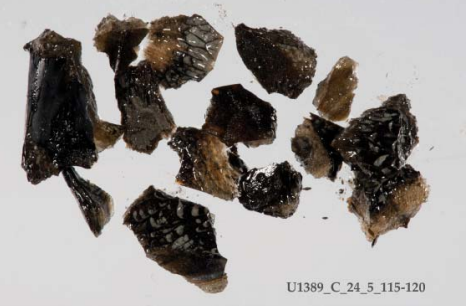

E

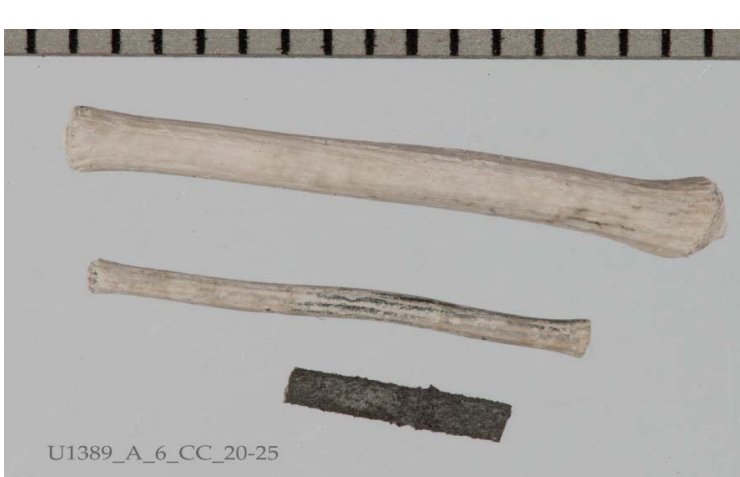

G

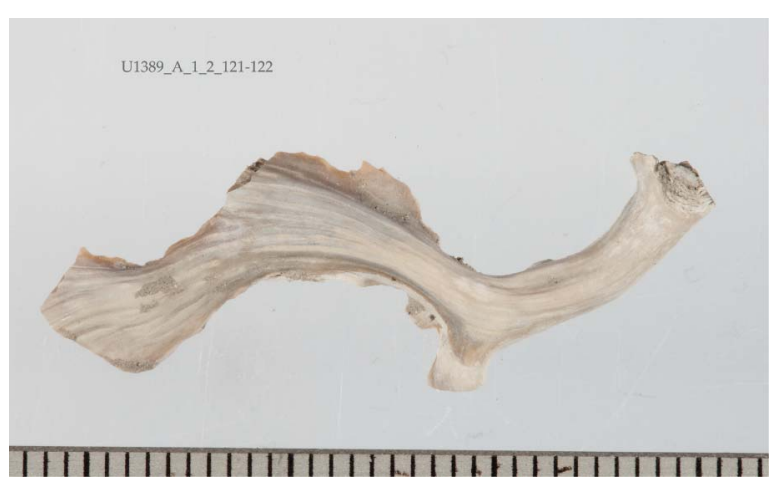

C

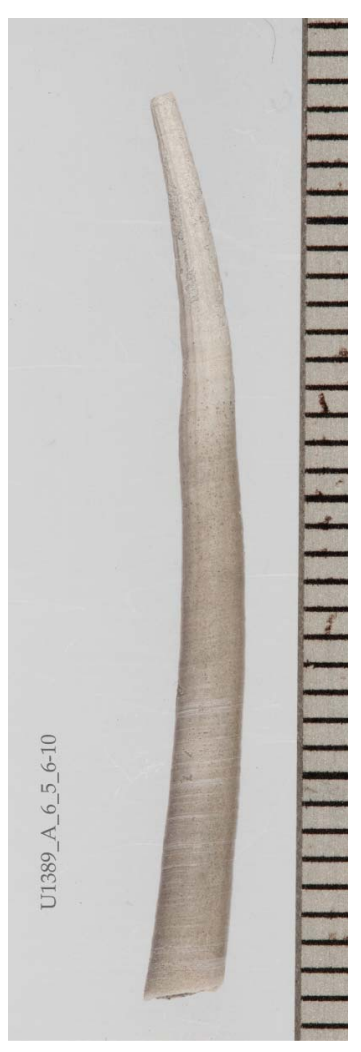

F 11111111111111

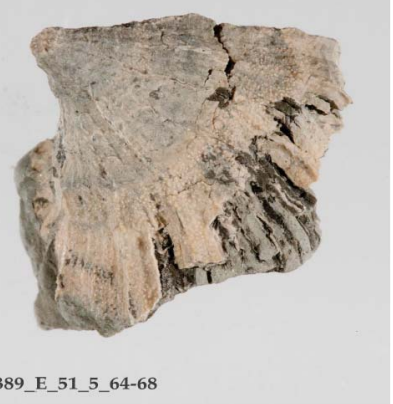

H

$11+1111111111111111111$

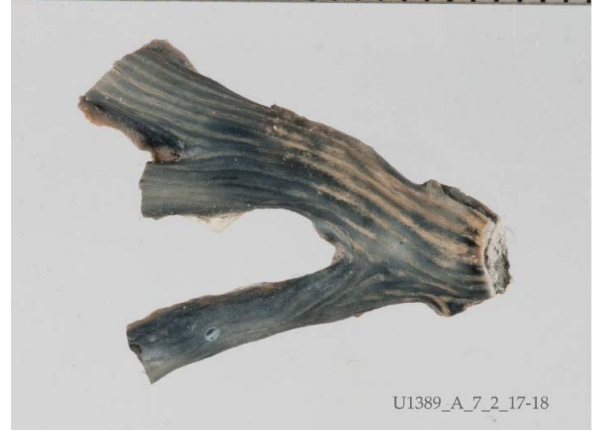


Figure F17. Core image of Arenaria colony (interval 339-U1389A-13X-5, 78-88 cm).

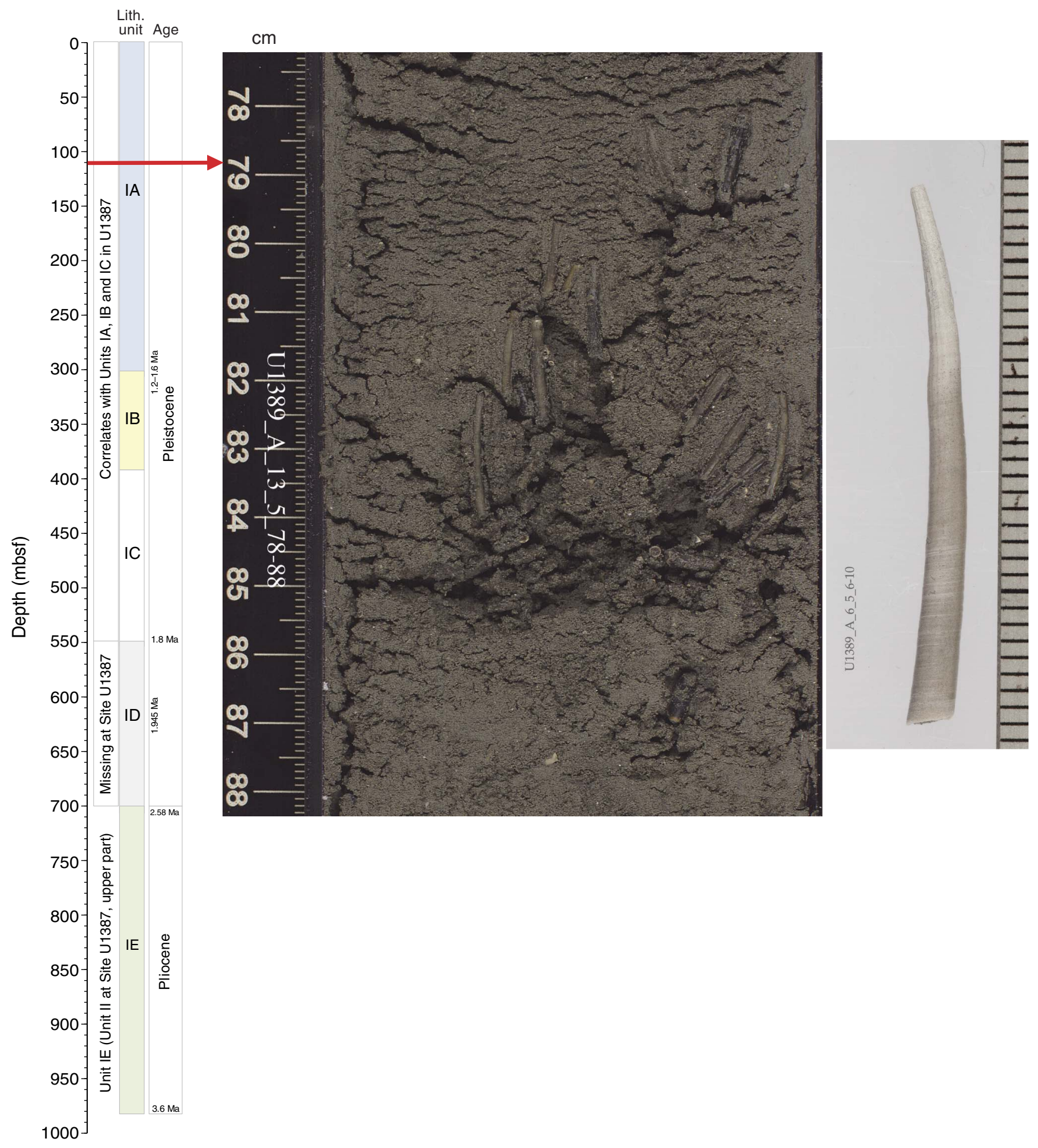


Figure F18. Core images of ichnofossils (Sections 339-U1389E-26R-1 and 26R-3). A. Large silt-filled burrow. B. Spirophyton.

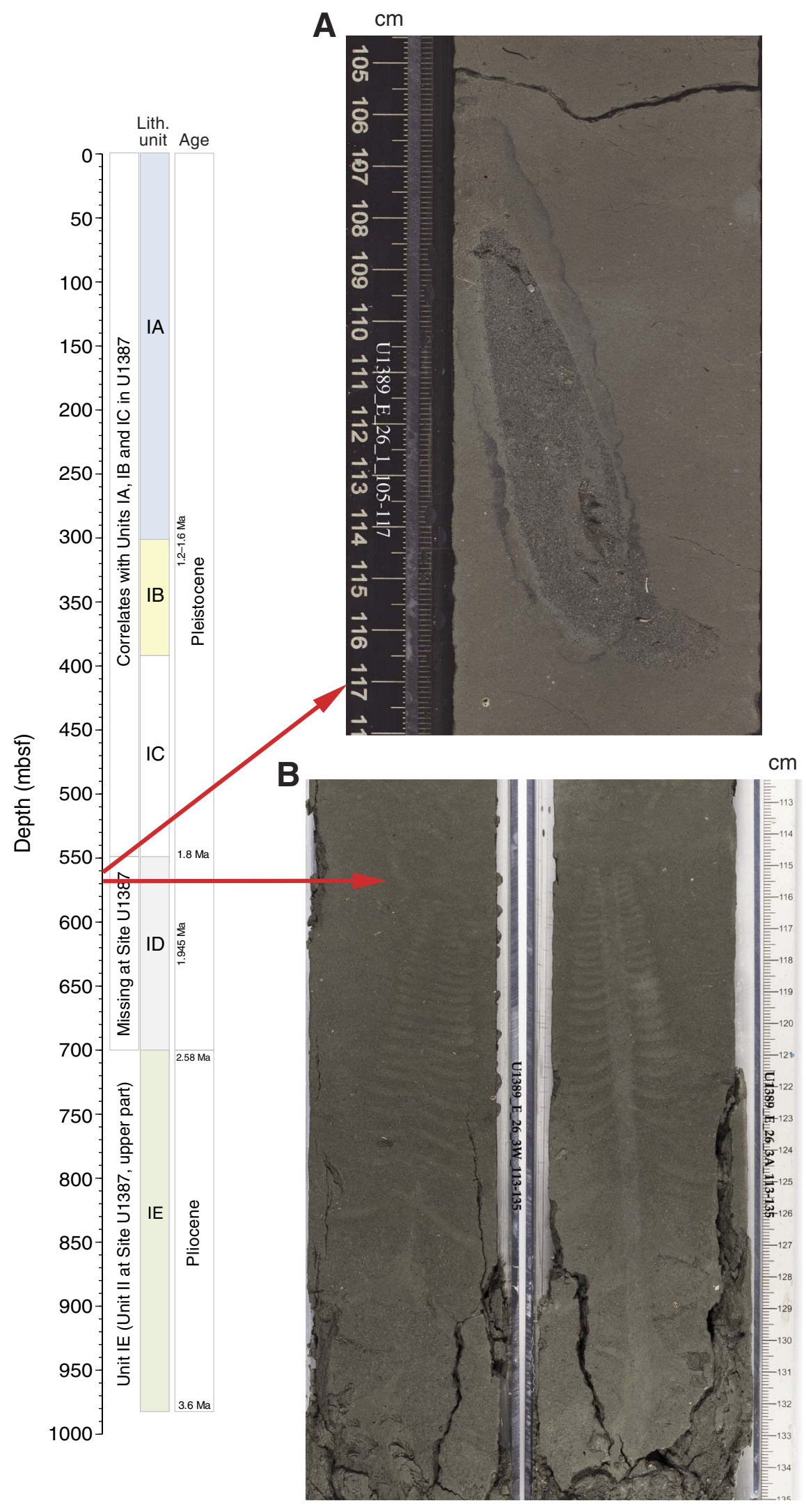


Figure F19. Core image of a large burrow (interval 339-U1389E-57R-1, 124-151 cm).

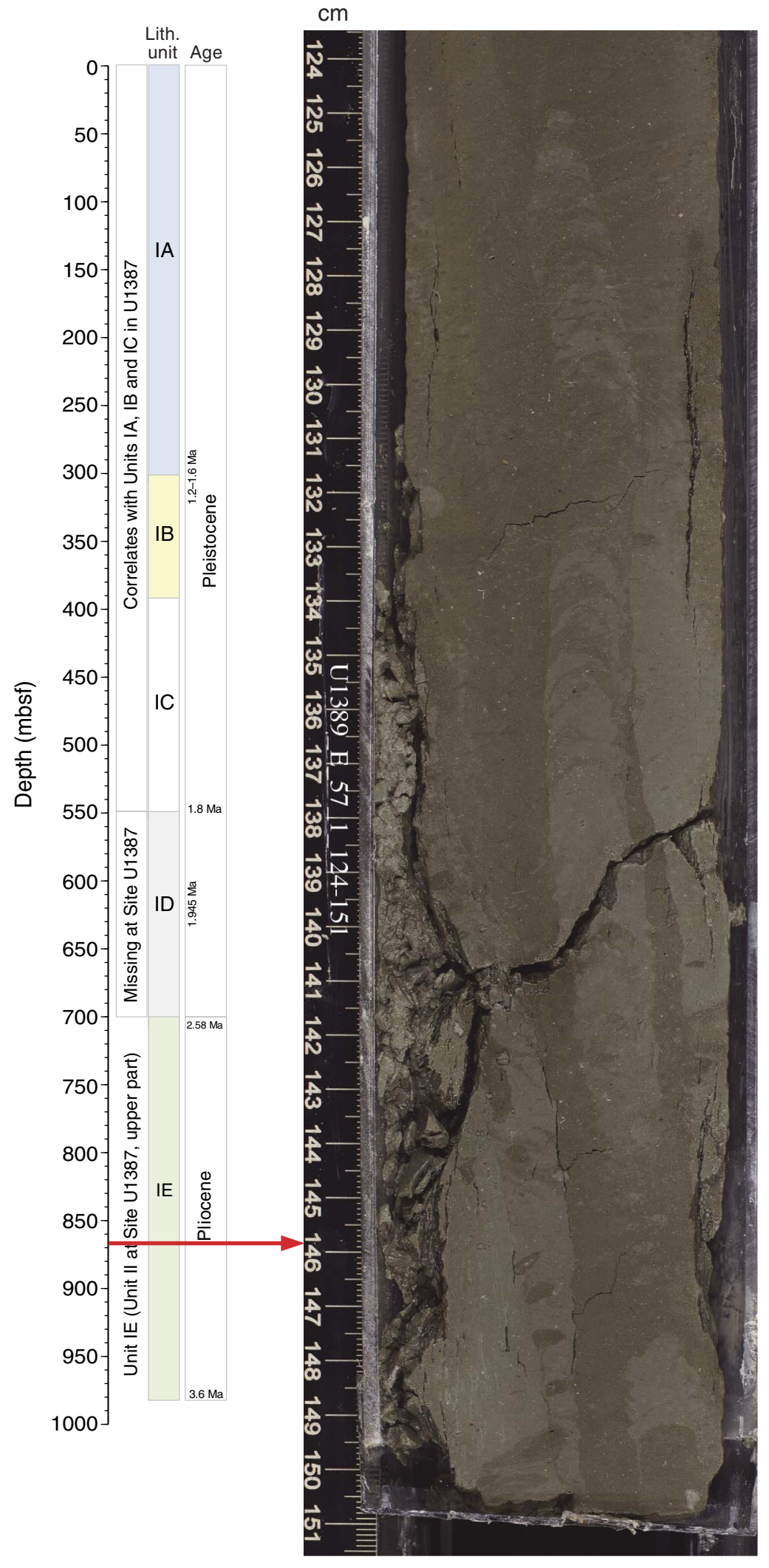


Figure F20. Core image of heavily bioturbated calcareous mud with distinct Zoophycos (interval 339-U1389E58R-3, 26-56 cm).

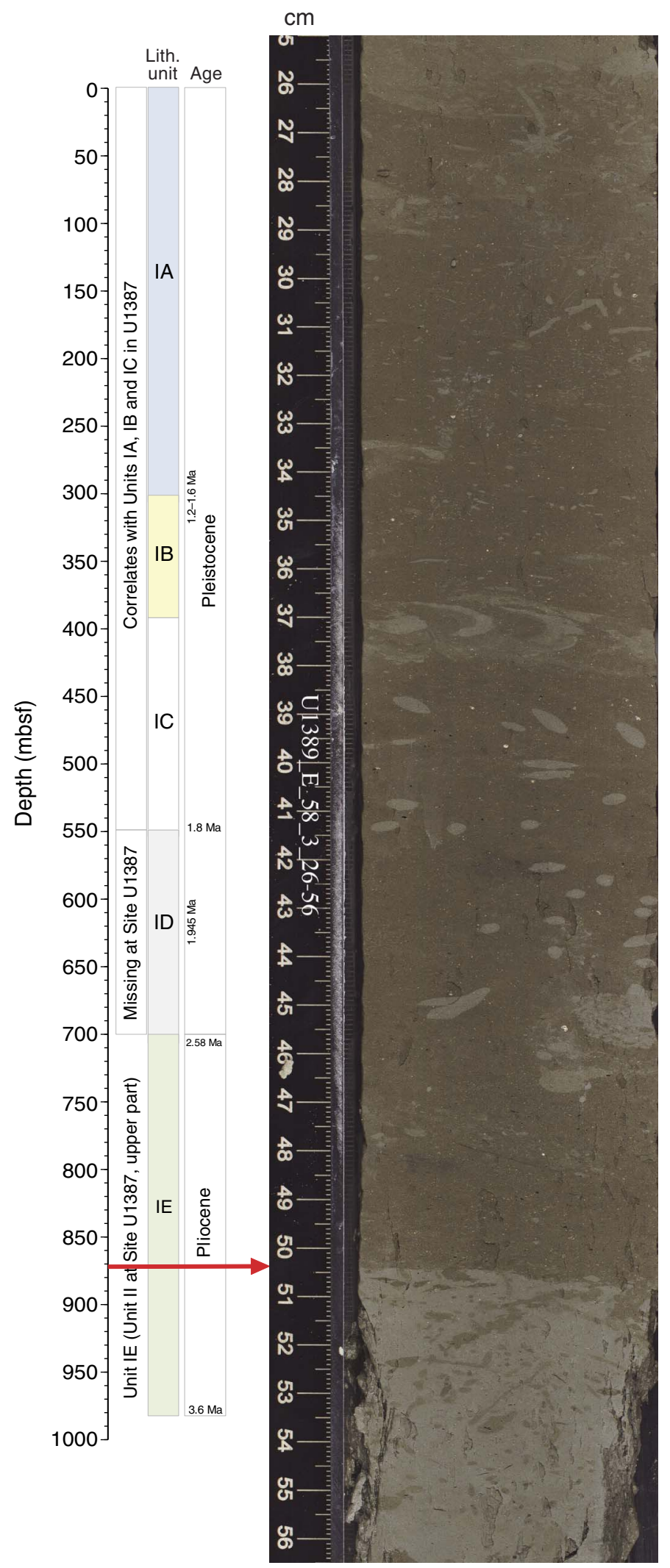


Figure F21. Biostratigraphic events vs. depth, Site U1389. Events are plotted at their mean depth (Table T7). For Hole U1389E, circles are calcareous nannofossil datums, triangles are planktonic foraminifer events, and gray squares are ages for the Olduvai Subchron and Gauss/Matuyama boundary (see "Paleomagnetism").

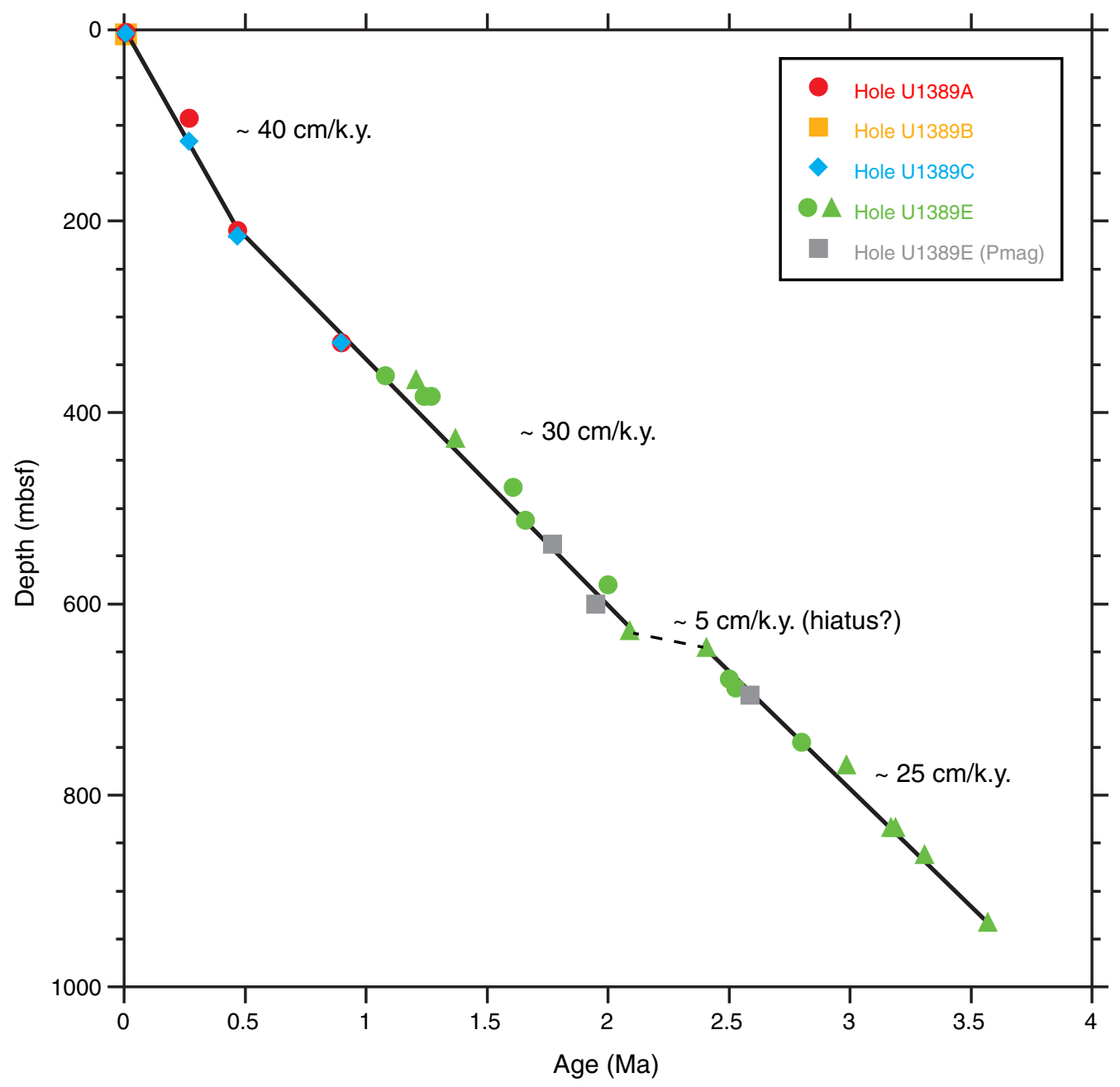

Pleistocene

Pliocene 
Figure F22. Preliminary pollen results from the analysis of 16 samples at Site U1389. Mediterranean forest is mainly deciduous and evergreen Quercus and Olea; semidesert is Artemisia, Chenopodiaceae, and Ephedra; and grassland is mainly Poaceae and Taraxacum-type. TPS = total pollen and spores. Preservation: $\mathrm{G}=$ good, $\mathrm{M}=$ moderate, $\mathrm{P}=$ poor.

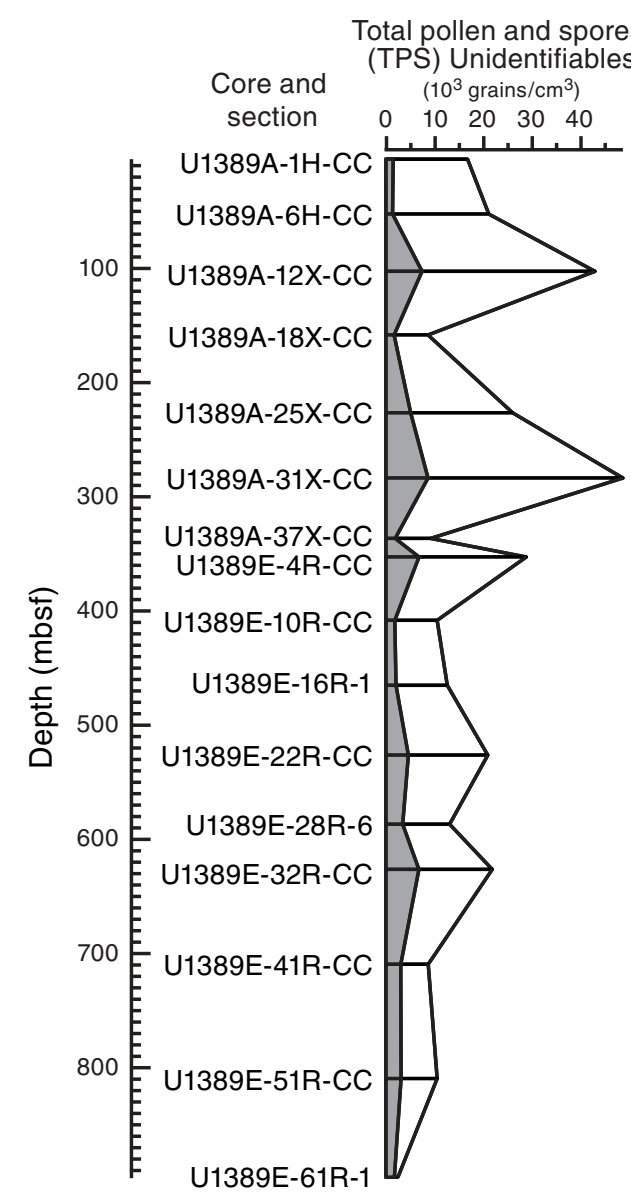

Mediterranean Porest Semidesert Grassland Unidentifiables/ TPS Corroded conifers/TPS type/TPS grains $\left./ \mathrm{cm}^{3}\right) \quad\left(10^{3}\right.$ grains $\left./ \mathrm{cm}^{3}\right) \quad\left(10^{3}\right.$ grains $\left./ \mathrm{cm}^{3}\right) \quad\left(10^{3}\right.$ grains $\left./ \mathrm{cm}^{3}\right)$ $\left(10^{3}\right.$ grains $\left./ \mathrm{cm}^{3}\right)$ \begin{tabular}{lll}
0 & 0.4 & $\left(10^{3}\right.$ grains $\left./ \mathrm{cm}^{3}\right)$ \\
\hline & 0 & $\left(10^{2}\right)$
\end{tabular} $\left(0^{3}\right.$ grains $\left./ \mathrm{cm}^{3}\right)$
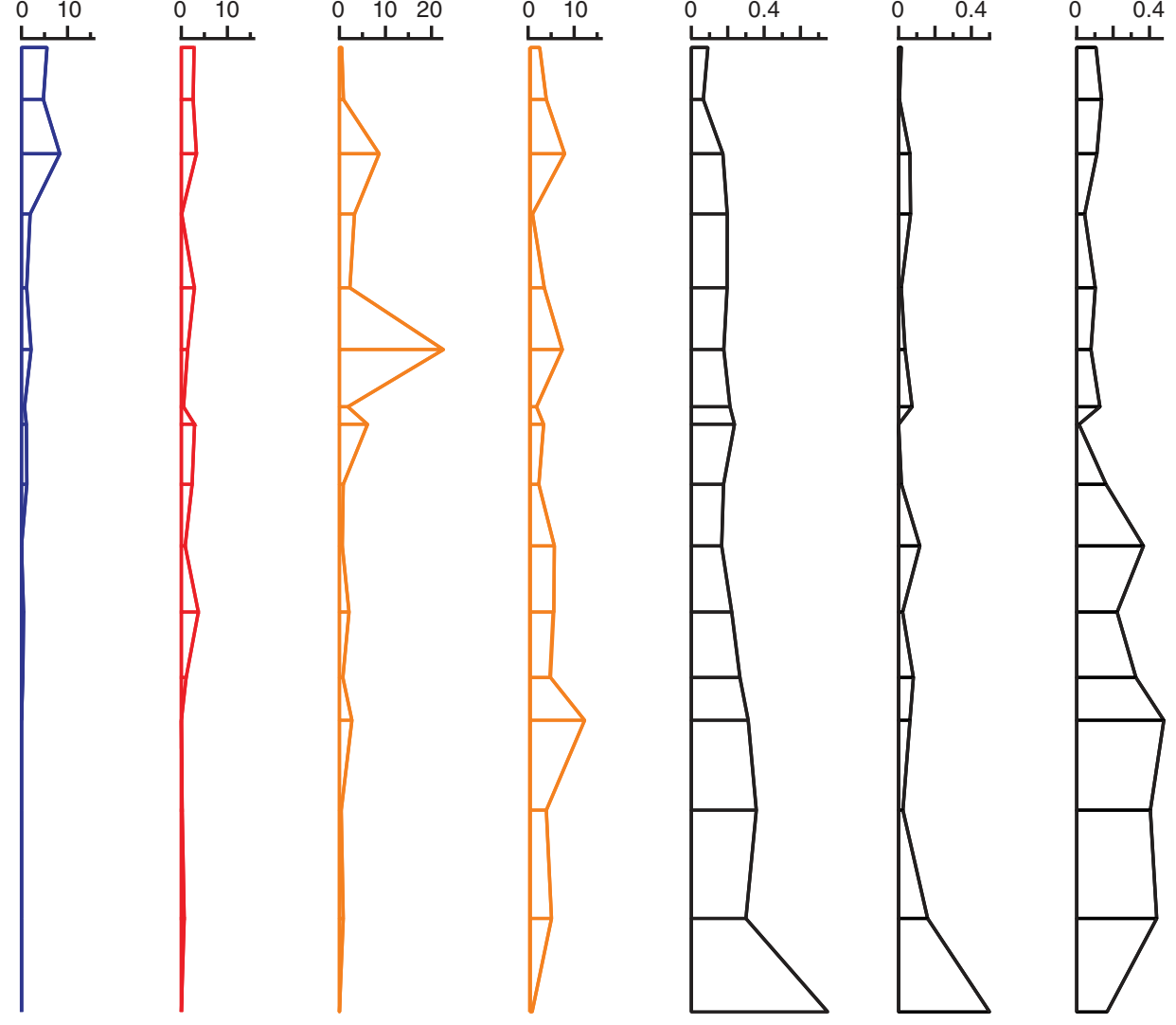

Preservation

Age (Ma)

$0.01 \quad G$

$0.27 \quad G$ 
Figure F23. Paleomagnetism after $20 \mathrm{mT}$ AF demagnetization, Site U1389. Blue triangles = discrete sample locations. Yellow circles $=$ component inclinations of discrete samples with maximum angular deviation less than $\sim 15^{\circ}$. In the Chron columns, black $=$ normal polarity, white $=$ reversed polarity, and gray $=$ zones or polarity boundaries without a clear magnetostratigraphic interpretation. In Inclination columns, blue dashed lines = expected GAD inclinations at the site latitude during reversed (left) and normal (right) polarities. In Susceptibility columns, gray lines indicate SHMSL susceptibility plus $25 \times 10^{-5}$ volume SI to better show the comparison with WRMSL susceptibility (black lines). (Figure shown on next five pages.) 
Figure F23 (continued). A. Hole U1389A. (Caption shown on previous page.) (Continued on next page.)

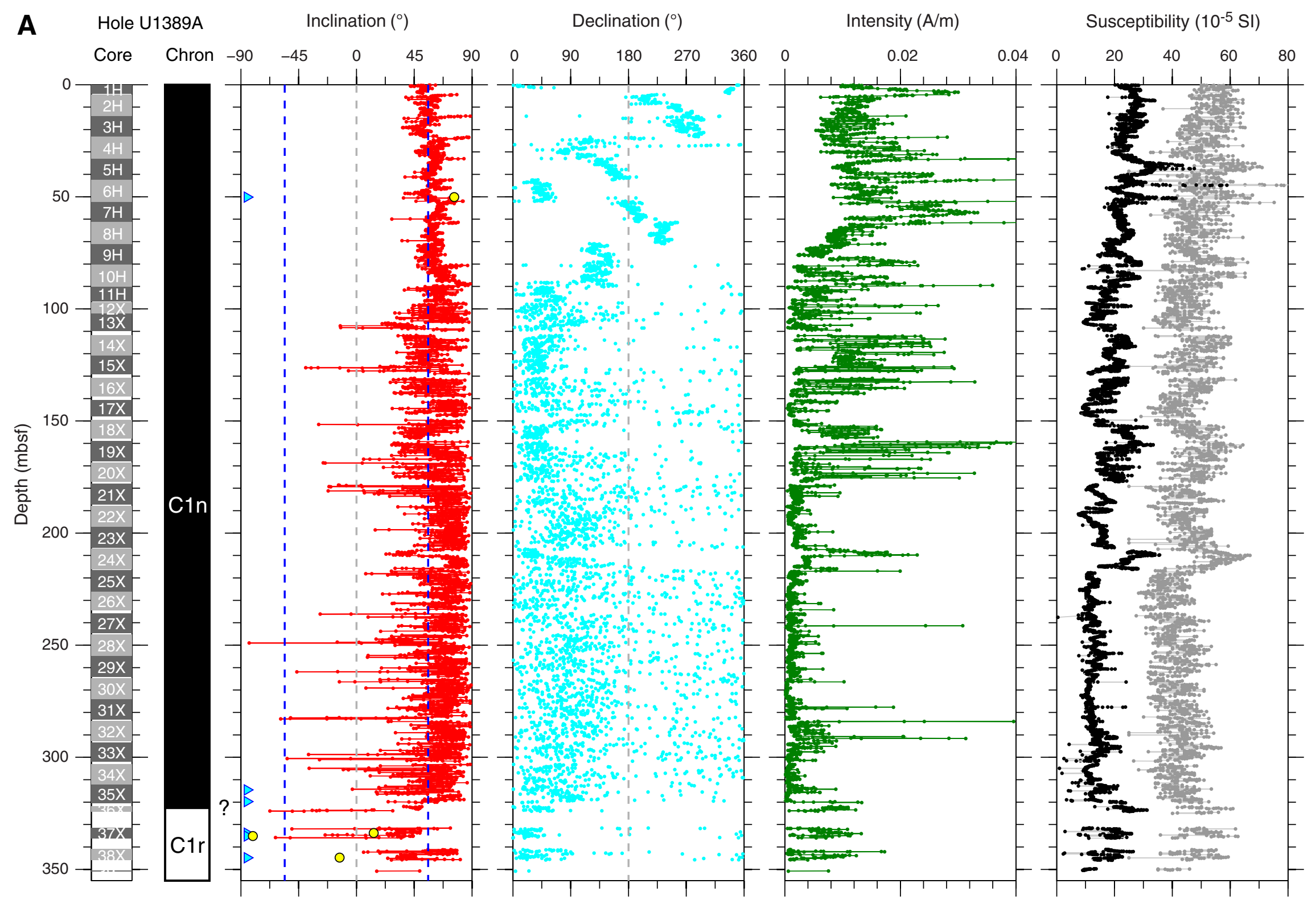




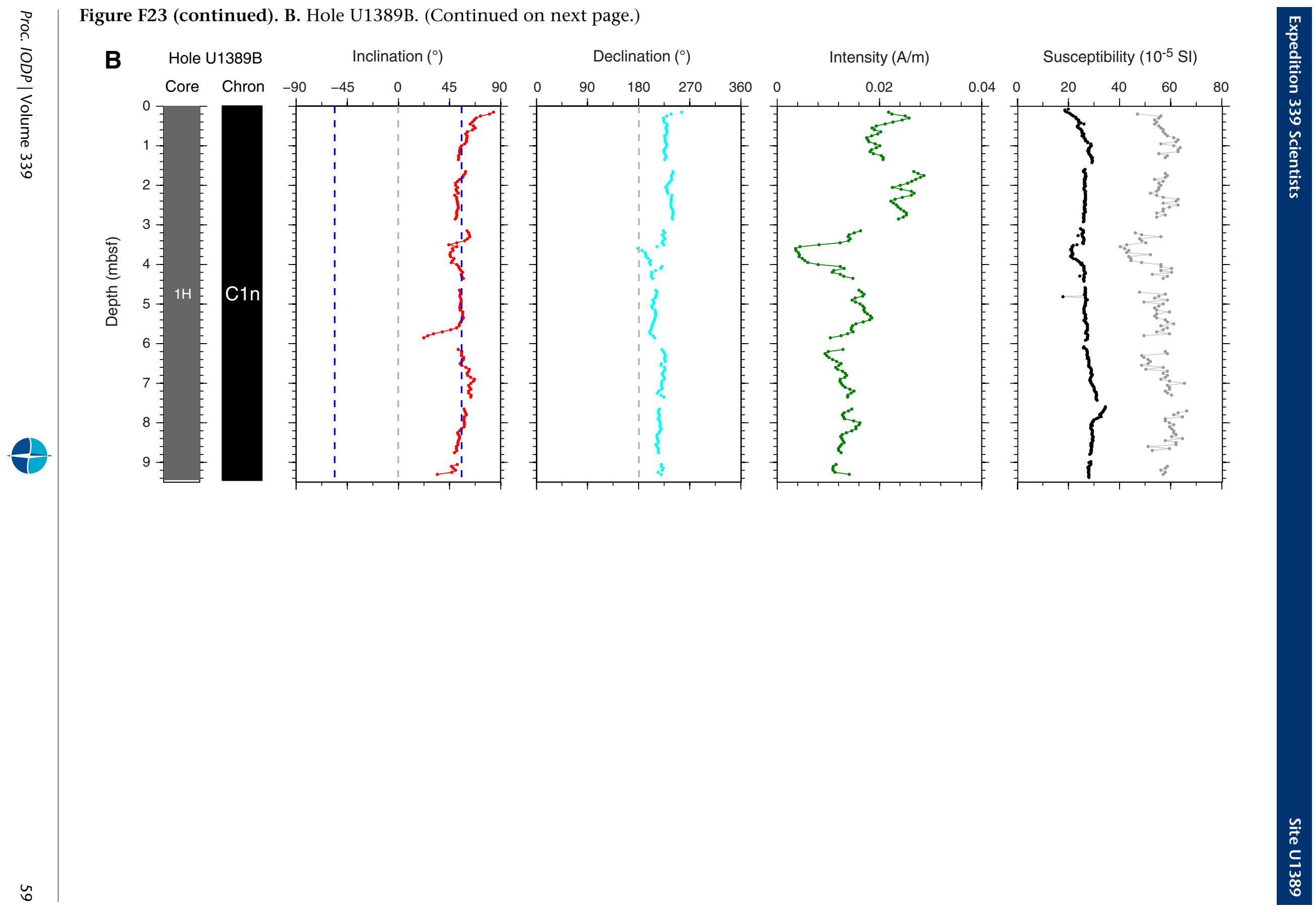


Figure F23 (continued). C. Hole U1389C. (Continued on next page.)
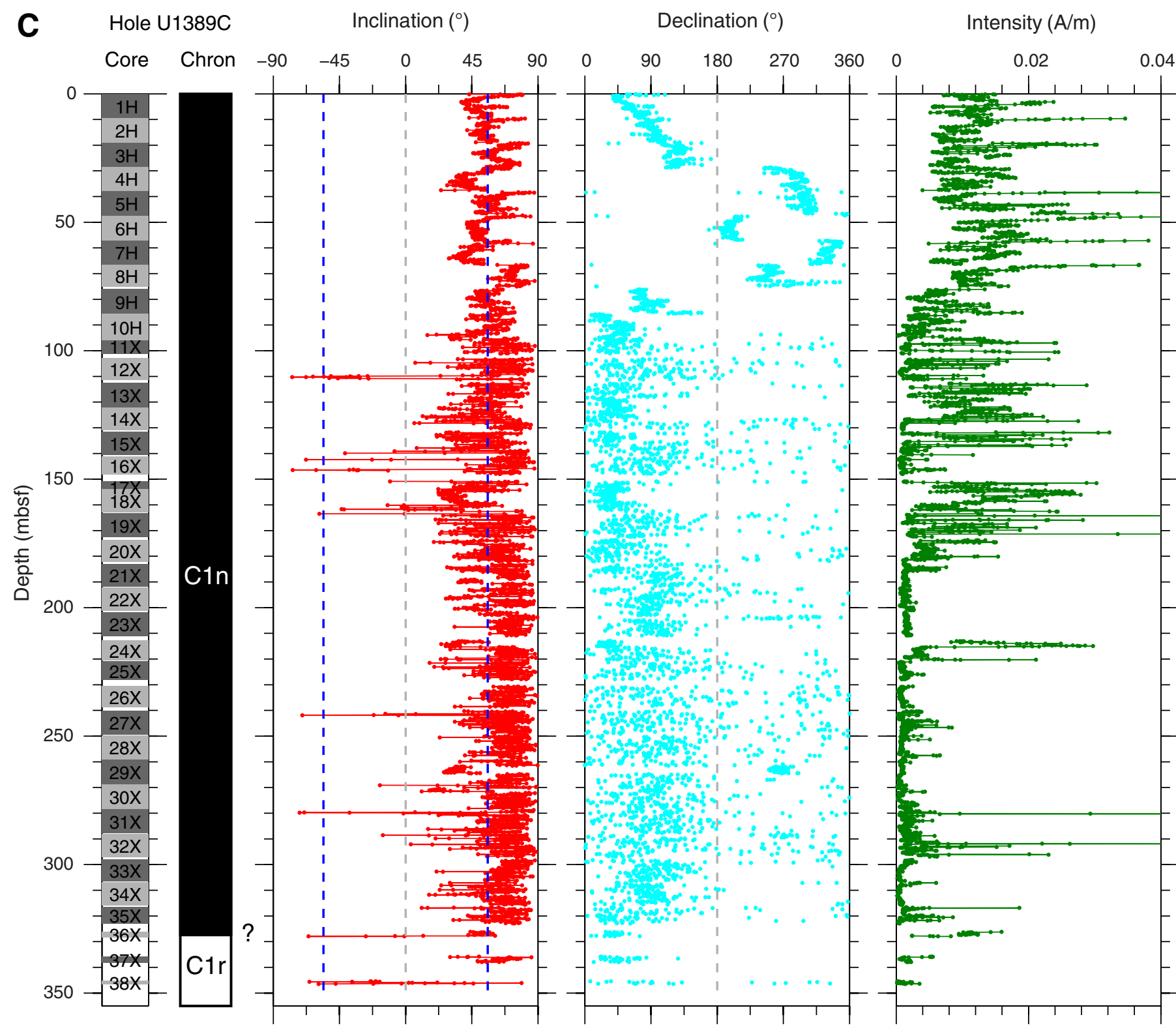

Susceptibility $\left(10^{-5} \mathrm{SI}\right)$

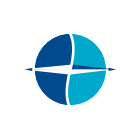


Figure F23 (continued). D. Hole U1389D. (Continued on next page.)

D Hole U1389D Inclination $\left(^{\circ}\right) \quad$ Declination $\left({ }^{\circ}\right)$

Intensity $(\mathrm{A} / \mathrm{m})$

Susceptibility $\left(10^{-5} \mathrm{SI}\right)$

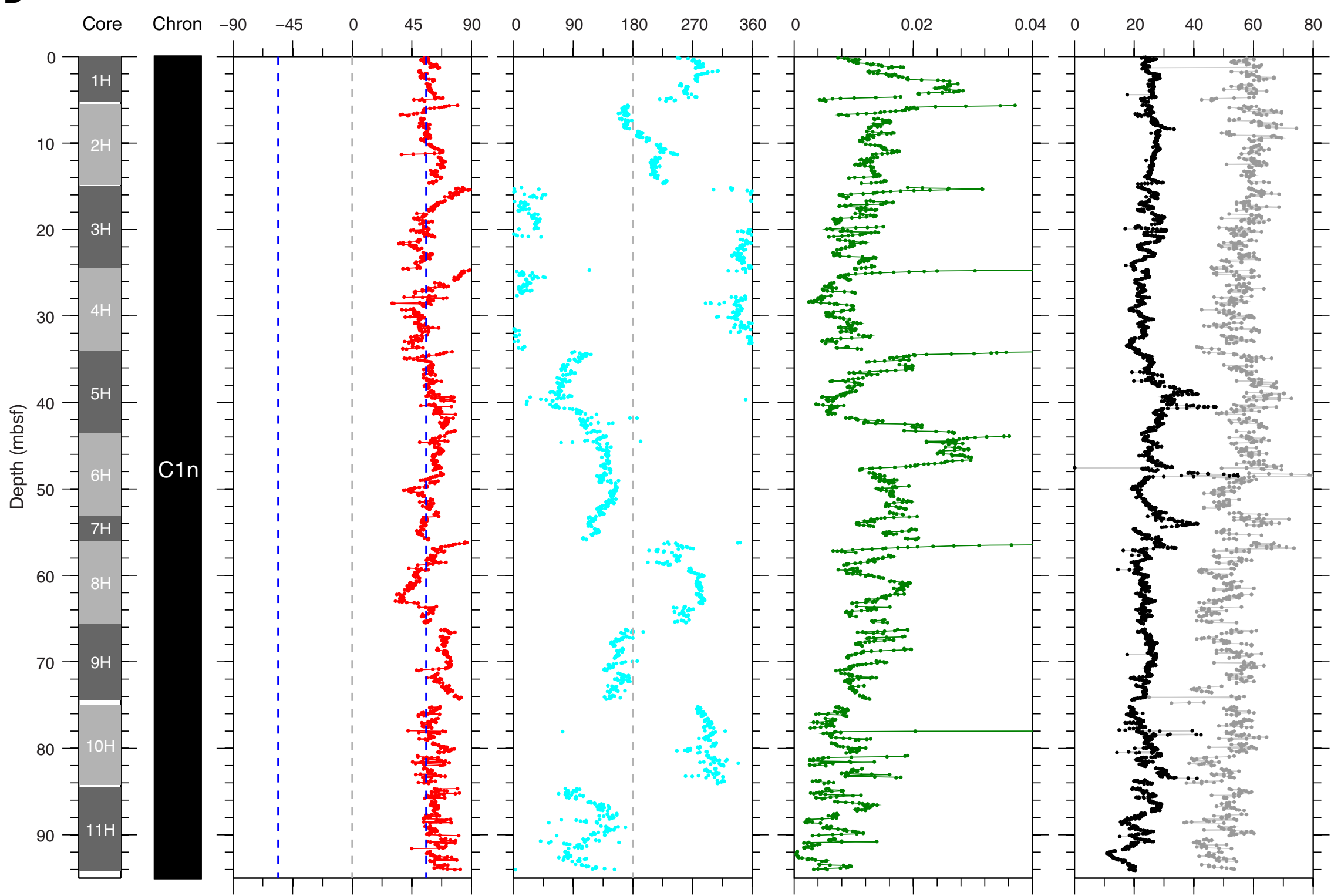


Figure F23 (continued). E. Hole U1389E.

E Hole U1389E

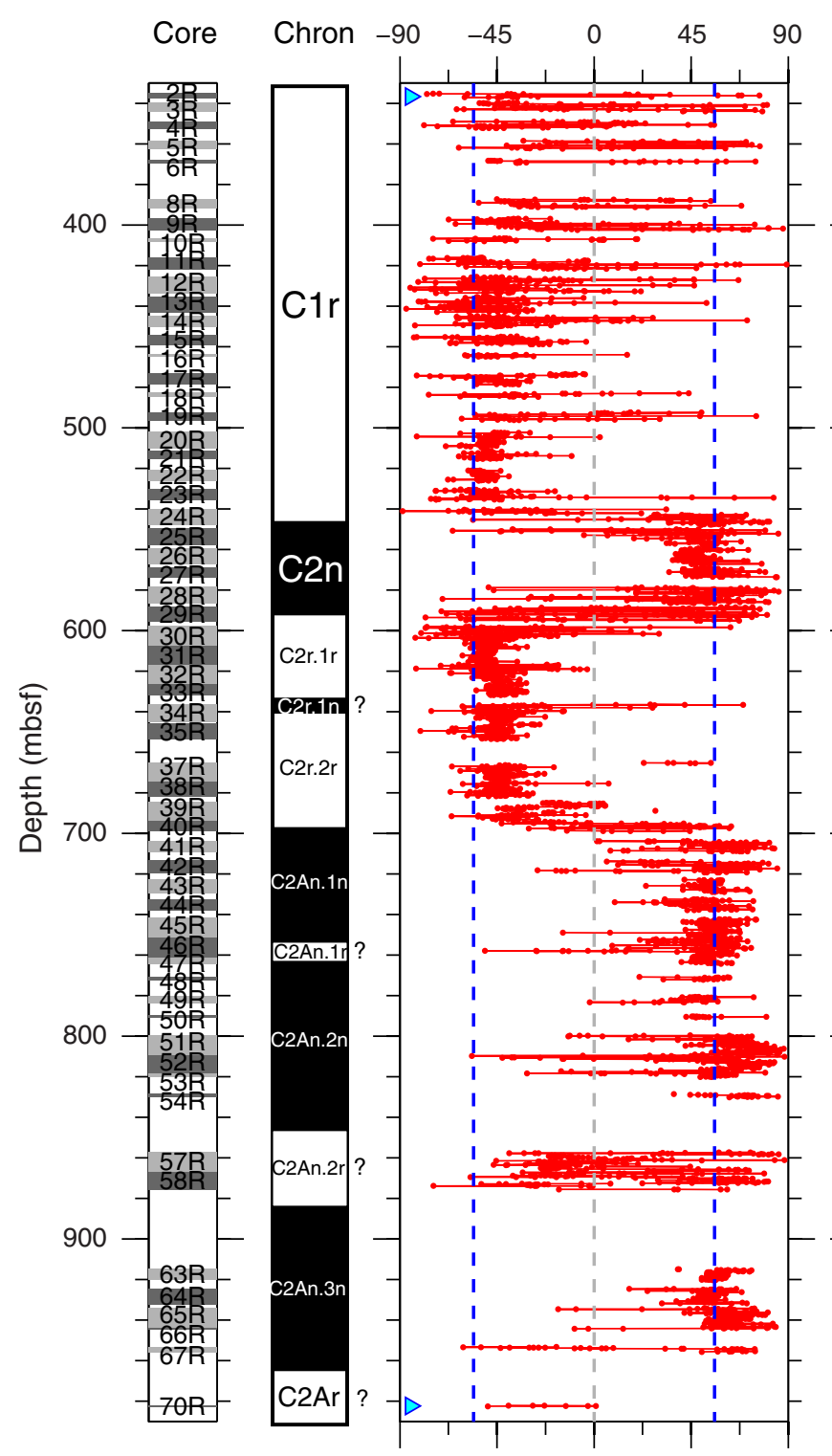

Declination $\left({ }^{\circ}\right)$

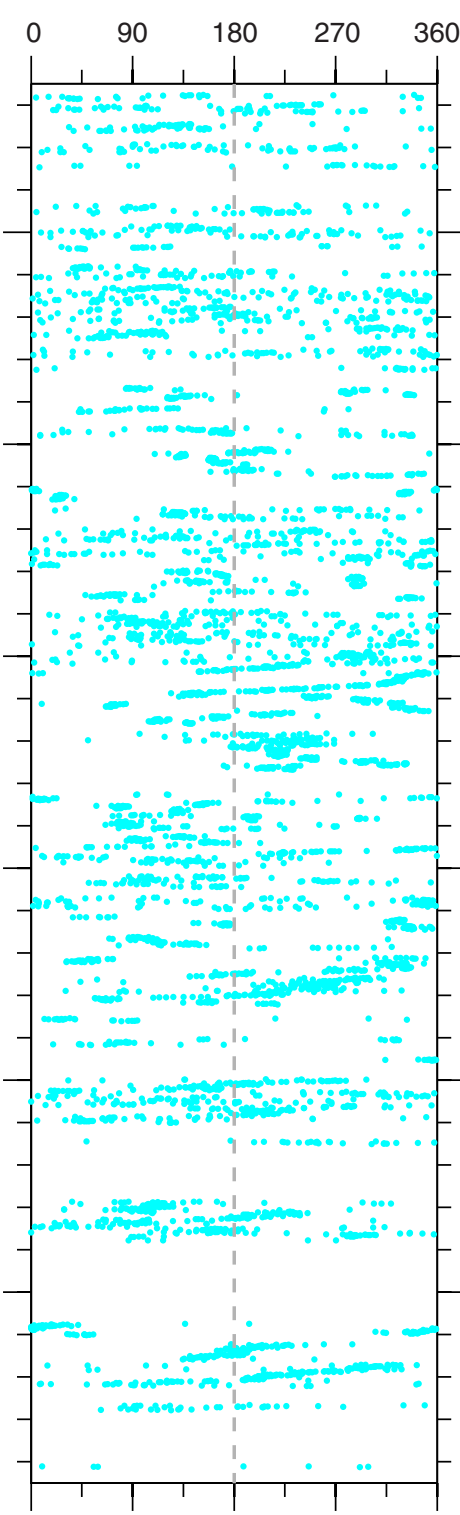

Intensity $(\mathrm{A} / \mathrm{m})$

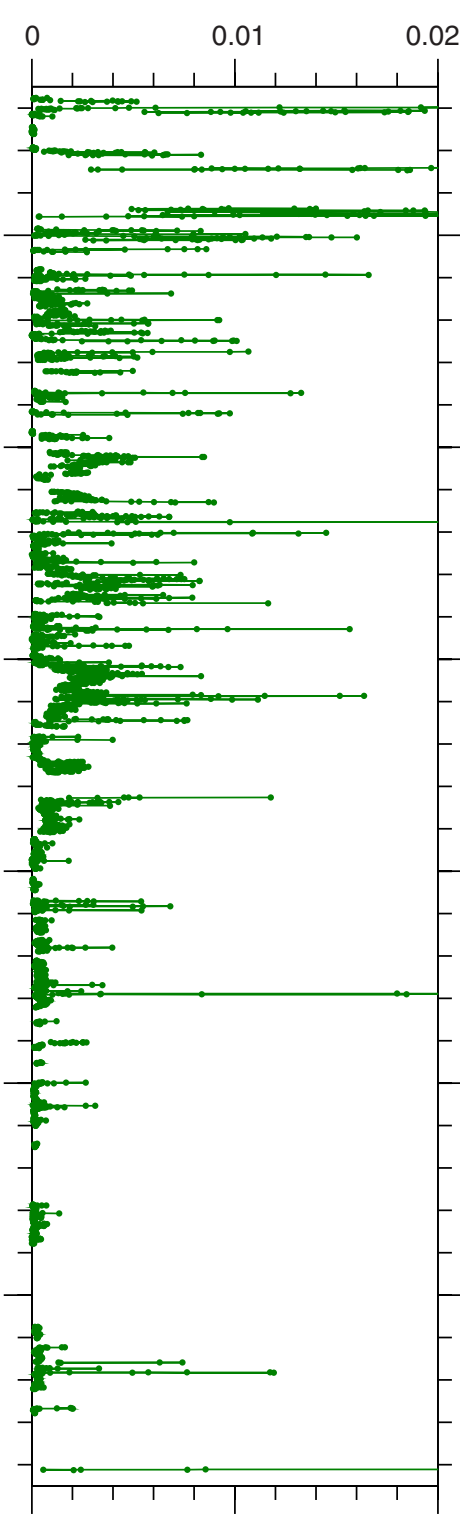

Susceptibility $\left(10^{-5} \mathrm{SI}\right)$

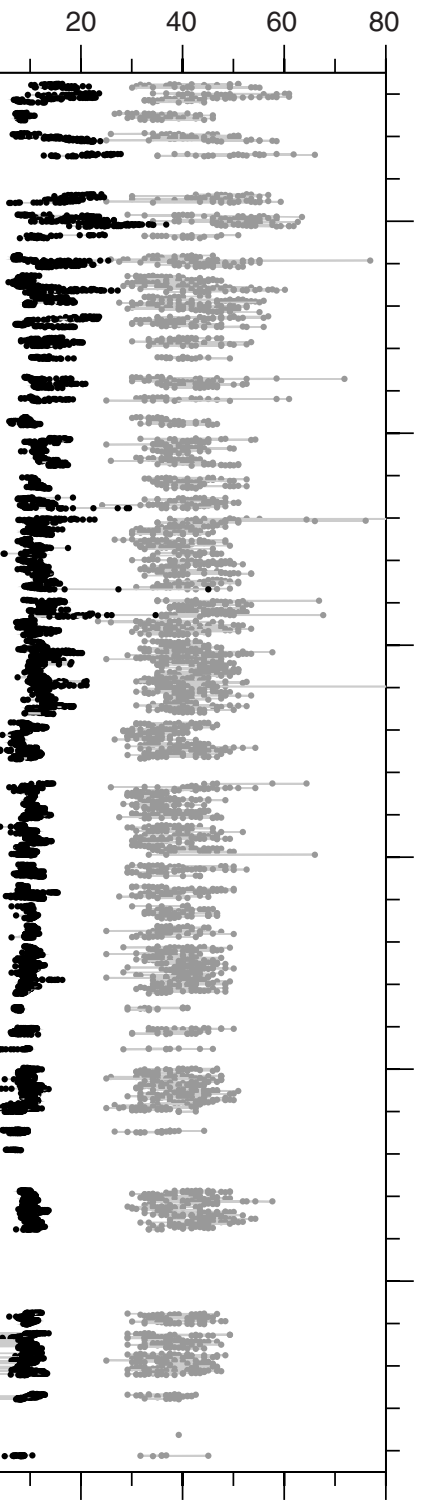


Figure F24. AF demagnetization results for four discrete samples, Site U1389. For each sample, the right plot shows the vector endpoints of paleomagnetic directions measured after each demagnetization treatment on an orthogonal projection (Zijderveld) plot. Squares $=$ horizontal projections, circles $=$ vertical projections. The left plot shows the intensity variation with progressive demagnetization. Orthogonal projection plots illustrate the removal of a steep drilling overprint by $\sim 15-20 \mathrm{mT}$ peak field AF demagnetization and a significant amount of ARM acquisition during high-peak field (greater than $~ 55 \mathrm{mT}$ ) AF demagnetization, with the remaining magnetization providing a well-resolved characteristic remanent magnetization.
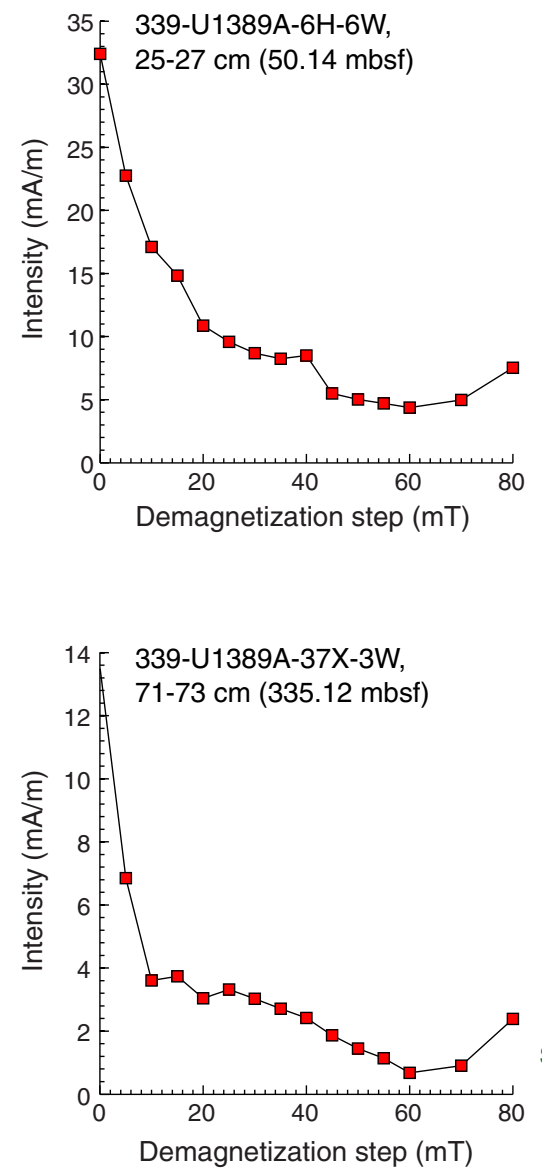
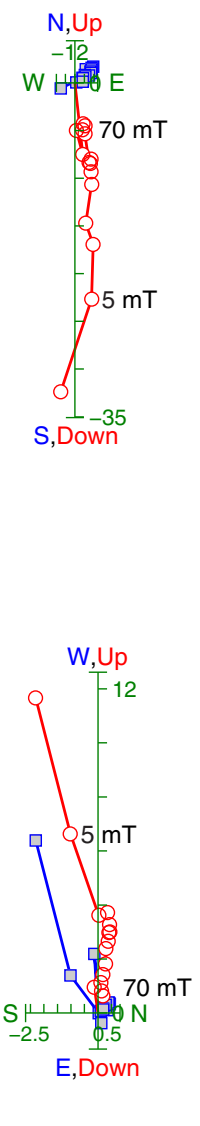
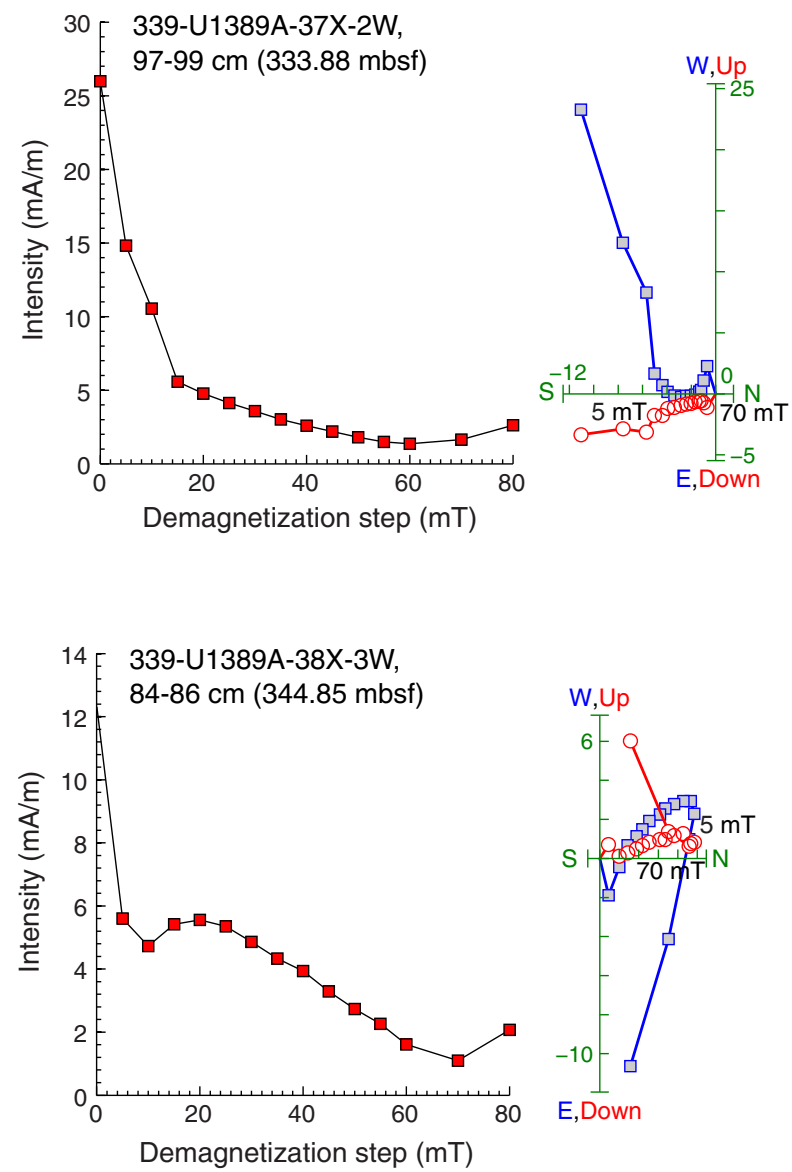
Figure F25. Plots of $P$-wave velocity (PWV) measured on the Whole-Round Multisensor Logger (WRMSL; green lines) and on the Section Half Measurement Gantry (discrete samples) set to automatic (solid circles) and manual (open circles) mode, wet bulk density (red diamonds) on discrete samples, and gamma ray attenuation density and magnetic susceptibility (MS) measured on the WRMSL (black lines) and on split cores (green points). Note that records were cleaned for outliers and bad data at sections ends. PP $=$ physical properties. A. Hole U1389A. (Continued on next page.)

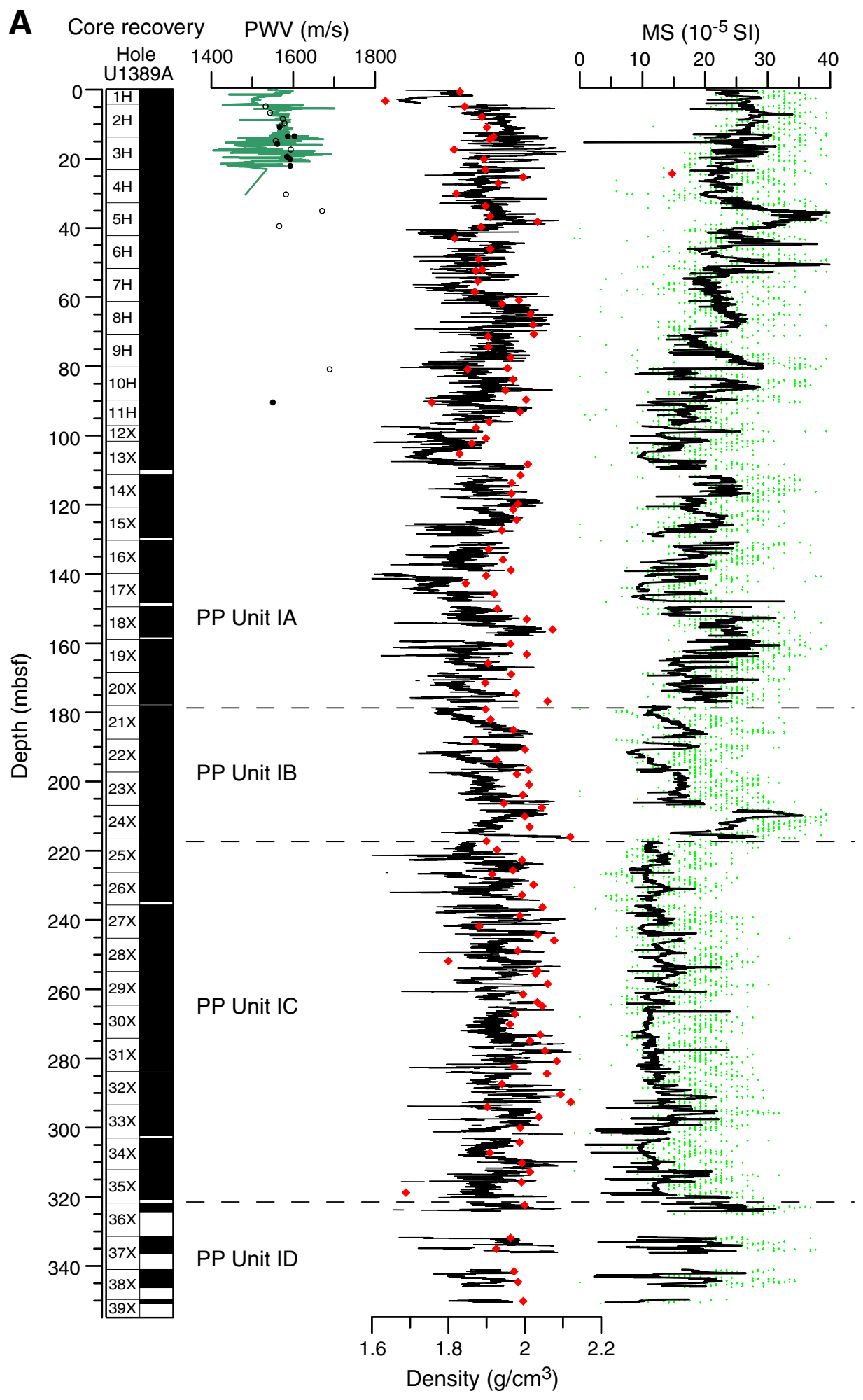


Figure F25 (continued). B. Hole U1389E.

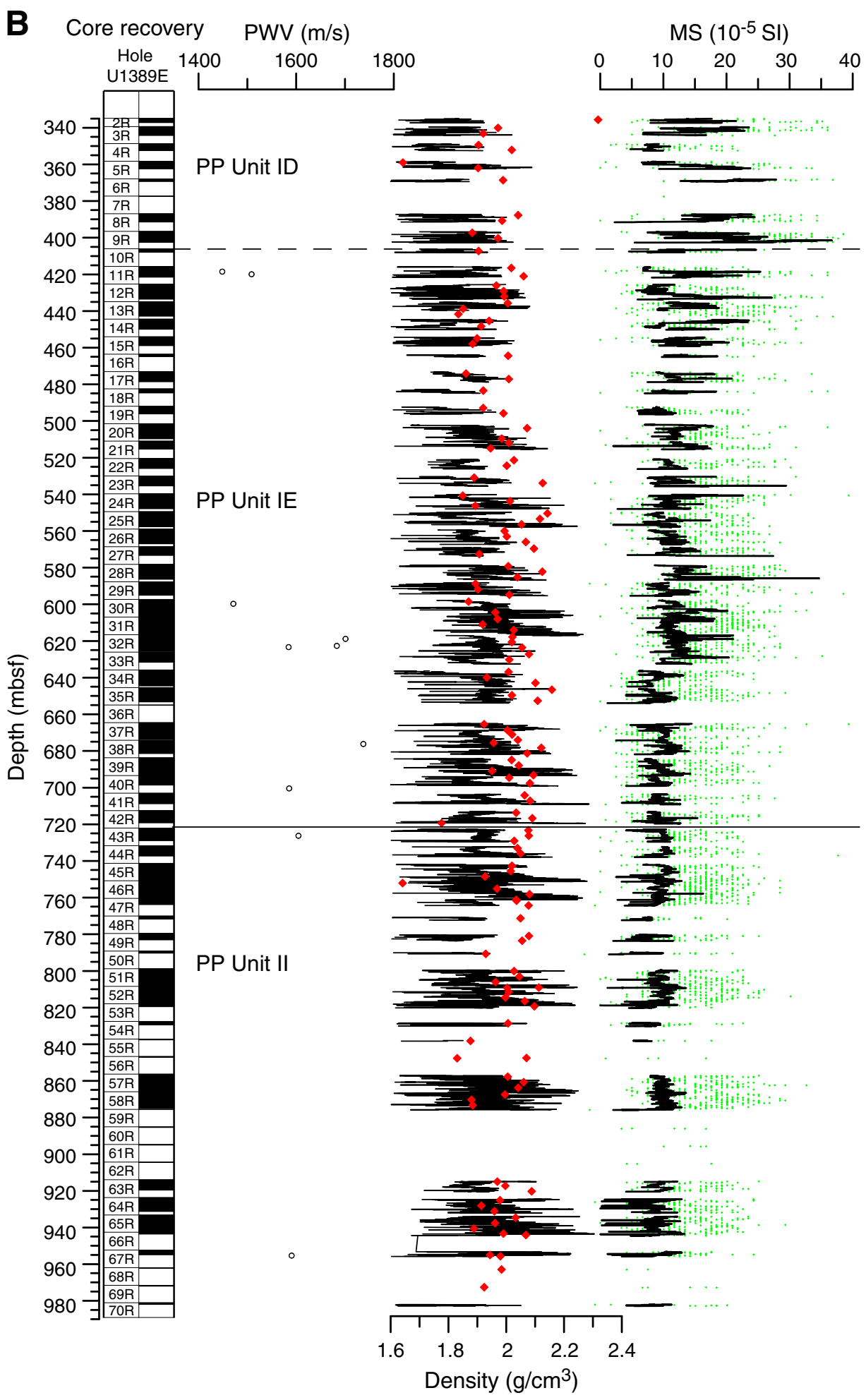


Figure F26. Plots of color reflectance $\left(\mathrm{L}^{*}, \mathrm{a}^{*}\right)$ and natural gamma ray (NGR) measurements. Note that data were cleaned for outliers and bad data at section ends. Reflectance data were smoothed with a 10-point running mean. $\mathrm{PP}=$ physical properties. A. Hole U1389A. (Continued on next page.)

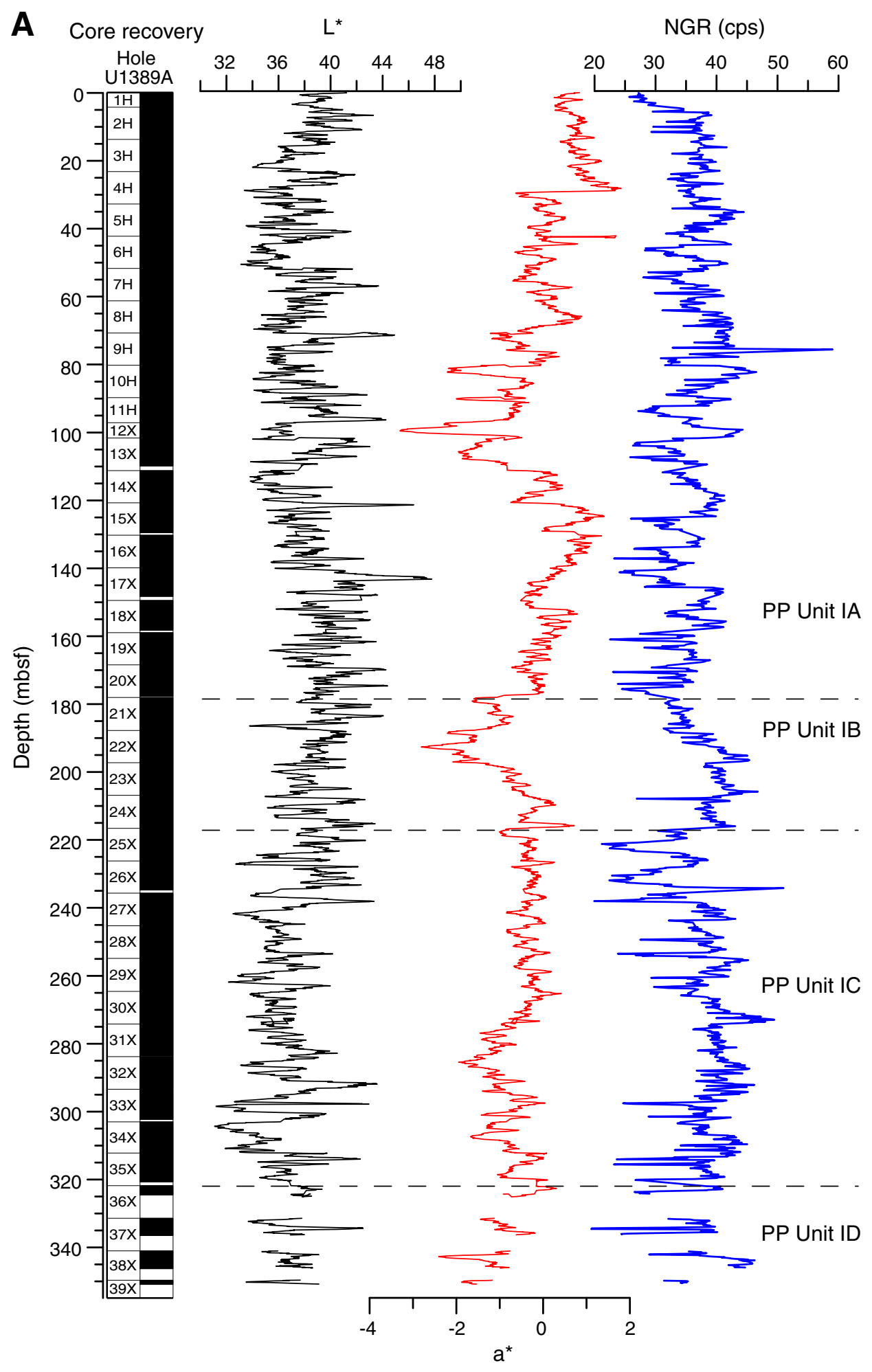


Figure F26 (continued). B. Hole U1389E.

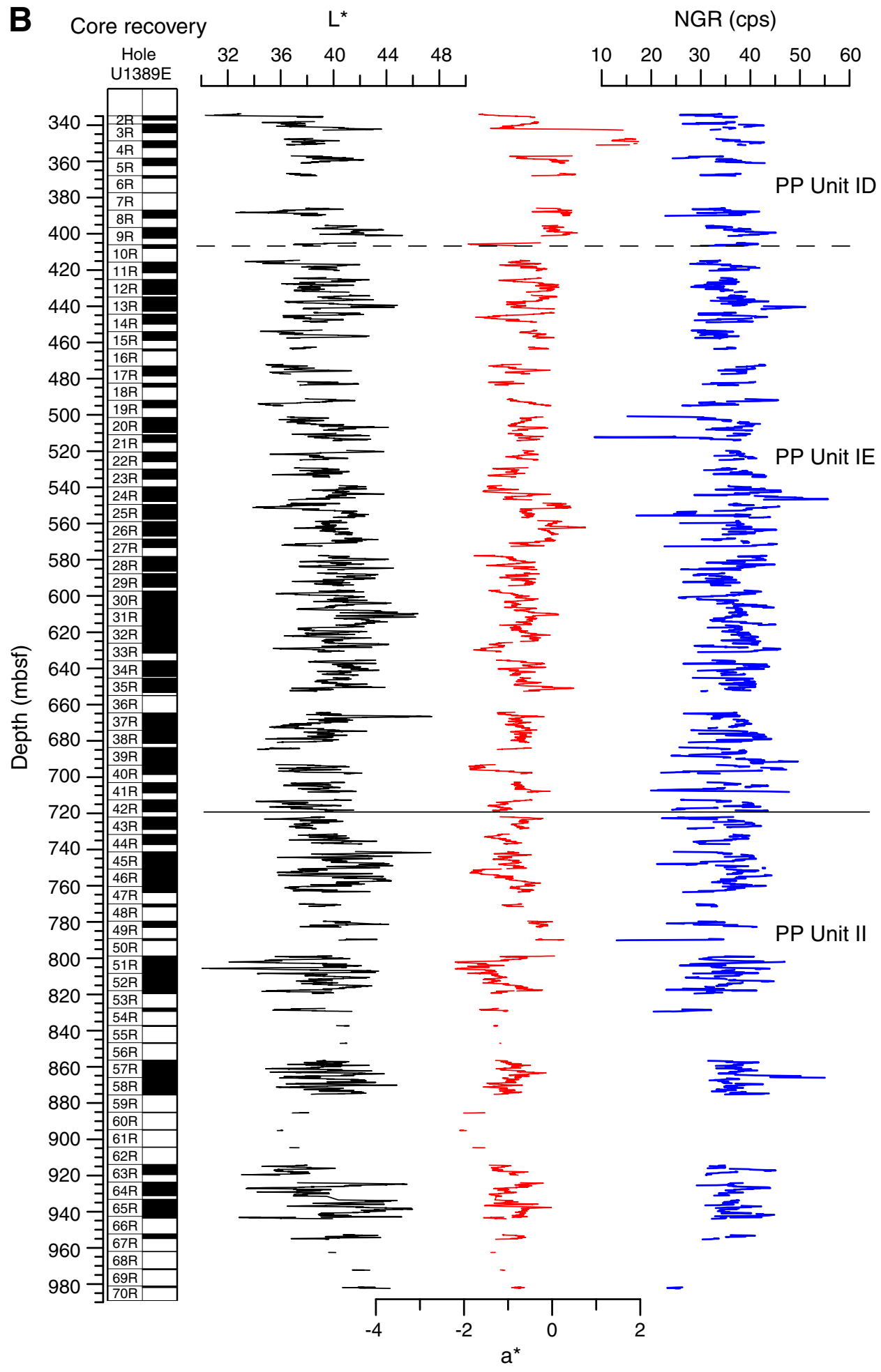


Figure F27. Plots of downhole distribution of discrete measurements of grain density, moisture content, and porosity. PP = physical properties. A. Hole U1389A. (Continued on next page.)

A Core recovery Grain density $\left(\mathrm{g} / \mathrm{cm}^{3}\right)$

Porosity (\%)

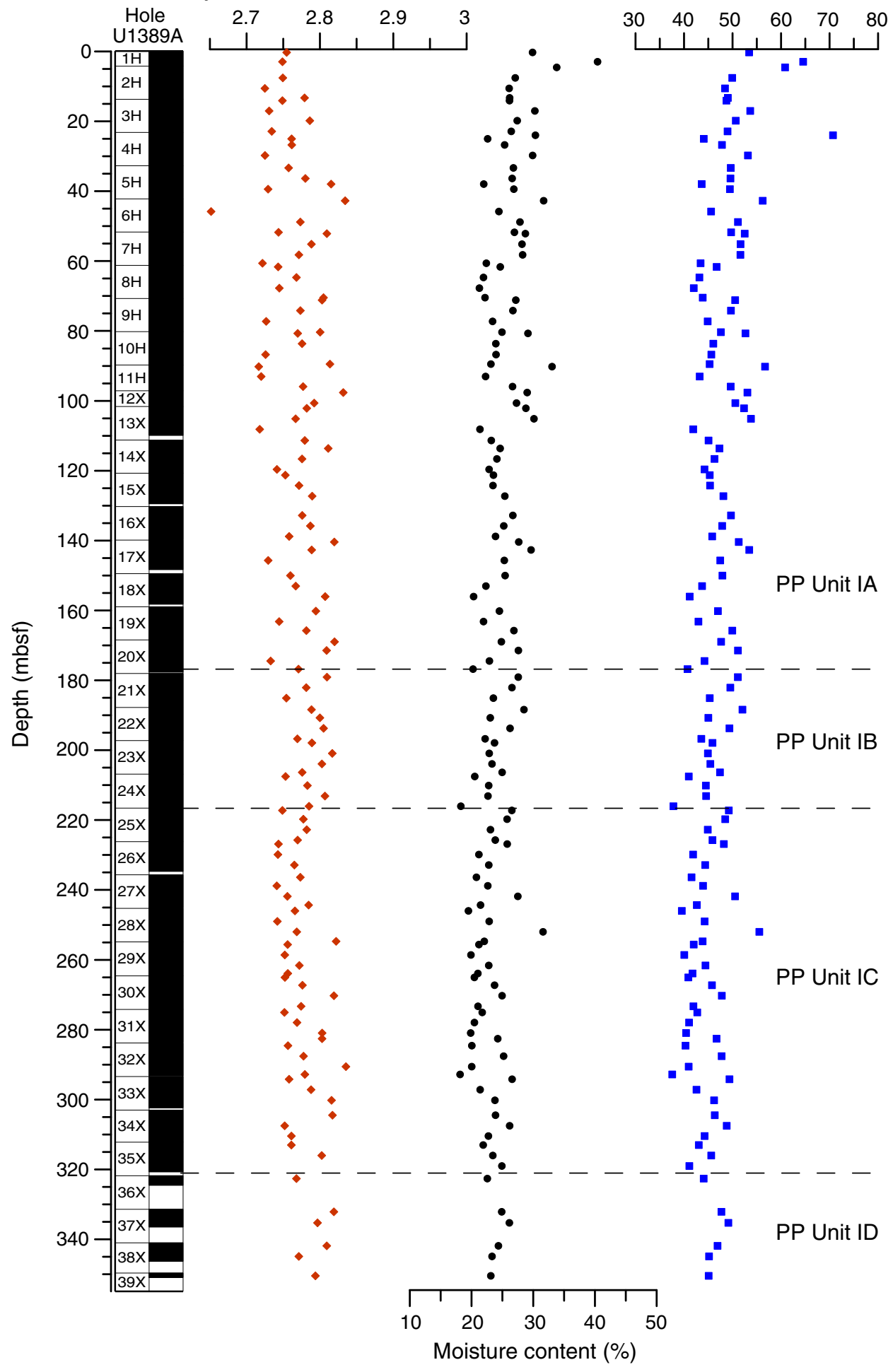


Figure F27 (continued). B. Hole U1389E.

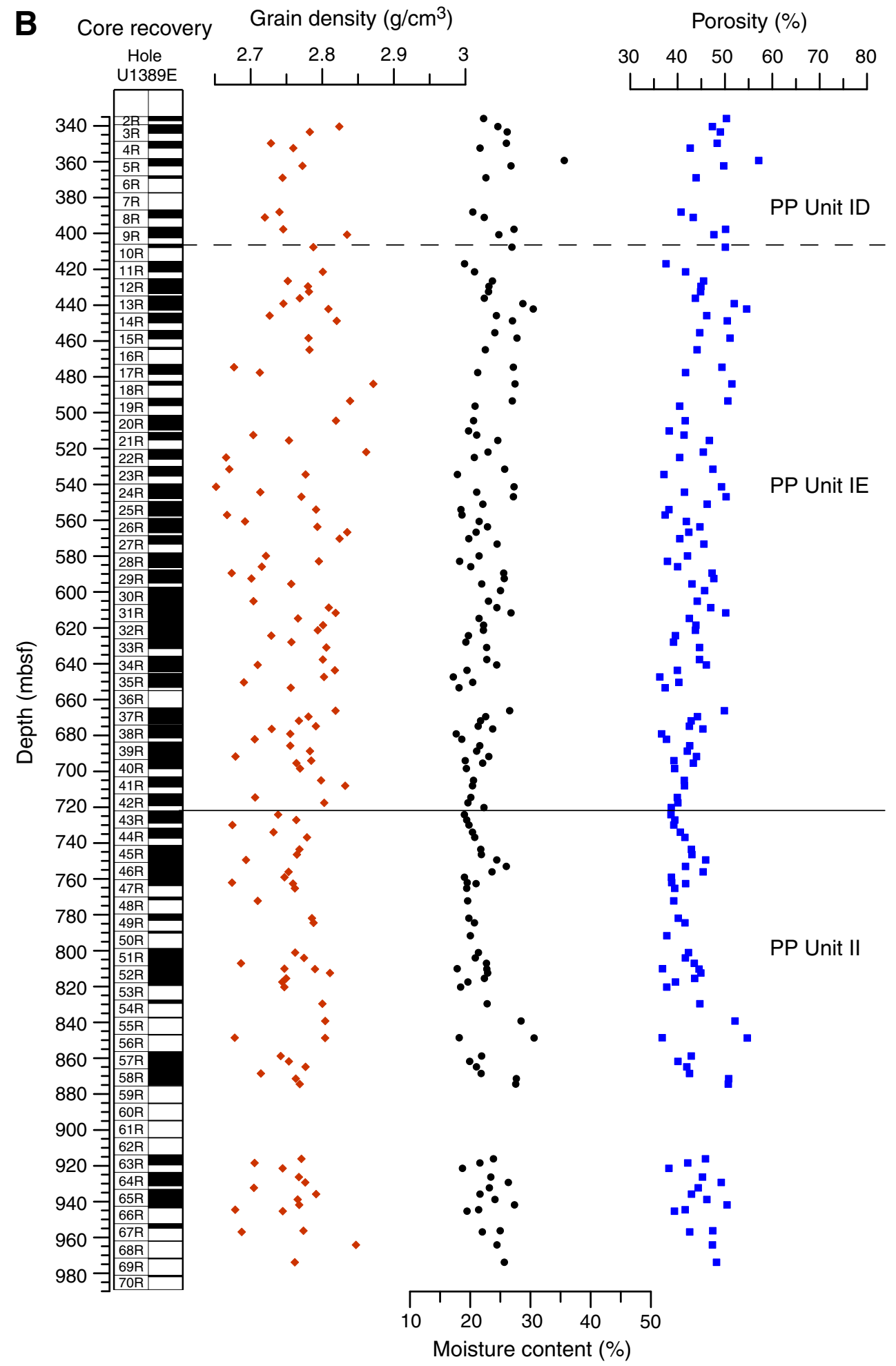


Figure F28. Plot of headspace gas analyses for volatile hydrocarbons, Holes U1389A and U1389E.

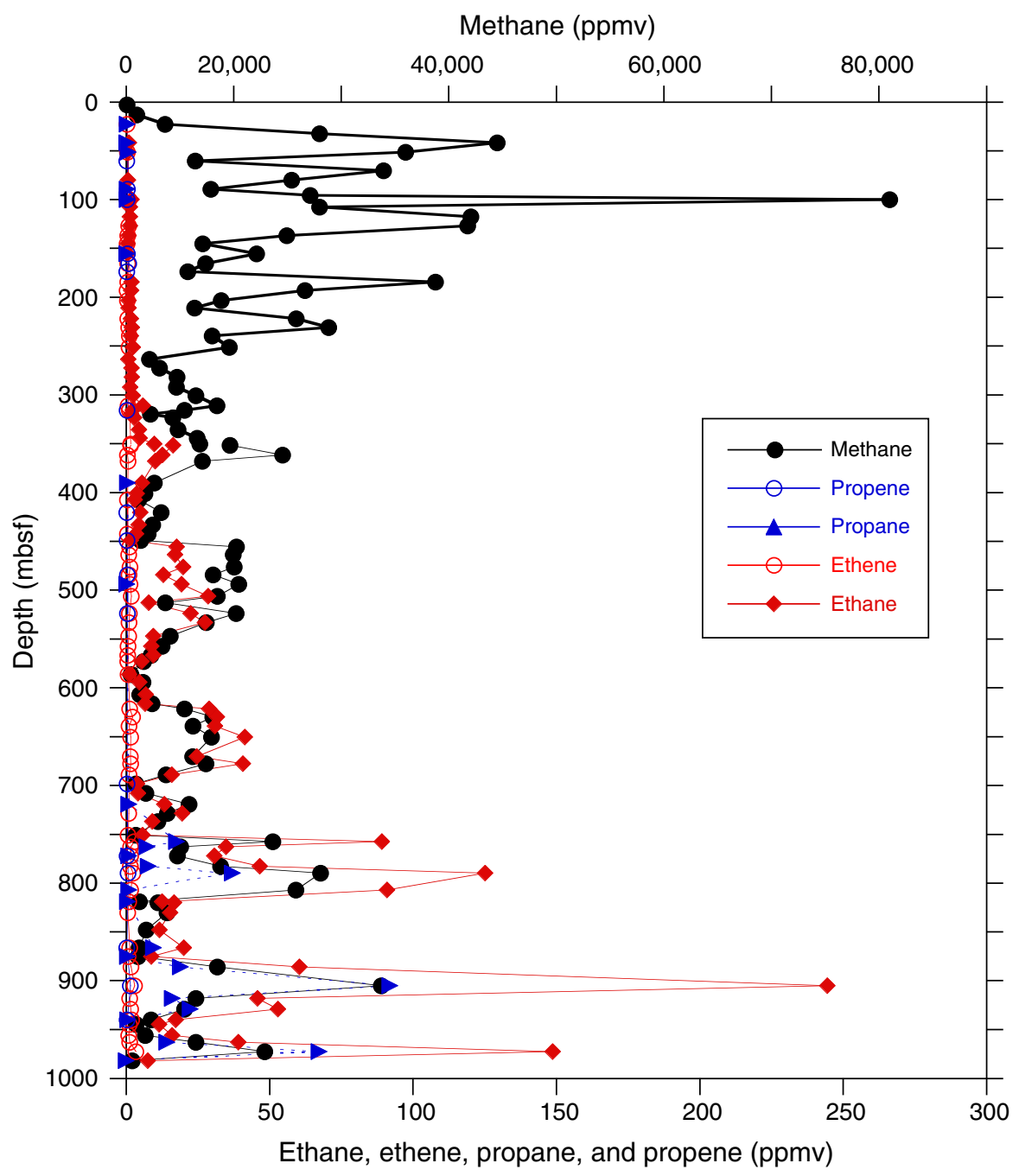


Figure F29. Plot of calcium carbonate, Holes U1389A (solid circles) and U1387E (open circles).

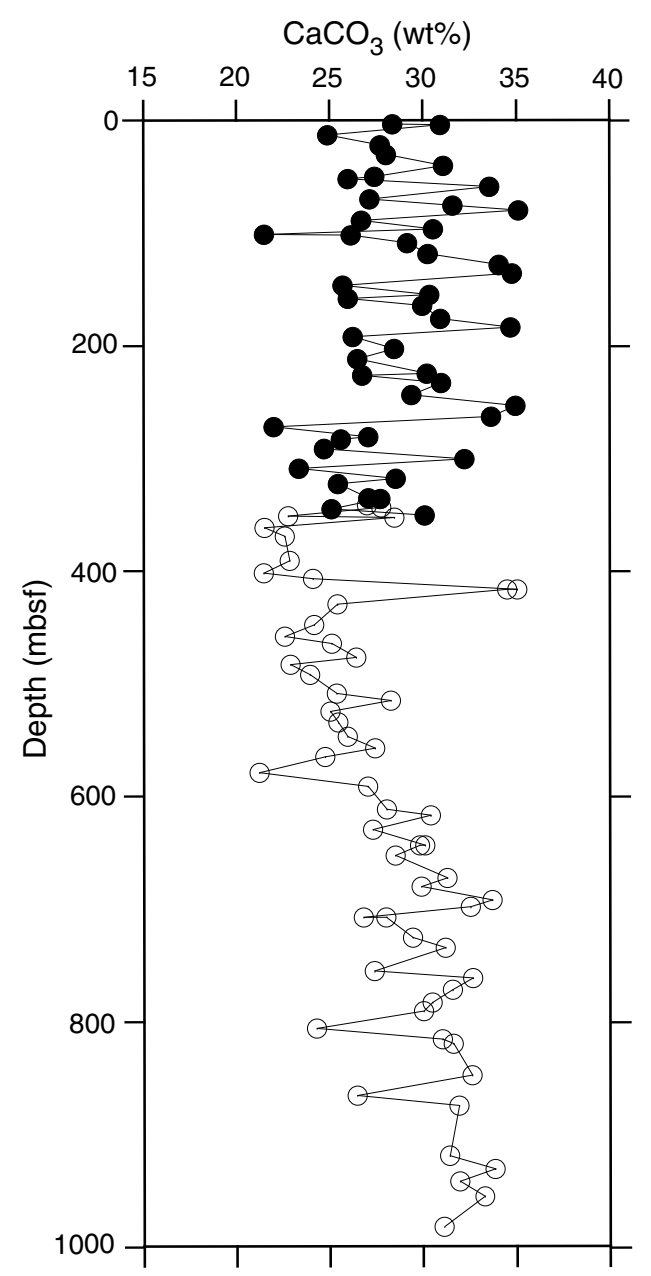


Figure F30. A-C. Plots of calculated total organic carbon (TOC), total nitrogen (TN), and C/N ratio, Holes U1389A (solid circles) and U1389E (open circles).
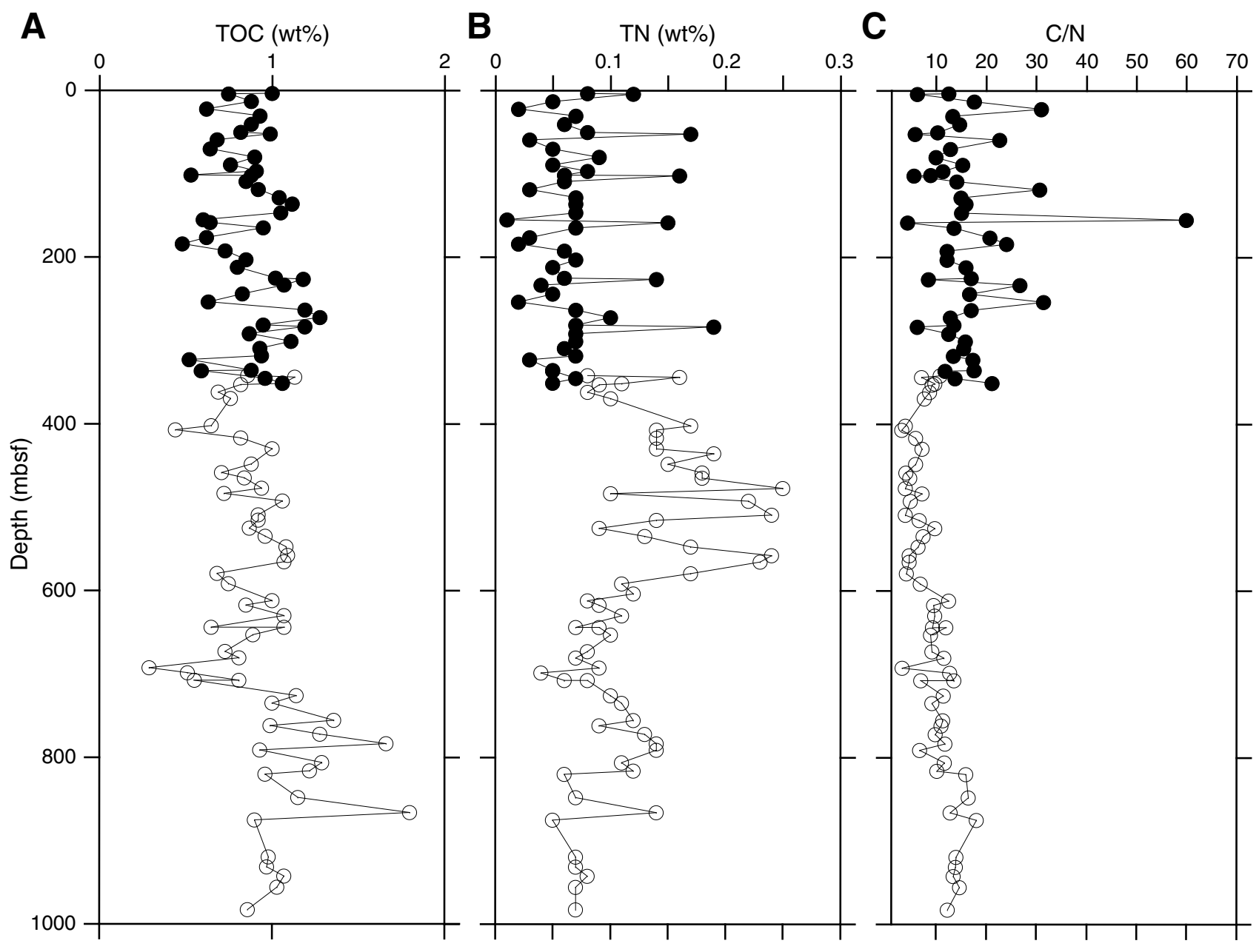

C $\mathrm{C} / \mathrm{N}$ 
Figure F31. A-C. Plots of interstitial water sulfate, ammonium, and alkalinity, Site U1389.

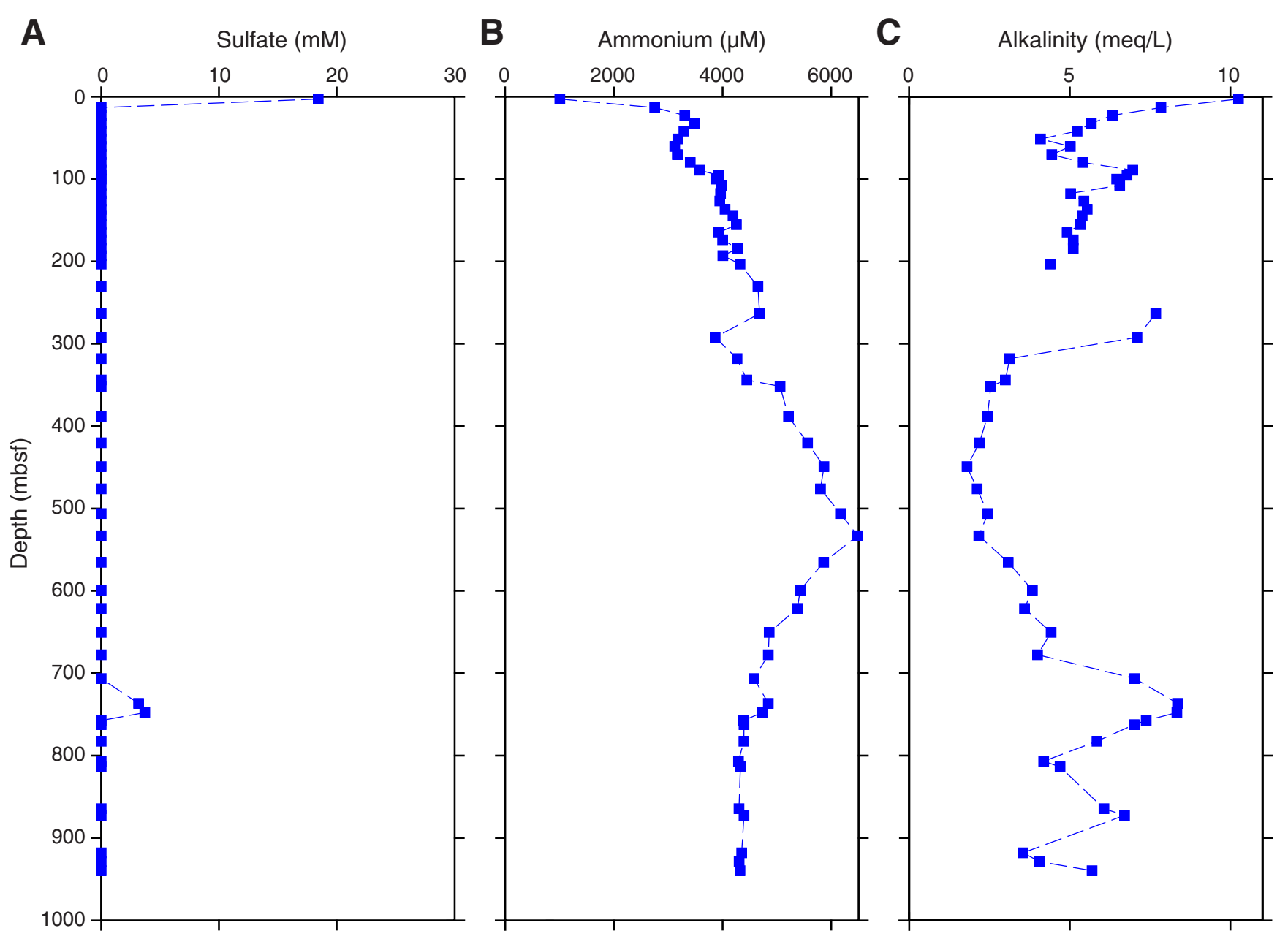


Figure F32. A-C. Plots of interstitial water calcium, magnesium, and potassium, Site U1389.

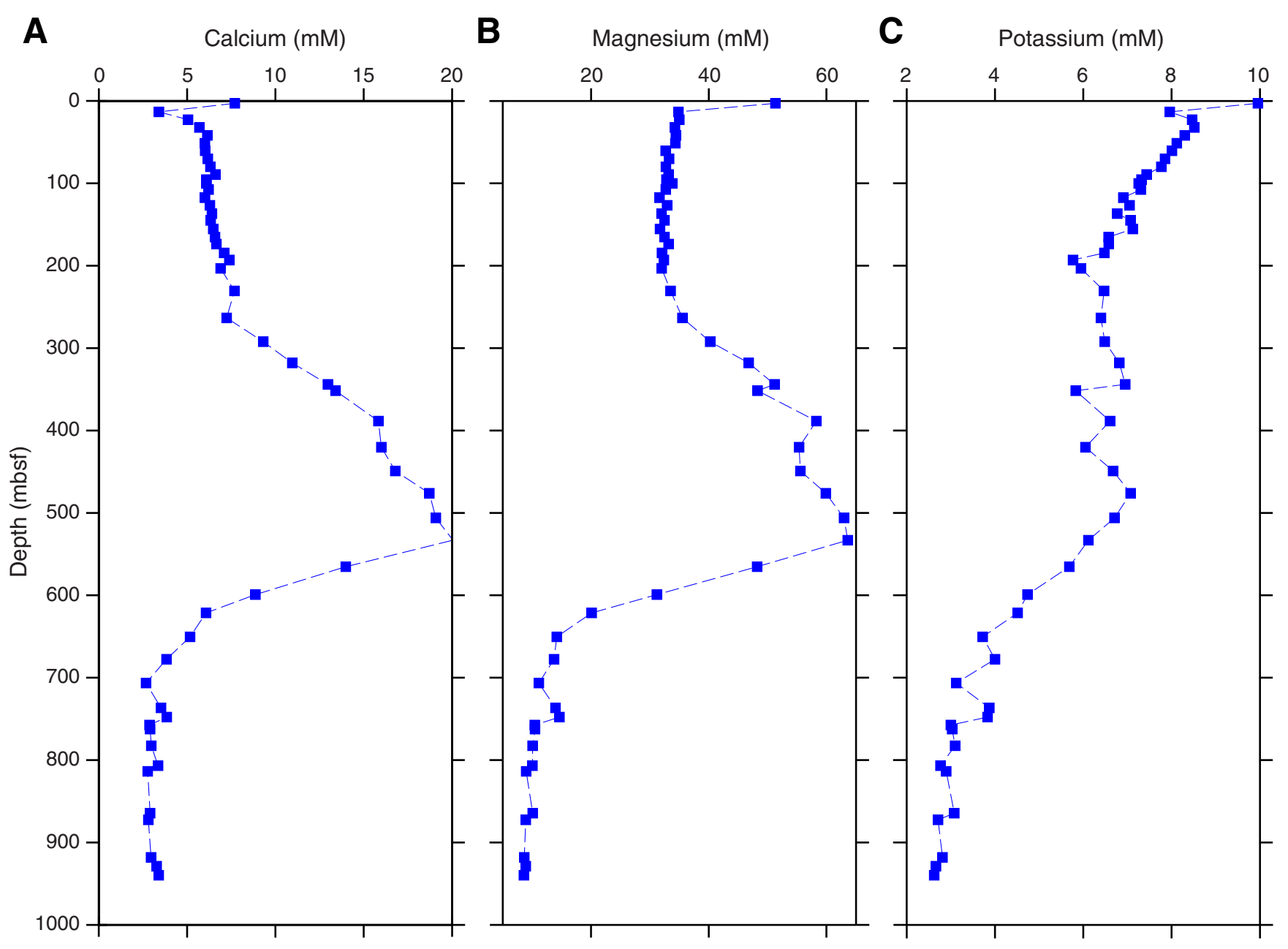


Figure F33. A-C. Plots of interstitial water chloride, sodium, and $\mathrm{Na}^{+} / \mathrm{Cl}^{-}$ratio, Site U1389.

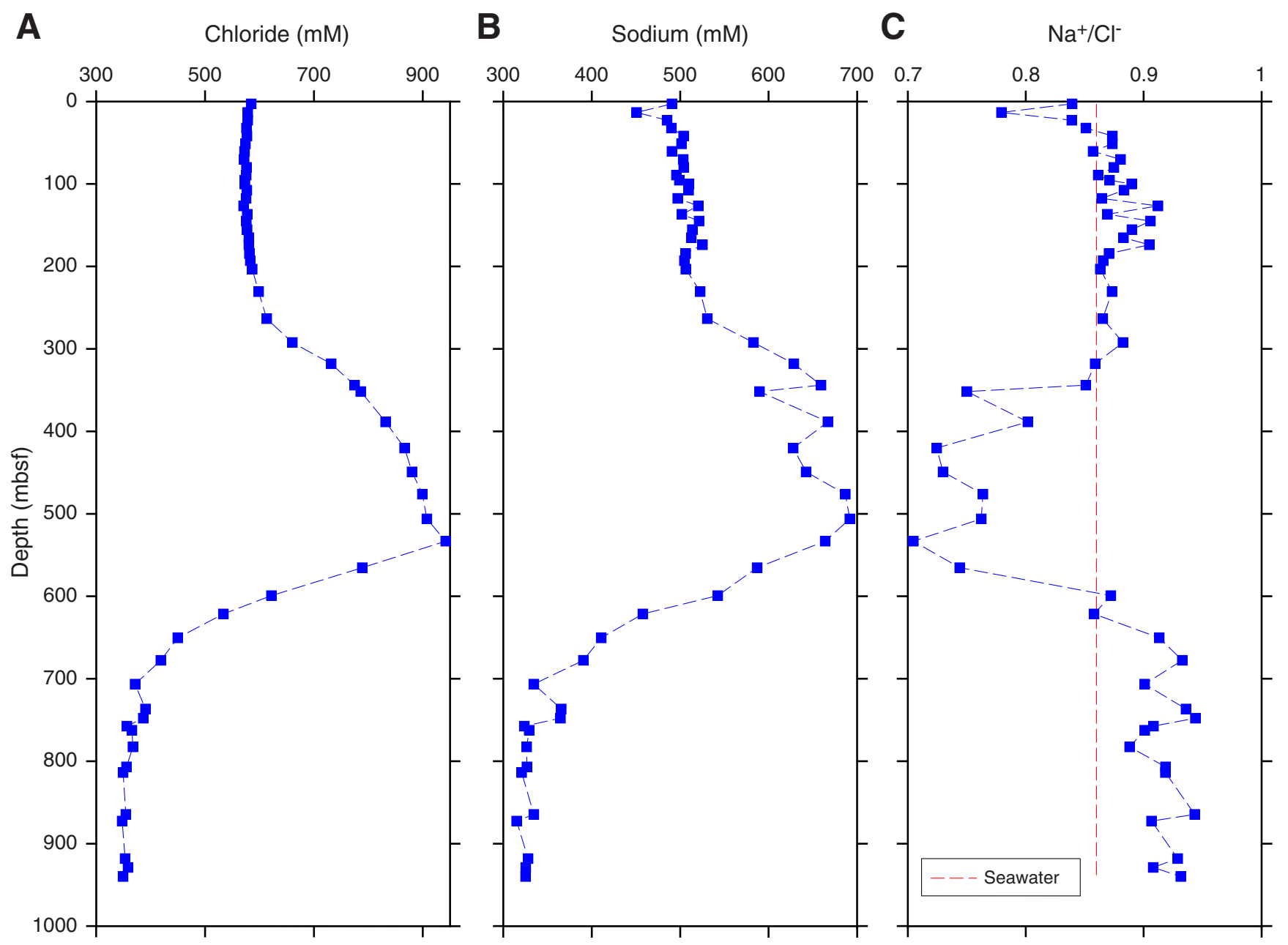


Figure F34. A-C. Plots of interstitial water barium, boron, and iron, Site U1389.

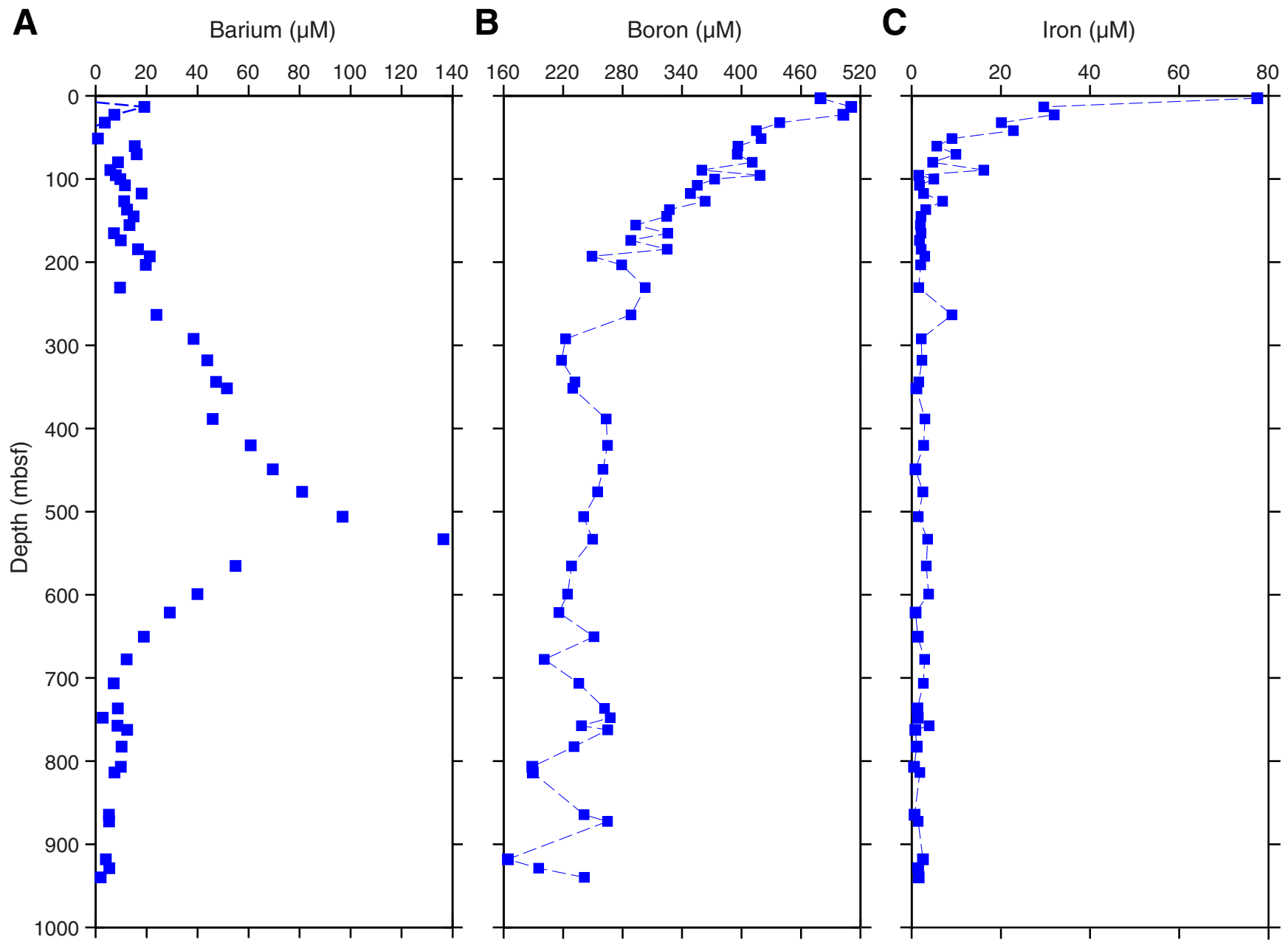


Figure F35. A-C. Plots of interstitial water lithium, silicon, and strontium, Site U1389.

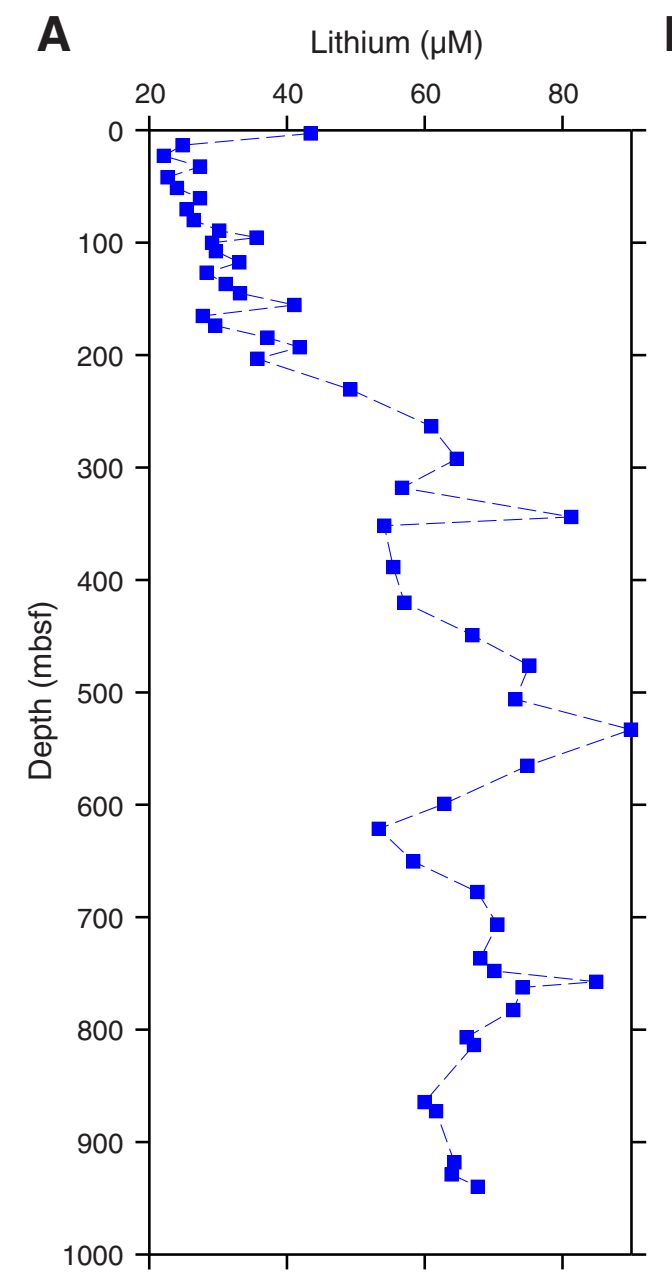

B Silicon $(\mu \mathrm{M})$

C Strontium $(\mu \mathrm{M})$
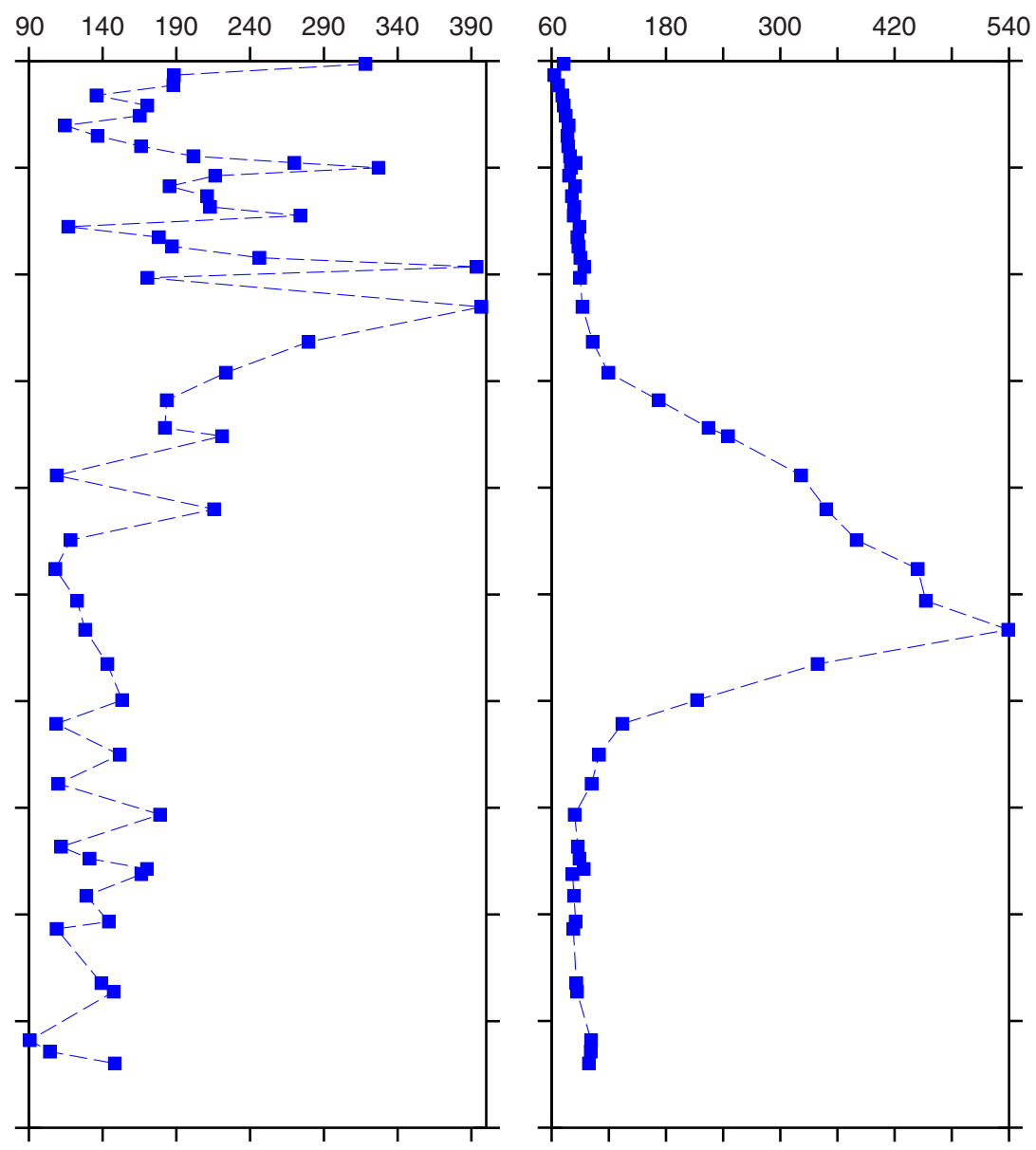
Figure F36. Plots of interstitial water stable isotopes and chloride concentration, Site U1389. VSMOW = Vienna standard mean ocean water.

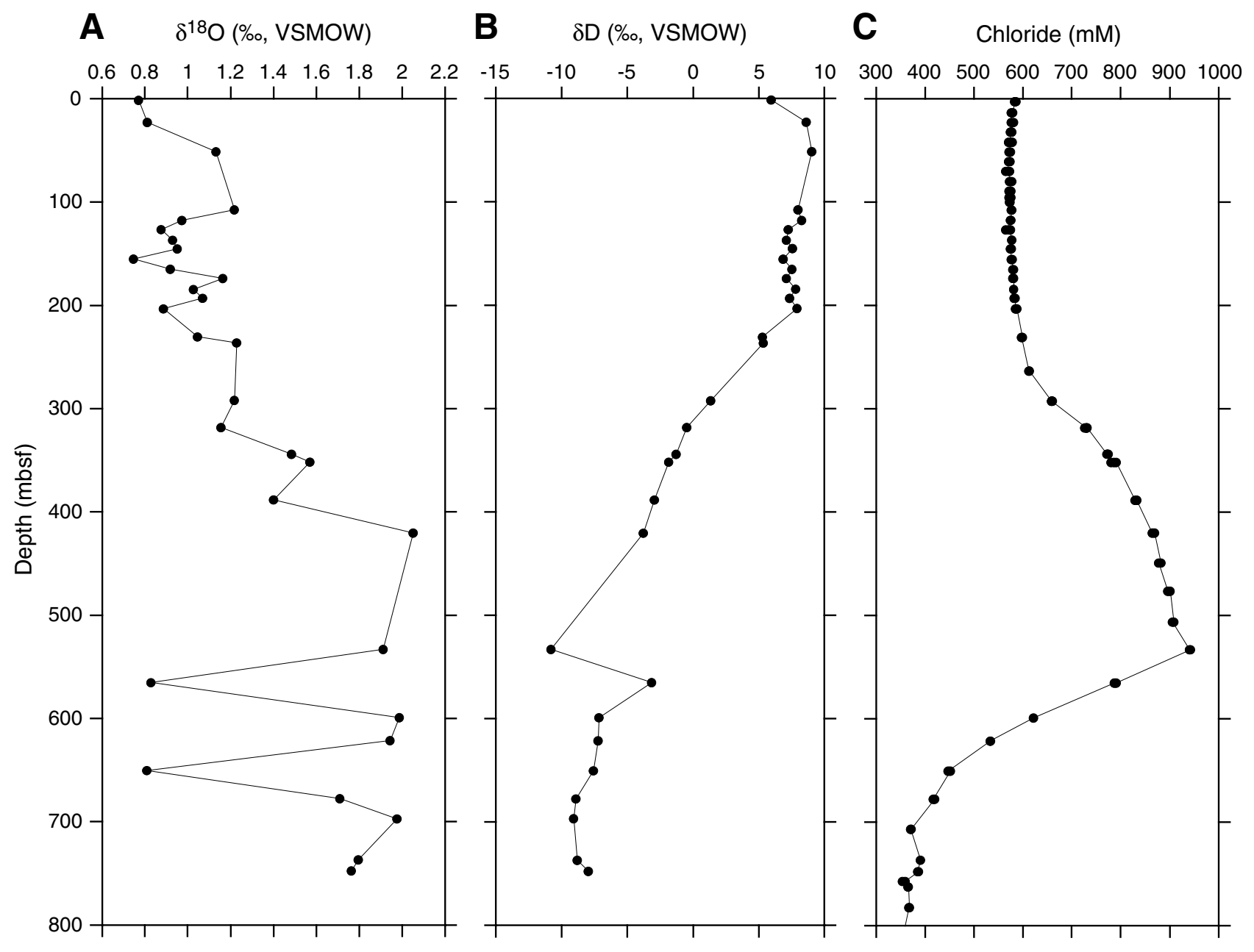


Figure F37. Plot of $\delta^{18} \mathrm{O}$ vs. $\delta \mathrm{D}$, Site U1389. VSMOW = Vienna standard mean ocean water.

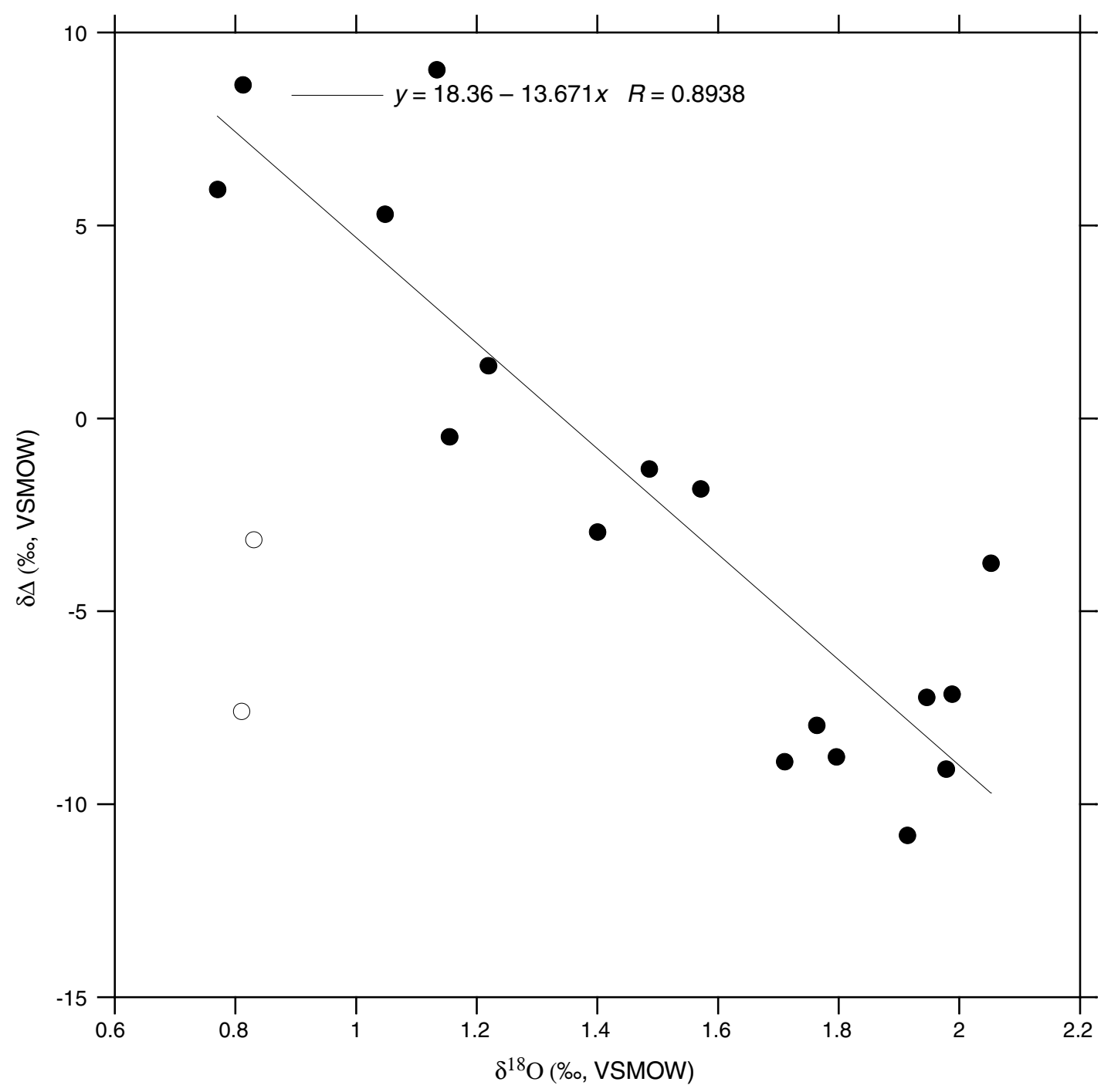


Figure F38. Logging operations summary diagram, Site U1389. FMS = Formation MicroScanner, VSP $=$ vertical seismic profile.
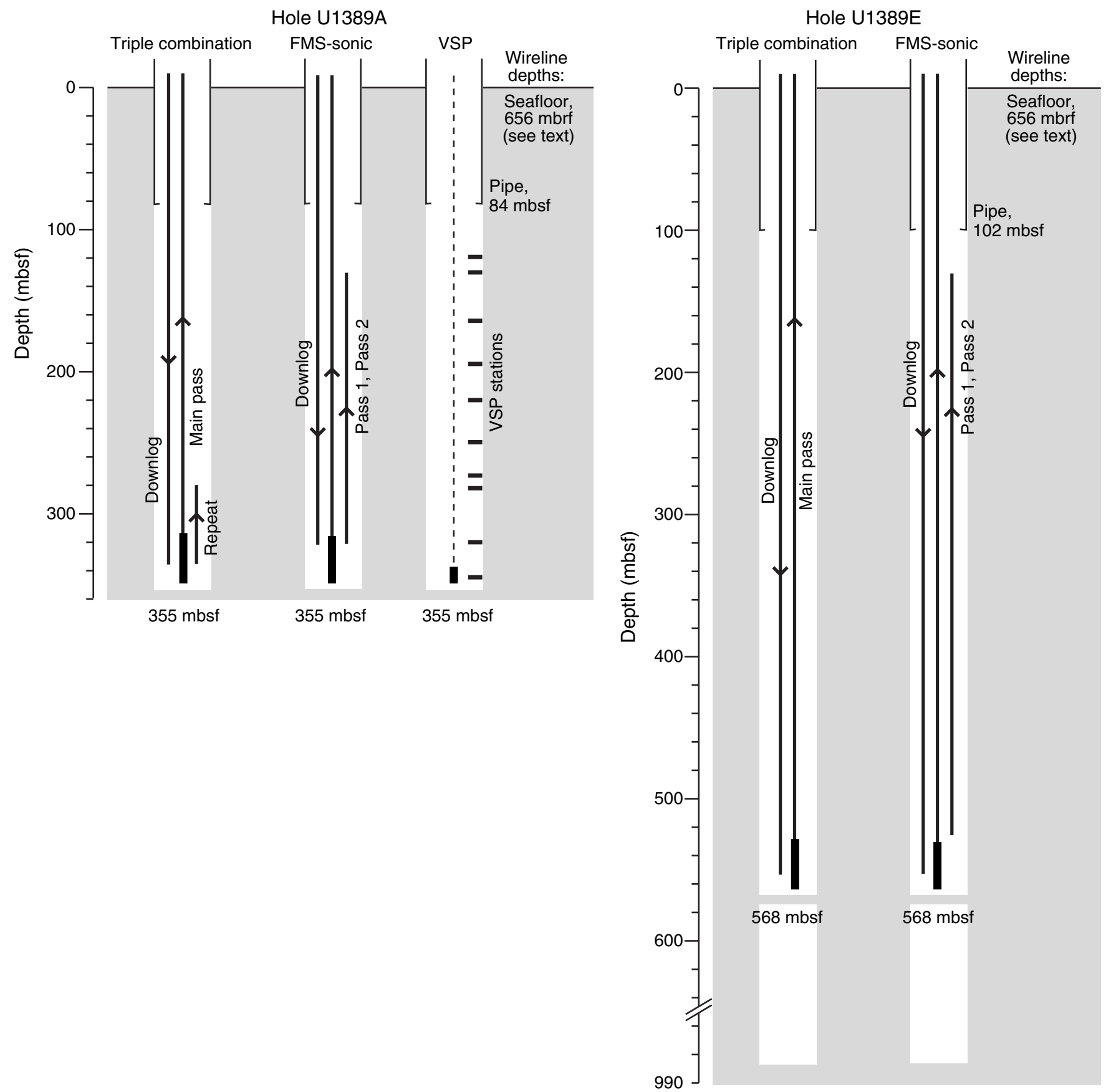
Figure F39. Downhole logs, lithostratigraphic units, and logging units, Hole U1389A. HSGR = standard (total) gamma radiation, $\mathrm{NGR}=$ natural gamma radiation, $\mathrm{MAD}=$ moisture and density discrete samples, $\mathrm{WRMSL}=$ Whole-Round Multisensor Logger, RT = "true" resistivity, RLA5 = deep apparent resistivity, PWC $=P$-wave caliper.

Hole U1389A

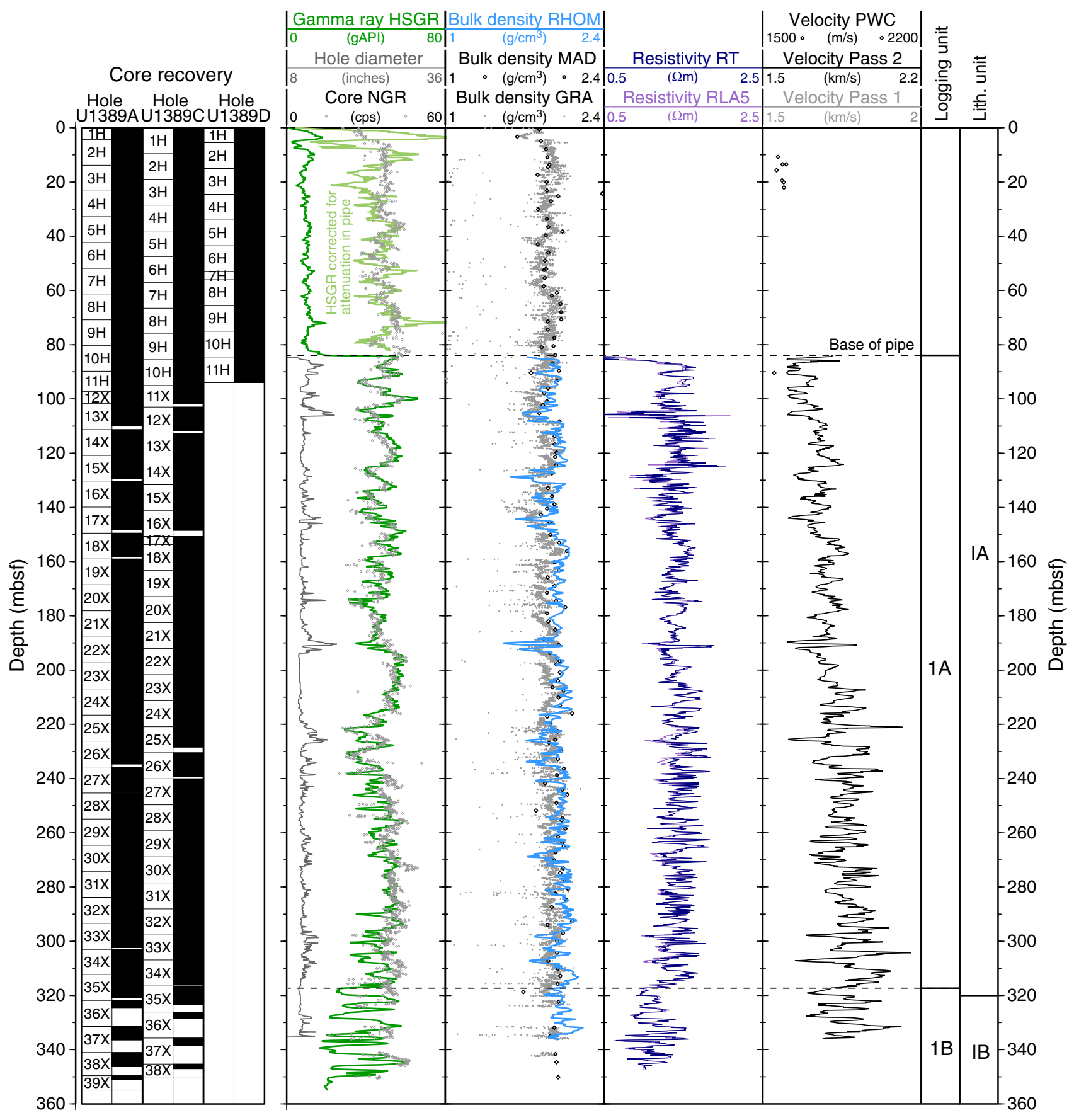


Figure F40. Plots of tides and ship heave, Site U1389. Tides were calculated using Tide Model Driver, a Matlab front end for the Oregon State University Tidal Data Inversion (Egbert and Erofeeva, 2002). Ship heave was derived from acceleration measured by the motion reference unit in the moon pool area. APCT-3 = advanced piston corer temperature tool, FMS = Formation MicroScanner, RMS = root-mean square.

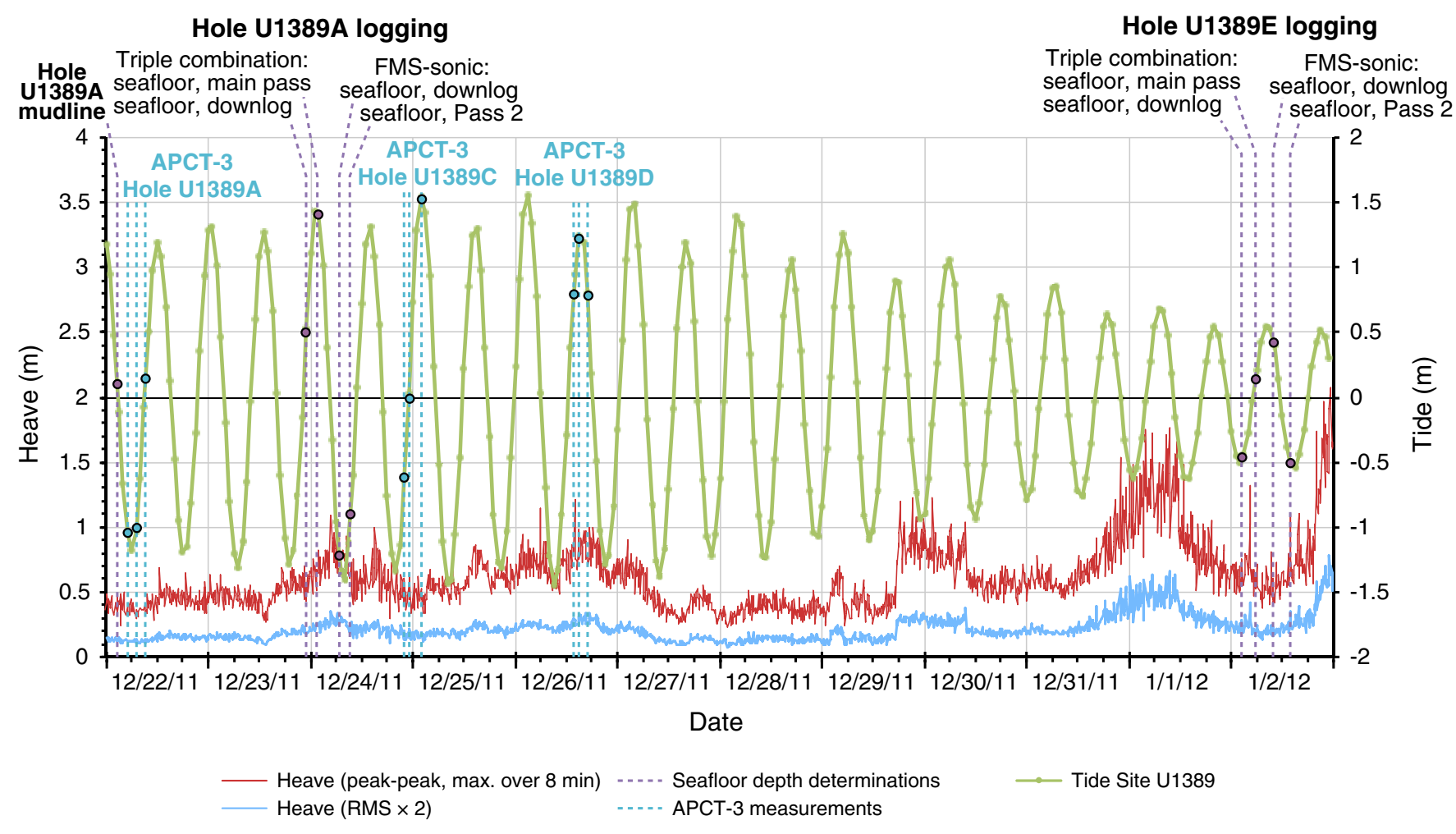


Figure F41. Plot of comparison between the logging standard (total) gamma ray (HSGR) data in Hole U1389A and the (5-point average) natural gamma ray (NGR) data in Holes U1389A- U1389D vs. depth. HSGR data has been normalized separately for the interval below and above the end of the drill string.

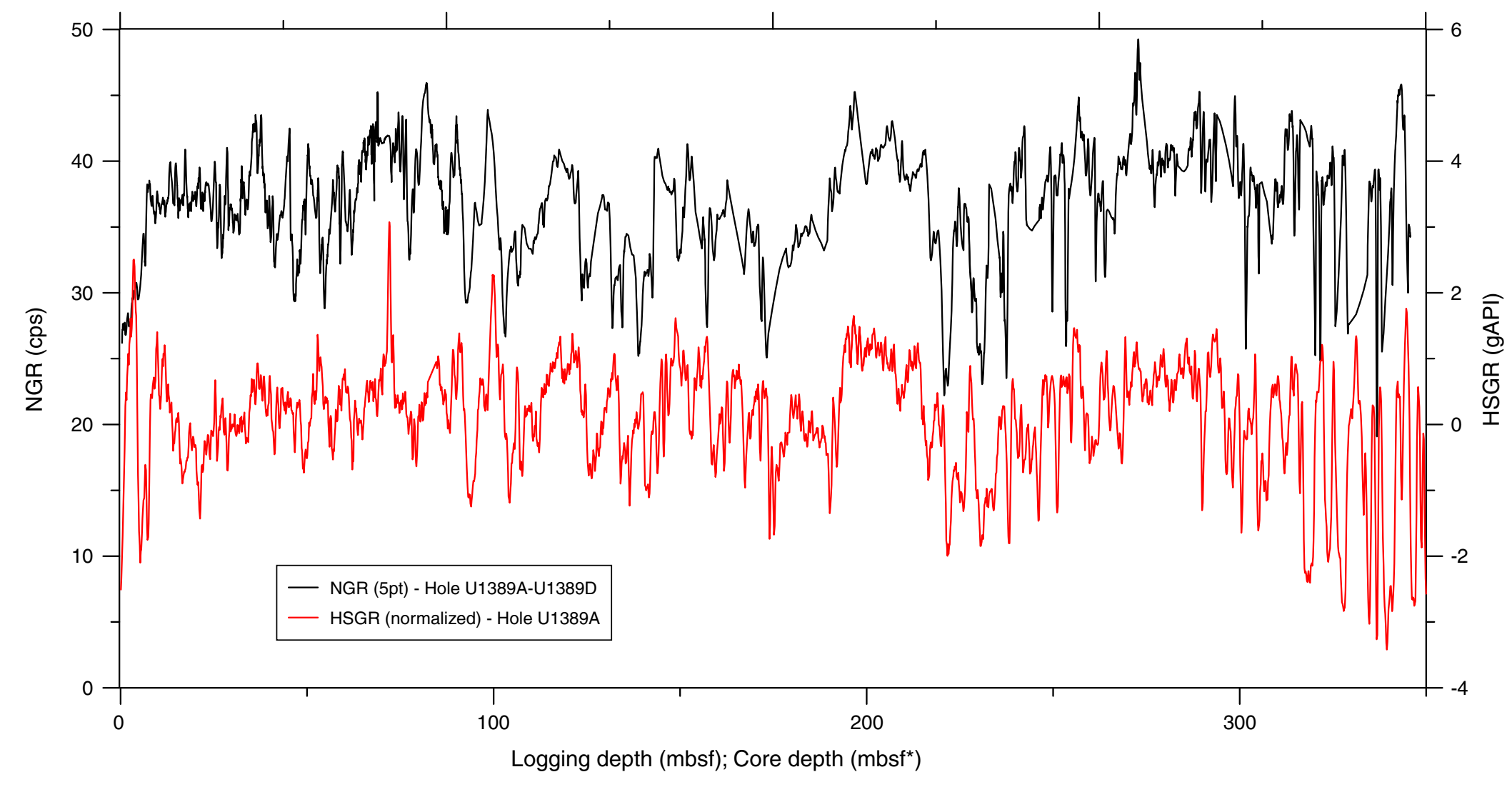


Figure F42. Downhole logs, lithostratigraphic units, and logging units, Hole U1389E. HSGR = standard (total) gamma radiation, $\mathrm{NGR}=$ natural gamma radiation, $\mathrm{RHOM}=$ bulk density, $\mathrm{MAD}=$ moisture and density discrete samples, RT $=$ "true" resistivity, RLA5 $=$ deep apparent resistivity, $\mathrm{PWC}=P$-wave caliper.

Hole U1389E

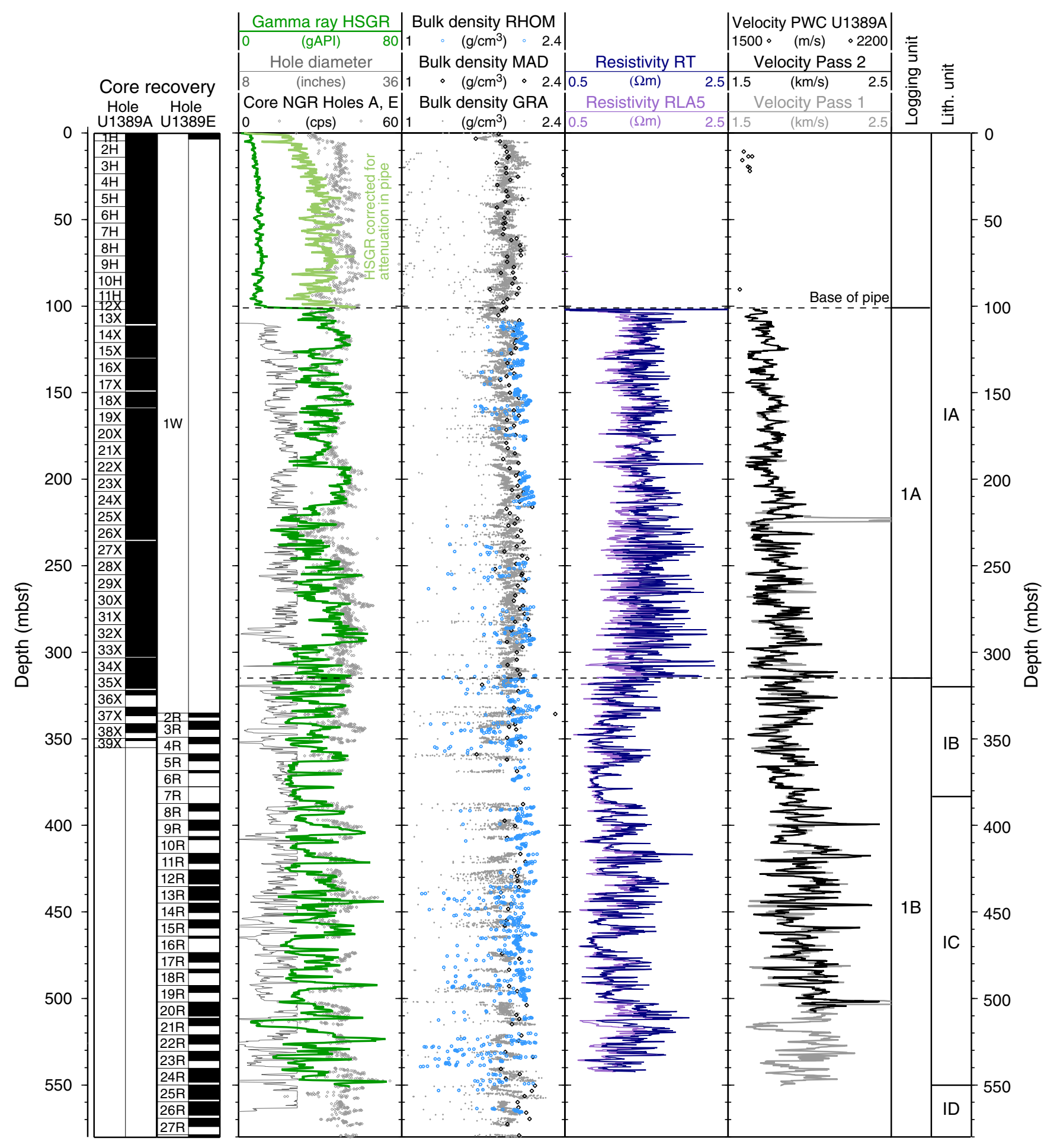


Figure F43. Natural gamma radiation (NGR) logs, lithostratigraphic units, and logging units, Hole U1389A. HSGR = standard (total) gamma radiation .

Hole U1389A

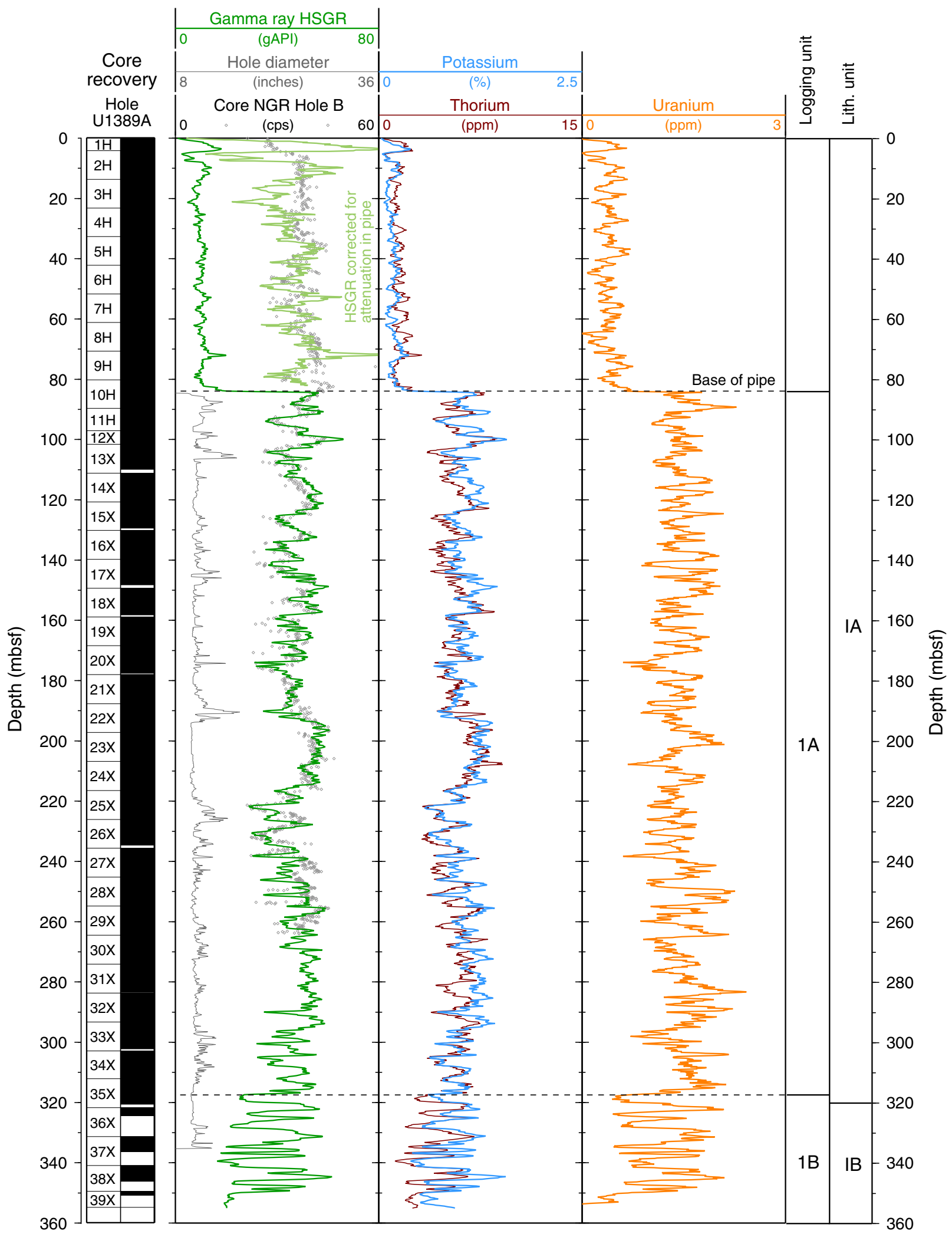


Figure F44. Natural gamma radiation (NGR) logs, lithostratigraphic units, and logging units, Hole U1389E. HSGR = standard (total) gamma radiation .

Hole U1389E

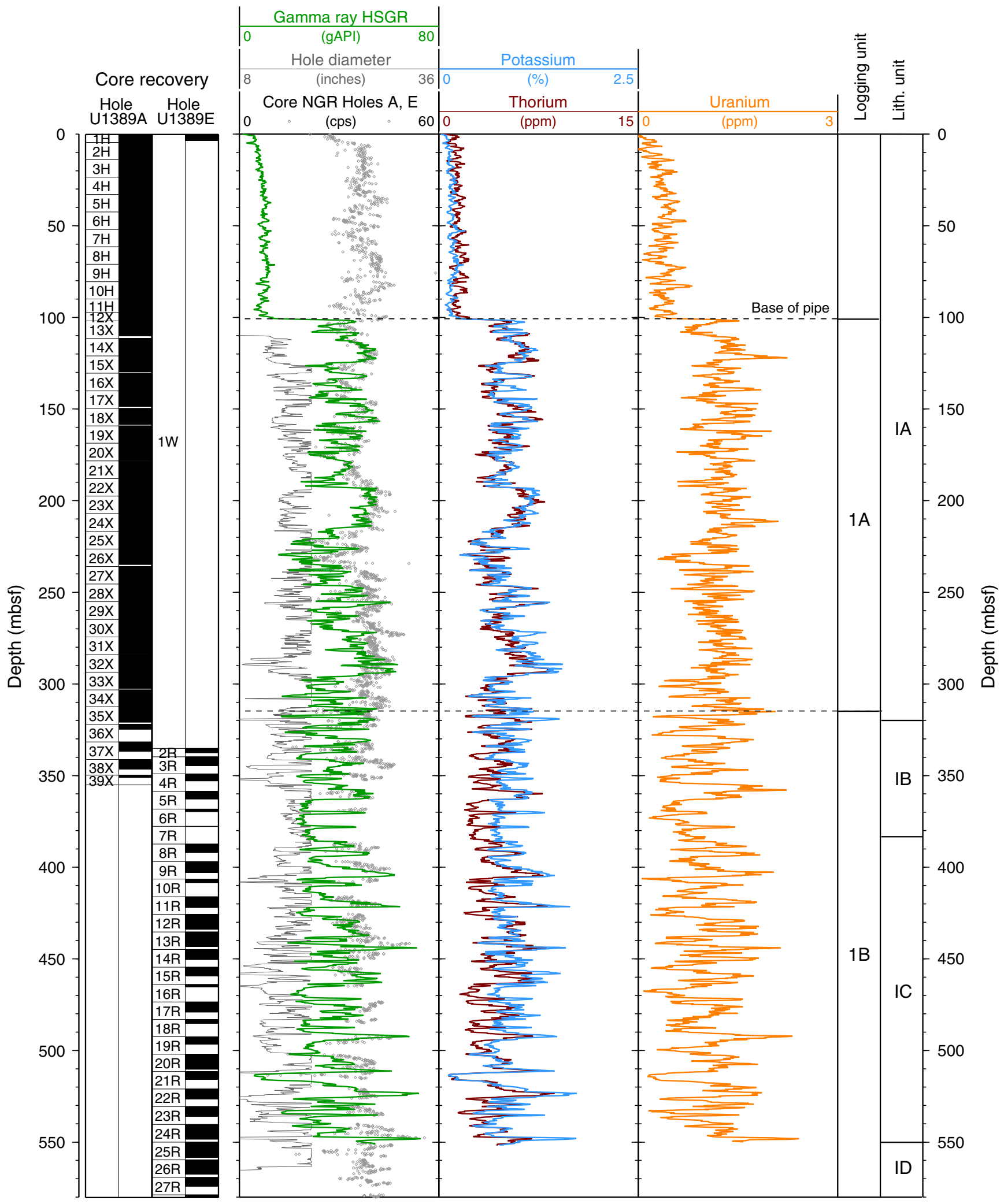


Figure F45. Comparison of downhole logs in Holes U1389A (dark lines) and U1389E (light lines). The differences between the logs are mostly caused by the contrast in borehole diameter between the two holes. This data set provides important quality control information for log data in wide boreholes. HSGR = standard (total) gamma radiation, MAD = moisture and density discrete samples, RLA5 = deep apparent resistivity.

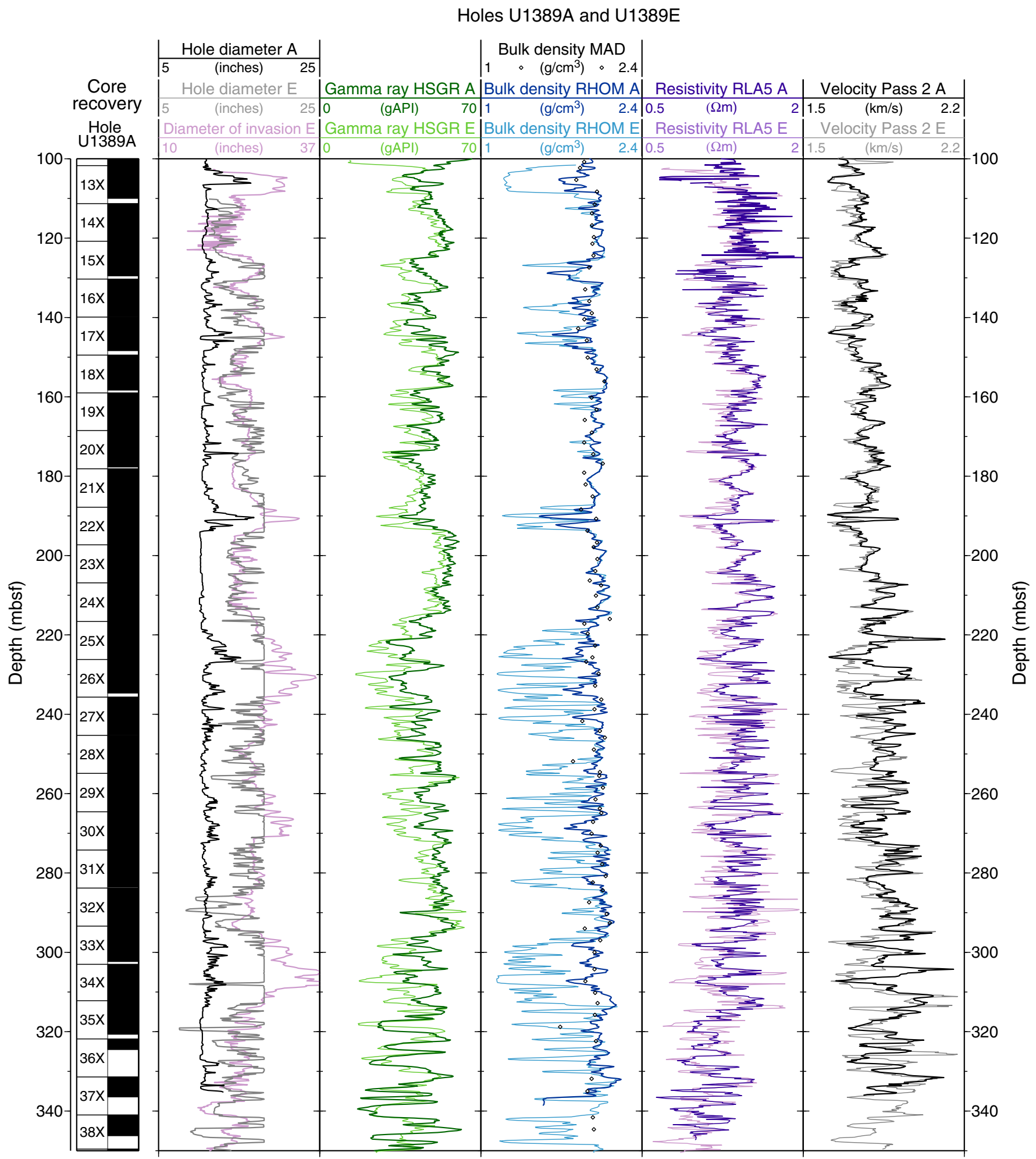


Figure F46. Comparison of downhole logs and lithology, Hole U1389A. Comparison indicates that sand-rich layers have lower gamma radiation and are less resistive than the clay-rich beds. Clay-rich beds appear to be preferentially recovered in cores. HSGR $=$ standard (total) gamma radiation, GRA = gamma ray attenuation, RT = "true" resistivity, RLA5 = deep apparent resistivity, FMS = Formation MicroScanner. n.m. = nannofossil mud, s.m. = silty mud, s.s. = silty sand.

Hole U1389A

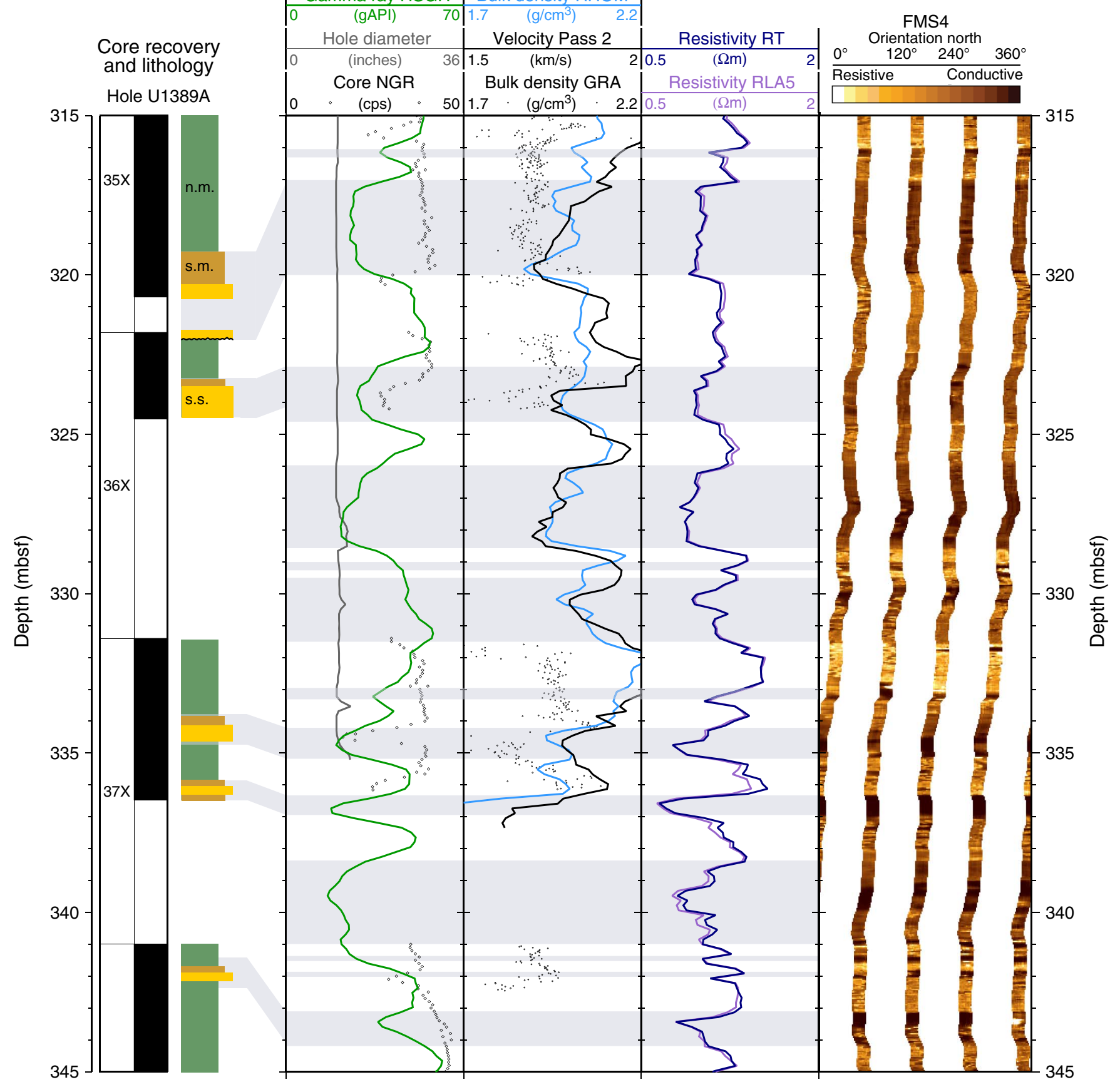


Figure F47. Plots of vertical seismic profile waveforms and one-way traveltime picks, Site U1386.

One-way traveltime (s)

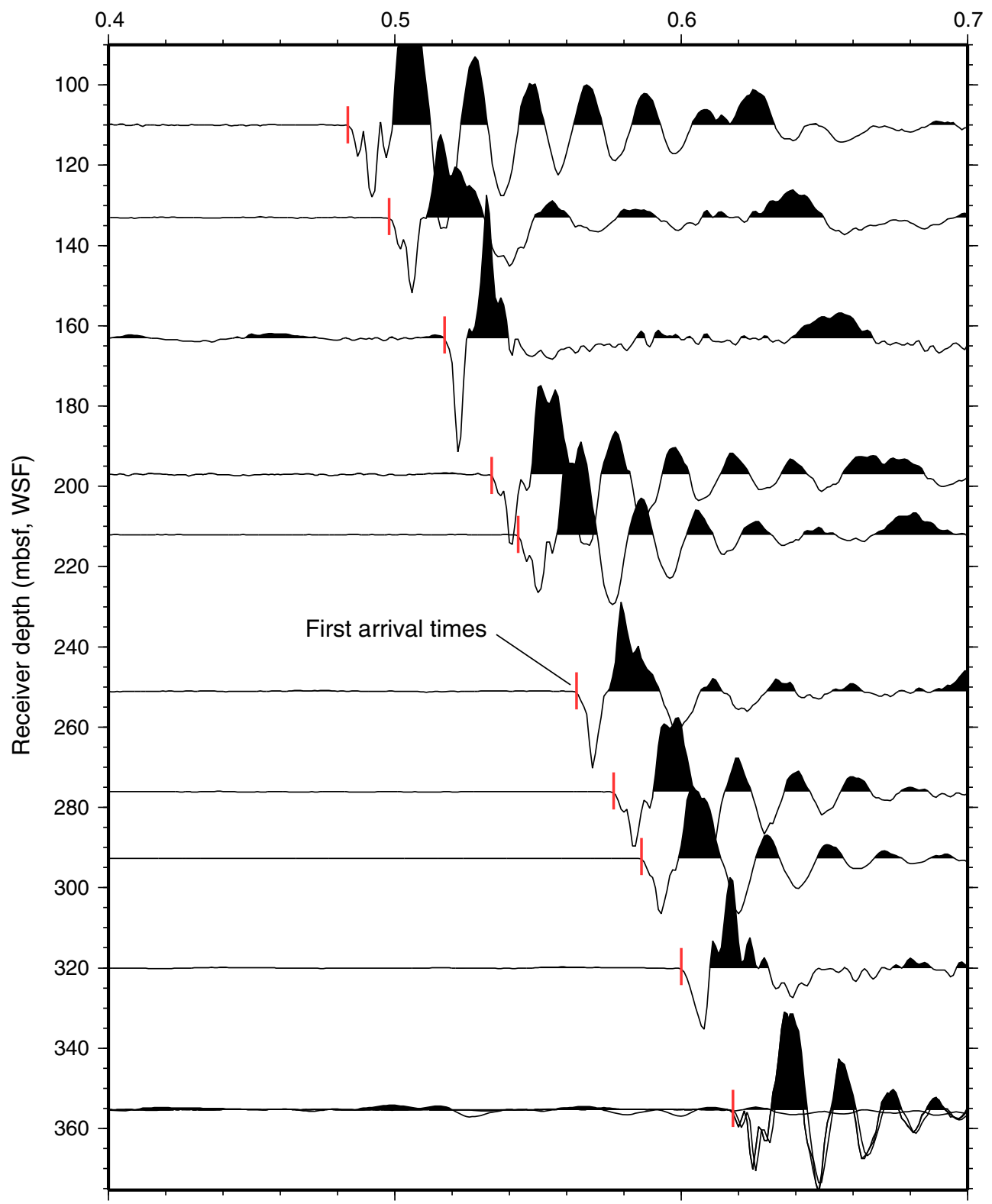


Figure F48. Plots of heat flow calculations, Site U1386. A. Sediment temperatures in Holes U1389A (blue), U1389C (purple), and U1389D (orange). B. Thermal conductivity data from Hole U1389A (circles) with calculated thermal resistance (solid line). C. Bullard plot of heat flow calculated from a linear fit of the temperature data.

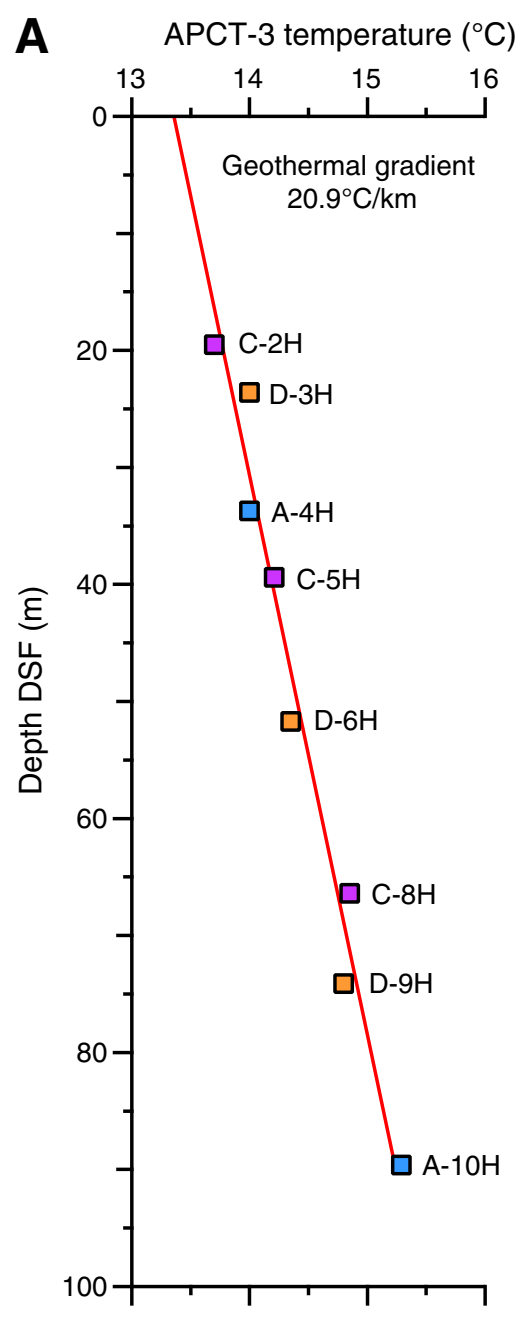

B Thermal conductivity $(\mathrm{W} /[\mathrm{m} \cdot \mathrm{K}])$

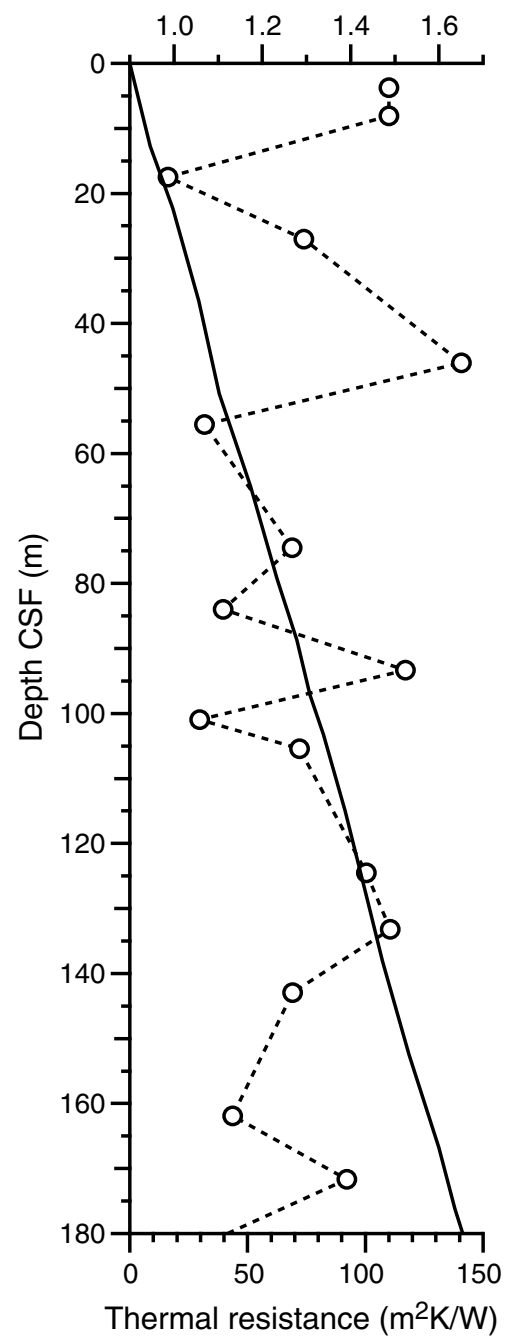

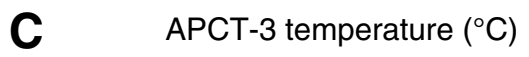

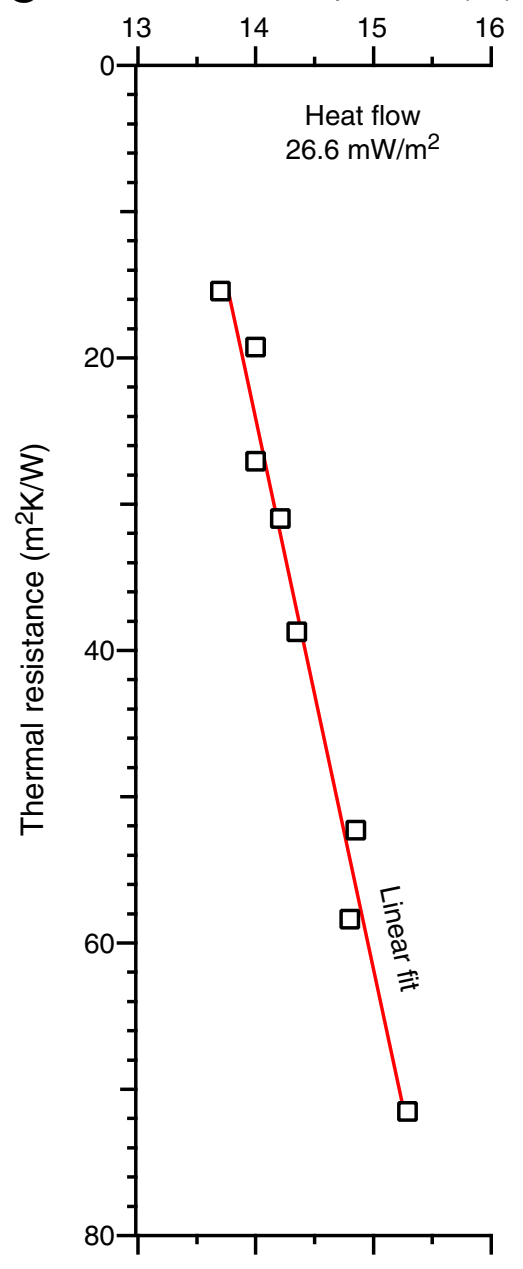


Figure F49. Plots of magnetic susceptibility vs. composite depth, Site U1389. Susceptibility values for Holes U1389B-U1389E are shifted for display purposes in the lower panel. The data are shown only for the multicored intervals. A. 0-40 mcd. (Continued on next eight pages.)

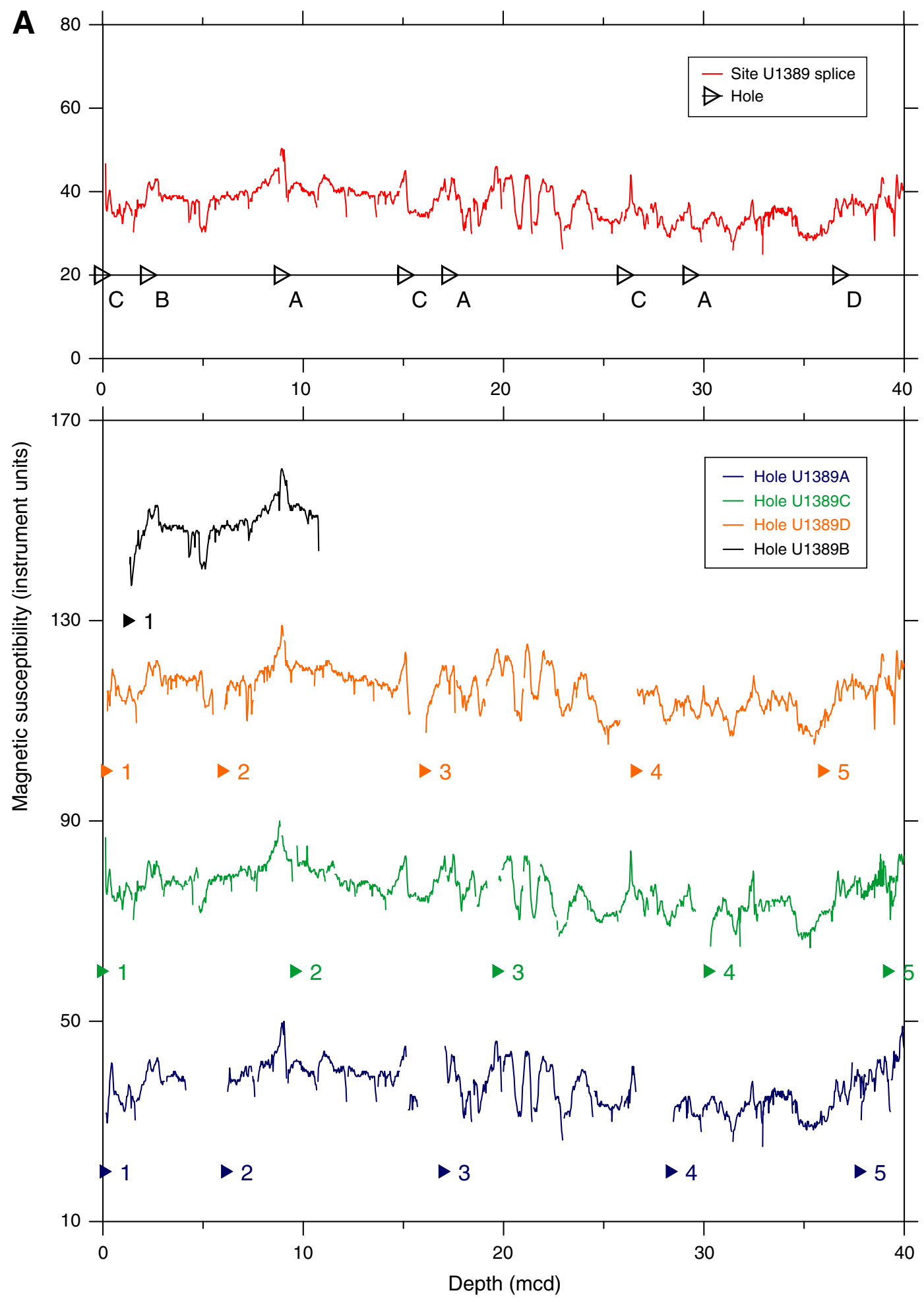


Figure F49 (continued). B. $40-80 \mathrm{mcd}$. (Continued on next page.)
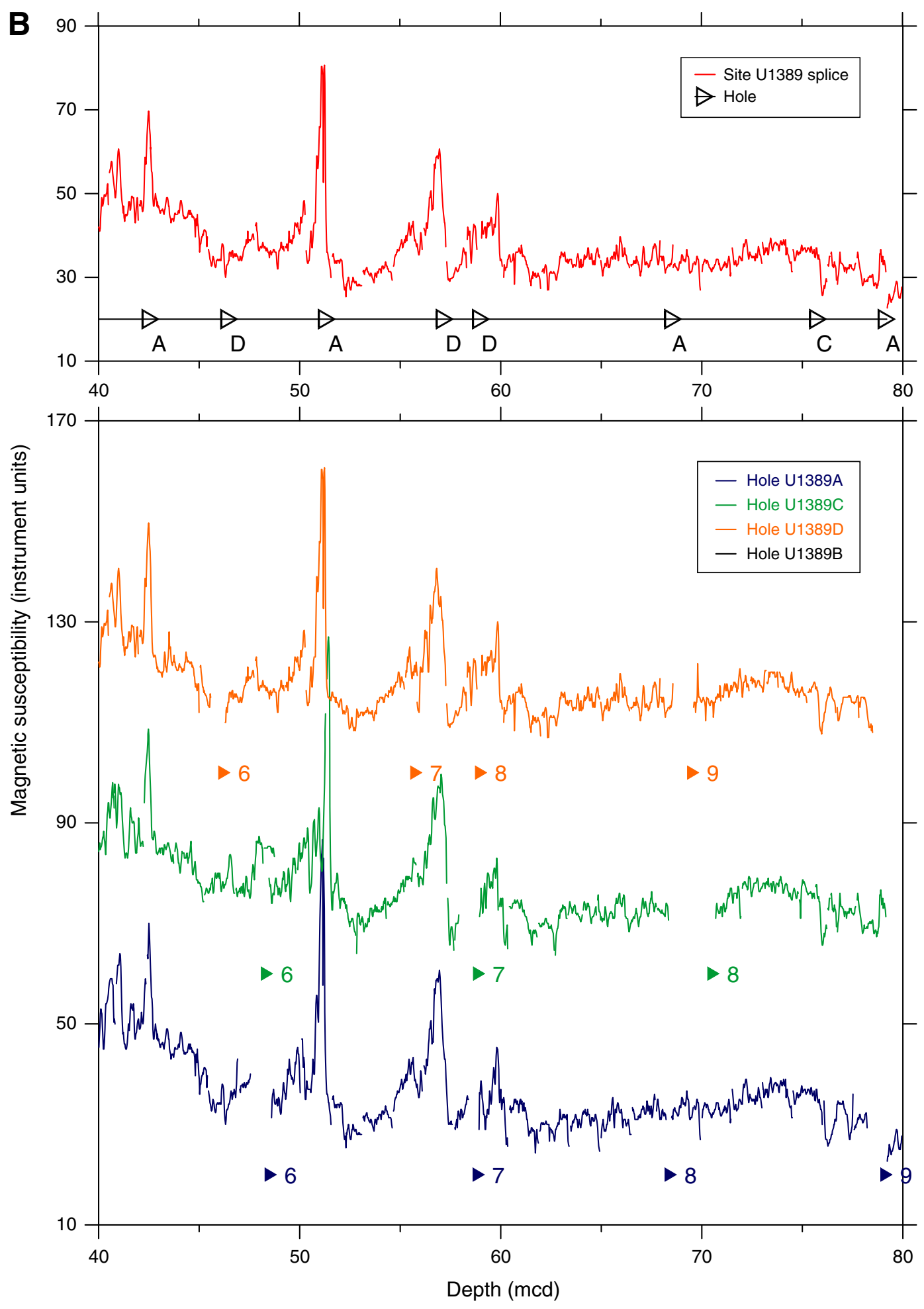
Figure F49 (continued). C. 80-120 mcd. (Continued on next page.)
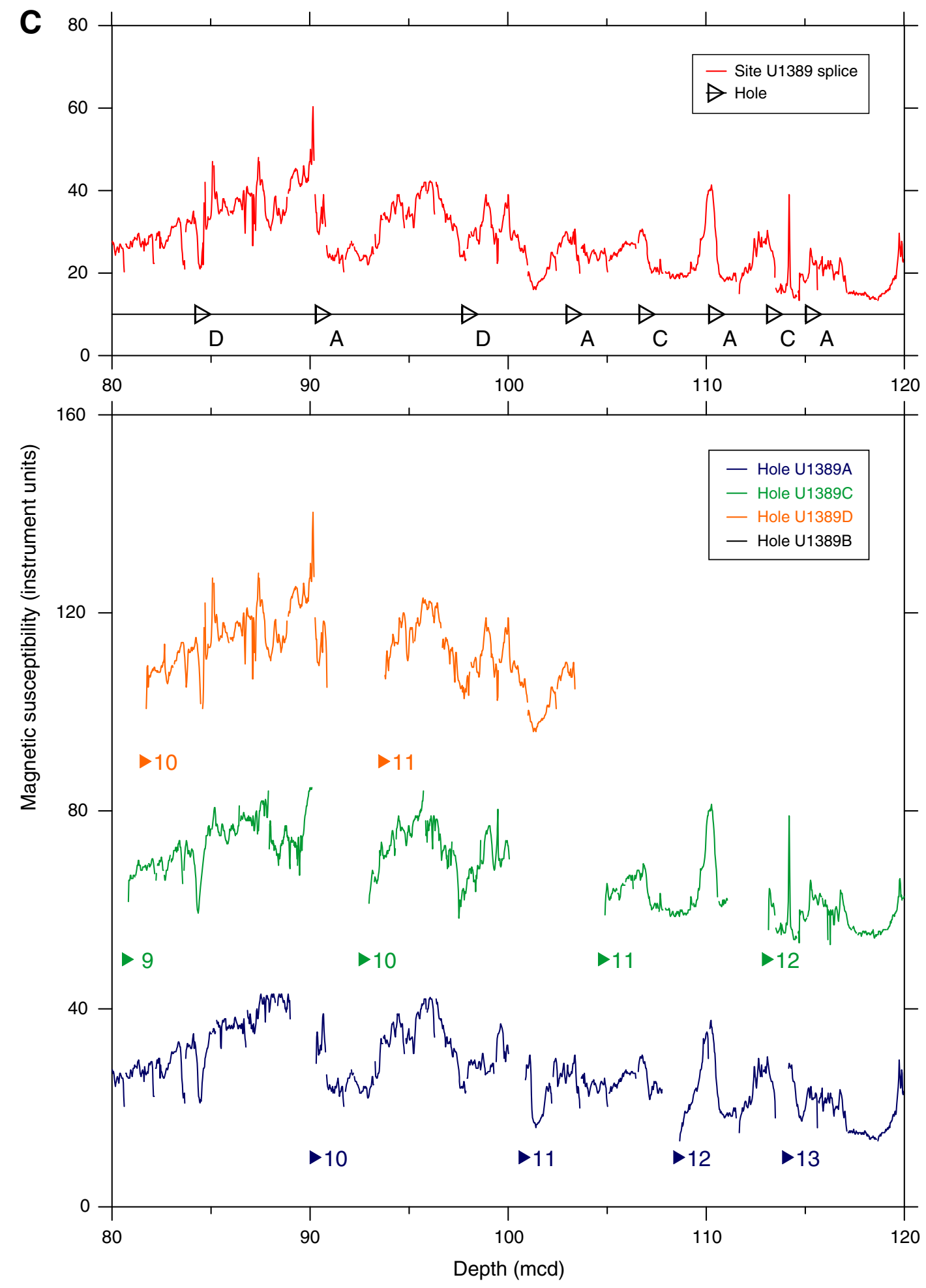
Figure F49 (continued). D. 120-160 mcd. (Continued on next page.)
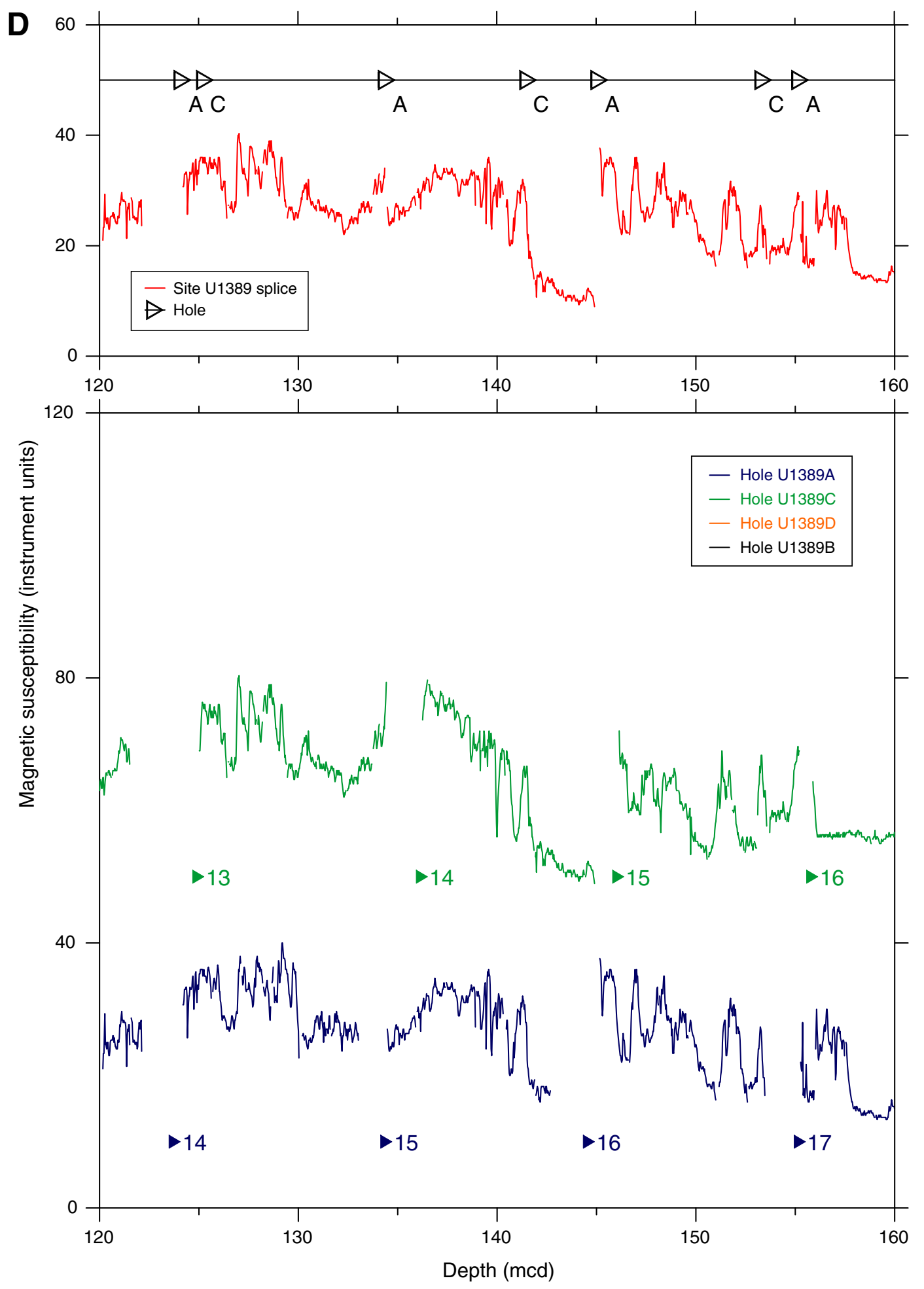
Figure F49 (continued). E. 160-200 mcd. (Continued on next page.)
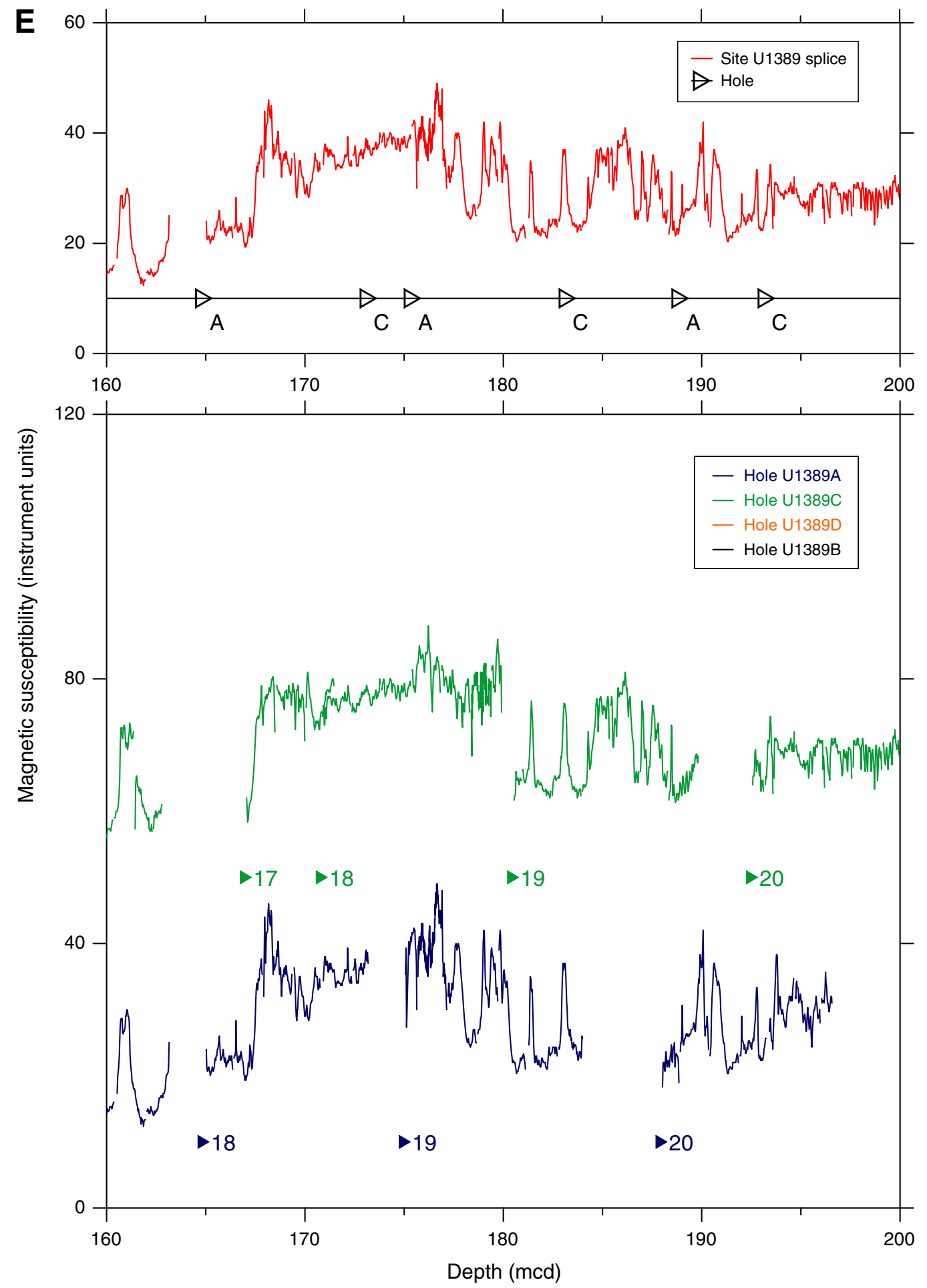
Figure F49 (continued). F. 200-240 mcd. (Continued on next page.)
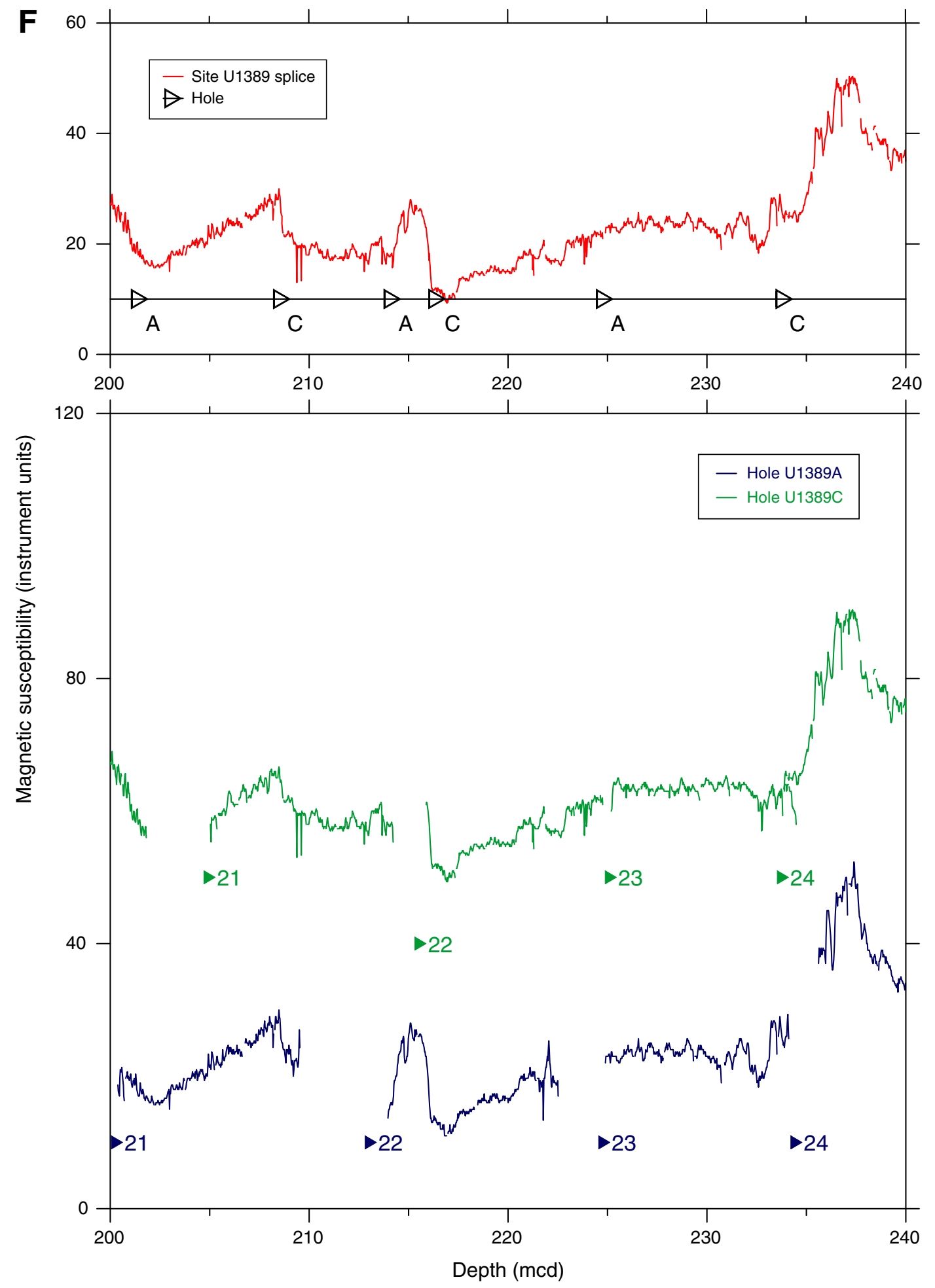
Figure F49 (continued). G. 240-280 mcd. (Continued on next page.)
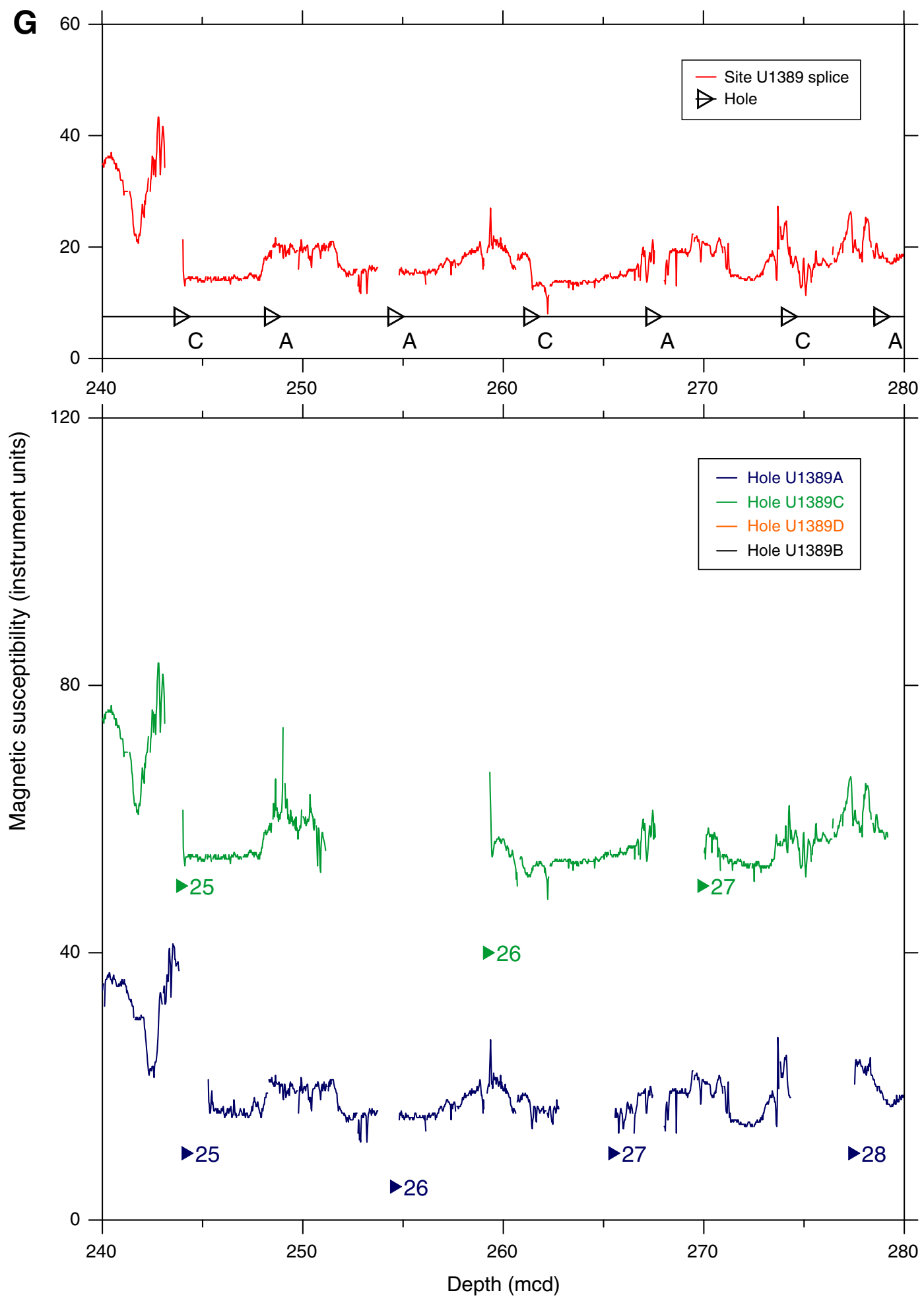
Figure F49 (continued). H. 280-320 mcd. (Continued on next page.)

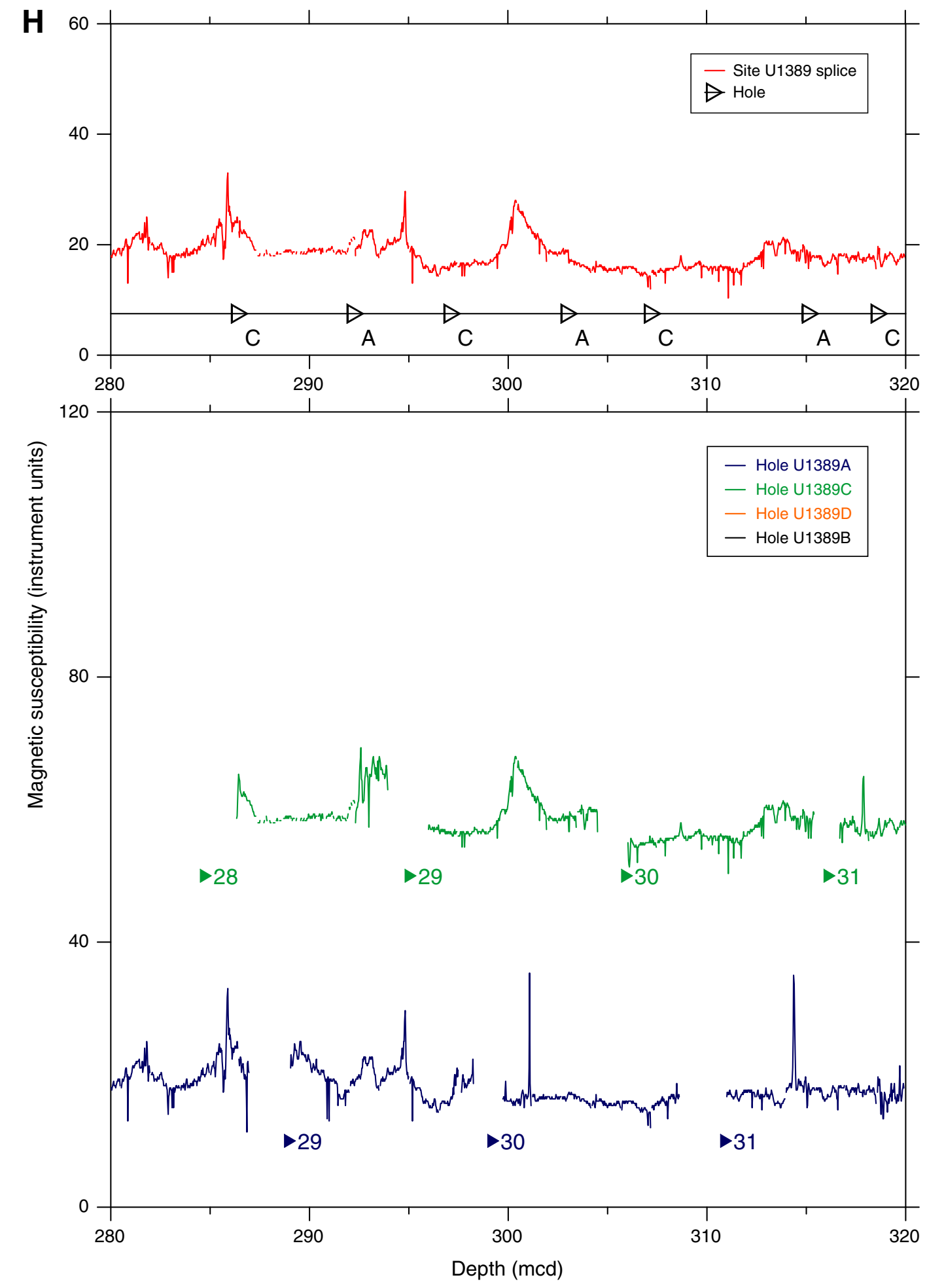


Figure F49 (continued). I. 320-360 mcd. (Continued on next page.)
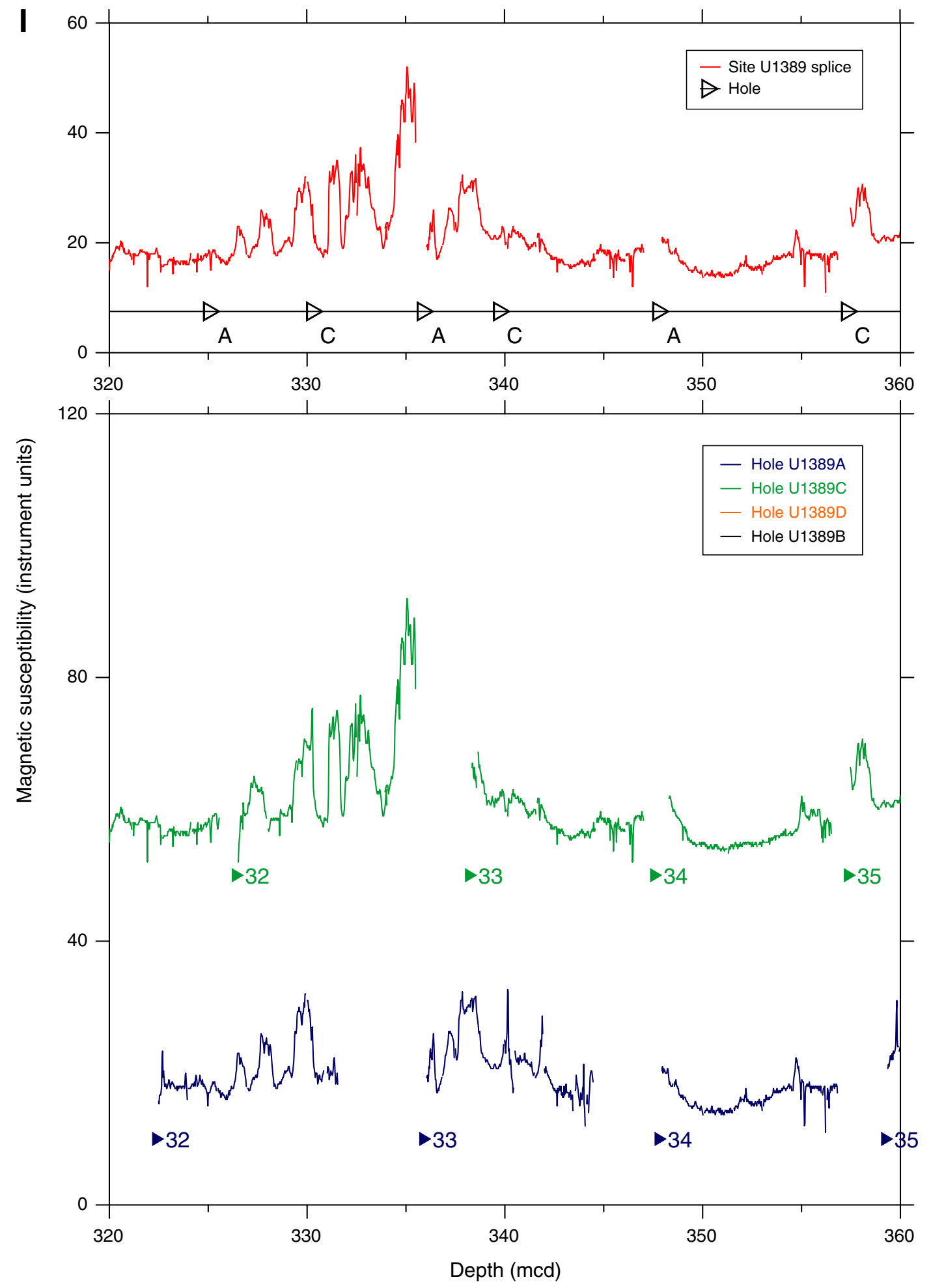
Figure F49 (continued). J. 360-400 mcd.
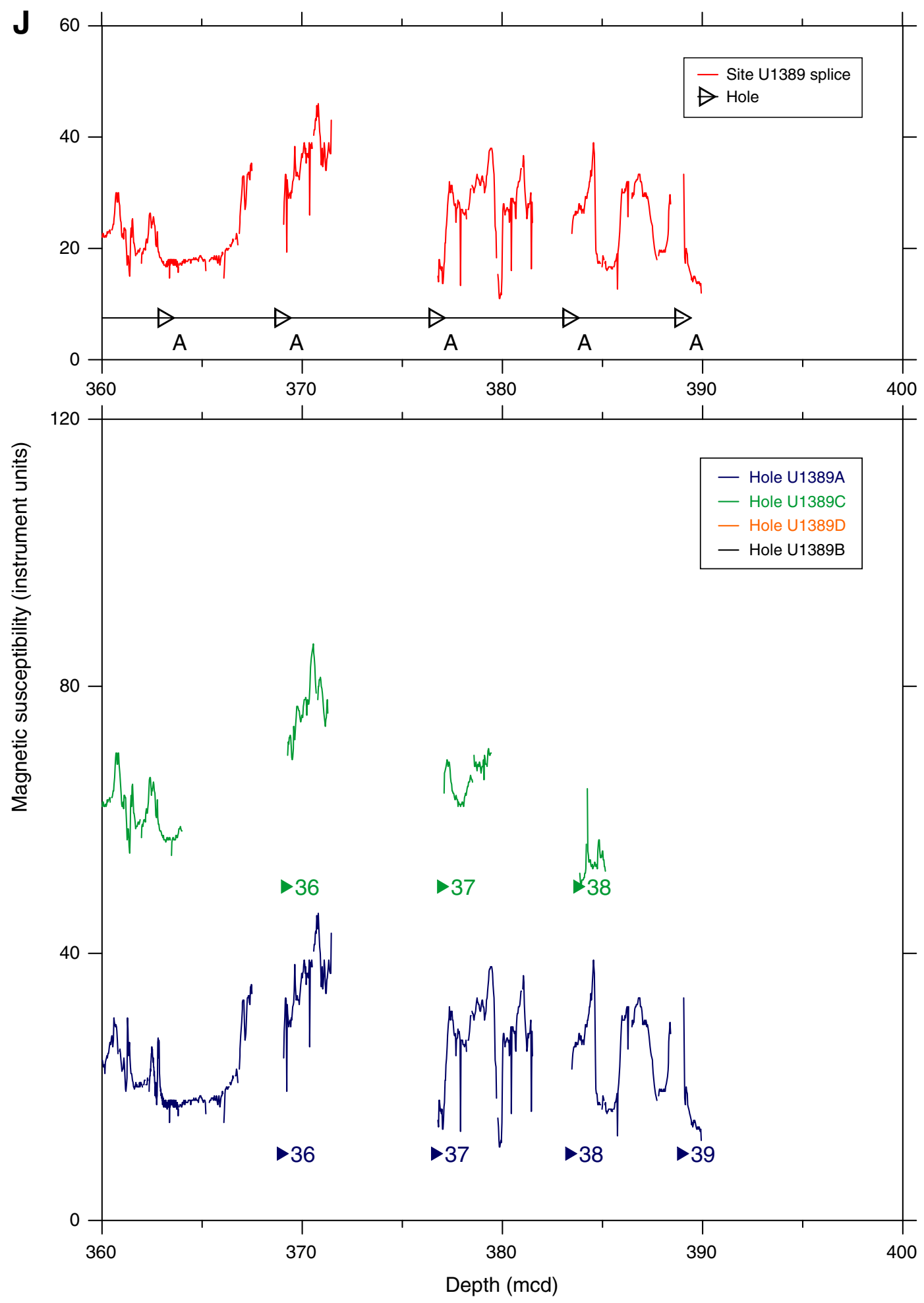
Figure F50. Plots of core top depths for mbsf vs. mcd, Site U1389. Red lines are best-fit slope.

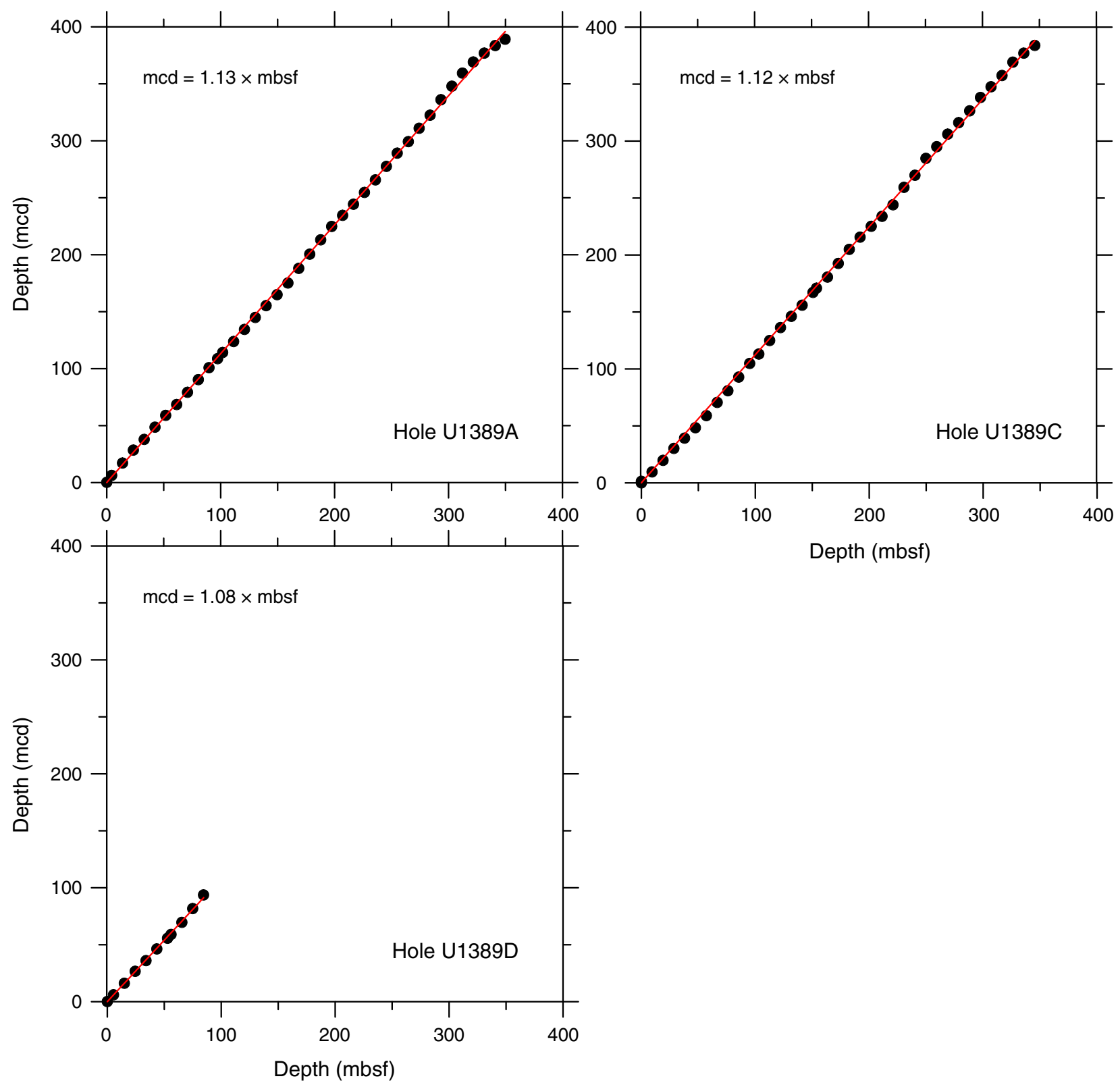


Figure F51. Plot of core top depths for mcd vs. mbsf, Holes U1389A-U1389D. Line fits through the core top depths of all holes give an estimate of the amount the mcd scale has to be compressed to derive the mbsf* scale. $^{*}$

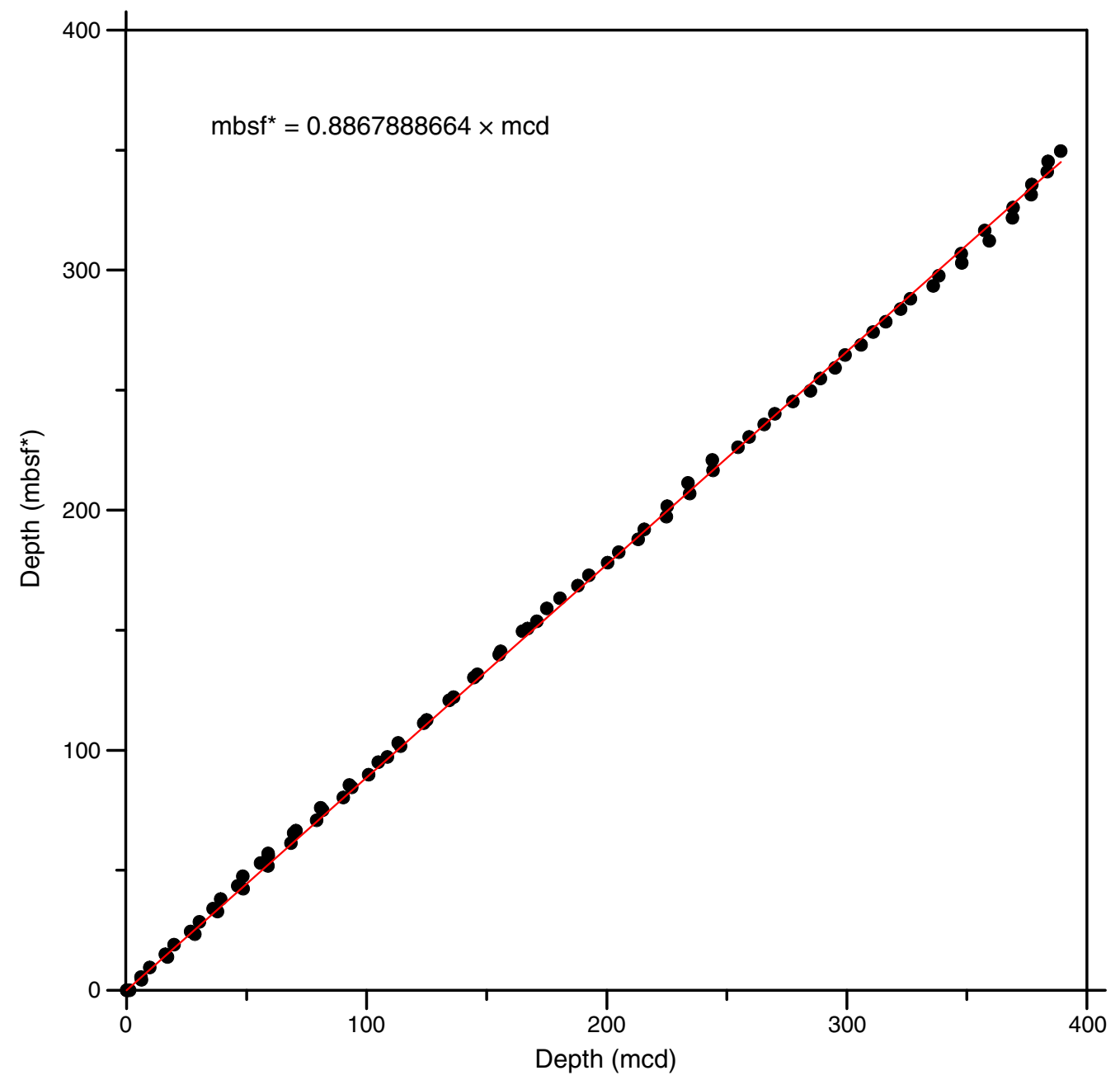


Table T1. Coring summary, Site U1389. (Continued on next three pages.)

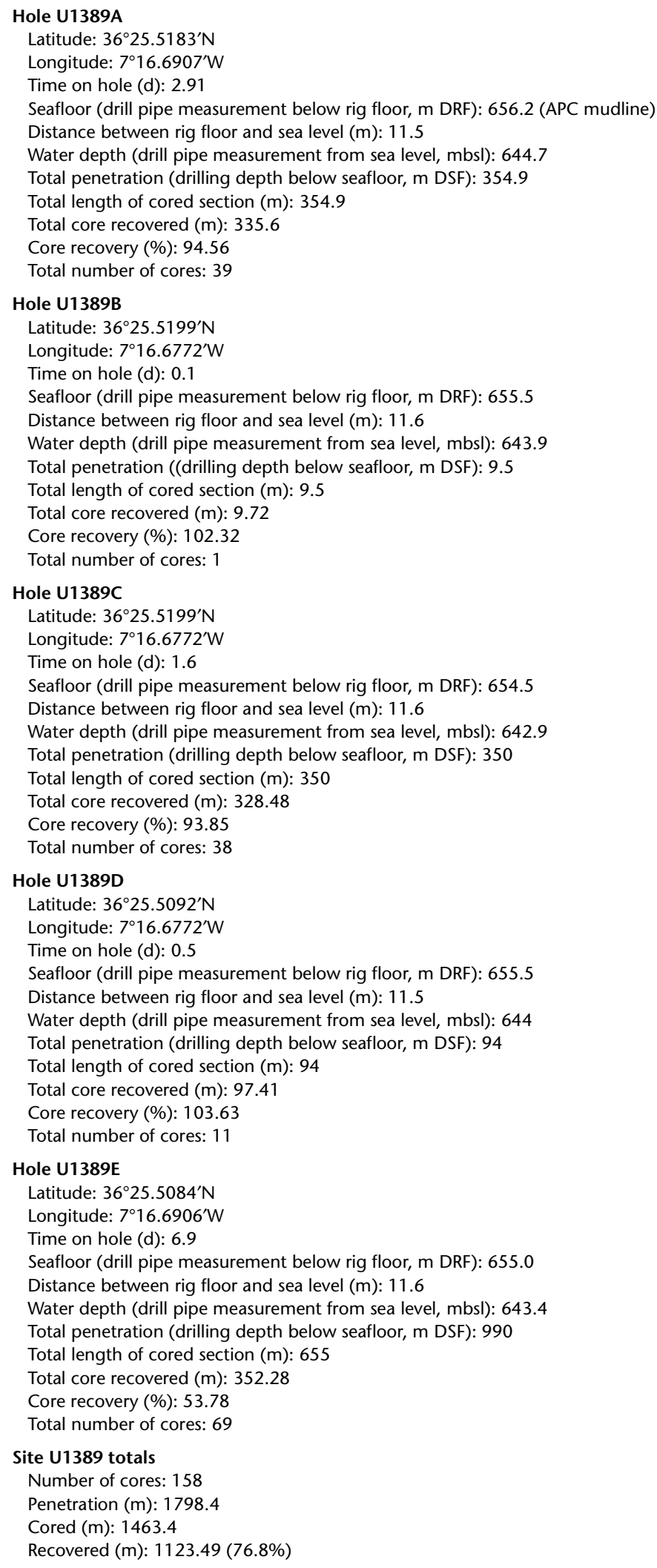


Table T1 (continued). (Continued on next page.)

\begin{tabular}{|c|c|c|c|c|c|c|c|c|c|c|}
\hline \multirow[b]{2}{*}{ Core } & \multirow[b]{2}{*}{ Date } & \multirow[b]{2}{*}{$\begin{array}{l}\text { Time } \\
\text { (h) }\end{array}$} & \multicolumn{2}{|c|}{ Depth DSF (m) } & \multirow[b]{2}{*}{$\begin{array}{c}\text { Interval } \\
\text { advanced }(\mathrm{m})\end{array}$} & \multicolumn{2}{|c|}{ Depth CSF (m) } & \multirow[b]{2}{*}{$\begin{array}{l}\text { Length of core } \\
\text { recovered }(\mathrm{m})\end{array}$} & \multirow[b]{2}{*}{$\begin{array}{c}\text { Curated } \\
\text { length }(m)\end{array}$} & \multirow[b]{2}{*}{$\begin{array}{l}\text { Recovery } \\
(\%)\end{array}$} \\
\hline & & & $\begin{array}{l}\text { Top of cored } \\
\text { interval }\end{array}$ & $\begin{array}{l}\text { Bottom of } \\
\text { cored interval }\end{array}$ & & $\begin{array}{c}\text { Top of } \\
\text { recovered core }\end{array}$ & $\begin{array}{l}\text { Bottom of } \\
\text { recovered core }\end{array}$ & & & \\
\hline 339-U138 & & & & & & & & & & \\
\hline $1 \mathrm{H}$ & $22 \operatorname{Dec} 2011$ & 0250 & 0.0 & 4.3 & 4.3 & 0.0 & 4.30 & 4.30 & 4.30 & 100 \\
\hline $2 \mathrm{H}$ & 22 Dec 2011 & 0350 & 4.3 & 13.8 & 9.5 & 4.3 & 14.18 & 9.88 & 9.88 & 104 \\
\hline $3 \mathrm{H}$ & $22 \operatorname{Dec} 2011$ & 0430 & 13.8 & 23.3 & 9.5 & 13.8 & 23.71 & 9.96 & 9.91 & 105 \\
\hline $4 \mathrm{H}$ & 22 Dec 2011 & 0510 & 23.3 & 32.8 & 9.5 & 23.3 & 33.39 & 10.01 & 10.09 & 105 \\
\hline $5 \mathrm{H}$ & 22 Dec 2011 & 0610 & 32.8 & 42.3 & 9.5 & 32.8 & 43.04 & 10.06 & 10.24 & 106 \\
\hline $6 \mathrm{H}$ & 22 Dec 2011 & 0645 & 42.3 & 51.8 & 9.5 & 42.3 & 52.43 & 10.04 & 10.13 & 106 \\
\hline $7 \mathrm{H}$ & 22 Dec 2011 & 0725 & 51.8 & 61.3 & 9.5 & 51.8 & 61.54 & 9.73 & 9.74 & 102 \\
\hline $8 \mathrm{H}$ & 22 Dec 2011 & 0800 & 61.3 & 70.8 & 9.5 & 61.3 & 71.48 & 10.08 & 10.18 & 106 \\
\hline $9 \mathrm{H}$ & 22 Dec 2011 & 0845 & 70.8 & 80.3 & 9.5 & 70.8 & 81.00 & 10.20 & 10.20 & 107 \\
\hline $10 \mathrm{H}$ & $22 \operatorname{Dec} 2011$ & 0935 & 80.3 & 89.8 & 9.5 & 80.3 & 90.55 & 10.25 & 10.25 & 108 \\
\hline $11 \mathrm{H}$ & 22 Dec 2011 & 1015 & 89.8 & 97.2 & 7.4 & 89.8 & 97.31 & 7.48 & 7.51 & 101 \\
\hline $12 \mathrm{X}$ & 22 Dec 2011 & 1150 & 97.2 & 101.7 & 4.5 & 97.2 & 102.55 & 5.34 & 5.35 & 119 \\
\hline $13 x$ & 22 Dec 2011 & 1220 & 101.7 & 111.3 & 9.6 & 101.7 & 109.99 & 8.29 & 8.29 & 86 \\
\hline $14 \mathrm{X}$ & 22 Dec 2011 & 1255 & 111.3 & 120.8 & 9.5 & 111.3 & 120.95 & 9.65 & 9.65 & 102 \\
\hline $15 x$ & $22 \operatorname{Dec} 2011$ & 1325 & 120.8 & 130.3 & 9.5 & 120.8 & 129.55 & 8.75 & 8.75 & 92 \\
\hline $16 X$ & 22 Dec 2011 & 1350 & 130.3 & 139.9 & 9.6 & 130.3 & 139.78 & 9.48 & 9.48 & 99 \\
\hline $17 X$ & 22 Dec 2011 & 1415 & 139.9 & 149.5 & 9.6 & 139.9 & 148.37 & 8.47 & 8.47 & 88 \\
\hline $18 \mathrm{X}$ & 22 Dec 2011 & 1445 & 149.5 & 159.0 & 9.5 & 149.5 & 158.31 & 8.81 & 8.81 & 93 \\
\hline $19 \mathrm{X}$ & 22 Dec 2011 & 1530 & 159.0 & 168.5 & 9.5 & 159.0 & 168.42 & 9.42 & 9.42 & 99 \\
\hline $20 x$ & 22 Dec 2011 & 1555 & 168.5 & 178.1 & 9.6 & 168.5 & 177.69 & 9.19 & 9.19 & 96 \\
\hline $21 x$ & 22 Dec 2011 & 1655 & 178.1 & 187.8 & 9.7 & 178.1 & 187.74 & 9.64 & 9.64 & 99 \\
\hline $22 x$ & 22 Dec 2011 & 1750 & 187.8 & 197.3 & 9.5 & 187.8 & 197.52 & 9.72 & 9.72 & 102 \\
\hline $23 x$ & 22 Dec 2011 & 1845 & 197.3 & 206.9 & 9.6 & 197.3 & 206.93 & 9.63 & 9.63 & 100 \\
\hline $24 X$ & $22 \operatorname{Dec} 2011$ & 1940 & 206.9 & 216.6 & 9.7 & 206.9 & 216.63 & 9.73 & 9.73 & 100 \\
\hline $25 x$ & 22 Dec 2011 & 2030 & 216.6 & 226.2 & 9.6 & 216.6 & 226.49 & 9.89 & 9.89 & 103 \\
\hline $26 x$ & 22 Dec 2011 & 2110 & 226.2 & 235.7 & 9.5 & 226.2 & 234.71 & 8.51 & 8.51 & 90 \\
\hline $27 X$ & 22 Dec 2011 & 2210 & 235.7 & 245.3 & 9.6 & 235.7 & 245.16 & 9.46 & 9.46 & 99 \\
\hline $28 \mathrm{X}$ & 22 Dec 2011 & 2300 & 245.3 & 254.9 & 9.6 & 245.3 & 255.27 & 9.97 & 9.97 & 104 \\
\hline $29 x$ & 22 Dec 2011 & 0000 & 254.9 & 264.6 & 9.7 & 254.9 & 264.61 & 9.71 & 9.71 & 100 \\
\hline $30 x$ & 23 Dec 2011 & 0115 & 264.6 & 274.2 & 9.6 & 264.6 & 274.35 & 9.75 & 9.75 & 102 \\
\hline $31 x$ & 23 Dec 2011 & 0230 & 274.2 & 283.8 & 9.6 & 274.2 & 283.61 & 9.41 & 9.41 & 98 \\
\hline $32 x$ & 23 Dec 2011 & 0330 & 283.8 & 293.4 & 9.6 & 283.8 & 293.23 & 9.43 & 9.43 & 98 \\
\hline $33 x$ & 23 Dec 2011 & 0450 & 293.4 & 303.0 & 9.6 & 293.4 & 302.36 & 8.96 & 8.96 & 93 \\
\hline $34 \mathrm{X}$ & 23 Dec 2011 & 0600 & 303.0 & 312.2 & 9.2 & 303.0 & 312.56 & 9.56 & 9.56 & 104 \\
\hline $35 x$ & 23 Dec 2011 & 0700 & 312.2 & 321.8 & 9.6 & 312.2 & 320.69 & 8.49 & 8.49 & 88 \\
\hline $36 x$ & 23 Dec 2011 & 0750 & 321.8 & 331.4 & 9.6 & 321.8 & 324.52 & 2.72 & 2.72 & 28 \\
\hline $37 X$ & 23 Dec 2011 & 0900 & 331.4 & 341.0 & 9.6 & 331.4 & 336.48 & 5.08 & 5.08 & 53 \\
\hline $38 \mathrm{x}$ & 23 Dec 2011 & 1230 & 341.0 & 349.6 & 8.6 & 341.0 & 346.25 & 5.25 & 5.25 & 61 \\
\hline $39 x$ & 23 Dec 2011 & 1410 & 349.6 & 354.9 & 5.3 & 349.6 & 350.90 & 1.30 & 1.30 & 25 \\
\hline & & & & vanced total: & 354.9 & & & & & \\
\hline & & & Total in & terval cored: & 335.6 & & & & & \\
\hline 339-U138 & & & & & & & & & & \\
\hline $1 \mathrm{H}$ & 24 Dec 2011 & 1950 & 0.0 & 9.5 & 9.5 & 0.0 & 9.72 & 9.72 & 9.72 & 102 \\
\hline & & & & vanced total: & 9.5 & & & & & \\
\hline & & & Total in & terval cored: & 9.72 & & & & & \\
\hline 339-U138 & & & & & & & & & & \\
\hline $1 \mathrm{H}$ & $24 \operatorname{Dec} 2011$ & 2100 & 0.0 & 9.5 & 9.5 & 0.0 & 9.74 & 9.74 & 9.74 & 103 \\
\hline $2 \mathrm{H}$ & 24 Dec 2011 & 2210 & 9.5 & 19.0 & 9.5 & 9.5 & 19.54 & 10.04 & 10.04 & 106 \\
\hline $3 \mathrm{H}$ & $24 \operatorname{Dec} 2011$ & 2240 & 19.0 & 28.5 & 9.5 & 19.0 & 29.23 & 10.20 & 10.23 & 107 \\
\hline $4 \mathrm{H}$ & 24 Dec 2011 & 2310 & 28.5 & 38.0 & 9.5 & 28.5 & 38.00 & 9.44 & 9.50 & 99 \\
\hline $5 \mathrm{H}$ & 24 Dec 2011 & 2350 & 38.0 & 47.5 & 9.5 & 38.0 & 48.02 & 9.95 & 10.02 & 105 \\
\hline $6 \mathrm{H}$ & 25 Dec 2011 & 0040 & 47.5 & 57.0 & 9.5 & 47.5 & 57.46 & 9.71 & 9.96 & 102 \\
\hline $7 \mathrm{H}$ & 25 Dec 2011 & 0115 & 57.0 & 66.5 & 9.5 & 57.0 & 66.69 & 9.65 & 9.69 & 102 \\
\hline $8 \mathrm{H}$ & 25 Dec 2011 & 0205 & 66.5 & 76.0 & 9.5 & 66.5 & 75.62 & 8.99 & 9.12 & 95 \\
\hline $9 \mathrm{H}$ & 25 Dec 2011 & 0245 & 76.0 & 85.5 & 9.5 & 76.0 & 86.14 & 10.00 & 10.14 & 105 \\
\hline $10 \mathrm{H}$ & 25 Dec 2011 & 0340 & 85.5 & 95.0 & 9.5 & 85.5 & 96.21 & 10.44 & 10.71 & 110 \\
\hline $11 x$ & 25 Dec 2011 & 0500 & 95.0 & 103.0 & 8.0 & 95.0 & 101.67 & 6.67 & 6.67 & 83 \\
\hline $12 \mathrm{X}$ & 25 Dec 2011 & 0540 & 103.0 & 112.6 & 9.6 & 103.0 & 111.64 & 8.64 & 8.64 & 90 \\
\hline $13 x$ & 25 Dec 2011 & 0640 & 112.6 & 122.1 & 9.5 & 112.6 & 122.26 & 9.66 & 9.66 & 102 \\
\hline $14 X$ & 25 Dec 2011 & 0730 & 122.1 & 131.6 & 9.5 & 122.1 & 131.66 & 9.56 & 9.56 & 101 \\
\hline $15 x$ & 25 Dec 2011 & 0810 & 131.6 & 141.2 & 9.6 & 131.6 & 141.01 & 9.41 & 9.41 & 98 \\
\hline $16 \mathrm{X}$ & 25 Dec 2011 & 0855 & 141.2 & 150.7 & 9.5 & 141.2 & 148.48 & 7.28 & 7.28 & 77 \\
\hline $17 X$ & 25 Dec 2011 & 0930 & 150.7 & 153.7 & 3.0 & 150.7 & 155.37 & 4.67 & 4.67 & 156 \\
\hline $18 \mathrm{X}$ & 25 Dec 2011 & 1010 & 153.7 & 163.3 & 9.6 & 153.7 & 163.20 & 9.50 & 9.50 & 99 \\
\hline $19 x$ & 25 Dec 2011 & 1040 & 163.3 & 172.9 & 9.6 & 163.3 & 172.93 & 9.63 & 9.63 & 100 \\
\hline $20 x$ & 25 Dec 2011 & 1120 & 172.9 & 182.5 & 9.6 & 172.9 & 182.71 & 9.81 & 9.81 & 102 \\
\hline
\end{tabular}


Table T1 (continued). (Continued on next page.)

\begin{tabular}{|c|c|c|c|c|c|c|c|c|c|c|}
\hline \multirow[b]{2}{*}{ Core } & \multirow[b]{2}{*}{ Date } & \multirow[b]{2}{*}{$\begin{array}{l}\text { Time } \\
(\mathrm{h})\end{array}$} & \multicolumn{2}{|c|}{ Depth DSF (m) } & \multirow[b]{2}{*}{$\begin{array}{c}\text { Interval } \\
\text { advanced (m) }\end{array}$} & \multicolumn{2}{|c|}{ Depth CSF (m) } & \multirow[b]{2}{*}{$\begin{array}{l}\text { Length of core } \\
\text { recovered }(\mathrm{m})\end{array}$} & \multirow[b]{2}{*}{$\begin{array}{l}\text { Curated } \\
\text { length }(\mathrm{m})\end{array}$} & \multirow[b]{2}{*}{$\begin{array}{c}\text { Recovery } \\
\text { (\%) }\end{array}$} \\
\hline & & & $\begin{array}{l}\text { Top of cored } \\
\text { interval }\end{array}$ & $\begin{array}{l}\text { Bottom of } \\
\text { cored interval }\end{array}$ & & $\begin{array}{l}\text { Top of } \\
\text { recovered core }\end{array}$ & $\begin{array}{l}\text { Bottom of } \\
\text { recovered core }\end{array}$ & & & \\
\hline $21 X$ & 25 Dec 2011 & 1205 & 182.5 & 192.0 & 9.5 & 182.5 & 192.21 & 9.71 & 9.71 & 102 \\
\hline $22 X$ & 25 Dec 2011 & 1315 & 192.0 & 201.7 & 9.7 & 192.0 & 201.63 & 9.63 & 9.63 & 99 \\
\hline $23 x$ & 25 Dec 2011 & 1530 & 201.7 & 211.3 & 9.6 & 201.7 & 211.52 & 9.82 & 9.82 & 102 \\
\hline $24 X$ & 25 Dec 2011 & 1630 & 211.3 & 220.9 & 9.6 & 211.3 & 221.12 & 9.82 & 9.82 & 102 \\
\hline $25 X$ & 25 Dec 2011 & 1750 & 220.9 & 230.5 & 9.6 & 220.9 & 228.46 & 7.56 & 7.56 & 79 \\
\hline $26 x$ & 25 Dec 2011 & 1840 & 230.5 & 240.1 & 9.6 & 230.5 & 239.14 & 8.64 & 8.64 & 90 \\
\hline $27 X$ & 25 Dec 2011 & 1940 & 240.1 & 249.7 & 9.6 & 240.1 & 249.78 & 9.68 & 9.68 & 101 \\
\hline $28 \mathrm{X}$ & 25 Dec 2011 & 2050 & 249.7 & 259.3 & 9.6 & 249.7 & 259.33 & 9.63 & 9.63 & 100 \\
\hline $29 X$ & 25 Dec 2011 & 2200 & 259.3 & 268.9 & 9.6 & 259.3 & 269.12 & 9.82 & 9.82 & 102 \\
\hline $30 x$ & 26 Dec 2011 & 2325 & 268.9 & 278.5 & 9.6 & 268.9 & 278.75 & 9.85 & 9.85 & 103 \\
\hline $31 x$ & 26 Dec 2011 & 0030 & 278.5 & 288.1 & 9.6 & 278.5 & 288.24 & 9.74 & 9.74 & 101 \\
\hline $32 \mathrm{X}$ & 26 Dec 2011 & 0150 & 288.1 & 297.7 & 9.6 & 288.1 & 297.77 & 9.67 & 9.67 & 101 \\
\hline $33 x$ & 26 Dec 2011 & 0240 & 297.7 & 306.9 & 9.2 & 297.7 & 306.74 & 9.04 & 9.04 & 98 \\
\hline $34 X$ & 26 Dec 2011 & 0340 & 306.9 & 316.5 & 9.6 & 306.9 & 316.11 & 9.21 & 9.21 & 96 \\
\hline $35 x$ & 26 Dec 2011 & 0435 & 316.5 & 326.1 & 9.6 & 316.5 & 323.29 & 6.79 & 6.79 & 71 \\
\hline $36 \mathrm{X}$ & 26 Dec 2011 & 0535 & 326.1 & 335.7 & 9.6 & 326.1 & 328.47 & 2.37 & 2.37 & 25 \\
\hline $37 x$ & 26 Dec 2011 & 0645 & 335.7 & 345.3 & 9.6 & 335.7 & 338.50 & 2.80 & 2.80 & 29 \\
\hline $38 x$ & 26 Dec 2011 & 0800 & 345.3 & 350.0 & 4.7 & 345.3 & 347.01 & 1.71 & 1.71 & 36 \\
\hline & & & & vanced total: & 345.3 & & & & & \\
\hline & & & Total in & terval cored: & 328.48 & & & & & \\
\hline 339-U138 & & & & & & & & & & \\
\hline $1 \mathrm{H}$ & 26 Dec 2011 & 1125 & 0.0 & 5.5 & 5.5 & 0.0 & 5.50 & 5.50 & 5.50 & 100 \\
\hline $2 \mathrm{H}$ & 26 Dec 2011 & 1215 & 5.5 & 15.0 & 9.5 & 5.5 & 15.20 & 9.70 & 9.70 & 102 \\
\hline $3 \mathrm{H}$ & 26 Dec 2011 & 1305 & 15.0 & 24.5 & 9.5 & 15.0 & 25.18 & 10.12 & 10.18 & 107 \\
\hline $4 \mathrm{H}$ & 26 Dec 2011 & 1345 & 24.5 & 34.0 & 9.5 & 24.5 & 34.49 & 9.90 & 9.99 & 104 \\
\hline $5 \mathrm{H}$ & 26 Dec 2011 & 1420 & 34.0 & 43.5 & 9.5 & 34.0 & 44.00 & 9.89 & 10.00 & 104 \\
\hline $6 \mathrm{H}$ & 26 Dec 2011 & 1500 & 43.5 & 53.0 & 9.5 & 43.5 & 53.76 & 10.22 & 10.26 & 108 \\
\hline $7 \mathrm{H}$ & 26 Dec 2011 & 1540 & 53.0 & 56.0 & 3.0 & 53.0 & 56.35 & 3.33 & 3.35 & 111 \\
\hline $8 \mathrm{H}$ & 26 Dec 2011 & 1610 & 56.0 & 65.5 & 9.5 & 56.0 & 65.97 & 9.85 & 9.97 & 104 \\
\hline $9 \mathrm{H}$ & 26 Dec 2011 & 1700 & 65.5 & 75.0 & 9.5 & 65.5 & 75.00 & 9.45 & 9.50 & 99 \\
\hline $10 \mathrm{H}$ & 26 Dec 2011 & 1740 & 75.0 & 84.5 & 9.5 & 75.0 & 84.54 & 9.49 & 9.54 & 100 \\
\hline $11 \mathrm{H}$ & 26 Dec 2011 & 1825 & 84.5 & 94.0 & 9.5 & 84.5 & 94.52 & 9.96 & 10.02 & 105 \\
\hline & & & & vanced total: & 94 & & & & & \\
\hline & & & Total in & terval cored: & 97.41 & & & & & \\
\hline 339-U138 & & & & & & & & & & \\
\hline $1 \mathrm{~W}$ & 27 Dec 2011 & 1825 & & & ${ }^{\star * \star * *}$ Drilled from & $\mathrm{m} 0$ to $335.0 \mathrm{~m} \mathrm{D}$ & DSF without cor & ring & & \\
\hline $2 \mathrm{R}$ & 27 Dec 2011 & 1930 & 335.0 & 339.5 & 4.5 & 335.0 & 337.39 & 2.39 & 2.39 & 53 \\
\hline $3 \mathrm{R}$ & 27 Dec 2011 & 2040 & 339.5 & 348.8 & 9.3 & 339.5 & 344.37 & 4.87 & 4.87 & 52 \\
\hline $4 \mathrm{R}$ & 27 Dec 2011 & 2135 & 348.8 & 358.4 & 9.6 & 348.8 & 352.69 & 3.89 & 3.89 & 41 \\
\hline $5 R$ & 27 Dec 2011 & 2245 & 358.4 & 368.0 & 9.6 & 358.4 & 362.59 & 4.19 & 4.19 & 44 \\
\hline $6 \mathrm{R}$ & 28 Dec 2011 & 2340 & 368.0 & 377.5 & 9.5 & 368.0 & 369.54 & 1.54 & 1.54 & 16 \\
\hline $7 \mathrm{R}$ & 28 Dec 2011 & 0045 & 377.5 & 387.1 & 9.6 & 377.5 & 377.66 & 0.16 & 0.16 & 2 \\
\hline $8 \mathrm{R}$ & 28 Dec 2011 & 0210 & 387.1 & 396.7 & 9.6 & 387.1 & 391.60 & 4.50 & 4.50 & 47 \\
\hline $9 \mathrm{R}$ & 28 Dec 2011 & 0345 & 396.7 & 406.3 & 9.6 & 396.7 & 402.70 & 6.00 & 6.00 & 63 \\
\hline $10 \mathrm{R}$ & 28 Dec 2011 & 0445 & 406.3 & 415.9 & 9.6 & 406.3 & 408.17 & 1.87 & 1.87 & 19 \\
\hline $11 \mathrm{R}$ & 28 Dec 2011 & 0610 & 415.9 & 425.5 & 9.6 & 415.9 & 421.80 & 5.90 & 5.90 & 61 \\
\hline $12 \mathrm{R}$ & 28 Dec 2011 & 0810 & 425.5 & 435.1 & 9.6 & 425.5 & 433.73 & 8.23 & 8.23 & 86 \\
\hline $13 \mathrm{R}$ & 28 Dec 2011 & 0925 & 435.1 & 444.7 & 9.6 & 435.1 & 443.05 & 7.95 & 7.95 & 83 \\
\hline $14 \mathrm{R}$ & 28 Dec 2011 & 1030 & 444.7 & 454.3 & 9.6 & 444.7 & 450.25 & 5.55 & 5.55 & 58 \\
\hline $15 \mathrm{R}$ & 28 Dec 2011 & 1155 & 454.3 & 463.8 & 9.5 & 454.3 & 459.12 & 4.82 & 4.82 & 51 \\
\hline $16 \mathrm{R}$ & 28 Dec 2011 & 1245 & 463.8 & 473.3 & 9.5 & 463.8 & 465.11 & 1.31 & 1.31 & 14 \\
\hline $17 \mathrm{R}$ & 28 Dec 2011 & 1355 & 473.3 & 482.8 & 9.5 & 473.3 & 478.86 & 5.56 & 5.56 & 59 \\
\hline $18 \mathrm{R}$ & 28 Dec 2011 & 1450 & 482.8 & 492.3 & 9.5 & 482.8 & 485.01 & 2.21 & 2.21 & 23 \\
\hline $19 R$ & 28 Dec 2011 & 1600 & 492.3 & 501.8 & 9.5 & 492.3 & 496.42 & 4.12 & 4.12 & 43 \\
\hline $20 \mathrm{R}$ & 28 Dec 2011 & 1815 & 501.8 & 511.3 & 9.5 & 501.8 & 510.09 & 8.29 & 8.29 & 87 \\
\hline $21 \mathrm{R}$ & 28 Dec 2011 & 1930 & 511.3 & 520.8 & 9.5 & 511.3 & 515.65 & 4.35 & 4.35 & 46 \\
\hline $22 \mathrm{R}$ & 28 Dec 2011 & 2045 & 520.8 & 530.3 & 9.5 & 520.8 & 526.25 & 5.45 & 5.45 & 57 \\
\hline $23 R$ & 28 Dec 2011 & 2205 & 530.3 & 540.1 & 9.8 & 530.3 & 535.75 & 5.45 & 5.45 & 56 \\
\hline $24 \mathrm{R}$ & 28 Dec 2011 & 2345 & 540.1 & 549.8 & 9.7 & 540.1 & 548.23 & 8.13 & 8.13 & 84 \\
\hline $25 \mathrm{R}$ & 29 Dec 2011 & 0140 & 549.8 & 559.4 & 9.6 & 549.8 & 558.12 & 8.32 & 8.32 & 87 \\
\hline $26 \mathrm{R}$ & 29 Dec 2011 & 0305 & 559.4 & 569.0 & 9.6 & 559.4 & 567.36 & 7.96 & 7.96 & 83 \\
\hline $27 \mathrm{R}$ & 29 Dec 2011 & 0425 & 569.0 & 578.6 & 9.6 & 569.0 & 573.79 & 4.79 & 4.79 & 50 \\
\hline $28 \mathrm{R}$ & 29 Dec 2011 & 0545 & 578.6 & 588.2 & 9.6 & 578.6 & 586.78 & 8.18 & 8.18 & 85 \\
\hline $29 \mathrm{R}$ & 29 Dec 2011 & 0715 & 588.2 & 597.8 & 9.6 & 588.2 & 595.49 & 7.29 & 7.29 & 76 \\
\hline $30 \mathrm{R}$ & 29 Dec 2011 & 0855 & 597.8 & 607.4 & 9.6 & 597.8 & 607.70 & 9.90 & 9.90 & 103 \\
\hline $31 \mathrm{R}$ & 29 Dec 2011 & 1035 & 607.4 & 617.0 & 9.6 & 607.4 & 617.28 & 9.88 & 9.88 & 103 \\
\hline $32 \mathrm{R}$ & 29 Dec 2011 & 1210 & 617.0 & 626.6 & 9.6 & 617.0 & 626.28 & 9.28 & 9.28 & 97 \\
\hline
\end{tabular}


Table T1 (continued).

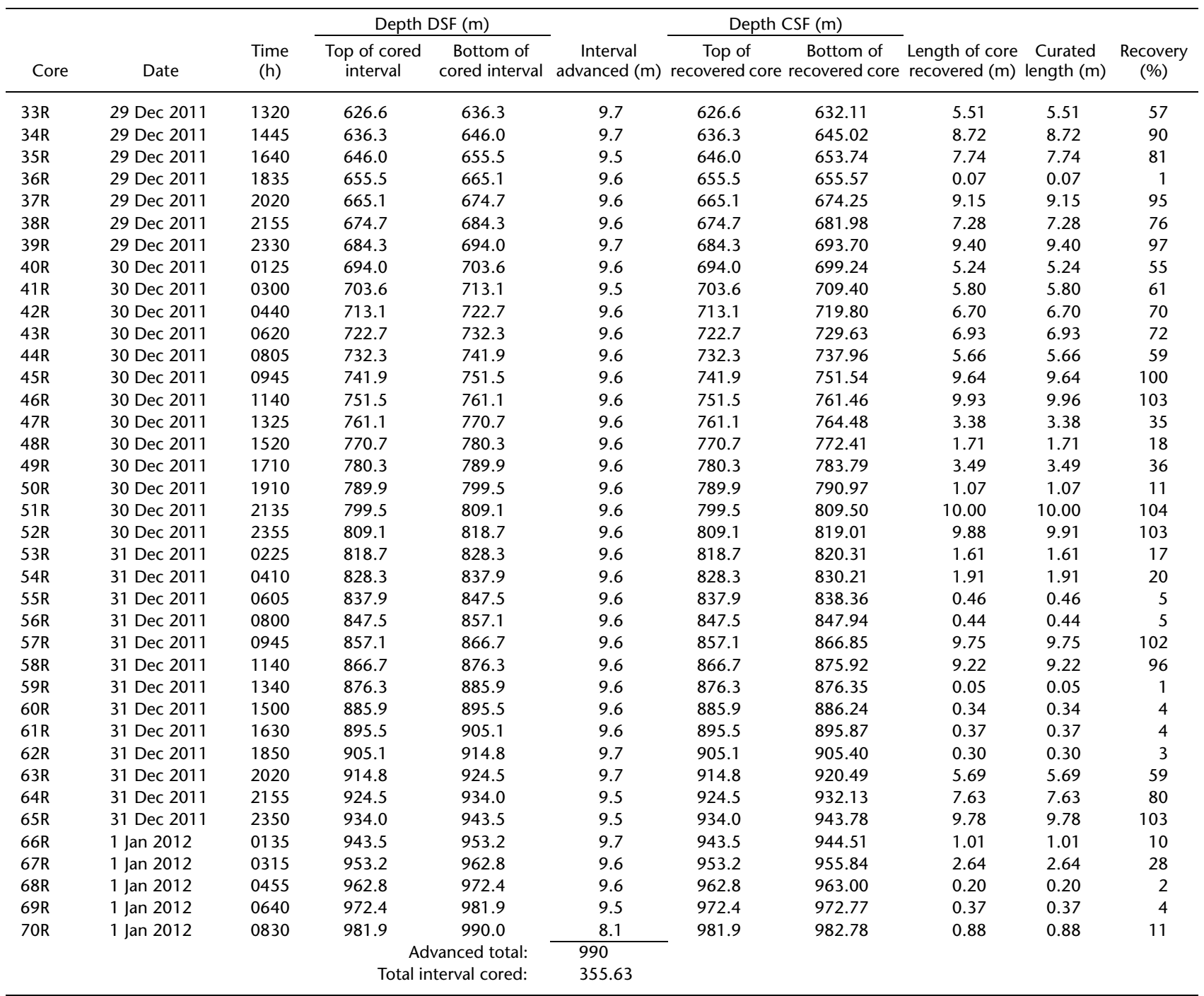

$\mathrm{DRF}=$ drilling depth below rig floor, $\mathrm{DSF}=$ drilling depth below seafloor, $\mathrm{CSF}=$ core depth below seafloor. $\mathrm{H}=$ advanced piston coring system, $\mathrm{X}$ = extended core barrel system, $\mathrm{R}=$ rotary core barrel system, $\mathrm{W}=$ washed interval. Time is Universal Time Coordinated.

Table T2. Sediment textures and compositions determined by smear slide, Site U1389.

\begin{tabular}{lcccccccc}
\hline & \multicolumn{3}{c}{ Texture (\%) } & & \multicolumn{4}{c}{ Composition (\%) } \\
\cline { 2 - 3 } \cline { 6 - 8 } Lith. unit & Sand & Silt & Clay & & Siliciclastic & $\begin{array}{c}\text { Detrital } \\
\text { carbonate }\end{array}$ & $\begin{array}{c}\text { Biogenic } \\
\text { carbonate }\end{array}$ & $\begin{array}{c}\text { Biogenic } \\
\text { silica }\end{array}$ \\
\hline I & 24 & 32 & 45 & & 44 & 30 & 25 & 0 \\
IA & 31 & 30 & 39 & & 38 & 34 & 28 & 1 \\
IB & 20 & 33 & 47 & & 45 & 31 & 24 & 0 \\
IC & 17 & 31 & 51 & & 56 & 27 & 22 & 0 \\
ID & 24 & 29 & 48 & & 50 & 27 & 24 & 0 \\
IE & 19 & 31 & 50 & & 50 & 24 & 23 & 0 \\
\hline
\end{tabular}


Table T3. Lithology and number of beds based on smear slide data, Site U1389.

\begin{tabular}{lccccc}
\hline Lith. unit & $\begin{array}{c}\text { Silty sandy } \\
\text { beds }\end{array}$ & $\begin{array}{c}\text { Sandy mud } \\
\text { beds }\end{array}$ & $\begin{array}{c}\text { Silty mud } \\
\text { beds }\end{array}$ & $\begin{array}{c}\text { Sandy contourite } \\
\text { beds }\end{array}$ & $\begin{array}{c}\text { Sandy sharp base/ } \\
\text { normal grading beds }\end{array}$ \\
\hline IA & 106 & 166 & 411 & 177 & 51 \\
IB & 9 & 15 & 15 & 9 & 10 \\
IC & 3 & 37 & 40 & 19 & 17 \\
ID & 7 & 74 & 64 & 50 & 23 \\
IE & 0 & 22 & 43 & 22 & 0 \\
\hline
\end{tabular}

Table T4. Summary of subunit lithologic characteristics based on core descriptions, Site U1389.

\begin{tabular}{lcccc}
\hline Lith. unit & $\begin{array}{c}\text { Silty sand } \\
(\%)\end{array}$ & $\begin{array}{c}\text { Sandy mud } \\
(\%)\end{array}$ & $\begin{array}{c}\text { Silty mud } \\
(\%)\end{array}$ & $\begin{array}{c}\text { Calcareous mud } \\
(\%)\end{array}$ \\
\hline I & 4 & 11 & 24 & 61 \\
IA & 6 & 7 & 24 & 63 \\
IB & 3 & 4 & 11 & 82 \\
IC & 0 & 13 & 18 & 69 \\
ID & 2 & 16 & 19 & 63 \\
IE & 0 & 16 & 34 & 50 \\
\hline
\end{tabular}


Table T5. Lithologic units and average XRD peak intensities of minerals from bulk sediment, Site U1389.

\begin{tabular}{|c|c|c|c|c|c|c|c|c|c|c|c|c|c|c|}
\hline Lith. unit & $\begin{array}{c}\text { Total } \\
\text { intensity } \\
\text { (counts) }\end{array}$ & $\begin{array}{l}\text { Quartz } \\
\text { (counts) }\end{array}$ & $\begin{array}{c}\text { Calcite } \\
\text { (counts) }\end{array}$ & $\begin{array}{l}\text { K-feldspar } \\
\text { (counts) }\end{array}$ & $\begin{array}{l}\text { Plagioclase } \\
\text { (counts) }\end{array}$ & $\begin{array}{l}\text { Dolomite } \\
\text { (counts) }\end{array}$ & $\begin{array}{l}\text { Chlorite } \\
\text { (counts) }\end{array}$ & $\begin{array}{l}\text { Kaolinite } \\
\text { (counts) }\end{array}$ & $\begin{array}{c}\text { Illite } \\
\text { (counts) }\end{array}$ & $\begin{array}{l}\text { Smectite } \\
\text { (counts) }\end{array}$ & $\begin{array}{l}\text { Hornblende } \\
\text { (counts) }\end{array}$ & $\begin{array}{c}\text { Augite } \\
\text { (counts) }\end{array}$ & $\begin{array}{l}\text { Pyrite } \\
\text { (counts) }\end{array}$ & $\begin{array}{c}\text { Aragonite } \\
\text { (counts) }\end{array}$ \\
\hline IA & 60,186 & 30,018 & 14,921 & 1,757 & 1,890 & 3,557 & 901 & 2,021 & 4,286 & 510 & 225 & 808 & 352 & 704 \\
\hline IB & 49,646 & 23,883 & 13,703 & 509 & 1,448 & 2,325 & 1,055 & 2,111 & 3,688 & 577 & 177 & 505 & 575 & NA \\
\hline ID & 60,768 & 32,147 & 14,097 & 974 & 1,909 & 3,256 & 1,108 & 2,616 & 3,669 & 609 & 96 & 467 & 607 & 662 \\
\hline IE & 59,702 & 29,064 & 16,913 & 857 & 1,540 & 2,896 & 1,130 & 2,427 & 4,078 & 609 & 87 & 352 & 651 & 651 \\
\hline
\end{tabular}

$\mathrm{NA}=$ no peak detected

Table T6. XRD peak intensities of minerals from bulk sediment, Site U1389. (Continued on next two pages.)

\begin{tabular}{|c|c|c|c|c|c|c|c|c|c|c|c|c|c|c|c|}
\hline $\begin{array}{l}\text { Hole, core, section, } \\
\text { interval }(\mathrm{cm})\end{array}$ & $\begin{array}{l}\text { Depth } \\
\text { (mbsf) }\end{array}$ & $\begin{array}{c}\text { Total } \\
\text { intensity } \\
\text { (counts) }\end{array}$ & $\begin{array}{l}\text { Quartz } \\
\text { (counts) }\end{array}$ & $\begin{array}{l}\text { Calcite } \\
\text { (counts) }\end{array}$ & $\begin{array}{l}\text { K-feldspar } \\
\text { (counts) }\end{array}$ & $\begin{array}{l}\text { Plagioclase } \\
\text { (counts) }\end{array}$ & $\begin{array}{l}\text { Dolomite } \\
\text { (counts) }\end{array}$ & $\begin{array}{l}\text { Chlorite } \\
\text { (counts) }\end{array}$ & $\begin{array}{l}\text { Kaolinite } \\
\text { (counts) }\end{array}$ & $\begin{array}{c}\text { Illite } \\
\text { (counts) }\end{array}$ & $\begin{array}{l}\text { Smectite } \\
\text { (counts) }\end{array}$ & $\begin{array}{l}\text { Hornblende } \\
\text { (counts) }\end{array}$ & $\begin{array}{l}\text { Augite } \\
\text { (counts) }\end{array}$ & $\begin{array}{l}\text { Pyrite } \\
\text { (counts) }\end{array}$ & $\begin{array}{c}\text { Aragonite } \\
\text { (counts) }\end{array}$ \\
\hline \multicolumn{16}{|l|}{$339-$} \\
\hline U1389A-1H-3, 96-97 & 3.96 & 47,268 & 25,588 & 13,276 & 525 & 954 & 1,384 & 679 & 1,685 & 2,229 & 414 & NA & NA & NA & 534 \\
\hline U1389A-2H-6, 140-141 & 13.20 & 57,230 & 31,331 & 13,672 & 717 & 1,422 & 3,009 & 775 & 1,552 & 3,847 & 354 & 551 & NA & NA & NA \\
\hline U1389A-3H-6, 137-138 & 22.61 & 96,528 & 52,437 & 17,439 & 1,611 & 3,319 & 9,862 & 998 & 2,175 & 7,456 & 328 & 903 & NA & NA & NA \\
\hline U1389A-4H-5, 140-141 & 30.74 & 56,065 & 30,079 & 12,640 & 1,925 & 1,248 & 1,982 & 700 & 1,916 & 2,469 & 413 & 115 & 2037 & NA & 541 \\
\hline U1389A-5H-5, 141-142 & 40.29 & 75,533 & 37,159 & 16,671 & 775 & 4,284 & 4,859 & 1,267 & 2,946 & 5,814 & 586 & 284 & NA & NA & 888 \\
\hline U1389A-6H-5, 138-139 & 49.75 & 47,447 & 23,825 & 13,814 & NA & 969 & 1,562 & 1,039 & 2,358 & 3,220 & 528 & 131 & NA & NA & NA \\
\hline U1389A-7H-5, 135-136 & 59.21 & 147,691 & 65,714 & 19,479 & 27,977 & 4,946 & 14,488 & NA & 2,822 & 10,179 & 537 & 585 & NA & NA & 963 \\
\hline U1389C-7H-6, 132-133 & 65.66 & 59,963 & 35,912 & 11,951 & NA & 2,659 & 1,520 & 711 & 1,691 & 3,673 & 444 & 176 & 573 & NA & 653 \\
\hline U1389A-8H-6, 136-137 & 70.24 & 59,715 & 24,286 & 16,295 & 1,817 & 1,635 & 3,018 & 1,310 & 3,212 & 7,303 & 729 & 109 & NA & NA & NA \\
\hline U1389A-9H-4, 75-76 & 76.07 & 40,792 & 16,590 & 17,241 & 618 & 732 & 926 & 519 & 1,332 & 1,963 & 431 & 112 & NA & 328 & NA \\
\hline U1389A-9H-6, 130-131 & 79.72 & 49,991 & 24,754 & 16,193 & 404 & 917 & 2,294 & 648 & 1,610 & 2,133 & 310 & 105 & NA & NA & 622 \\
\hline U1389A-10H-6, 82-83 & 88.73 & 72,016 & 43,359 & 15,384 & 789 & 1,333 & 3,366 & 820 & 1,578 & 3,557 & 424 & 627 & NA & NA & 779 \\
\hline U1389A-11H-5, 122-123 & 96.72 & 44,577 & 22,040 & 14,642 & 494 & 841 & 992 & 570 & 1,567 & 2,424 & 409 & 94 & NA & NA & 503 \\
\hline U1389A-12X-3, 112-113 & 101.33 & 48,839 & 28,351 & 9,660 & 455 & 1,209 & 1,138 & 654 & 1,665 & 4,578 & 370 & 135 & 490 & 133 & NA \\
\hline U1389A-13X-5, 131-132 & 109.01 & 53,291 & 30,093 & 14,223 & 505 & 1,118 & 1,983 & NA & 1,892 & 2,834 & 543 & 101 & NA & NA & NA \\
\hline U1389A-14X-6, 143-144 & 119.10 & 66,462 & 31,171 & 16,408 & 733 & 2,354 & 5,204 & 982 & 1,922 & 6,837 & 590 & 261 & NA & NA & NA \\
\hline U1389A-15X-6, 73-74 & 129.03 & 54,182 & 23,426 & 18,771 & 569 & 1,173 & 1,562 & 1,018 & 2,352 & 4,024 & 588 & 315 & NA & 383 & NA \\
\hline U1389C-14X-6, 93-94 & 130.22 & 47,055 & 19,564 & 19,675 & 539 & 944 & 722 & 635 & 1,604 & 2,210 & 433 & 110 & NA & 283 & 336 \\
\hline U1389A-16X-5, 127-128 & 136.58 & 49,943 & 24,158 & 17,845 & NA & 979 & 1,174 & 647 & 1,382 & 2,567 & 458 & 121 & NA & NA & 612 \\
\hline U1389A-17X-5, 137-138 & 146.54 & 71,315 & 30,388 & 12,943 & 1,323 & 3,178 & 6,091 & 1,693 & 3,186 & 11,063 & 567 & 119 & NA & 764 & NA \\
\hline U1389A-18X-4, 130-131 & 155.30 & 100,055 & 41,235 & 13,794 & 2,793 & 9,906 & 9,994 & 1,812 & 3,519 & 16,208 & 458 & 335 & NA & NA & NA \\
\hline U1389A-19X-5, 129-130 & 165.01 & 61,782 & 27,728 & 15,835 & 649 & 1,394 & 6,318 & 1,328 & 2,981 & 4,473 & 562 & NA & NA & NA & 514 \\
\hline U1389A-20X-6, 115-116 & 176.36 & 97,138 & 57,314 & 15,927 & 1,161 & 2,809 & 9,758 & 1,059 & 2,466 & 4,963 & 423 & 347 & NA & NA & 911 \\
\hline U1389A-21X-5, 129-130 & 184.30 & 58,412 & 26,930 & 17,541 & NA & 5,637 & 3,170 & 596 & 1,477 & 2,444 & 505 & 111 & NA & NA & NA \\
\hline U1389A-22X-4, 128-129 & 192.92 & 47,874 & 20,114 & 14,180 & 702 & 813 & 1,683 & 1,125 & 2,109 & 5,795 & 854 & 98 & NA & 401 & NA \\
\hline U1389A-23X-4, 127-128 & 203.07 & 45,907 & 19,631 & 14,854 & 613 & 1,128 & 2,024 & 867 & 2,294 & 3,563 & 631 & 95 & NA & 207 & NA \\
\hline U1389A-24X-4, 138-139 & 212.37 & 55,644 & 29,291 & 13,073 & NA & 1,537 & 3,497 & 1,100 & 2,457 & 3,951 & 511 & 226 & NA & NA & NA \\
\hline U1389A-25X-6, 137-138 & 224.94 & 49,602 & 26,503 & 16,094 & NA & 924 & 1,264 & 687 & 1,422 & 1,554 & 438 & 131 & NA & NA & 585 \\
\hline U1389A-26X-5, 136-137 & 233.56 & 57,712 & 34,155 & 14,900 & NA & 1,043 & 3,247 & 420 & 1,019 & 1,541 & 384 & 160 & NA & NA & 843 \\
\hline U1389A-27X-6, 110-111 & 243.74 & 65,481 & 37,469 & 11,599 & 1,441 & 1,364 & 6,335 & 905 & 1,829 & 3,079 & 529 & 183 & NA & NA & 749 \\
\hline U1389A-28X-6, 120-121 & 254.00 & 64,263 & 42,489 & 14,676 & NA & 1,133 & 1,805 & 381 & 993 & 1,339 & 298 & NA & NA & NA & 1,148 \\
\hline U1389A-29X-6, 74-75 & 263.14 & 60,464 & 28,815 & 15,112 & 637 & 1,115 & 5,320 & 1,122 & 2,494 & 4,203 & 604 & 165 & NA & NA & 876 \\
\hline
\end{tabular}


Table T6 (continued). (Continued on next page.)

\begin{tabular}{|c|c|c|c|c|c|c|c|c|c|c|c|c|c|c|c|}
\hline $\begin{array}{l}\text { Hole, core, section, } \\
\text { interval }(\mathrm{cm})\end{array}$ & $\begin{array}{l}\text { Depth } \\
\text { (mbsf) }\end{array}$ & $\begin{array}{c}\text { Total } \\
\text { intensity } \\
\text { (counts) }\end{array}$ & $\begin{array}{c}\text { Quartz } \\
\text { (counts) }\end{array}$ & $\begin{array}{l}\text { Calcite } \\
\text { (counts) }\end{array}$ & $\begin{array}{c}\text { K-feldspar } \\
\text { (counts) }\end{array}$ & $\begin{array}{l}\text { Plagioclase } \\
\text { (counts) }\end{array}$ & $\begin{array}{l}\text { Dolomite } \\
\text { (counts) }\end{array}$ & $\begin{array}{l}\text { Chlorite } \\
\text { (counts) }\end{array}$ & $\begin{array}{l}\text { Kaolinite } \\
\text { (counts) }\end{array}$ & $\begin{array}{c}\text { Illite } \\
\text { (counts) }\end{array}$ & $\begin{array}{l}\text { Smectite } \\
\text { (counts) }\end{array}$ & $\begin{array}{l}\text { Hornblende } \\
\text { (counts) }\end{array}$ & $\begin{array}{l}\text { Augite } \\
\text { (counts) }\end{array}$ & $\begin{array}{c}\text { Pyrite } \\
\text { (counts) }\end{array}$ & $\begin{array}{c}\text { Aragonite } \\
\text { (counts) }\end{array}$ \\
\hline U1389A-30X-6, 128-129 & 272.32 & 41,332 & 19,917 & 11,457 & 502 & 868 & 2,612 & 663 & 1,251 & 2,439 & 587 & NA & 408 & 628 & NA \\
\hline U1389A-31X-6, 54-55 & 281.76 & 42,895 & 19,926 & 14,043 & 379 & 879 & 1,768 & 638 & 1,507 & 2,866 & 515 & 89 & NA & 284 & NA \\
\hline U1389A-32X-6, 63-64 & 291.93 & 45,426 & 23,564 & 11,230 & 514 & 1,362 & 1,452 & 850 & 1,665 & 2,847 & 707 & 400 & 533 & 302 & NA \\
\hline U1389A-33X-5, 134-135 & 300.74 & 43,224 & 16,955 & 18,383 & 319 & 719 & 977 & 829 & 1,738 & 2,517 & 492 & 138 & NA & 156 & NA \\
\hline U1389A-34X-5, 135-136 & 309.52 & 60,335 & 28,255 & 11,500 & 657 & 2,188 & 5,369 & 1,615 & 3,159 & 6,056 & 773 & 143 & NA & NA & 619 \\
\hline U1389A-35X-4, 126-127 & 317.96 & 43,598 & 20,149 & 14,565 & 563 & 791 & 1,455 & 759 & 1,955 & 2,654 & 647 & 59 & NA & NA & NA \\
\hline U1389A-36X-1, 137-138 & 323.17 & 62,328 & 36,301 & 12,856 & 552 & 2,155 & 3,075 & 965 & 2,395 & 3,122 & 813 & 93 & NA & NA & NA \\
\hline U1389A-37X-3, 115-116 & 335.55 & 59,918 & 26,775 & 14,177 & 544 & 3,301 & 4,065 & 1,512 & 2,946 & 5,283 & 647 & 667 & NA & NA & NA \\
\hline U1389E-3R-2, 76-77 & 341.76 & 52,164 & 25,632 & 14,355 & 549 & 1,341 & 2,634 & 1,017 & 2,065 & 3,297 & 486 & 109 & 678 & NA & NA \\
\hline U1389E-3R-3, 97-98 & 343.47 & 39,580 & 16,629 & 16,162 & 412 & 788 & 1,092 & NA & 1,192 & 2,203 & 476 & 183 & 443 & NA & NA \\
\hline U1389A-38X-3, 116-117 & 345.16 & 53,836 & 18,897 & 14,726 & 563 & 1,246 & 2,959 & 1,689 & 3,394 & 9,217 & 482 & 168 & 495 & NA & NA \\
\hline U1389A-39X-CC, 20-21 & 350.75 & 46,716 & 23,491 & 14,599 & NA & 1,045 & 2,421 & 682 & 1,678 & 1,922 & 376 & 92 & 409 & NA & NA \\
\hline U1389E-4R-2, 129-130 & 351.59 & 43,713 & 20,728 & 12,641 & 532 & 1,040 & 1,741 & 910 & 1,502 & 2,744 & 640 & 160 & 499 & 575 & NA \\
\hline U1389E-5R-3, 94-95 & 362.34 & 48,373 & 26,000 & 11,380 & 503 & 1,123 & 2,125 & 911 & 2,467 & 3,051 & 783 & 30 & NA & NA & NA \\
\hline U1389E-6R-1, 132-133 & 369.32 & 40,187 & 20,492 & 12,430 & 418 & 994 & 810 & 755 & 1,361 & 2,356 & 484 & 86 & NA & NA & NA \\
\hline U1389E-8R-3, 106-107 & 391.16 & 64,291 & 35,111 & 13,983 & 543 & 2,005 & 1,841 & 1,569 & 3,187 & 4,439 & 937 & 92 & NA & 583 & NA \\
\hline U1389E-9R-4, 125-126 & 402.45 & 45,902 & 23,855 & 10,310 & 503 & 1,242 & 2,985 & 879 & 1,994 & 2,899 & 534 & 91 & 478 & 132 & NA \\
\hline U1389E-10R-1, 94-96 & 407.24 & 39,294 & 18,486 & 12,150 & 480 & 889 & 940 & 675 & 1,370 & 2,479 & 708 & 132 & 427 & 557 & NA \\
\hline U1389E-11R-1, 60-61 & 416.50 & 77,293 & 47,708 & 12,523 & 636 & 2,204 & 5,784 & 1,119 & 2,645 & 3,322 & 447 & 93 & NA & NA & 811 \\
\hline U1389E-12R-3, $127-128$ & 429.77 & 53,640 & 31,176 & 12,302 & NA & 1,156 & 2,617 & 766 & 2,070 & 2,292 & 586 & NA & NA & NA & 675 \\
\hline U1389E-13R-1, 60-61 & 435.70 & 51,467 & 28,959 & 10,447 & 1,282 & 2,241 & 2,608 & 767 & 1,947 & 2,560 & 635 & 20 & NA & NA & NA \\
\hline U1389E-14R-3, 77-78 & 448.47 & 40,018 & 17,602 & 13,991 & 585 & 845 & 701 & 576 & 1,169 & 2,926 & 585 & 117 & 410 & 511 & NA \\
\hline U1389E-15R-3, 84-85 & 458.14 & 58,615 & 33,927 & 13,906 & 518 & 1,394 & 1,921 & 824 & 2,175 & 3,037 & 801 & 112 & NA & NA & NA \\
\hline U1389E-16R-1, 81-82 & 464.61 & 50,257 & 29,035 & 12,380 & 617 & 1,305 & 1,160 & 877 & 1,773 & 2,548 & 469 & 92 & NA & NA & NA \\
\hline U1389E-17R-3, 78-79 & 477.08 & 56,254 & 33,148 & 13,543 & 393 & 1,042 & 1,991 & 863 & 1,876 & 2,793 & 529 & 75 & NA & NA & NA \\
\hline U1389E-18R-1, 60-62 & 483.40 & 39,697 & 19,237 & 13,110 & 445 & 767 & 739 & 531 & 1,181 & 1,979 & 587 & NA & 505 & 616 & NA \\
\hline U1389E-19R-1, 59-61 & 492.89 & 39,811 & 18,865 & 13,265 & 468 & 974 & 1,358 & 619 & 1,244 & 2,392 & 590 & 35 & NA & NA & NA \\
\hline U1389E-20R-5, 132-133 & 509.12 & 47,733 & 26,879 & 11,048 & 416 & 1,123 & 1,931 & 952 & 2,155 & 2,449 & 671 & 108 & NA & NA & NA \\
\hline U1389E-21R-3, 99-100 & 515.29 & 71,767 & 41,278 & 13,791 & 1,214 & 1,939 & 3,160 & 1,343 & 3,421 & 4,207 & 586 & NA & NA & NA & 827 \\
\hline U1389E-22R-3, 136-137 & 525.16 & 48,404 & 23,263 & 11,412 & NA & 1,141 & 2,581 & 1,410 & 3,154 & 4,661 & 746 & 35 & NA & NA & NA \\
\hline U1389E-23R-3, 137-138 & 534.62 & 39,602 & 17,528 & 13,330 & NA & 1,311 & 1,949 & 690 & 1,213 & 2,596 & 631 & 53 & NA & 300 & NA \\
\hline U1389E-24R-5, 134-135 & 547.00 & 41,993 & 17,355 & 14,739 & 442 & 1,112 & 1,935 & NA & 1,646 & 3,850 & 761 & 153 & NA & NA & NA \\
\hline U1389E-25R-6, 49-50 & 557.79 & 65,652 & 29,075 & 13,906 & 1,608 & 2,139 & 5,812 & 1,654 & 3,819 & 5,447 & 635 & 101 & NA & 770 & 686 \\
\hline U1389E-26R-4, 128-129 & 565.18 & 55,994 & 27,048 & 11,413 & 532 & 2,959 & 3,446 & 1,621 & 3,617 & 4,668 & 588 & 102 & NA & NA & NA \\
\hline U1389E-28R-1, 60-62 & 579.20 & 51,957 & 32,386 & 10,421 & NA & 1,507 & 2,143 & 708 & 1,789 & 2,322 & 616 & 65 & NA & NA & NA \\
\hline U1389E-29R-3, 92-93 & 592.12 & 56,908 & 29,652 & 13,218 & 730 & 1,251 & 2,461 & 1,206 & 2,916 & 4,628 & 745 & 101 & NA & NA & NA \\
\hline U1389E-30R-4, 131-133 & 603.61 & 75,921 & 39,670 & 15,586 & NA & 3,341 & 5,561 & 1,581 & 3,650 & 4,955 & 741 & 91 & NA & NA & 744 \\
\hline U1389E-31R-3, 143-144 & 611.83 & 68,318 & 35,226 & 15,139 & 672 & 2,952 & 3,601 & 1,551 & 3,700 & 4,666 & 709 & 101 & NA & NA & NA \\
\hline U1389E-32R-1, 78-79 & 617.78 & 50,780 & 27,636 & 14,255 & NA & 983 & 1,362 & 756 & 2,257 & 2,366 & 535 & 124 & NA & NA & 505 \\
\hline U1389E-33R-3, 59-61 & 630.19 & 40,570 & 17,028 & 14,817 & 413 & 695 & 1,586 & 698 & 1,150 & 2,413 & 661 & NA & 467 & 642 & NA \\
\hline U1389E-34R-5, 132-133 & 643.62 & 60,504 & 32,349 & 17,980 & 405 & 1,741 & 924 & 747 & 2,090 & 2,542 & 594 & NA & NA & 513 & 619 \\
\hline U1389E-34R-6, 38-39 & 644.18 & 52,430 & 29,013 & 15,358 & NA & 1,058 & 1,504 & 587 & 1,541 & 1,700 & 563 & 77 & NA & 459 & 569 \\
\hline U1389E-35R-5, 99-100 & 653.01 & 57,893 & 34,931 & 12,489 & 1,101 & 886 & 3,280 & 659 & 1,702 & 1,827 & 430 & NA & NA & NA & 587 \\
\hline U1389E-37R-6, 137-138 & 673.30 & 61,944 & 34,931 & 13,718 & 1,101 & 1,924 & 3,280 & 883 & 2,339 & 2,528 & 493 & 125 & NA & NA & 621 \\
\hline U1389E-38R-4, 140-141 & 680.60 & 63,655 & 28,832 & 15,155 & 754 & 2,764 & 4,427 & 1,434 & 3,079 & 5,950 & 639 & 76 & NA & NA & 545 \\
\hline U1389E-39R-6, 100-101 & 692.80 & 54,472 & 27,797 & 14,763 & NA & 1,044 & 1,764 & 1,142 & 2,369 & 4,179 & 676 & 84 & NA & 653 & NA \\
\hline U1389E-40R-4, 44-45 & 698.94 & 94,524 & 56,637 & 13,232 & 2,424 & 3,397 & 7,687 & 1,392 & 3,218 & 4,842 & 506 & 105 & NA & NA & 1,084 \\
\hline U1389E-41R-3, 97-98 & 707.57 & 86,997 & 54,366 & 14,980 & 1,847 & 3,569 & 3,565 & 1,337 & 2,802 & 3,810 & 720 & NA & NA & NA & NA \\
\hline U1389E-41R-3, 130-131 & 707.90 & 54,250 & 30,346 & 13,770 & 512 & 1,037 & 1,634 & 745 & 2,244 & 2,861 & 481 & 117 & NA & 502 & NA \\
\hline U1389E-43R-3, 53-54 & 726.23 & 62,821 & 23,686 & 15,613 & 782 & 1,236 & 4,068 & 2,364 & 4,743 & 8,783 & 836 & 97 & NA & 613 & NA \\
\hline
\end{tabular}


Table T6 (continued).

\begin{tabular}{|c|c|c|c|c|c|c|c|c|c|c|c|c|c|c|c|}
\hline $\begin{array}{l}\text { Hole, core, section, } \\
\text { interval }(\mathrm{cm})\end{array}$ & $\begin{array}{l}\text { Depth } \\
\text { (mbsf) }\end{array}$ & $\begin{array}{c}\text { Total } \\
\text { intensity } \\
\text { (counts) }\end{array}$ & $\begin{array}{l}\text { Quartz } \\
\text { (counts) }\end{array}$ & $\begin{array}{l}\text { Calcite } \\
\text { (counts) }\end{array}$ & $\begin{array}{l}\text { K-feldspar } \\
\text { (counts) }\end{array}$ & $\begin{array}{l}\text { Plagioclase } \\
\text { (counts) }\end{array}$ & $\begin{array}{l}\text { Dolomite } \\
\text { (counts) }\end{array}$ & $\begin{array}{l}\text { Chlorite } \\
\text { (counts) }\end{array}$ & $\begin{array}{l}\text { Kaolinite } \\
\text { (counts) }\end{array}$ & $\begin{array}{c}\text { Illite } \\
\text { (counts) }\end{array}$ & $\begin{array}{l}\text { Smectite } \\
\text { (counts) }\end{array}$ & $\begin{array}{l}\text { Hornblende } \\
\text { (counts) }\end{array}$ & $\begin{array}{c}\text { Augite } \\
\text { (counts) }\end{array}$ & $\begin{array}{l}\text { Pyrite } \\
\text { (counts) }\end{array}$ & $\begin{array}{c}\text { Aragonite } \\
\text { (counts) }\end{array}$ \\
\hline U1389E-44R-2, 76-78 & 734.60 & 39,081 & 14,884 & 17,463 & NA & 598 & 572 & 639 & 1,427 & 2,392 & 702 & NA & NA & 404 & NA \\
\hline U1389E-46R-3, 81-82 & 755.35 & 41,325 & 17,900 & 16,148 & 446 & 863 & 877 & NA & 1,062 & 2,230 & 445 & 52 & 352 & 949 & NA \\
\hline U1389E-47R-1, 61-62 & 761.71 & 45,150 & 20,733 & 17,920 & NA & 783 & 942 & 589 & 1,335 & 1,857 & 458 & 23 & NA & 510 & NA \\
\hline U1389E-48R-2, 49-50 & 772.19 & 59,736 & 28,201 & 16,997 & NA & 3,618 & 2,179 & 1,272 & 2,315 & 3,951 & 652 & NA & NA & NA & 551 \\
\hline U1389E-49R-3, 70-71 & 783.50 & 48,533 & 17,642 & 16,803 & 497 & 1,192 & 1,967 & 1,185 & 2,017 & 6,400 & 733 & 96 & NA & NA & NA \\
\hline U1389E-50R-1, 83-84 & 790.73 & 75,766 & 39,459 & 16,350 & 2,484 & 1,832 & 6,287 & 1,368 & 2,678 & 4,326 & 867 & 115 & NA & NA & NA \\
\hline U1389E-51R-5, 117-118 & 806.64 & 41,184 & 19,305 & 14,312 & 433 & 836 & 930 & 667 & 1,292 & 2,725 & 560 & 124 & NA & NA & NA \\
\hline U1389E-52R-6, 63-64 & 816.03 & 76,075 & 39,447 & 18,989 & NA & 1,561 & 4,620 & 1,478 & 3,276 & 5,306 & 634 & NA & NA & NA & 764 \\
\hline U1389E-53R-2, 34-35 & 820.06 & 73,872 & 38,781 & 17,083 & 731 & 1,382 & 5,064 & 1,512 & 3,052 & 4,934 & 591 & NA & NA & NA & 742 \\
\hline U1389E-56R-CC & 847.75 & 79,000 & 36,243 & 18,736 & 1,042 & 1,893 & 6,901 & 1,424 & 3,869 & 7,305 & 801 & 52 & NA & NA & 732 \\
\hline U1389E-57R-6, 117-118 & 865.80 & 51,047 & 21,151 & 14,814 & 410 & 1,112 & 2,645 & 928 & 1,901 & 5,939 & 663 & 130 & NA & 1,353 & NA \\
\hline U1389E-58R-6, 64-65 & 874.86 & 62,092 & 29,552 & 17,429 & 463 & 3,065 & 2,602 & 1,243 & 2,571 & 4,007 & 588 & 86 & NA & NA & 485 \\
\hline U1389E-63R-4, 135-136 & 919.50 & 61,035 & 34,253 & 16,278 & 780 & 1,810 & 1,832 & 697 & 1,909 & 2,248 & 498 & 97 & NA & NA & 632 \\
\hline U1389E-64R-5, 98-99 & 931.48 & 52,695 & 26,622 & 18,185 & NA & 754 & 1,704 & 774 & 1,854 & 2,237 & 456 & 108 & NA & NA & NA \\
\hline U1389E-65R-6, 133-134 & 942.83 & 53,782 & 25,266 & 17,593 & NA & 1,326 & 2,977 & 821 & 2,428 & 2,850 & 495 & 25 & NA & NA & NA \\
\hline U1389E-67R-3, 57-58 & 955.63 & 67,933 & 32,126 & 21,179 & 1,130 & 1,036 & 4,304 & 1,306 & 2,573 & 3,702 & 576 & NA & NA & NA & NA \\
\hline U1389E-70R-1, 62-63 & 982.52 & 61,662 & 31,320 & 17,614 & 439 & 1,300 & 2,245 & 1,127 & 3,188 & 3,690 & 423 & 88 & NA & 228 & NA \\
\hline
\end{tabular}

$\mathrm{NA}=$ no peak detected. 
Table T7. Biostratigraphic datums, Site U1389.

\begin{tabular}{|c|c|c|c|c|c|c|c|c|c|c|c|c|c|c|}
\hline \multirow[b]{2}{*}{ Event } & \multirow[b]{2}{*}{ Reference } & \multirow{2}{*}{$\begin{array}{l}\text { Age } \\
\text { (Ma) }\end{array}$} & \multicolumn{3}{|c|}{ Hole U1389A depth (mbsf) } & \multicolumn{3}{|c|}{ Hole U1389B depth (mbsf) } & \multicolumn{3}{|c|}{ Hole U1389C depth (mbsf) } & \multicolumn{3}{|c|}{ Hole U1389E depth (mbsf) } \\
\hline & & & Top & Bottom & Mean & Top & Bottom & Mean & Top & Bottom & Mean & Top & & Mean \\
\hline LrO Emiliania huxleyi (>4 $\mu \mathrm{m})$ & Flores et al., 2010 & 0.01 & 2.25 & 3.75 & 3.00 & 0.00 & 9.72 & 4.86 & 0.00 & 9.74 & 4.87 & & & \\
\hline FO Emiliania huxleyi & Raffi et al., 2006 & 0.26 & 91.96 & 93.37 & 92.62 & & & & 111.64 & 122.26 & 116.95 & & & \\
\hline LO Pseudoemiliania lacunosa & Raffi et al., 2006 & 0.46 & 208.73 & 210.56 & 209.64 & & & & 211.52 & 221.12 & 216.32 & & & \\
\hline LO Reticulofenestra asanoi & Raffi et al., 2006 & 0.90 & 322.63 & 332.55 & 327.59 & & & & 326.90 & 327.44 & 327.17 & & & \\
\hline FO Reticulofenestra asanoi & Raffi et al., 2006 & 1.07 & & & & & & & & & & 360.65 & 362.15 & 361.40 \\
\hline $\begin{array}{l}\text { T paracme Neogloboquadrina } \\
\text { pachyderma (sin) }\end{array}$ & Lourens et al., 2004 & 1.21 & & & & & & & & & & 368.62 & 369.54 & 369.08 \\
\hline LO large Gephyrocapsa $(>5.5 \mu \mathrm{m})$ & Raffi et al., 2006 & 1.24 & & & & & & & & & & 377.66 & 387.99 & 382.83 \\
\hline LO Helicosphaera sellii & Raffi et al., 2006 & 1.25 & & & & & & & & & & 377.66 & 387.99 & 382.83 \\
\hline $\begin{array}{l}\text { B paracme Neogloboquadrina } \\
\text { pachyderma (sin) }\end{array}$ & Lourens et al., 2004 & 1.37 & & & & & & & & & & 421.80 & 433.73 & 427.77 \\
\hline FO large Gephyrocapsa $(>5.5 \mu \mathrm{m})$ & Raffi et al., 2006 & 1.61 & & & & & & & & & & 477.07 & 478.57 & 477.82 \\
\hline LO Calcidiscus macintyrei & Raffi et al., 2006 & 1.66 & & & & & & & & & & 510.09 & 515.65 & 512.87 \\
\hline FO Globorotalia inflata & Lourens et al., 2004 & 2.09 & & & & & & & & & & 627.21 & 630.21 & 628.71 \\
\hline LO Globorotalia puncticulata & Lourens et al., 2004 & 2.41 & & & & & & & & & & 645.02 & 646.61 & 645.82 \\
\hline LO Discoaster pentaradiatus & Raffi et al., 2006 & 2.50 & & & & & & & & & & 674.25 & 681.98 & 678.12 \\
\hline LO Discoaster surculus & Raffi et al., 2006 & 2.53 & & & & & & & & & & 681.98 & 693.70 & 687.84 \\
\hline LO Discoaster tamalis & Raffi et al., 2006 & 2.80 & & & & & & & & & & 737.96 & 751.54 & 744.75 \\
\hline $\begin{array}{l}\text { Coiling change Globorotalia } \\
\text { crassaformis }\end{array}$ & $\begin{array}{l}\text { Zachariasse et al. (1989); } \\
\text { Lourens (pers. comm, } \\
\text { 2012) }\end{array}$ & 2.99 & & & & & & & & & & 764.48 & 772.41 & 768.45 \\
\hline LO Dentoglobigerina altispira & Lourens et al., 2004 & 3.17 & & & & & & & & & & 830.21 & 838.21 & 834.21 \\
\hline LO Sphaeroidinella seminulina & Lourens et al., 2004 & 3.19 & & & & & & & & & & 830.21 & 838.21 & 834.21 \\
\hline $\begin{array}{l}\text { Reappearance Globorotalia } \\
\text { puncticulata }\end{array}$ & Lourens et al., 2004 & 3.31 & & & & & & & & & & 860.70 & 863.74 & 862.22 \\
\hline $\begin{array}{l}\text { Disappearance Globorotalia } \\
\text { puncticulata }\end{array}$ & Lourens et al., 2004 & 3.57 & & & & & & & & & & 932.13 & 934.61 & 933.37 \\
\hline
\end{tabular}

$\mathrm{LrO}=$ last regular occurrence, $\mathrm{FO}=$ first occurrence, $\mathrm{LO}=$ last occurrence, $\mathrm{T}=$ top, $\mathrm{B}=$ bottom. $\sin =$ sinistral. 


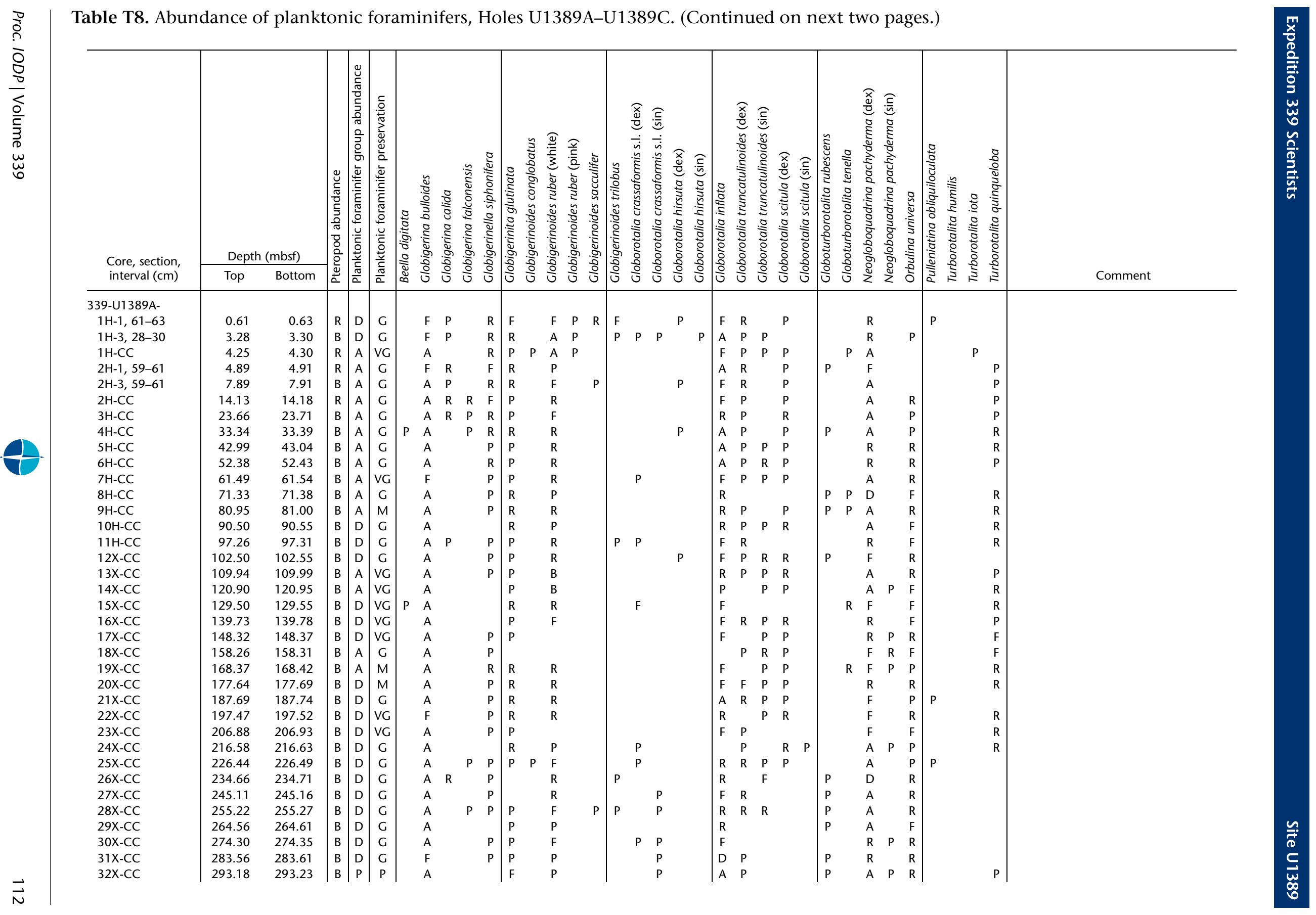




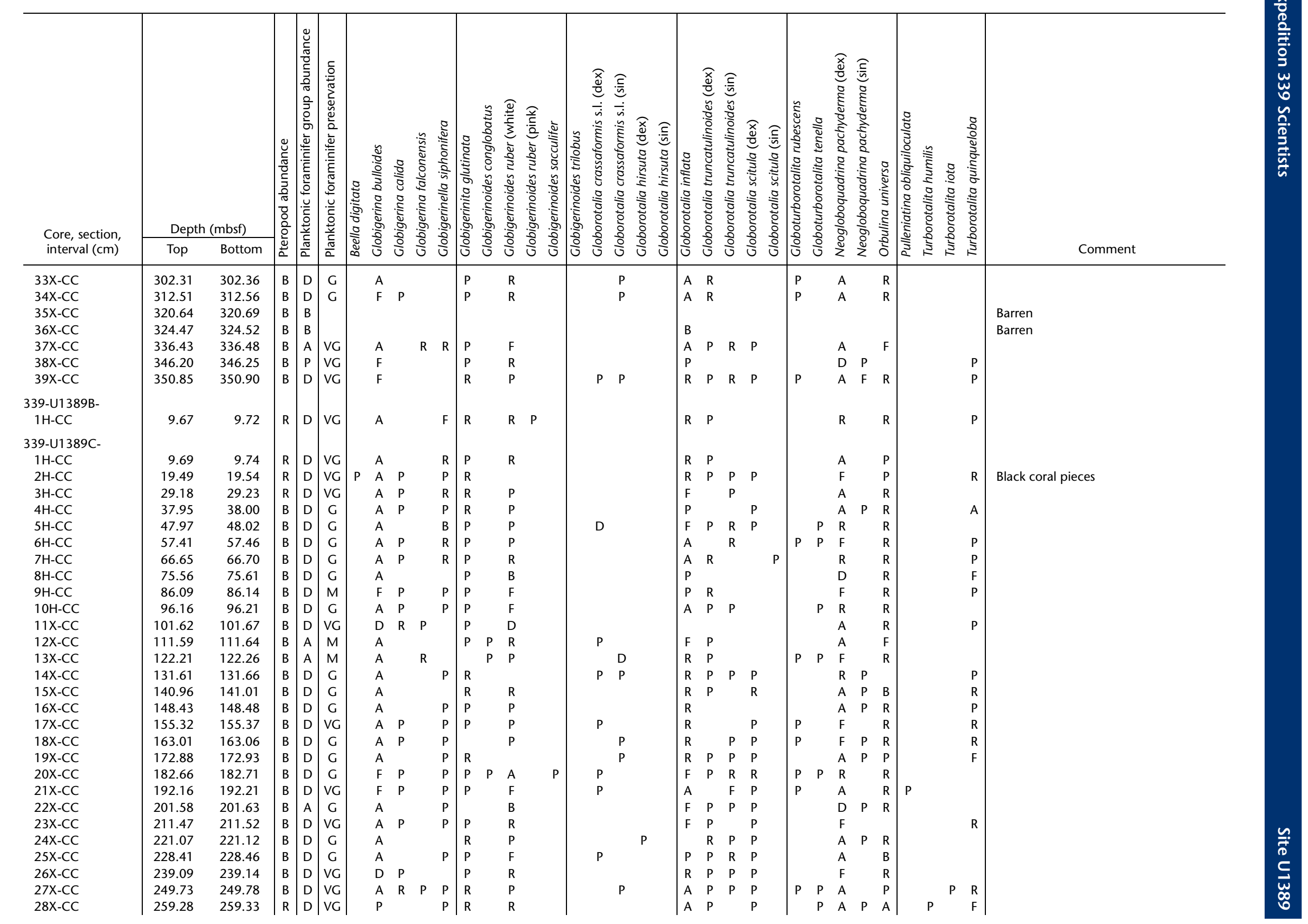




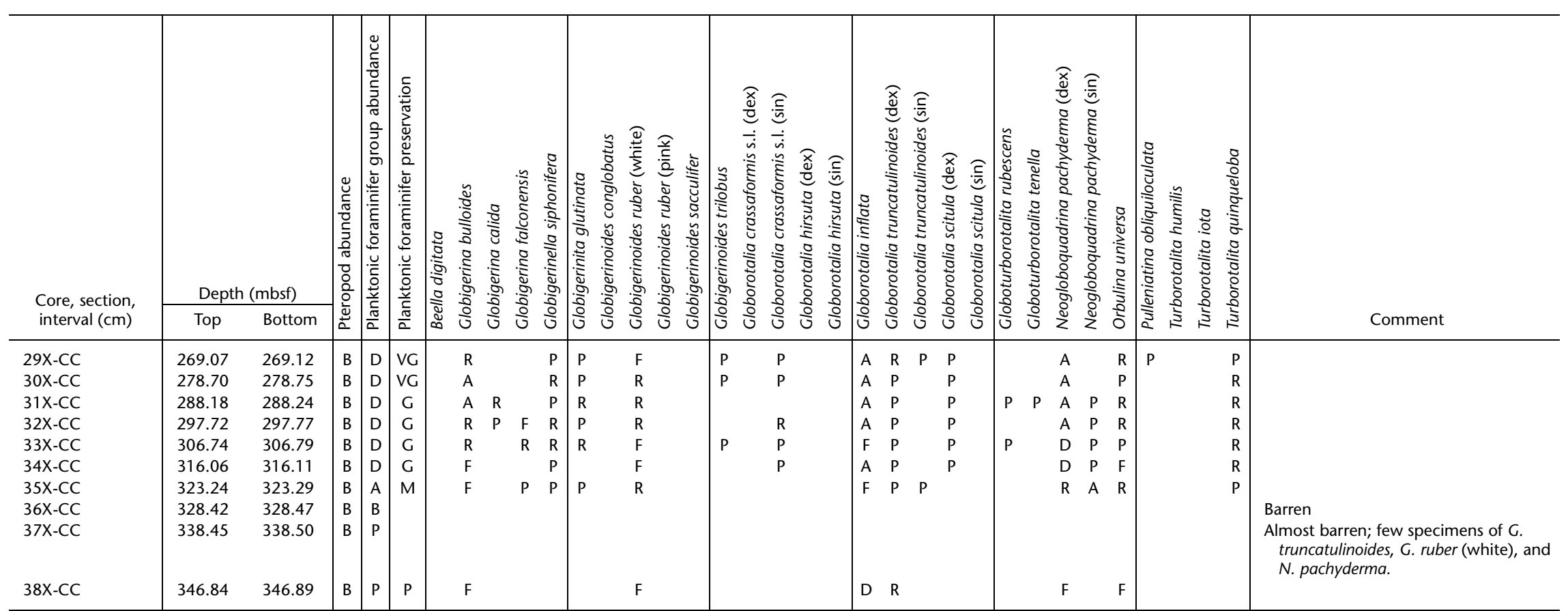

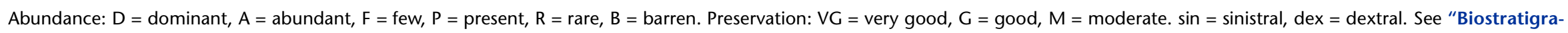
phy" in the "Methods" chapter (Expedition 339 Scientists, 2013b) for abundance and preservation definitions.

Table T9. Abundance of planktonic foraminifers, Hole U1389E. This table is available in an oversized format.

Table T10. Abundance of nannofossils, Site U1389. This table is available in an oversized format.

Table T11. Abundance of benthic foraminifers, Site U1389. This table is available in an oversized format. 


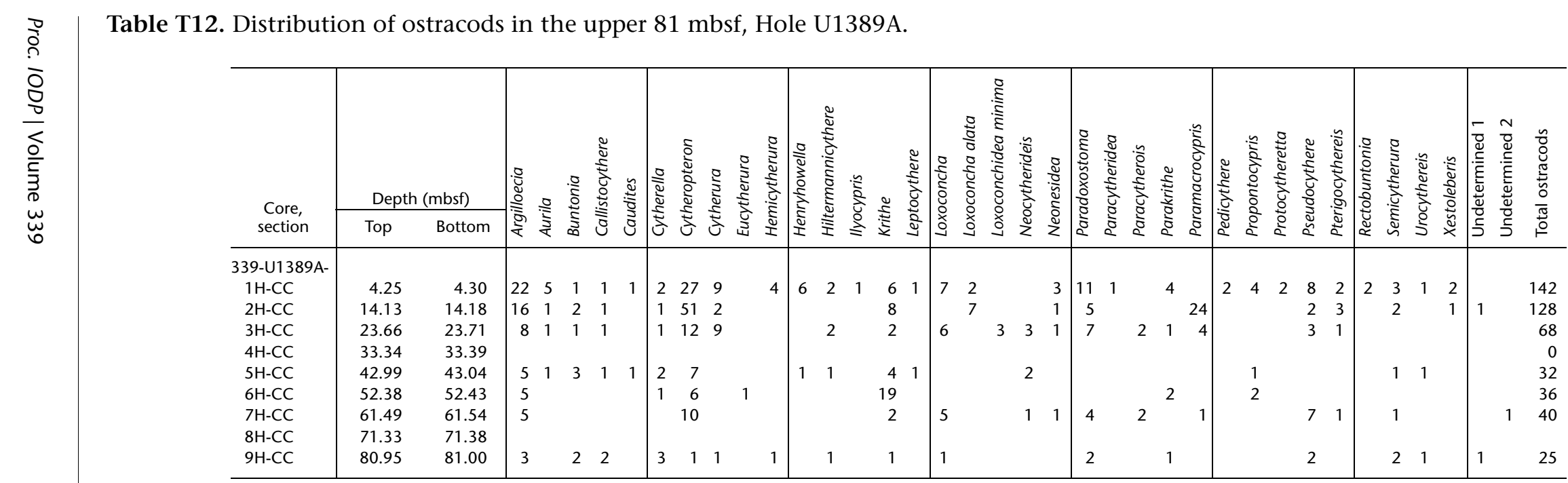




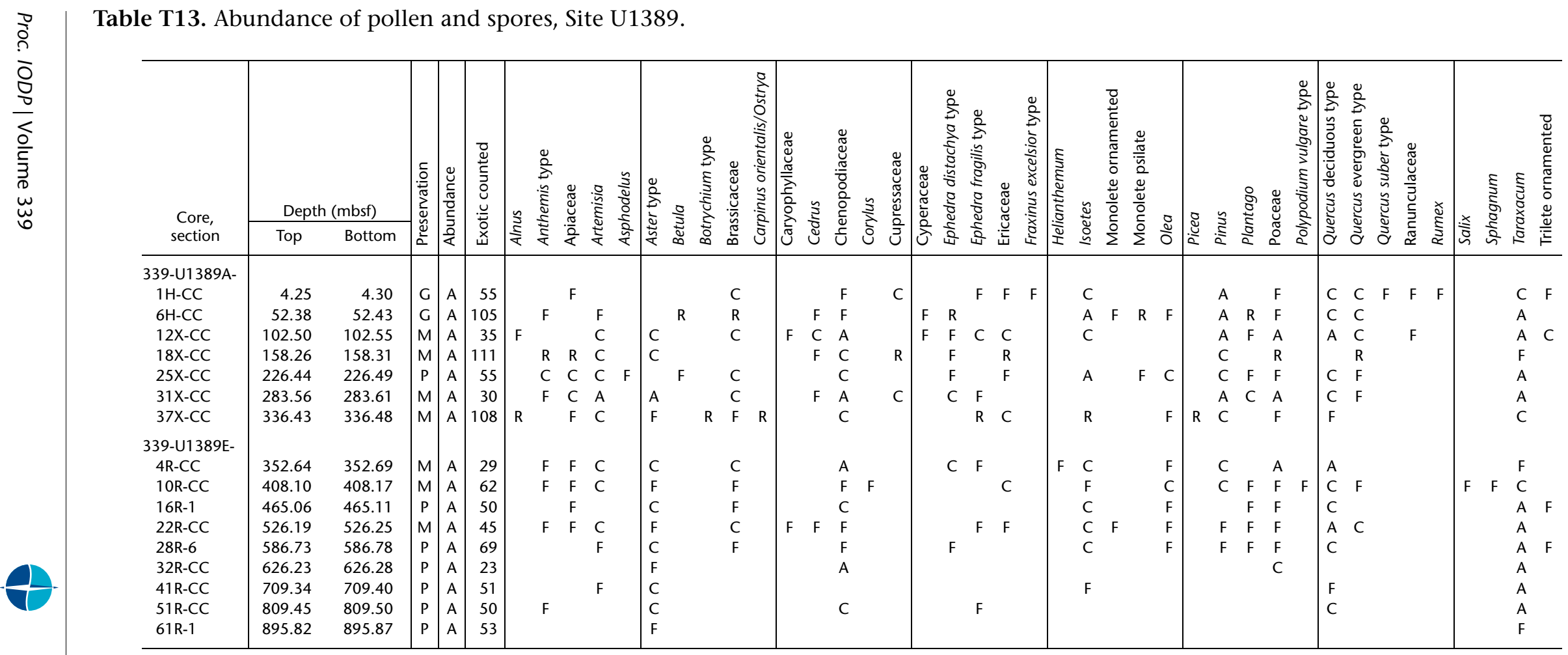

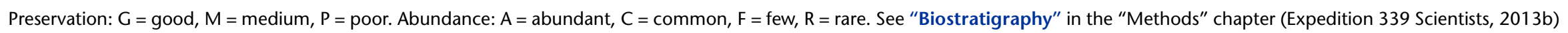
for abundance and preservation definitions. 
Table T14. Disturbed intervals, Site U1389. (Continued on next three pages.)

\begin{tabular}{|c|c|c|}
\hline \multirow{2}{*}{$\begin{array}{l}\text { Core, section, } \\
\text { interval }(\mathrm{cm})\end{array}$} & \multicolumn{2}{|r|}{ Drilling disturbance } \\
\hline & Intensity & Comment \\
\hline \multicolumn{3}{|l|}{ 339-U1389A- } \\
\hline $1 \mathrm{H}-1$ & Moderate & Slightly soupy mudline extending downhole to $\sim 8 \mathrm{~cm}$, but do not cull data in this interval. \\
\hline $1 \mathrm{H}-1,145-150$ & High & IW tube sample \\
\hline $1 \mathrm{H}-2,145-150$ & High & Whole-round IW sample \\
\hline $2 \mathrm{H}-1,0-8$ & Moderate & Disturbed core top \\
\hline $2 \mathrm{H}-1,142-150$ & High & IW tube sample \\
\hline $2 \mathrm{H}-2,145-150$ & High & IW tube sample \\
\hline $2 \mathrm{H}-3,145-150$ & High & IW tube sample \\
\hline $2 \mathrm{H}-4,145-150$ & High & IW tube sample \\
\hline $2 \mathrm{H}-5,142-150$ & High & IW tube sample \\
\hline $2 \mathrm{H}-6,146-152$ & High & Whole-round IW sample \\
\hline $3 \mathrm{H}-1,132-141$ & High & IW tube sample \\
\hline $3 \mathrm{H}-2,145-150$ & High & IW tube sample \\
\hline $3 \mathrm{H}-3,145-150$ & High & IW tube sample \\
\hline $3 \mathrm{H}-4,145-150$ & High & IW tube sample \\
\hline $3 \mathrm{H}-5,145-150$ & High & IW tube sample \\
\hline $3 \mathrm{H}-6,145-150$ & High & Whole-round IW sample \\
\hline $4 \mathrm{H}-1,145-150$ & High & IW tube sample \\
\hline $4 \mathrm{H}-2,145-150$ & High & IW tube sample \\
\hline $4 \mathrm{H}-3,145-150$ & High & IW tube sample \\
\hline $4 \mathrm{H}-4,145-150$ & High & IW tube sample \\
\hline $4 \mathrm{H}-5,145-150$ & High & IW tube sample \\
\hline $4 \mathrm{H}-6,149-154$ & High & Whole-round IW sample \\
\hline $5 \mathrm{H}-1,0-4$ & Moderate & Disturbed core top \\
\hline $5 \mathrm{H}-1,140-150$ & High & IW tube sample \\
\hline $5 \mathrm{H}-2,145-150$ & High & IW tube sample \\
\hline $5 \mathrm{H}-3,145-150$ & High & IW tube sample \\
\hline $5 \mathrm{H}-4,145-150$ & High & IW tube sample \\
\hline $5 \mathrm{H}-5,145-150$ & High & IW tube sample \\
\hline $5 \mathrm{H}-6,151-155$ & High & Whole-round IW sample \\
\hline $6 \mathrm{H}-1,0-4$ & Moderate & Disturbed core top \\
\hline $6 \mathrm{H}-1,142-150$ & High & IW tube sample \\
\hline $6 \mathrm{H}-2,143-150$ & High & IW tube sample \\
\hline $6 \mathrm{H}-3,145-150$ & High & IW tube sample \\
\hline $6 \mathrm{H}-4,145-150$ & High & IW tube sample \\
\hline $6 \mathrm{H}-5,145-150$ & High & IW tube sample \\
\hline $6 \mathrm{H}-6,148-152$ & High & Whole-round IW sample \\
\hline 7H-1, 140-150 & High & IW tube sample \\
\hline $7 \mathrm{H}-2,140-150$ & High & IW tube sample \\
\hline $7 \mathrm{H}-3,140-150$ & High & IW tube sample \\
\hline $7 \mathrm{H}-4,140-150$ & High & IW tube sample \\
\hline $7 \mathrm{H}-5,140-150$ & High & IW tube sample \\
\hline 7H-6, 120-126 & High & Whole-round IW sample \\
\hline $8 \mathrm{H}-1,0-3$ & Moderate & Disturbed core top \\
\hline $8 \mathrm{H}-1,140-150$ & High & IW tube sample \\
\hline $8 \mathrm{H}-2,141-151$ & High & IW tube sample \\
\hline $8 \mathrm{H}-3,141-151$ & High & IW tube sample \\
\hline $8 \mathrm{H}-4,143-153$ & High & IW tube sample \\
\hline $8 \mathrm{H}-5,142-152$ & High & IW tube sample \\
\hline $8 \mathrm{H}-6,150-155$ & High & Whole-round IW sample \\
\hline $9 \mathrm{H}-1,137-147$ & High & IW tube sample \\
\hline $9 \mathrm{H}-2,141-151$ & High & IW tube sample \\
\hline $9 \mathrm{H}-3,143-153$ & High & IW tube sample \\
\hline $9 \mathrm{H}-4,146-156$ & High & IW tube sample \\
\hline $9 \mathrm{H}-5,146-156$ & High & IW tube sample \\
\hline $9 \mathrm{H}-6,147-152$ & High & Whole-round IW sample \\
\hline $10 \mathrm{H}-1,0-3$ & High & Disturbed core top \\
\hline $10 \mathrm{H}-1,136-146$ & High & IW tube sample \\
\hline $10 \mathrm{H}-2,141-151$ & High & IW tube sample \\
\hline $10 \mathrm{H}-3,144-154$ & High & IW tube sample \\
\hline $10 \mathrm{H}-4,145-155$ & High & IW tube sample \\
\hline $10 \mathrm{H}-5,145-155$ & High & IW tube sample \\
\hline $10 \mathrm{H}-6,140-145$ & High & Whole-round IW sample \\
\hline $11 \mathrm{H}-1,0-2$ & High & Disturbed core top \\
\hline $11 \mathrm{H}-1,130-140$ & High & IW tube sample \\
\hline $11 \mathrm{H}-2,130-140$ & High & IW tube sample \\
\hline $11 \mathrm{H}-3,131-141$ & High & IW tube sample \\
\hline $11 \mathrm{H}-4,140-146$ & High & Whole-round IW sample \\
\hline
\end{tabular}


Table T14 (continued). (Continued on next page.)

\begin{tabular}{|c|c|c|}
\hline \multirow{2}{*}{$\begin{array}{l}\text { Core, section } \\
\text { interval }(\mathrm{cm})\end{array}$} & \multicolumn{2}{|r|}{ Drilling disturbance } \\
\hline & Intensity & Comment \\
\hline $12 X-2,140-150$ & High & Whole-round IW sample \\
\hline $13 X-4,139-150$ & High & Whole-round IW sample \\
\hline $14 X-5,139-150$ & High & Whole-round IW sample \\
\hline $15 X-4,140-150$ & High & Whole-round IW sample \\
\hline $16 X-1,0-51$ & High & Disturbed core top \\
\hline $16 X-5,140-150$ & High & Whole-round IW sample \\
\hline $17 X-4,140-150$ & High & Whole-round IW sample \\
\hline $18 X-4,140-150$ & High & Whole-round IW sample \\
\hline $19 X-1,0-18$ & Moderate & Disturbed core top \\
\hline $19 X-5,140-150$ & High & Whole-round IW sample \\
\hline $20 X-1,0-8$ & Moderate & Disturbed core top \\
\hline $20 X-4,140-150$ & High & Whole-round IW sample \\
\hline $21 X-1,0-41$ & Moderate & Disturbed core top \\
\hline $21 X-5,140-150$ & High & Whole-round IW sample \\
\hline $22 X-4,140-150$ & High & Whole-round IW sample \\
\hline $23 X-1,0-9$ & Moderate & Disturbed core top \\
\hline $23 X-4,140-150$ & High & Whole-round IW sample \\
\hline $25 X-1,0-3$ & High & Disturbed core top \\
\hline $26 X-1,0-14$ & High & Disturbed core top \\
\hline $26 X-3,140-150$ & High & Whole-round IW sample \\
\hline $27 X-1,0-3$ & High & Disturbed core top \\
\hline $28 X-1,0-6$ & High & Disturbed core top \\
\hline $28 X-7,45-47$ & void & Void \\
\hline $29 X-6,100-110$ & High & Whole-round IW sample \\
\hline $30 x-1,0-3$ & High & Disturbed core top \\
\hline $32 X-6,90-101$ & High & Whole-round IW sample \\
\hline $33 X-6,64-70$ & void & Void \\
\hline $35 X-4,139-150$ & High & Whole-round IW sample \\
\hline $36 X-1,0-6$ & High & Disturbed core top \\
\hline $37 X-3,0-0$ & High & $\begin{array}{l}\text { Interval from } 0 \text { to } 24 \mathrm{~cm} \text { is a very soupy sand. This is an example of what occurs in several of } \\
\text { the sandy intervals and may be related to the occurrence of hydrates or fluid motion in the } \\
\text { expanding cores. These intervals are not culled because the sands are important constituents } \\
\text { of the core, although physical and magnetic properties are likely highly disturbed. }\end{array}$ \\
\hline $38 X-2,140-150$ & High & Whole-round IW sample \\
\hline $39 X-1,0-12$ & High & Disturbed core top \\
\hline \multicolumn{3}{|l|}{ 339-U1389C- } \\
\hline $1 \mathrm{H}-1,0-6$ & High & Very soupy mudline \\
\hline $3 \mathrm{H}-1,0-4$ & Moderate & Disturbed core top \\
\hline $4 \mathrm{H}-1,0-14$ & Moderate & Disturbed core top \\
\hline $5 \mathrm{H}-1,0-29$ & Moderate & Disturbed core top \\
\hline $6 \mathrm{H}-1,0-11$ & Moderate & Disturbed core top \\
\hline $8 \mathrm{H}-1,0-11$ & High & Disturbed core top \\
\hline $10 \mathrm{H}-1,0-18$ & Moderate & Disturbed core top \\
\hline $10 \mathrm{H}-2,0-2$ & High & Void \\
\hline $11 X-1,0-3$ & Moderate & Disturbed core top \\
\hline $12 X-1,0-4$ & High & Disturbed core top \\
\hline $15 X-1,0-4$ & Moderate & Disturbed core top \\
\hline $16 X-1,0-16$ & Moderate & Disturbed core top \\
\hline $17 X-1,0-9$ & Moderate & Disturbed core top \\
\hline $19 X-1,0-3$ & Moderate & Disturbed core top \\
\hline $20 X-1,60-62$ & void & Void \\
\hline $21 X-1,0-13$ & Moderate & Disturbed core top \\
\hline $22 X-1,0-24$ & Moderate & Disturbed core top \\
\hline $23 x-1,0-6$ & Moderate & Disturbed core top \\
\hline $24 X-1,0-8$ & Moderate & Disturbed core top \\
\hline $25 X-1,0-15$ & Moderate & Disturbed core top \\
\hline $26 X-1,0-12$ & Moderate & Disturbed core top \\
\hline $27 X-1,0-12$ & High & Disturbed core top \\
\hline $30 x-1,0-16$ & High & Disturbed core top \\
\hline $31 X-1,0-3$ & High & Disturbed core top \\
\hline $32 X-1,0-11$ & Moderate & Disturbed core top \\
\hline $33 X-1,0-30$ & Moderate & Disturbed core top \\
\hline $33 x-7,40-43$ & void & Void \\
\hline $34 X-1,0-9$ & Moderate & Disturbed core top \\
\hline $36 X-1,0-2$ & Moderate & Disturbed core top \\
\hline \multicolumn{3}{|l|}{ 339-U1389D- } \\
\hline $1 \mathrm{H}-1$ & Moderate & Slightly soupy mudline extending downhole to $\sim 8 \mathrm{~cm}$, but do not cull data in this interval. \\
\hline $4 \mathrm{H}-1,0-15$ & Moderate & Disturbed core top \\
\hline
\end{tabular}


Table T14 (continued). (Continued on next page.)

\begin{tabular}{|c|c|c|c|}
\hline Core, section & & & urbance \\
\hline interval $(\mathrm{cm})$ & Intensity & & Comment \\
\hline $6 \mathrm{H}-1,0-38$ & High & Disturbed core top & \\
\hline $7 \mathrm{H}-1,0-17$ & High & Disturbed core top & \\
\hline $8 \mathrm{H}-1,0-4$ & Moderate & Disturbed core top & \\
\hline $9 \mathrm{H}-1,0-71$ & Moderate & Disturbed core top & \\
\hline $10 \mathrm{H}-1,0-15$ & Moderate & Disturbed core top & \\
\hline 339-U1389E- & & & \\
\hline 2R-1, 0-10 & Moderate & Disturbed core top & \\
\hline $2 \mathrm{R}-1,80-100$ & High & Disturbed & \\
\hline $3 R-1,0-4$ & High & Disturbed core top & \\
\hline $3 R-2,8-15$ & High & Disturbed & \\
\hline $3 R-4,35-43$ & High & Disturbed & \\
\hline $4 \mathrm{R}-2,140-150$ & High & Whole-round IW sample & \\
\hline $5 \mathrm{R}-1,70-80$ & High & Disturbed & \\
\hline $5 R-3,0-6$ & High & Disturbed & \\
\hline $6 \mathrm{R}-1,0-5$ & High & Disturbed core top & \\
\hline $8 R-1,0-5$ & High & Disturbed core top & \\
\hline $8 R-1,66-76$ & High & Disturbed & \\
\hline $8 \mathrm{R}-1,140-150$ & High & Whole-round IW sample & \\
\hline $9 \mathrm{R}-1,0-6$ & High & Disturbed core top & \\
\hline $11 \mathrm{R}-1,0-7$ & High & Disturbed core top & \\
\hline $11 \mathrm{R}-3,140-150$ & High & Whole-round IW sample & \\
\hline $11 \mathrm{R}-4,135-145$ & High & Whole-round IW sample & \\
\hline $12 \mathrm{R}-6,67-73$ & High & PAL whole-round sample & \\
\hline $13 \mathrm{R}-1,0-10$ & High & Disturbed core top & \\
\hline $13 \mathrm{R}-1,111-117$ & Moderate & Disturbed & \\
\hline $13 R-6,67-73$ & High & PAL whole-round sample & \\
\hline $14 \mathrm{R}-1,0-16$ & Moderate & Disturbed core top & \\
\hline $14 \mathrm{R}-3,140-150$ & High & Whole-round IW sample & \\
\hline $14 \mathrm{R}-4,0-5$ & High & Disturbed & \\
\hline $14 R-4,100-105$ & High & PAL whole-round sample & \\
\hline 15R-1, 0-19 & High & Disturbed core top & \\
\hline $15 R-4,65-70$ & High & PAL whole-round sample & \\
\hline $16 \mathrm{R}-1,126-132$ & High & PAL whole-round sample & \\
\hline $17 \mathrm{R}-2,140-150$ & High & Whole-round IW sample & \\
\hline 19R-1, 0-10 & High & Disturbed core top & \\
\hline $19 \mathrm{R}-2,0-30$ & High & Disturbed & \\
\hline $20 \mathrm{R}-1,0-50$ & High & Disturbed core top & \\
\hline $20 \mathrm{R}-3,140-150$ & High & Whole-round IW sample & \\
\hline 20R-5, 90-110 & High & Disturbed & \\
\hline $20 \mathrm{R}-6,0-25$ & High & Disturbed & \\
\hline $21 \mathrm{R}-2,35-65$ & High & Disturbed & \\
\hline $21 \mathrm{R}-2,65-91$ & High & Void & \\
\hline $23 R-2,140-150$ & High & Whole-round IW sample & \\
\hline $24 \mathrm{R}-1,0-6$ & High & Disturbed core top & \\
\hline $24 \mathrm{R}-2,70-110$ & High & Disturbed & \\
\hline $25 \mathrm{R}-4,40-150$ & High & Disturbed & \\
\hline 25R-5, 70-102 & High & Void and disturbed & \\
\hline $26 \mathrm{R}-4,140-150$ & High & Whole-round IW sample & \\
\hline $27 \mathrm{R}-1,83-86$ & High & Disturbed & \\
\hline $28 \mathrm{R}-3,104-113$ & Moderate & Disturbed & \\
\hline $28 \mathrm{R}-6,13-30$ & High & Disturbed & \\
\hline $28 \mathrm{R}-6,63-68$ & High & PAL whole-round sample & \\
\hline $29 R-4,68-80$ & High & Disturbed & \\
\hline $30 \mathrm{R}-1,140-150$ & High & Whole-round IW sample & \\
\hline $30 \mathrm{R}-3,109-120$ & High & Soupy & \\
\hline $31 \mathrm{R}-5,80-95$ & High & Disturbed & \\
\hline $32 \mathrm{R}-3,140-150$ & High & Whole-round IW sample & \\
\hline $32 \mathrm{R}-5,100-107$ & High & Disturbed & \\
\hline $32 \mathrm{R}-6,77-100$ & Moderate & Disturbed & \\
\hline $33 \mathrm{R}-1,0-9$ & High & Disturbed core top & \\
\hline $33 R-1,62-69$ & High & Disturbed & \\
\hline $33 R-2,82-95$ & High & Disturbed & \\
\hline $34 \mathrm{R}-1,0-3$ & High & Disturbed core top & \\
\hline $34 \mathrm{R}-2,36-70$ & High & Disturbed & \\
\hline $34 \mathrm{R}-5,0-10$ & High & Disturbed & \\
\hline $35 \mathrm{R}-1,0-2$ & High & Disturbed core top & \\
\hline $35 R-3,140-150$ & High & Whole-round IW sample & \\
\hline $37 \mathrm{R}-1,45-120$ & High & Disturbed & \\
\hline
\end{tabular}


Table T14 (continued).

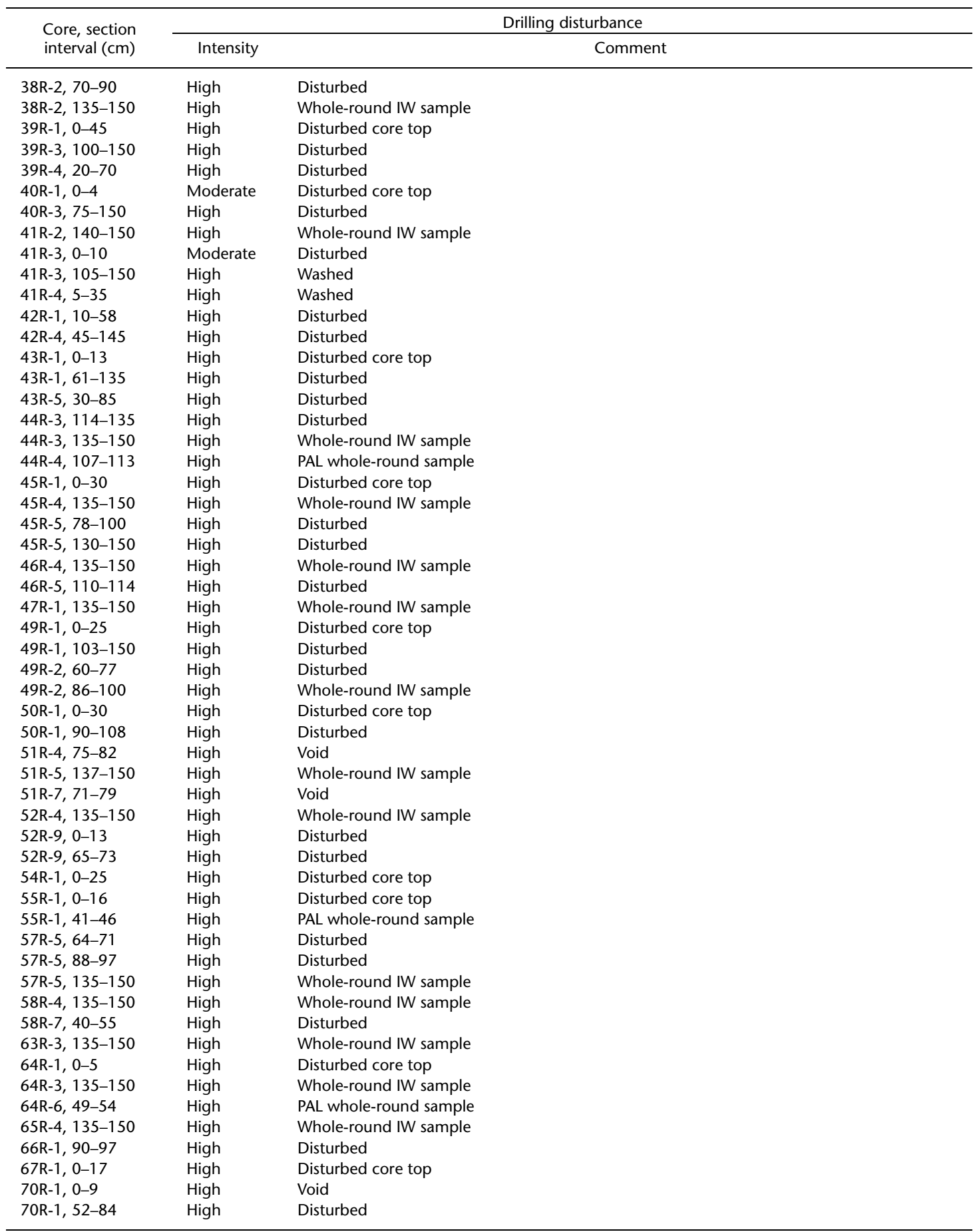

$\mathrm{IW}=$ interstitial water, $\mathrm{MBIO}=$ microbiology sample, $\mathrm{PAL}=$ paleontology . 
Table T15. NRM inclination, declination, and intensity data after $20 \mathrm{mT}$ peak field AF demagnetization, Hole U1389A.

\begin{tabular}{|c|c|c|c|c|c|}
\hline $\begin{array}{l}\text { Core, section, } \\
\text { interval }(\mathrm{cm})\end{array}$ & $\begin{array}{l}\text { Depth } \\
\text { (mbsf) }\end{array}$ & $\begin{array}{c}\text { Inclination } \\
\left({ }^{\circ}\right)\end{array}$ & $\begin{array}{l}\text { Declination } \\
\left({ }^{\circ}\right)\end{array}$ & $\begin{array}{c}\text { Flexlt- } \\
\text { corrected } \\
\text { declination } \\
\left(^{\circ}\right)\end{array}$ & $\begin{array}{l}\text { Intensity } \\
(\mathrm{A} / \mathrm{m})\end{array}$ \\
\hline \multicolumn{6}{|l|}{ 339-U1389A- } \\
\hline $1 \mathrm{H}-1$ & 0.00 & & & & \\
\hline $1 \mathrm{H}-1,5$ & 0.05 & & & & \\
\hline $1 \mathrm{H}-1,10$ & 0.10 & & & & \\
\hline $1 \mathrm{H}-1,15$ & 0.15 & 61.6 & 351.5 & & 0.010025 \\
\hline $1 \mathrm{H}-1,20$ & 0.20 & 57.4 & 349.9 & & 0.0118 \\
\hline $1 \mathrm{H}-1,25$ & 0.25 & 56.6 & 349.2 & & 0.011925 \\
\hline $1 \mathrm{H}-1,30$ & 0.30 & 50.4 & 0.6 & & 0.012842 \\
\hline $1 \mathrm{H}-1,35$ & 0.35 & 48.4 & 6.4 & & 0.013295 \\
\hline $1 \mathrm{H}-1,40$ & 0.40 & 51.3 & 7.6 & & 0.011352 \\
\hline $1 \mathrm{H}-1,45$ & 0.45 & 52.2 & 11 & & 0.009988 \\
\hline $1 \mathrm{H}-1,50$ & 0.50 & 47.7 & 9.8 & & 0.010458 \\
\hline $1 \mathrm{H}-1,55$ & 0.55 & 42.1 & 11.4 & & 0.012205 \\
\hline $1 \mathrm{H}-1,60$ & 0.60 & 43 & 10.4 & & 0.011993 \\
\hline $1 \mathrm{H}-1,65$ & 0.65 & 43.4 & 7.2 & & 0.011121 \\
\hline $1 \mathrm{H}-1,70$ & 0.70 & 42.4 & 8.5 & & 0.0107 \\
\hline $1 \mathrm{H}-1,75$ & 0.75 & 45.1 & 8.1 & & 0.011568 \\
\hline $1 \mathrm{H}-1,80$ & 0.80 & 49.8 & 8.7 & & 0.010967 \\
\hline $1 \mathrm{H}-1,85$ & 0.85 & 51.7 & 16.3 & & 0.010172 \\
\hline $1 \mathrm{H}-1,90$ & 0.90 & 52.8 & 27.6 & & 0.009744 \\
\hline $1 \mathrm{H}-1,95$ & 0.95 & 56.5 & 28.2 & & 0.010495 \\
\hline $1 \mathrm{H}-1,100$ & 1.00 & 55.6 & 24.6 & & 0.012737 \\
\hline $1 \mathrm{H}-1,105$ & 1.05 & 54.2 & 27 & & 0.014934 \\
\hline $1 \mathrm{H}-1,110$ & 1.10 & 55.2 & 32 & & 0.014654 \\
\hline $1 \mathrm{H}-1,115$ & 1.15 & 54.8 & 31.9 & & 0.014148 \\
\hline $1 \mathrm{H}-1,120$ & 1.20 & 53.1 & 32.1 & & 0.014791 \\
\hline $1 \mathrm{H}-1,125$ & 1.25 & 53.5 & 32.5 & & 0.015012 \\
\hline $1 \mathrm{H}-1,130$ & 1.30 & 52.3 & 43.9 & & 0.014701 \\
\hline $1 \mathrm{H}-1,135$ & 1.35 & 52.7 & 63.9 & & 0.014474 \\
\hline $1 \mathrm{H}-1,140$ & 1.40 & & & & \\
\hline $1 \mathrm{H}-1,145$ & 1.45 & & & & \\
\hline $1 \mathrm{H}-1,150$ & 1.50 & & & & \\
\hline $1 \mathrm{H}-2$ & 1.50 & & & & \\
\hline $1 \mathrm{H}-2,5$ & 1.55 & & & & \\
\hline $1 \mathrm{H}-2,10$ & 1.60 & & & & \\
\hline $1 \mathrm{H}-2,15$ & 1.65 & 56 & 339.9 & & 0.01327 \\
\hline $1 \mathrm{H}-2,20$ & 1.70 & 59 & 339.2 & & 0.011942 \\
\hline $1 \mathrm{H}-2,25$ & 1.75 & 56.6 & 341.2 & & 0.013496 \\
\hline $1 \mathrm{H}-2,30$ & 1.80 & 54 & 343.5 & & 0.016074 \\
\hline $1 \mathrm{H}-2,35$ & 1.85 & 51 & 341.1 & & 0.019188 \\
\hline $1 \mathrm{H}-2,40$ & 1.90 & 53.3 & 342.2 & & 0.01895 \\
\hline $1 \mathrm{H}-2,45$ & 1.95 & 55.2 & 341.9 & & 0.018191 \\
\hline $1 \mathrm{H}-2,50$ & 2.00 & 54 & 340.6 & & 0.018636 \\
\hline $1 \mathrm{H}-2,55$ & 2.05 & 52 & 337.5 & & 0.019953 \\
\hline $1 \mathrm{H}-2,60$ & 2.10 & 52.4 & 337 & & 0.019899 \\
\hline $1 \mathrm{H}-2,65$ & 2.15 & 50.7 & 339.1 & & 0.02074 \\
\hline $1 \mathrm{H}-2,70$ & 2.20 & 49.9 & 343.2 & & 0.021003 \\
\hline $1 \mathrm{H}-2,75$ & 2.25 & 51.3 & 341 & & 0.019459 \\
\hline $1 \mathrm{H}-2,80$ & 2.30 & 52.4 & 335.2 & & 0.018053 \\
\hline $1 \mathrm{H}-2,85$ & 2.35 & 51 & 334.7 & & 0.01819 \\
\hline $1 \mathrm{H}-2,90$ & 2.40 & 50.3 & 335.9 & & 0.019415 \\
\hline $1 \mathrm{H}-2,95$ & 2.45 & 51.9 & 337.4 & & 0.019392 \\
\hline $1 \mathrm{H}-2,100$ & 2.50 & 51.9 & 336.1 & & 0.01998 \\
\hline $1 \mathrm{H}-2,105$ & 2.55 & 51.7 & 333.7 & & 0.020435 \\
\hline $1 \mathrm{H}-2,110$ & 2.60 & 52.9 & 335 & & 0.020544 \\
\hline $1 \mathrm{H}-2,115$ & 2.65 & 55.4 & 337.5 & & 0.021188 \\
\hline $1 \mathrm{H}-2,120$ & 2.70 & 55.4 & 335.2 & & 0.022868 \\
\hline
\end{tabular}

Blank cells indicate depth levels where data were either not available (i.e., Flexlt-corrected declination data for nonoriented cores) or removed because of disturbance, voids, or measurement edge effects. Only a portion of this table appears here. The complete table is available in ASCII. 
Table T16. NRM inclination, declination, and intensity data after $20 \mathrm{mT}$ peak field AF demagnetization, Hole U1389B. (Continued on next two pages.)

\begin{tabular}{|c|c|c|c|c|c|}
\hline $\begin{array}{l}\text { Core, section, } \\
\text { interval }(\mathrm{cm})\end{array}$ & $\begin{array}{l}\text { Depth } \\
\text { (mbsf) }\end{array}$ & $\begin{array}{c}\text { Inclination } \\
\left(^{\circ}\right)\end{array}$ & $\begin{array}{l}\text { Declination } \\
\left({ }^{\circ}\right)\end{array}$ & $\begin{array}{c}\text { Flexlt- } \\
\text { corrected } \\
\text { declination } \\
\left({ }^{\circ}\right)\end{array}$ & $\begin{array}{l}\text { Intensity } \\
(\mathrm{A} / \mathrm{m})\end{array}$ \\
\hline \multicolumn{6}{|l|}{ 339-U1389B- } \\
\hline $1 \mathrm{H}-1$ & 0.00 & & & & \\
\hline $1 \mathrm{H}-1,5$ & 0.05 & & & & \\
\hline $1 \mathrm{H}-1,10$ & 0.10 & & & & \\
\hline $1 \mathrm{H}-1,15$ & 0.15 & 84 & 255.4 & & 0.021805 \\
\hline $1 \mathrm{H}-1,20$ & 0.20 & 80.4 & 236.7 & & 0.02244 \\
\hline $1 \mathrm{H}-1,25$ & 0.25 & 72.5 & 228.9 & & 0.025018 \\
\hline $1 \mathrm{H}-1,30$ & 0.30 & 68.6 & 223.5 & & 0.025794 \\
\hline $1 \mathrm{H}-1,35$ & 0.35 & 66.9 & 223.5 & & 0.02445 \\
\hline $1 \mathrm{H}-1,40$ & 0.40 & 65.2 & 224.8 & & 0.02264 \\
\hline $1 \mathrm{H}-1,45$ & 0.45 & 63.3 & 229.3 & & 0.021124 \\
\hline $1 \mathrm{H}-1,50$ & 0.50 & 66.2 & 229.2 & & 0.019393 \\
\hline $1 \mathrm{H}-1,55$ & 0.55 & 67.8 & 227.3 & & 0.018569 \\
\hline $1 \mathrm{H}-1,60$ & 0.60 & 65.6 & 229.4 & & 0.019036 \\
\hline $1 \mathrm{H}-1,65$ & 0.65 & 60.9 & 229.3 & & 0.020262 \\
\hline $1 \mathrm{H}-1,70$ & 0.70 & 59.5 & 228.6 & & 0.019667 \\
\hline $1 \mathrm{H}-1,75$ & 0.75 & 60.7 & 225.2 & & 0.018475 \\
\hline $1 \mathrm{H}-1,80$ & 0.80 & 60.5 & 226.1 & & 0.017501 \\
\hline $1 \mathrm{H}-1,85$ & 0.85 & 60 & 226.5 & & 0.017734 \\
\hline $1 \mathrm{H}-1,90$ & 0.90 & 59.9 & 226.6 & & 0.01794 \\
\hline $1 \mathrm{H}-1,95$ & 0.95 & 58.5 & 228.7 & & 0.019173 \\
\hline $1 \mathrm{H}-1,100$ & 1.00 & 55.8 & 228.7 & & 0.020077 \\
\hline $1 \mathrm{H}-1,105$ & 1.05 & 54.7 & 227.3 & & 0.019385 \\
\hline $1 \mathrm{H}-1,110$ & 1.10 & 54.2 & 224.2 & & 0.018428 \\
\hline $1 \mathrm{H}-1,115$ & 1.15 & 53.9 & 224.5 & & 0.018146 \\
\hline $1 \mathrm{H}-1,120$ & 1.20 & 54.3 & 225.5 & & 0.018802 \\
\hline $1 \mathrm{H}-1,125$ & 1.25 & 53.2 & 227.8 & & 0.020373 \\
\hline $1 \mathrm{H}-1,130$ & 1.30 & 53.3 & 227.3 & & 0.020745 \\
\hline $1 \mathrm{H}-1,135$ & 1.35 & 53.1 & 225.4 & & 0.02072 \\
\hline $1 \mathrm{H}-1,140$ & 1.40 & & & & \\
\hline $1 \mathrm{H}-1,145$ & 1.45 & & & & \\
\hline $1 \mathrm{H}-1,150$ & 1.50 & & & & \\
\hline $1 \mathrm{H}-2$ & 1.50 & & & & \\
\hline $1 \mathrm{H}-2,5$ & 1.55 & & & & \\
\hline $1 \mathrm{H}-2,10$ & 1.60 & & & & \\
\hline $1 \mathrm{H}-2,15$ & 1.65 & 59.3 & 240.2 & & 0.026734 \\
\hline $1 \mathrm{H}-2,20$ & 1.70 & 58.9 & 239.6 & & 0.027541 \\
\hline $1 \mathrm{H}-2,25$ & 1.75 & 57.4 & 237.3 & & 0.028692 \\
\hline $1 \mathrm{H}-2,30$ & 1.80 & 56.6 & 237.3 & & 0.028024 \\
\hline $1 \mathrm{H}-2,35$ & 1.85 & 54.1 & 237.7 & & 0.0271 \\
\hline $1 \mathrm{H}-2,40$ & 1.90 & 52.2 & 235.4 & & 0.026294 \\
\hline $1 \mathrm{H}-2,45$ & 1.95 & 50.5 & 232.5 & & 0.025544 \\
\hline $1 \mathrm{H}-2,50$ & 2.00 & 50.7 & 229.7 & & 0.024056 \\
\hline $1 \mathrm{H}-2,55$ & 2.05 & 52.2 & 227.3 & & 0.022529 \\
\hline $1 \mathrm{H}-2,60$ & 2.10 & 51 & 229.8 & & 0.024276 \\
\hline $1 \mathrm{H}-2,65$ & 2.15 & 51.5 & 229.3 & & 0.026217 \\
\hline $1 \mathrm{H}-2,70$ & 2.20 & 52.9 & 231.1 & & 0.026749 \\
\hline $1 \mathrm{H}-2,75$ & 2.25 & 49.8 & 238 & & 0.026206 \\
\hline $1 \mathrm{H}-2,80$ & 2.30 & 51.4 & 237.6 & & 0.024487 \\
\hline $1 \mathrm{H}-2,85$ & 2.35 & 51.5 & 236.5 & & 0.023073 \\
\hline $1 \mathrm{H}-2,90$ & 2.40 & 51.9 & 236.7 & & 0.022244 \\
\hline $1 \mathrm{H}-2,95$ & 2.45 & 52.2 & 236.3 & & 0.022751 \\
\hline $1 \mathrm{H}-2,100$ & 2.50 & 52.7 & 235.8 & & 0.023312 \\
\hline $1 \mathrm{H}-2,105$ & 2.55 & 52.9 & 236.8 & & 0.023679 \\
\hline $1 \mathrm{H}-2,110$ & 2.60 & 52.6 & 238.6 & & 0.024128 \\
\hline $1 \mathrm{H}-2,115$ & 2.65 & 51.6 & 240.2 & & 0.024782 \\
\hline $1 \mathrm{H}-2,120$ & 2.70 & 51.4 & 240 & & 0.025265 \\
\hline $1 \mathrm{H}-2,125$ & 2.75 & 51.6 & 239.6 & & 0.025263 \\
\hline $1 \mathrm{H}-2,130$ & 2.80 & 51.2 & 238.9 & & 0.024668 \\
\hline $1 \mathrm{H}-2,135$ & 2.85 & 50.3 & 239.1 & & 0.023733 \\
\hline $1 \mathrm{H}-2,140$ & 2.90 & & & & \\
\hline $1 \mathrm{H}-2,145$ & 2.95 & & & & \\
\hline $1 \mathrm{H}-2,150$ & 3.00 & & & & \\
\hline $1 \mathrm{H}-3$ & 3.00 & & & & \\
\hline $1 \mathrm{H}-3,5$ & 3.05 & & & & \\
\hline $1 \mathrm{H}-3,10$ & 3.10 & & & & \\
\hline
\end{tabular}


Table T16 (continued). (Continued on next page.)

\begin{tabular}{|c|c|c|c|c|c|}
\hline $\begin{array}{l}\text { Core, section, } \\
\text { interval }(\mathrm{cm})\end{array}$ & $\begin{array}{l}\text { Depth } \\
\text { (mbsf) }\end{array}$ & $\begin{array}{c}\text { Inclination } \\
\left(^{\circ}\right)\end{array}$ & $\begin{array}{l}\text { Declination } \\
\left({ }^{\circ}\right)\end{array}$ & $\begin{array}{c}\text { Flexlt- } \\
\text { corrected } \\
\text { declination } \\
\left(^{\circ}\right)\end{array}$ & $\begin{array}{l}\text { Intensity } \\
(\mathrm{A} / \mathrm{m})\end{array}$ \\
\hline $1 \mathrm{H}-3,15$ & 3.15 & 60.6 & 223.2 & & 0.016309 \\
\hline $1 \mathrm{H}-3,20$ & 3.20 & 62.1 & 225.5 & & 0.015047 \\
\hline $1 \mathrm{H}-3,25$ & 3.25 & 62.5 & 221.2 & & 0.014073 \\
\hline $1 \mathrm{H}-3,30$ & 3.30 & 63 & 223.6 & & 0.013859 \\
\hline $1 \mathrm{H}-3,35$ & 3.35 & 60.9 & 225.9 & & 0.014273 \\
\hline $1 \mathrm{H}-3,40$ & 3.40 & 58.6 & 222.3 & & 0.013952 \\
\hline $1 \mathrm{H}-3,45$ & 3.45 & 51.7 & 220.9 & & 0.012306 \\
\hline $1 \mathrm{H}-3,50$ & 3.50 & 44.6 & 223.8 & & 0.008185 \\
\hline $1 \mathrm{H}-3,55$ & 3.55 & 51.7 & 211.6 & & 0.004438 \\
\hline $1 \mathrm{H}-3,60$ & 3.60 & 47.8 & 177.7 & & 0.0036 \\
\hline $1 \mathrm{H}-3,65$ & 3.65 & 48.1 & 185.8 & & 0.003682 \\
\hline $1 \mathrm{H}-3,70$ & 3.70 & 46 & 191.1 & & 0.004145 \\
\hline $1 \mathrm{H}-3,75$ & 3.75 & 45.5 & 192.1 & & 0.004338 \\
\hline $1 \mathrm{H}-3,80$ & 3.80 & 46 & 192.3 & & 0.004275 \\
\hline $1 \mathrm{H}-3,85$ & 3.85 & 49.1 & 196.5 & & 0.004928 \\
\hline $1 \mathrm{H}-3,90$ & 3.90 & 47.9 & 200.4 & & 0.005396 \\
\hline $1 \mathrm{H}-3,95$ & 3.95 & 46.8 & 198.9 & & 0.006012 \\
\hline $1 \mathrm{H}-3,100$ & 4.00 & 51.5 & 200.4 & & 0.008032 \\
\hline $1 \mathrm{H}-3,105$ & 4.05 & 53.3 & 220.5 & & 0.012352 \\
\hline $1 \mathrm{H}-3,110$ & 4.10 & 53.7 & 218.7 & & 0.013108 \\
\hline $1 \mathrm{H}-3,115$ & 4.15 & 55.4 & 209.5 & & 0.011064 \\
\hline $1 \mathrm{H}-3,120$ & 4.20 & 56.5 & 202.8 & & 0.010778 \\
\hline $1 \mathrm{H}-3,125$ & 4.25 & 55.5 & 202.4 & & 0.012366 \\
\hline $1 \mathrm{H}-3,130$ & 4.30 & 56 & 201.8 & & 0.013025 \\
\hline $1 \mathrm{H}-3,135$ & 4.35 & 57.2 & 204.3 & & 0.014821 \\
\hline $1 \mathrm{H}-3,140$ & 4.40 & & & & \\
\hline $1 \mathrm{H}-3,145$ & 4.45 & & & & \\
\hline $1 \mathrm{H}-3,150$ & 4.50 & & & & \\
\hline $1 \mathrm{H}-4$ & 4.50 & & & & \\
\hline $1 \mathrm{H}-4,5$ & 4.55 & & & & \\
\hline $1 \mathrm{H}-4,10$ & 4.60 & & & & \\
\hline $1 \mathrm{H}-4,15$ & 4.65 & 54 & 209.9 & & 0.016011 \\
\hline $1 \mathrm{H}-4,20$ & 4.70 & 55.2 & 211.6 & & 0.016529 \\
\hline $1 \mathrm{H}-4,25$ & 4.75 & 54.7 & 210.9 & & 0.016989 \\
\hline $1 \mathrm{H}-4,30$ & 4.80 & 54.3 & 210.5 & & 0.016729 \\
\hline $1 \mathrm{H}-4,35$ & 4.85 & 54.9 & 208.7 & & 0.015231 \\
\hline $1 \mathrm{H}-4,40$ & 4.90 & 55.5 & 204.6 & & 0.014678 \\
\hline $1 \mathrm{H}-4,45$ & 4.95 & 55.4 & 206.8 & & 0.015344 \\
\hline $1 \mathrm{H}-4,50$ & 5.00 & 54.8 & 205.9 & & 0.016216 \\
\hline $1 \mathrm{H}-4,55$ & 5.05 & 54.5 & 202.5 & & 0.016737 \\
\hline $1 \mathrm{H}-4,60$ & 5.10 & 54.3 & 204 & & 0.017059 \\
\hline $1 \mathrm{H}-4,65$ & 5.15 & 54.6 & 208.5 & & 0.016933 \\
\hline $1 \mathrm{H}-4,70$ & 5.20 & 56.8 & 209.4 & & 0.017149 \\
\hline $1 \mathrm{H}-4,75$ & 5.25 & 56.5 & 209.7 & & 0.017634 \\
\hline $1 \mathrm{H}-4,80$ & 5.30 & 56.8 & 209.3 & & 0.018219 \\
\hline $1 \mathrm{H}-4,85$ & 5.35 & 57.2 & 208.3 & & 0.018503 \\
\hline $1 \mathrm{H}-4,90$ & 5.40 & 56.2 & 207.5 & & 0.018101 \\
\hline $1 \mathrm{H}-4,95$ & 5.45 & 54.9 & 205.6 & & 0.01685 \\
\hline $1 \mathrm{H}-4,100$ & 5.50 & 53.9 & 204.3 & & 0.015405 \\
\hline $1 \mathrm{H}-4,105$ & 5.55 & 53.6 & 203.1 & & 0.014778 \\
\hline $1 \mathrm{H}-4,110$ & 5.60 & 51.4 & 202.2 & & 0.01448 \\
\hline $1 \mathrm{H}-4,115$ & 5.65 & 46.2 & 201.2 & & 0.014512 \\
\hline $1 \mathrm{H}-4,120$ & 5.70 & 38.9 & 199.3 & & 0.01484 \\
\hline $1 \mathrm{H}-4,125$ & 5.75 & 31.2 & 200 & & 0.013762 \\
\hline $1 \mathrm{H}-4,130$ & 5.80 & 26 & 204.8 & & 0.01249 \\
\hline $1 \mathrm{H}-4,135$ & 5.85 & 22.6 & 207.8 & & 0.010417 \\
\hline $1 \mathrm{H}-4,140$ & 5.90 & & & & \\
\hline $1 \mathrm{H}-4,145$ & 5.95 & & & & \\
\hline $1 \mathrm{H}-4,150$ & 6.00 & & & & \\
\hline $1 \mathrm{H}-5$ & 6.00 & & & & \\
\hline $1 \mathrm{H}-5,5$ & 6.05 & & & & \\
\hline $1 \mathrm{H}-5,10$ & 6.10 & & & & \\
\hline $1 \mathrm{H}-5,15$ & 6.15 & 52.8 & 220.4 & & 0.012875 \\
\hline $1 \mathrm{H}-5,20$ & 6.20 & 56 & 223.1 & & 0.009995 \\
\hline $1 \mathrm{H}-5,25$ & 6.25 & 55.8 & 225.2 & & 0.009384 \\
\hline $1 \mathrm{H}-5,30$ & 6.30 & 55.7 & 227.4 & & 0.009678 \\
\hline $1 \mathrm{H}-5,35$ & 6.35 & 57.6 & 225.3 & & 0.010069 \\
\hline
\end{tabular}


Table T16 (continued).

\begin{tabular}{|c|c|c|c|c|c|}
\hline $\begin{array}{l}\text { Core, section, } \\
\text { interval }(\mathrm{cm})\end{array}$ & $\begin{array}{l}\text { Depth } \\
\text { (mbsf) }\end{array}$ & $\begin{array}{c}\text { Inclination } \\
\left({ }^{\circ}\right)\end{array}$ & $\begin{array}{l}\text { Declination } \\
\left({ }^{\circ}\right)\end{array}$ & $\begin{array}{c}\text { Flexlt- } \\
\text { corrected } \\
\text { declination } \\
\left(^{\circ}\right)\end{array}$ & $\begin{array}{l}\text { Intensity } \\
(\mathrm{A} / \mathrm{m})\end{array}$ \\
\hline $1 \mathrm{H}-5,40$ & 6.40 & 57.2 & 225.1 & & 0.010825 \\
\hline $1 \mathrm{H}-5,45$ & 6.45 & 56.1 & 226.5 & & 0.011627 \\
\hline $1 \mathrm{H}-5,50$ & 6.50 & 54.4 & 219.3 & & 0.012495 \\
\hline $1 \mathrm{H}-5,55$ & 6.55 & 55.9 & 218.9 & & 0.012086 \\
\hline $1 \mathrm{H}-5,60$ & 6.60 & 59.7 & 224.9 & & 0.01146 \\
\hline $1 \mathrm{H}-5,65$ & 6.65 & 62.5 & 226.1 & & 0.011832 \\
\hline $1 \mathrm{H}-5,70$ & 6.70 & 62 & 223.9 & & 0.012775 \\
\hline $1 \mathrm{H}-5,75$ & 6.75 & 60.8 & 221.5 & & 0.013304 \\
\hline $1 \mathrm{H}-5,80$ & 6.80 & 61.2 & 221.8 & & 0.01357 \\
\hline $1 \mathrm{H}-5,85$ & 6.85 & 63.7 & 224.4 & & 0.013255 \\
\hline $1 \mathrm{H}-5,90$ & 6.90 & 67.2 & 225 & & 0.012337 \\
\hline $1 \mathrm{H}-5,95$ & 6.95 & 66.3 & 220.7 & & 0.012294 \\
\hline $1 \mathrm{H}-5,100$ & 7.00 & 64.1 & 219.9 & & 0.012505 \\
\hline $1 \mathrm{H}-5,105$ & 7.05 & 62.1 & 219.8 & & 0.012822 \\
\hline $1 \mathrm{H}-5,110$ & 7.10 & 62.9 & 221 & & 0.01326 \\
\hline $1 \mathrm{H}-5,115$ & 7.15 & 64 & 220 & & 0.014191 \\
\hline $1 \mathrm{H}-5,120$ & 7.20 & 62 & 215.2 & & 0.015039 \\
\hline $1 \mathrm{H}-5,125$ & 7.25 & 62.1 & 212.3 & & 0.014472 \\
\hline $1 \mathrm{H}-5,130$ & 7.30 & 64.3 & 218.8 & & 0.013813 \\
\hline $1 \mathrm{H}-5,135$ & 7.35 & 63.9 & 223.7 & & 0.013752 \\
\hline $1 \mathrm{H}-5,140$ & 7.40 & & & & \\
\hline $1 \mathrm{H}-5,145$ & 7.45 & & & & \\
\hline $1 \mathrm{H}-5,150$ & 7.50 & & & & \\
\hline $1 \mathrm{H}-6$ & 7.50 & & & & \\
\hline $1 \mathrm{H}-6,5$ & 7.55 & & & & \\
\hline $1 \mathrm{H}-6,10$ & 7.6 & & & & \\
\hline $1 \mathrm{H}-6,15$ & 7.65 & 58 & 216.3 & & 0.01458 \\
\hline $1 \mathrm{H}-6,20$ & 7.70 & 58.6 & 214.1 & & 0.013933 \\
\hline $1 \mathrm{H}-6,25$ & 7.75 & 59.4 & 214.7 & & 0.013072 \\
\hline $1 \mathrm{H}-6,30$ & 7.80 & 60 & 216.3 & & 0.012743 \\
\hline $1 \mathrm{H}-6,35$ & 7.85 & 58.2 & 216.1 & & 0.012984 \\
\hline $1 \mathrm{H}-6,40$ & 7.90 & 58 & 213.8 & & 0.013162 \\
\hline $1 \mathrm{H}-6,45$ & 7.95 & 57.9 & 216.2 & & 0.014979 \\
\hline $1 \mathrm{H}-6,50$ & 8.00 & 58.2 & 217.5 & & 0.016207 \\
\hline $1 \mathrm{H}-6,55$ & 8.05 & 58.4 & 217.8 & & 0.016028 \\
\hline $1 \mathrm{H}-6,60$ & 8.10 & 57.9 & 217.3 & & 0.015385 \\
\hline $1 \mathrm{H}-6,65$ & 8.15 & 55.7 & 219.5 & & 0.015424 \\
\hline $1 \mathrm{H}-6,70$ & 8.20 & 54.1 & 217.1 & & 0.01459 \\
\hline $1 \mathrm{H}-6,75$ & 8.25 & 52.2 & 215.5 & & 0.01354 \\
\hline $1 \mathrm{H}-6,80$ & 8.30 & 52.9 & 212.1 & & 0.012695 \\
\hline $1 \mathrm{H}-6,85$ & 8.35 & 54.1 & 211.8 & & 0.012436 \\
\hline $1 \mathrm{H}-6,90$ & 8.40 & 53.8 & 212.3 & & 0.012629 \\
\hline $1 \mathrm{H}-6,95$ & 8.45 & 52.9 & 214.3 & & 0.012884 \\
\hline $1 \mathrm{H}-6,100$ & 8.50 & 52.7 & 213.7 & & 0.013115 \\
\hline $1 \mathrm{H}-6,105$ & 8.55 & 52.7 & 210 & & 0.012571 \\
\hline $1 \mathrm{H}-6,110$ & 8.60 & 51.3 & 212.2 & & 0.012253 \\
\hline $1 \mathrm{H}-6,115$ & 8.65 & 51.3 & 214.3 & & 0.011934 \\
\hline $1 \mathrm{H}-6,120$ & 8.70 & 51.6 & 214.2 & & 0.012043 \\
\hline $1 \mathrm{H}-6,125$ & 8.75 & 49.6 & 214.5 & & 0.012496 \\
\hline $1 \mathrm{H}-6,130$ & 8.80 & & & & \\
\hline $1 \mathrm{H}-6,135$ & 8.85 & & & & \\
\hline $1 \mathrm{H}-6,140$ & 8.90 & & & & \\
\hline $1 \mathrm{H}-7$ & 8.90 & & & & \\
\hline $1 \mathrm{H}-7,5$ & 8.95 & & & & \\
\hline $1 \mathrm{H}-7,10$ & 9.00 & & & & \\
\hline $1 \mathrm{H}-7,15$ & 9.05 & 52 & 220 & & 0.011534 \\
\hline $1 \mathrm{H}-7,20$ & 9.10 & 46.9 & 219 & & 0.010985 \\
\hline $1 \mathrm{H}-7,25$ & 9.15 & 48.5 & 222.8 & & 0.010876 \\
\hline $1 \mathrm{H}-7,30$ & 9.20 & 50.5 & 221.5 & & 0.010934 \\
\hline $1 \mathrm{H}-7,35$ & 9.25 & 47.3 & 213.9 & & 0.011279 \\
\hline $1 \mathrm{H}-7,40$ & 9.30 & 34.5 & 219.3 & & 0.014088 \\
\hline $1 \mathrm{H}-7,45$ & 9.35 & & & & \\
\hline $1 \mathrm{H}-7,50$ & 9.40 & & & & \\
\hline $1 \mathrm{H}-7,55$ & 9.45 & & & & \\
\hline
\end{tabular}

Blank cells indicate depth levels where data were either not available (i.e., Flexlt-corrected declination data for nonoriented cores) or removed because of disturbance, voids, or measurement edge effects. 
Table T17. NRM inclination, declination, and intensity data after $20 \mathrm{mT}$ peak field AF demagnetization, Hole U1389C.

\begin{tabular}{|c|c|c|c|c|c|}
\hline $\begin{array}{l}\text { Core, section, } \\
\text { interval }(\mathrm{cm})\end{array}$ & $\begin{array}{l}\text { Depth } \\
\text { (mbsf) }\end{array}$ & $\begin{array}{c}\text { Inclination } \\
\left({ }^{\circ}\right)\end{array}$ & $\begin{array}{l}\text { Declination } \\
\left({ }^{\circ}\right)\end{array}$ & $\begin{array}{c}\text { Flexlt- } \\
\text { corrected } \\
\text { declination } \\
\left({ }^{\circ}\right)\end{array}$ & $\begin{array}{l}\text { Intensity } \\
(\mathrm{A} / \mathrm{m})\end{array}$ \\
\hline \multicolumn{6}{|l|}{ 339-U1389C- } \\
\hline $1 \mathrm{H}-1$ & 0.00 & & & & \\
\hline $1 \mathrm{H}-1,5$ & 0.05 & & & & \\
\hline $1 \mathrm{H}-1,10$ & 0.10 & & & & \\
\hline $1 \mathrm{H}-1,15$ & 0.15 & 43.2 & 57.4 & & 0.008747 \\
\hline $1 \mathrm{H}-1,20$ & 0.20 & 64.4 & 69.9 & & 0.013462 \\
\hline $1 \mathrm{H}-1,25$ & 0.25 & 77.9 & 68.5 & & 0.014681 \\
\hline $1 \mathrm{H}-1,30$ & 0.30 & 78.3 & 61.5 & & 0.014979 \\
\hline $1 \mathrm{H}-1,35$ & 0.35 & 79.6 & 76.1 & & 0.012954 \\
\hline $1 \mathrm{H}-1,40$ & 0.40 & 76.2 & 99.9 & & 0.009941 \\
\hline $1 \mathrm{H}-1,45$ & 0.45 & 76.1 & 109.2 & & 0.007651 \\
\hline $1 \mathrm{H}-1,50$ & 0.50 & 78.9 & 94 & & 0.007495 \\
\hline $1 \mathrm{H}-1,55$ & 0.55 & 74 & 83.7 & & 0.007937 \\
\hline $1 \mathrm{H}-1,60$ & 0.60 & 72.6 & 82.7 & & 0.007204 \\
\hline $1 \mathrm{H}-1,65$ & 0.65 & 74.1 & 73.6 & & 0.007257 \\
\hline $1 \mathrm{H}-1,70$ & 0.70 & 68.9 & 42.9 & & 0.008807 \\
\hline $1 \mathrm{H}-1,75$ & 0.75 & 67.6 & 38.4 & & 0.009526 \\
\hline $1 \mathrm{H}-1,80$ & 0.80 & 66.5 & 45.3 & & 0.010225 \\
\hline $1 \mathrm{H}-1,85$ & 0.85 & 67.4 & 46.5 & & 0.010338 \\
\hline $1 \mathrm{H}-1,90$ & 0.90 & 72.9 & 42.1 & & 0.009268 \\
\hline $1 \mathrm{H}-1,95$ & 0.95 & 70.6 & 50.4 & & 0.009551 \\
\hline $1 \mathrm{H}-1,100$ & 1.00 & 69.2 & 51 & & 0.010594 \\
\hline $1 \mathrm{H}-1,105$ & 1.05 & 62.9 & 58.7 & & 0.01149 \\
\hline $1 \mathrm{H}-1,110$ & 1.10 & 60.4 & 50.2 & & 0.011795 \\
\hline $1 \mathrm{H}-1,115$ & 1.15 & 59 & 44.4 & & 0.012553 \\
\hline $1 \mathrm{H}-1,120$ & 1.20 & 58.8 & 45.1 & & 0.012827 \\
\hline $1 \mathrm{H}-1,125$ & 1.25 & 58.2 & 46.4 & & 0.012879 \\
\hline $1 \mathrm{H}-1,130$ & 1.30 & 56.2 & 42.1 & & 0.013233 \\
\hline $1 \mathrm{H}-1,135$ & 1.35 & 53.9 & 39.8 & & 0.013881 \\
\hline $1 \mathrm{H}-1,140$ & 1.40 & & & & \\
\hline $1 \mathrm{H}-1,145$ & 1.45 & & & & \\
\hline $1 \mathrm{H}-1,150$ & 1.50 & & & & \\
\hline $1 \mathrm{H}-2$ & 1.50 & & & & \\
\hline $1 \mathrm{H}-2,5$ & 1.55 & & & & \\
\hline $1 \mathrm{H}-2,10$ & 1.60 & & & & \\
\hline $1 \mathrm{H}-2,15$ & 1.65 & 52.6 & 47.7 & & 0.010307 \\
\hline $1 \mathrm{H}-2,20$ & 1.70 & 50.5 & 43.4 & & 0.012119 \\
\hline $1 \mathrm{H}-2,25$ & 1.75 & 49.6 & 39.8 & & 0.012548 \\
\hline $1 \mathrm{H}-2,30$ & 1.80 & 51 & 40.3 & & 0.012188 \\
\hline $1 \mathrm{H}-2,35$ & 1.85 & 51.3 & 42 & & 0.011691 \\
\hline $1 \mathrm{H}-2,40$ & 1.90 & 48.9 & 42.9 & & 0.011752 \\
\hline $1 \mathrm{H}-2,45$ & 1.95 & 46.1 & 40.4 & & 0.011862 \\
\hline $1 \mathrm{H}-2,50$ & 2.00 & 46.9 & 38.7 & & 0.011296 \\
\hline $1 \mathrm{H}-2,55$ & 2.05 & 50.4 & 43.3 & & 0.010025 \\
\hline $1 \mathrm{H}-2,60$ & 2.10 & 51.1 & 48.4 & & 0.009626 \\
\hline $1 \mathrm{H}-2,65$ & 2.15 & 50.3 & 47.8 & & 0.010278 \\
\hline $1 \mathrm{H}-2,70$ & 2.20 & 48.3 & 45 & & 0.011857 \\
\hline $1 \mathrm{H}-2,75$ & 2.25 & 46.7 & 43.4 & & 0.013209 \\
\hline $1 \mathrm{H}-2,80$ & 2.30 & 47.5 & 47.2 & & 0.012659 \\
\hline $1 \mathrm{H}-2,85$ & 2.35 & 47.2 & 43.4 & & 0.012401 \\
\hline $1 \mathrm{H}-2,90$ & 2.40 & 45.7 & 41.7 & & 0.012593 \\
\hline $1 \mathrm{H}-2,95$ & 2.45 & 44.4 & 43.3 & & 0.012145 \\
\hline $1 \mathrm{H}-2,100$ & 2.50 & 43.3 & 41.4 & & 0.01202 \\
\hline $1 \mathrm{H}-2,105$ & 2.55 & 41.2 & 40.8 & & 0.012462 \\
\hline $1 \mathrm{H}-2,110$ & 2.60 & 41.6 & 45.7 & & 0.013122 \\
\hline $1 \mathrm{H}-2,115$ & 2.65 & 43.8 & 46 & & 0.014263 \\
\hline $1 \mathrm{H}-2,120$ & 2.70 & 44.3 & 44.8 & & 0.014729 \\
\hline $1 \mathrm{H}-2,125$ & 2.75 & 46 & 42.4 & & 0.014207 \\
\hline
\end{tabular}

Blank cells indicate depth levels where data were either not available (i.e., Flexlt-corrected declination data for nonoriented cores) or removed because of disturbance, voids, or measurement edge effects. Only a portion of this table appears here. The complete table is available in ASCII. 
Table T18. NRM inclination, declination, and intensity data after $20 \mathrm{mT}$ peak field AF demagnetization, Hole U1389D.

\begin{tabular}{|c|c|c|c|c|c|}
\hline $\begin{array}{l}\text { Core, section, } \\
\text { interval (cm) }\end{array}$ & $\begin{array}{l}\text { Depth } \\
\text { (mbsf) }\end{array}$ & $\begin{array}{c}\text { Inclination } \\
\left({ }^{\circ}\right)\end{array}$ & $\begin{array}{c}\text { Declination } \\
\left(^{\circ}\right)\end{array}$ & $\begin{array}{c}\text { Flexlt- } \\
\text { corrected } \\
\text { declination } \\
\left({ }^{\circ}\right)\end{array}$ & $\begin{array}{l}\text { Intensity } \\
(\mathrm{A} / \mathrm{m})\end{array}$ \\
\hline \multicolumn{6}{|l|}{ 339-U1389D- } \\
\hline $1 \mathrm{H}-1$ & 0.00 & & & & \\
\hline $1 \mathrm{H}-1,5$ & 0.05 & & & & \\
\hline $1 \mathrm{H}-1,10$ & 0.10 & & & & \\
\hline $1 \mathrm{H}-1,15$ & 0.15 & 54.3 & 247.7 & & 0.007386 \\
\hline $1 \mathrm{H}-1,20$ & 0.20 & 57.3 & 250.7 & & 0.008479 \\
\hline $1 \mathrm{H}-1,25$ & 0.25 & 56.3 & 263.2 & & 0.008952 \\
\hline $1 \mathrm{H}-1,30$ & 0.30 & 54.2 & 272 & & 0.010233 \\
\hline $1 \mathrm{H}-1,35$ & 0.35 & 52.1 & 270.6 & & 0.010818 \\
\hline $1 \mathrm{H}-1,40$ & 0.40 & 52 & 271 & & 0.010201 \\
\hline $1 \mathrm{H}-1,45$ & 0.45 & 55.3 & 272.6 & & 0.009734 \\
\hline $1 \mathrm{H}-1,50$ & 0.50 & 57.6 & 269.9 & & 0.00921 \\
\hline $1 \mathrm{H}-1,55$ & 0.55 & 54.5 & 280.3 & & 0.010419 \\
\hline $1 \mathrm{H}-1,60$ & 0.60 & 54 & 277.1 & & 0.010488 \\
\hline $1 \mathrm{H}-1,65$ & 0.65 & 54.9 & 274.9 & & 0.009984 \\
\hline $1 \mathrm{H}-1,70$ & 0.70 & 54.4 & 275.2 & & 0.010428 \\
\hline $1 \mathrm{H}-1,75$ & 0.75 & 58.3 & 275.2 & & 0.010728 \\
\hline $1 \mathrm{H}-1,80$ & 0.80 & 59.1 & 280.8 & & 0.012254 \\
\hline $1 \mathrm{H}-1,85$ & 0.85 & 59.5 & 286.1 & & 0.013253 \\
\hline $1 \mathrm{H}-1,90$ & 0.90 & 63.5 & 285.1 & & 0.012802 \\
\hline $1 \mathrm{H}-1,95$ & 0.95 & 63.7 & 281.7 & & 0.012915 \\
\hline $1 \mathrm{H}-1,100$ & 1.00 & 61.7 & 279.4 & & 0.014113 \\
\hline $1 \mathrm{H}-1,105$ & 1.05 & 62.4 & 278.6 & & 0.014626 \\
\hline $1 \mathrm{H}-1,110$ & 1.10 & 64 & 283.9 & & 0.014782 \\
\hline $1 \mathrm{H}-1,115$ & 1.15 & 61.6 & 285.6 & & 0.016353 \\
\hline $1 \mathrm{H}-1,120$ & 1.20 & 58.9 & 282.2 & & 0.017872 \\
\hline $1 \mathrm{H}-1,125$ & 1.25 & 59.5 & 280.1 & & 0.018324 \\
\hline $1 \mathrm{H}-1,130$ & 1.30 & 65.7 & 275.1 & & 0.016475 \\
\hline $1 \mathrm{H}-1,135$ & 1.35 & 64.7 & 274.6 & & 0.015872 \\
\hline $1 \mathrm{H}-1,140$ & 1.40 & & & & \\
\hline $1 \mathrm{H}-1,145$ & 1.45 & & & & \\
\hline $1 \mathrm{H}-1,150$ & 1.50 & & & & \\
\hline $1 \mathrm{H}-2$ & 1.50 & & & & \\
\hline $1 \mathrm{H}-2,5$ & 1.55 & & & & \\
\hline $1 \mathrm{H}-2,10$ & 1.60 & & & & \\
\hline $1 \mathrm{H}-2,15$ & 1.65 & 51.3 & 308.7 & & 0.01421 \\
\hline $1 \mathrm{H}-2,20$ & 1.70 & 50.2 & 307.5 & & 0.012601 \\
\hline $1 \mathrm{H}-2,25$ & 1.75 & 50.2 & 300.3 & & 0.012408 \\
\hline $1 \mathrm{H}-2,30$ & 1.80 & 50.6 & 293.4 & & 0.012578 \\
\hline $1 \mathrm{H}-2,35$ & 1.85 & 51.6 & 293 & & 0.012674 \\
\hline $1 \mathrm{H}-2,40$ & 1.90 & 52.3 & 291.8 & & 0.013283 \\
\hline $1 \mathrm{H}-2,45$ & 1.95 & 56.3 & 287.6 & & 0.013966 \\
\hline $1 \mathrm{H}-2,50$ & 2.00 & 55.2 & 284.1 & & 0.015458 \\
\hline $1 \mathrm{H}-2,55$ & 2.05 & 53.4 & 282.5 & & 0.016854 \\
\hline $1 \mathrm{H}-2,60$ & 2.10 & 53.6 & 278.3 & & 0.017042 \\
\hline $1 \mathrm{H}-2,65$ & 2.15 & 53.7 & 276.3 & & 0.016429 \\
\hline $1 \mathrm{H}-2,70$ & 2.20 & 54.4 & 274.7 & & 0.015893 \\
\hline $1 \mathrm{H}-2,75$ & 2.25 & 53.4 & 277.1 & & 0.016378 \\
\hline $1 \mathrm{H}-2,80$ & 2.30 & 51.2 & 277.6 & & 0.017744 \\
\hline $1 \mathrm{H}-2,85$ & 2.35 & 52.2 & 277 & & 0.017501 \\
\hline $1 \mathrm{H}-2,90$ & 2.40 & 52.3 & 277.6 & & 0.018237 \\
\hline $1 \mathrm{H}-2,95$ & 2.45 & 51.9 & 277 & & 0.019091 \\
\hline $1 \mathrm{H}-2,100$ & 2.50 & 54.6 & 275.5 & & 0.019032 \\
\hline $1 \mathrm{H}-2,105$ & 2.55 & 56.1 & 274.6 & & 0.01911 \\
\hline $1 \mathrm{H}-2,110$ & 2.60 & 57.9 & 274.1 & & 0.018908 \\
\hline $1 \mathrm{H}-2,115$ & 2.65 & 60.5 & 275.5 & & 0.019125 \\
\hline $1 \mathrm{H}-2,120$ & 2.70 & 62.1 & 276.4 & & 0.021392 \\
\hline $1 \mathrm{H}-2,125$ & 2.75 & 60.9 & 274.9 & & 0.024138 \\
\hline
\end{tabular}

Blank cells indicate depth levels where data were either not available (i.e., Flexlt-corrected declination data for nonoriented cores) or removed because of disturbance, voids, or measurement edge effects. Only a portion of this table appears here. The complete table is available in ASCII. 
Table T19. NRM inclination, declination, and intensity data after $20 \mathrm{mT}$ peak field AF demagnetization, Hole U1389E.

\begin{tabular}{|c|c|c|c|c|c|}
\hline $\begin{array}{l}\text { Core, section, } \\
\text { interval }(\mathrm{cm})\end{array}$ & $\begin{array}{l}\text { Depth } \\
\text { (mbsf) }\end{array}$ & $\begin{array}{l}\text { Inclination } \\
\left({ }^{\circ}\right)\end{array}$ & $\begin{array}{c}\text { Declination } \\
\left({ }^{\circ}\right)\end{array}$ & $\begin{array}{c}\text { Flexlt- } \\
\text { corrected } \\
\text { declination } \\
\left({ }^{\circ}\right)\end{array}$ & $\begin{array}{c}\text { Intensity } \\
(A / m)\end{array}$ \\
\hline \multicolumn{6}{|l|}{ 339-U1389E- } \\
\hline $2 \mathrm{R}-1$ & 335.00 & & & & \\
\hline $2 \mathrm{R}-1,5$ & 335.05 & & & & \\
\hline $2 \mathrm{R}-1,10$ & 335.10 & & & & \\
\hline $2 \mathrm{R}-1,15$ & 335.15 & -74.6 & 152.7 & & 0.0007428 \\
\hline $2 \mathrm{R}-1,20$ & 335.20 & -71.8 & 339.8 & & 0.0002173 \\
\hline $2 \mathrm{R}-1,25$ & 335.25 & -77.4 & 268 & & 0.0001768 \\
\hline $2 \mathrm{R}-1,30$ & 335.30 & -58.5 & 149 & & 0.0001204 \\
\hline $2 \mathrm{R}-1,35$ & 335.35 & -38.5 & 142 & & 0.0001353 \\
\hline $2 \mathrm{R}-1,40$ & 335.40 & -40.1 & 139.9 & & 0.000152 \\
\hline $2 \mathrm{R}-1,45$ & 335.45 & -32.9 & 134.6 & & 0.0001039 \\
\hline $2 \mathrm{R}-1,50$ & 335.50 & 14.5 & 116.9 & & $9.29 \mathrm{E}-05$ \\
\hline $2 \mathrm{R}-1,55$ & 335.55 & 20.2 & 104.1 & & $8.32 \mathrm{E}-05$ \\
\hline $2 \mathrm{R}-1,60$ & 335.60 & 35.1 & 136.4 & & $9.58 \mathrm{E}-05$ \\
\hline $2 \mathrm{R}-1,65$ & 335.65 & 16.4 & 156.4 & & $8.23 \mathrm{E}-05$ \\
\hline $2 \mathrm{R}-1,70$ & 335.70 & -1.7 & 208.9 & & 0.0001254 \\
\hline $2 \mathrm{R}-1,75$ & 335.75 & -36.8 & 211.9 & & 0.0001364 \\
\hline $2 \mathrm{R}-1,80$ & 335.80 & & & & \\
\hline $2 \mathrm{R}-1,85$ & 335.85 & & & & \\
\hline $2 \mathrm{R}-1,90$ & 335.90 & & & & \\
\hline $2 \mathrm{R}-1,95$ & 335.95 & & & & \\
\hline $2 \mathrm{R}-1,100$ & 336.00 & & & & \\
\hline $2 \mathrm{R}-1,105$ & 336.05 & 66.9 & 329.3 & & 0.0005136 \\
\hline $2 \mathrm{R}-1,110$ & 336.10 & 68.5 & 27.7 & & 0.00041 \\
\hline $2 \mathrm{R}-1,115$ & 336.15 & 57.4 & 15.3 & & 0.0005401 \\
\hline $2 \mathrm{R}-1,120$ & 336.20 & 76.6 & 75.2 & & 0.0005575 \\
\hline $2 \mathrm{R}-1,125$ & 336.25 & -29.4 & 149.2 & & 0.0009002 \\
\hline $2 \mathrm{R}-1,130$ & 336.30 & & & & \\
\hline $2 \mathrm{R}-1,135$ & 336.35 & & & & \\
\hline $2 \mathrm{R}-1,140$ & 336.40 & & & & \\
\hline $2 \mathrm{R}-2$ & 336.43 & & & & \\
\hline $2 \mathrm{R}-2,5$ & 336.48 & & & & \\
\hline $2 \mathrm{R}-2,10$ & 336.53 & & & & \\
\hline $2 \mathrm{R}-2,15$ & 336.58 & -42.4 & 4.3 & & 0.003994 \\
\hline $2 \mathrm{R}-2,20$ & 336.63 & -37.7 & 345.6 & & 0.002927 \\
\hline $2 \mathrm{R}-2,25$ & 336.68 & 26.6 & 343.1 & & 0.001421 \\
\hline $2 \mathrm{R}-2,30$ & 336.73 & 26.5 & 98.9 & & 0.002376 \\
\hline $2 \mathrm{R}-2,35$ & 336.78 & -26.1 & 76.8 & & 0.002283 \\
\hline $2 \mathrm{R}-2,40$ & 336.83 & -37.6 & 33.6 & & 0.00444 \\
\hline $2 \mathrm{R}-2,45$ & 336.88 & -38 & 32.6 & & 0.004903 \\
\hline $2 \mathrm{R}-2,50$ & 336.93 & -42.8 & 34.4 & & 0.004226 \\
\hline $2 \mathrm{R}-2,55$ & 336.98 & -48.8 & 37.4 & & 0.00426 \\
\hline $2 \mathrm{R}-2,60$ & 337.03 & -43.9 & 43 & & 0.005164 \\
\hline $2 R-2,65$ & 337.08 & -59.9 & 37.5 & & 0.003718 \\
\hline $2 \mathrm{R}-2,70$ & 337.13 & -44.7 & 59.1 & & 0.002987 \\
\hline $2 \mathrm{R}-2,75$ & 337.18 & -35.7 & 41.2 & & 0.002619 \\
\hline $2 \mathrm{R}-2,80$ & 337.23 & & & & \\
\hline $2 \mathrm{R}-2,85$ & 337.28 & & & & \\
\hline $2 \mathrm{R}-2,90$ & 337.33 & & & & \\
\hline $3 R-1$ & 339.50 & & & & \\
\hline $3 R-1,5$ & 339.55 & & & & \\
\hline $3 R-1,10$ & 339.60 & & & & \\
\hline $3 R-1,15$ & 339.65 & -39.5 & 256.6 & & 0.020114 \\
\hline $3 \mathrm{R}-1,20$ & 339.70 & -37.3 & 255.2 & & 0.019172 \\
\hline $3 R-1,25$ & 339.75 & -35.7 & 254.9 & & 0.020913 \\
\hline $3 \mathrm{R}-1,30$ & 339.80 & -44.5 & 251.1 & & 0.012194 \\
\hline $3 R-1,35$ & 339.85 & -53 & 234.7 & & 0.006094 \\
\hline
\end{tabular}

Blank cells indicate depth levels where data were either not available (i.e., Flexlt-corrected declination data for nonoriented cores) or removed because of disturbance, voids, or measurement edge effects. Only a portion of this table appears here. The complete table is available in ASCII. 
Table T20. Polarity boundaries, Site U1389.

\begin{tabular}{|c|c|c|c|c|}
\hline \multirow[b]{2}{*}{ Polarity boundary } & \multirow{2}{*}{$\begin{array}{l}\text { Age } \\
(\mathrm{Ma})\end{array}$} & \multicolumn{3}{|c|}{ Depth (mbsf) } \\
\hline & & Hole U1389A & Hole U1389C & Hole U1389E \\
\hline Brunhes/Matuyama & 0.781 & Above 327.6 & Above 327.2 & \\
\hline T Olduvai & 1.778 & & & 542.0 \\
\hline B Olduvai & 1.945 & & & 592.0 \\
\hline T Reunion & 2.128 & & & 636.4 \\
\hline B Reunion & 2.148 & & & 636.8 \\
\hline Matuyama/Gauss & 2.581 & & & 696.0 \\
\hline T Kaena & 3.032 & & & 757.7 \\
\hline B Kaena & 3.116 & & & 758.3 \\
\hline T Mammoth & 3.207 & & & 858.5 \\
\hline B Mammoth & 3.330 & & & 875.5 \\
\hline Gauss/Gilbert & 3.596 & & & 953.4 \\
\hline
\end{tabular}

Bold $=$ well-defined boundary. $T=$ top,$B=$ bottom .

Table T21. Headspace sample hydrocarbon concentrations, Holes U1389A and U1389E. (Continued on next page.)

\begin{tabular}{|c|c|c|c|c|c|c|c|}
\hline \multirow{2}{*}{$\begin{array}{c}\text { Core, } \\
\text { section }\end{array}$} & \multirow{2}{*}{$\begin{array}{l}\text { Depth } \\
\text { (mbsf) }\end{array}$} & \multicolumn{5}{|c|}{ Concentration (ppmv) } & \multirow[b]{2}{*}{$C_{1} /\left(C_{2}+C_{3}\right.$} \\
\hline & & Methane & Ethene & Ethane & Propene & Propane & \\
\hline \multicolumn{8}{|c|}{ 339-U1389A- } \\
\hline $1 \mathrm{H}-3$ & 3.00 & 106.30 & - & - & - & - & - \\
\hline $2 \mathrm{H}-7$ & 13.32 & $1,021.68$ & - & - & - & - & - \\
\hline $3 \mathrm{H}-7$ & 22.75 & $3,642.55$ & 0.41 & - & - & 0.39 & $4,553.19$ \\
\hline $4 \mathrm{H}-7$ & 32.39 & $18,011.93$ & - & - & - & - & - \\
\hline $5 \mathrm{H}-7$ & 41.97 & $34,520.36$ & - & 0.96 & - & 0.34 & $26,554.12$ \\
\hline $6 \mathrm{H}-7$ & 51.42 & $26,015.53$ & 0.44 & 0.65 & - & 0.71 & $14,453.07$ \\
\hline $7 \mathrm{H}-7$ & 60.60 & $6,435.64$ & - & - & 0.33 & - & $19,501.94$ \\
\hline $8 \mathrm{H}-7$ & 70.39 & $23,949.65$ & - & - & - & - & - \\
\hline $9 \mathrm{H}-7$ & 79.95 & $15,410.33$ & - & 0.53 & - & - & $29,076.09$ \\
\hline $10 \mathrm{H}-7$ & 89.37 & $7,894.85$ & - & - & 0.44 & 0.40 & $9,398.63$ \\
\hline $11 \mathrm{H}-5$ & 95.50 & $17,142.61$ & - & - & - & - & - \\
\hline $12 X-3$ & 100.21 & $71,003.90$ & 1.08 & 1.88 & 0.37 & 0.40 & $19,035.90$ \\
\hline $13 X-5$ & 107.70 & $18,018.58$ & - & 1.23 & - & - & $14,649.25$ \\
\hline $14 X-6$ & 117.67 & $32,071.49$ & - & 1.34 & - & - & $23,933.95$ \\
\hline $15 X-5$ & 126.80 & $31,766.33$ & 0.91 & 1.24 & - & - & $14,775.04$ \\
\hline $16 X-6$ & 136.81 & $14,941.45$ & 0.63 & 0.84 & - & - & $10,164.25$ \\
\hline $17 X-5$ & 145.17 & $7,115.41$ & 0.41 & 0.49 & - & - & 7,906.01 \\
\hline $18 X-5$ & 155.50 & $12,122.29$ & - & 0.51 & 0.44 & 0.33 & $9,470.54$ \\
\hline $19 X-6$ & 165.22 & $7,396.76$ & 0.62 & - & 0.86 & - & $4,997.81$ \\
\hline $20 X-5$ & 173.90 & $5,759.08$ & - & - & 0.30 & - & $19,196.93$ \\
\hline $21 X-6$ & 184.51 & $28,783.86$ & 0.56 & 1.84 & - & - & $11,993.28$ \\
\hline $22 X-5$ & 193.14 & $16,641.53$ & 0.41 & 1.72 & - & - & $7,812.92$ \\
\hline $23 X-5$ & 203.30 & $8,873.00$ & 0.48 & 0.79 & - & - & $6,986.61$ \\
\hline $24 X-4$ & 210.99 & $6,393.55$ & - & 0.79 & - & - & $8,093.10$ \\
\hline $25 X-5$ & 222.10 & $15,838.39$ & 0.58 & 1.58 & - & - & $7,332.59$ \\
\hline $26 X-4$ & 230.70 & $18,867.26$ & 0.91 & 1.89 & - & - & $6,738.31$ \\
\hline $27 X-4$ & 239.64 & $8,027.02$ & 1.18 & 1.60 & - & - & $2,887.42$ \\
\hline $28 X-5$ & 251.30 & $9,609.41$ & 1.08 & 2.40 & - & - & $2,761.32$ \\
\hline $29 X-7$ & 263.50 & $2,184.41$ & - & 0.76 & - & - & $2,874.22$ \\
\hline $30 X-7$ & 272.54 & $3,118.62$ & - & 1.87 & - & - & $1,667.71$ \\
\hline $31 X-6$ & 281.75 & $4,750.98$ & - & 1.96 & - & - & $2,423.97$ \\
\hline $32 X-7$ & 292.31 & $4,685.99$ & - & 1.42 & - & - & $3,299.99$ \\
\hline $33 X-6$ & 300.90 & $6,504.06$ & - & 2.38 & - & - & $2,732.80$ \\
\hline $34 X-7$ & 311.17 & $8,451.35$ & 0.69 & 5.82 & - & - & $1,298.21$ \\
\hline $35 X-3$ & 315.61 & $5,423.46$ & 1.17 & 2.34 & 0.42 & - & $1,380.02$ \\
\hline $35 X-6$ & 319.70 & $2,278.92$ & - & 1.75 & - & - & $1,302.24$ \\
\hline $36 X-2$ & 323.30 & $4,353.27$ & - & 2.77 & - & - & $1,571.58$ \\
\hline $37 X-4$ & 335.66 & $4,843.29$ & - & 4.40 & - & - & $1,100.75$ \\
\hline $38 X-3$ & 344.00 & $6,612.31$ & - & 4.65 & - & - & $1,422.00$ \\
\hline $39 X-1$ & 350.50 & $6,881.96$ & 1.69 & 9.74 & - & - & 602.10 \\
\hline \multicolumn{8}{|l|}{ 339-U1389E- } \\
\hline 4R-3 & 351.80 & $9,685.18$ & 1.66 & 16.35 & - & - & 537.77 \\
\hline $5 R-3$ & 361.40 & $14,550.22$ & 0.47 & 12.60 & - & - & $1,113.25$ \\
\hline
\end{tabular}


Table T21 (continued).

\begin{tabular}{|c|c|c|c|c|c|c|c|}
\hline \multirow{2}{*}{$\begin{array}{l}\text { Core, } \\
\text { section }\end{array}$} & \multirow{2}{*}{$\begin{array}{l}\text { Depth } \\
\text { (mbsf) }\end{array}$} & \multicolumn{5}{|c|}{ Concentration (ppmv) } & \multirow[b]{2}{*}{$C_{1} /\left(C_{2}+C_{3}\right)$} \\
\hline & & Methane & Ethene & Ethane & Propene & Propane & \\
\hline $6 \mathrm{R}-1$ & 368.00 & $7,105.94$ & 0.73 & 10.14 & - & - & 653.72 \\
\hline $8 \mathrm{R}-3$ & 390.10 & $2,647.43$ & - & 5.54 & - & 0.44 & 442.71 \\
\hline $9 R-4$ & 401.20 & $1,774.19$ & - & 3.63 & - & - & 488.76 \\
\hline 10R-2 & 407.51 & $1,191.04$ & 0.51 & 2.97 & - & - & 342.25 \\
\hline $11 \mathrm{R}-4$ & 420.40 & $3,277.63$ & - & 4.92 & 0.31 & - & 626.70 \\
\hline $12 \mathrm{R}-6$ & 433.00 & $2,490.19$ & - & 4.29 & - & - & 580.46 \\
\hline $13 R-6$ & 442.32 & $2,063.07$ & 0.48 & 3.47 & - & - & 522.30 \\
\hline $14 \mathrm{R}-4$ & 449.20 & $1,362.84$ & - & 1.58 & 0.36 & - & 702.49 \\
\hline $15 \mathrm{R}-2$ & 455.80 & $10,277.39$ & 1.24 & 17.52 & - & - & 547.84 \\
\hline 16R-1 & 463.80 & $9,980.84$ & 0.98 & 17.06 & - & - & 553.26 \\
\hline 17R-3 & 476.30 & $10,051.18$ & 1.45 & 19.88 & - & - & 471.22 \\
\hline $18 \mathrm{R}-2$ & 484.30 & $8,115.41$ & 1.11 & 12.90 & 0.44 & - & 561.62 \\
\hline $19 R-2$ & 493.80 & $10,484.87$ & 1.43 & 19.22 & - & 0.31 & 500.23 \\
\hline 20R-4 & 506.30 & $8,494.00$ & 1.82 & 28.55 & - & - & 279.68 \\
\hline $21 \mathrm{R}-2$ & 512.80 & $3,663.42$ & - & 7.86 & - & - & 466.08 \\
\hline $22 \mathrm{R}-3$ & 523.80 & $10,233.68$ & 1.20 & 22.48 & 0.46 & - & 423.93 \\
\hline $23 \mathrm{R}-3$ & 533.25 & $7,457.95$ & 1.10 & 27.37 & - & - & 261.96 \\
\hline $24 \mathrm{R}-6$ & 547.16 & $4,109.59$ & 0.91 & 9.43 & - & - & 397.45 \\
\hline $25 \mathrm{R}-6$ & 557.30 & $3,349.22$ & 0.76 & 8.70 & - & - & 354.04 \\
\hline $26 \mathrm{R}-6$ & 566.65 & $2,331.31$ & 0.67 & 9.48 & - & - & 229.69 \\
\hline $27 R-4$ & 573.11 & $1,628.86$ & 0.63 & 5.32 & - & - & 273.76 \\
\hline $28 \mathrm{R}-6$ & 586.10 & 479.91 & 0.72 & 1.11 & - & - & 262.25 \\
\hline $29 \mathrm{R}-5$ & 594.20 & $1,597.85$ & - & 4.56 & - & - & 350.41 \\
\hline $30 \mathrm{R}-7$ & 606.80 & $1,263.78$ & - & 6.79 & - & - & 186.12 \\
\hline $31 \mathrm{R}-7$ & 616.40 & $2,412.92$ & - & 6.58 & - & - & 366.71 \\
\hline $32 \mathrm{R}-4$ & 621.50 & $5,442.74$ & 1.21 & 28.93 & - & - & 180.58 \\
\hline $33 R-3$ & 629.60 & $8,090.11$ & 2.36 & 31.62 & - & - & 238.08 \\
\hline $34 \mathrm{R}-3$ & 639.30 & $6,239.52$ & 1.09 & 30.93 & - & - & 194.86 \\
\hline $35 \mathrm{R}-4$ & 650.50 & $7,939.25$ & 1.62 & 41.35 & - & - & 184.76 \\
\hline $37 R-5$ & 670.43 & $6,178.68$ & 1.54 & 24.68 & - & - & 235.65 \\
\hline $38 \mathrm{R}-3$ & 677.70 & $7,452.62$ & 1.62 & 40.73 & - & - & 175.98 \\
\hline $39 R-4$ & 688.80 & $3,711.06$ & 1.10 & 15.89 & - & - & 218.43 \\
\hline 40R-4 & 698.50 & 929.95 & - & 3.75 & 0.35 & - & 226.82 \\
\hline $41 \mathrm{R}-4$ & 708.10 & $1,857.12$ & - & 4.07 & - & - & 456.29 \\
\hline $42 \mathrm{R}-5$ & 719.03 & $5,865.74$ & - & 13.34 & - & 0.90 & 411.92 \\
\hline $43 R-5$ & 728.70 & $3,831.56$ & 0.87 & 19.47 & - & - & 188.38 \\
\hline 44R-4 & 736.84 & $2,957.70$ & - & 9.08 & - & - & 325.74 \\
\hline $45 \mathrm{R}-7$ & 750.72 & 932.06 & 0.73 & 5.74 & - & - & 144.06 \\
\hline $46 \mathrm{R}-5$ & 757.54 & $13,654.28$ & 2.90 & 89.19 & - & 17.50 & 124.59 \\
\hline 47R-2 & 762.60 & $5,097.19$ & 1.60 & 34.74 & - & 7.30 & 116.80 \\
\hline $48 \mathrm{R}-2$ & 772.29 & $4,798.57$ & 1.55 & 30.74 & 0.38 & 1.00 & 142.52 \\
\hline $49 \mathrm{R}-3$ & 782.80 & $8,784.53$ & 1.48 & 46.59 & - & 7.73 & 157.43 \\
\hline 50R-1 & 789.90 & $18,107.63$ & 2.44 & 125.11 & 0.76 & 37.11 & 109.46 \\
\hline $51 \mathrm{R}-6$ & 806.97 & $15,788.83$ & 1.65 & 90.98 & - & 0.93 & 168.76 \\
\hline $52 \mathrm{R}-9$ & 818.73 & 1,244.99 & 0.86 & 12.46 & - & 0.43 & 90.54 \\
\hline $53 \mathrm{R}-2$ & 819.72 & $2,963.83$ & - & 16.66 & - & - & 177.90 \\
\hline $54 \mathrm{R}-2$ & 830.13 & $3,797.47$ & 0.54 & 15.30 & - & - & 239.74 \\
\hline 56R-CC & 847.75 & $1,884.53$ & - & 11.55 & - & - & 163.16 \\
\hline 57R-7 & 866.13 & $1,232.43$ & 1.28 & 19.99 & 0.32 & 9.55 & 39.58 \\
\hline $58 \mathrm{R}-7$ & 875.33 & $1,130.43$ & 0.69 & 8.67 & - & 0.43 & 115.47 \\
\hline 60R-1 & 885.90 & $8,490.25$ & 1.76 & 60.44 & - & 18.98 & 104.59 \\
\hline $62 \mathrm{R}-1$ & 905.10 & $23,759.42$ & 2.92 & 244.48 & 1.51 & 91.98 & 69.70 \\
\hline $63 R-4$ & 918.15 & $6,509.83$ & 1.27 & 45.77 & - & 16.17 & 102.99 \\
\hline 64R-4 & 929.00 & $5,421.53$ & 1.66 & 52.86 & - & 22.34 & 70.54 \\
\hline $65 \mathrm{R}-5$ & 940.00 & $2,329.88$ & 1.91 & 17.31 & 0.42 & 0.57 & 115.28 \\
\hline 66R-1 & 944.41 & 940.64 & 1.12 & 11.47 & - & - & 74.71 \\
\hline $67 \mathrm{R}-3$ & 955.74 & $1,799.29$ & 1.01 & 15.99 & - & - & 105.84 \\
\hline $68 \mathrm{R}-1$ & 962.90 & $6,516.72$ & 1.33 & 39.16 & - & 14.17 & 119.22 \\
\hline 69R-1 & 972.40 & $12,912.91$ & 3.41 & 148.71 & - & 67.32 & 58.84 \\
\hline 70R-1 & 981.90 & 579.15 & - & 7.49 & - & 0.00 & 77.32 \\
\hline
\end{tabular}

$-=$ no data. 
Table T22. Results from coulometric and CHNS analysis on whole-round squeezecake samples, Holes U1389A and U1389C-U1389E. (Continued on next page.)

\begin{tabular}{|c|c|c|c|c|c|c|c|}
\hline $\begin{array}{l}\text { Core, } \\
\text { section }\end{array}$ & $\begin{array}{l}\text { Depth } \\
\text { (mbsf) }\end{array}$ & $\begin{array}{c}\text { Calcium } \\
\text { carbonate } \\
(w t \%)\end{array}$ & $\begin{array}{c}\text { Inorganic } \\
\text { carbon } \\
(w t \%)\end{array}$ & $\begin{array}{l}\text { Total } \\
\text { carbon } \\
\text { (wt\%) }\end{array}$ & $\begin{array}{l}\text { Nitrogen } \\
\text { (wt\%) }\end{array}$ & $\begin{array}{c}\text { Organic } \\
\text { carbon } \\
(w t \%)\end{array}$ & $\mathrm{C} / \mathrm{N}$ \\
\hline \multicolumn{8}{|c|}{ 339-U1389A- } \\
\hline $1 \mathrm{H}-3$ & 3.96 & 28.39 & 3.40 & 4.40 & 0.08 & 1.00 & 12.50 \\
\hline $1 \mathrm{H}-\mathrm{CC}$ & 4.25 & 30.94 & 3.71 & 4.46 & 0.12 & 0.75 & 6.25 \\
\hline $2 \mathrm{H}-6$ & 13.20 & 24.91 & 2.99 & 3.87 & 0.05 & 0.88 & 17.60 \\
\hline $3 \mathrm{H}-6$ & 22.61 & 27.69 & 3.32 & 3.94 & 0.02 & 0.62 & 31.00 \\
\hline $4 \mathrm{H}-5$ & 30.74 & 28.05 & 3.36 & 4.29 & 0.07 & 0.93 & 13.29 \\
\hline $5 \mathrm{H}-5$ & 40.29 & 31.11 & 3.73 & 4.61 & 0.06 & 0.88 & 14.67 \\
\hline $6 \mathrm{H}-5$ & 49.75 & 27.45 & 3.29 & 4.11 & 0.08 & 0.82 & 10.25 \\
\hline $6 \mathrm{H}-\mathrm{CC}$ & 52.38 & 25.99 & 3.12 & 4.11 & 0.17 & 0.99 & 5.82 \\
\hline $7 \mathrm{H}-5$ & 59.21 & 33.58 & 4.03 & 4.71 & 0.03 & 0.68 & 22.67 \\
\hline $8 \mathrm{H}-6$ & 70.24 & 27.19 & 3.26 & 3.90 & 0.05 & 0.64 & 12.80 \\
\hline $9 \mathrm{H}-4$ & 76.07 & 31.63 & 3.79 & - & - & - & - \\
\hline $9 \mathrm{H}-6$ & 79.72 & 35.14 & 4.21 & 5.11 & 0.09 & 0.90 & 10.00 \\
\hline $10 \mathrm{H}-6$ & 88.73 & 26.71 & 3.20 & 3.96 & 0.05 & 0.76 & 15.20 \\
\hline $11 \mathrm{H}-5$ & 96.72 & 30.57 & 3.67 & 4.57 & 0.08 & 0.91 & 11.38 \\
\hline $12 X-3$ & 101.33 & 21.49 & 2.58 & 3.11 & 0.06 & 0.53 & 8.83 \\
\hline $12 \mathrm{X}-\mathrm{CC}$ & 102.50 & 26.16 & 3.14 & 4.02 & 0.16 & 0.88 & 5.50 \\
\hline $13 X-5$ & 109.01 & 29.19 & 3.50 & 4.35 & 0.06 & 0.85 & 14.17 \\
\hline $14 X-6$ & 119.10 & 30.25 & 3.63 & 4.55 & 0.03 & 0.92 & 30.67 \\
\hline $15 X-6$ & 129.03 & 34.08 & 4.09 & 5.13 & 0.07 & 1.04 & 14.86 \\
\hline $16 X-5$ & 136.58 & 34.78 & 4.17 & 5.29 & 0.07 & 1.12 & 16.00 \\
\hline $17 X-5$ & 146.54 & 25.69 & 3.08 & 4.13 & 0.07 & 1.05 & 15.00 \\
\hline $18 X-4$ & 155.30 & 30.36 & 3.64 & 4.24 & 0.01 & 0.60 & 60.00 \\
\hline $18 \mathrm{X}-\mathrm{CC}$ & 158.26 & 25.99 & 3.12 & 3.76 & 0.15 & 0.64 & 4.27 \\
\hline $19 X-5$ & 165.01 & 30.00 & 3.60 & 4.55 & 0.07 & 0.95 & 13.57 \\
\hline $20 X-6$ & 176.36 & 30.93 & 3.71 & 4.33 & 0.03 & 0.62 & 20.67 \\
\hline $21 X-5$ & 184.30 & 34.73 & 4.16 & 4.64 & 0.02 & 0.48 & 24.00 \\
\hline $22 X-4$ & 192.92 & 26.24 & 3.15 & 3.88 & 0.06 & 0.73 & 12.17 \\
\hline $23 X-4$ & 203.07 & 28.48 & 3.42 & 4.26 & 0.07 & 0.85 & 12.14 \\
\hline $24 X-4$ & 212.37 & 26.51 & 3.18 & 3.98 & 0.05 & 0.80 & 16.00 \\
\hline $25 X-6$ & 224.94 & 30.24 & 3.63 & 4.65 & 0.06 & 1.02 & 17.00 \\
\hline $25 \mathrm{X}-\mathrm{CC}$ & 226.44 & 26.77 & 3.21 & 4.39 & 0.14 & 1.18 & 8.43 \\
\hline $26 X-5$ & 233.56 & 31.01 & 3.72 & 4.79 & 0.04 & 1.07 & 26.75 \\
\hline $27 X-6$ & 243.74 & 29.40 & 3.52 & 4.35 & 0.05 & 0.83 & 16.60 \\
\hline $28 X-6$ & 254.00 & 34.99 & 4.20 & 4.83 & 0.02 & 0.63 & 31.50 \\
\hline $29 X-6$ & 263.14 & 33.67 & 4.04 & 5.23 & 0.07 & 1.19 & 17.00 \\
\hline $30 X-6$ & 272.32 & 21.99 & 2.64 & 3.92 & 0.10 & 1.28 & 12.80 \\
\hline $31 X-6$ & 281.76 & 27.09 & 3.25 & 4.20 & 0.07 & 0.95 & 13.57 \\
\hline $31 X-C C$ & 283.56 & 25.63 & 3.07 & 4.26 & 0.19 & 1.19 & 6.26 \\
\hline $32 X-6$ & 291.93 & 24.71 & 2.96 & 3.83 & 0.07 & 0.87 & 12.43 \\
\hline $33 X-5$ & 300.74 & 32.23 & 3.86 & 4.97 & 0.07 & 1.11 & 15.86 \\
\hline $34 X-5$ & 309.52 & 23.37 & 2.80 & 3.73 & 0.06 & 0.93 & 15.50 \\
\hline $35 X-4$ & 317.96 & 28.57 & 3.43 & 4.37 & 0.07 & 0.94 & 13.43 \\
\hline $36 X-1$ & 323.17 & 25.48 & 3.06 & 3.57 & 0.03 & 0.52 & 17.33 \\
\hline $37 X-3$ & 335.55 & 27.09 & 3.25 & 4.13 & 0.05 & 0.88 & 17.60 \\
\hline $37 X-C C$ & 336.43 & 27.71 & 3.32 & 3.91 & 0.05 & 0.59 & 11.80 \\
\hline $38 X-3$ & 345.16 & 25.12 & 3.01 & 3.97 & 0.07 & 0.96 & 13.71 \\
\hline $39 X-C C$ & 350.75 & 30.09 & 3.61 & 4.67 & 0.05 & 1.06 & 21.20 \\
\hline \multicolumn{8}{|c|}{ 339-U1389C- } \\
\hline 7H-6 & 65.66 & 26.91 & 3.23 & 4.01 & 0.03 & 0.78 & 26.00 \\
\hline $9 \mathrm{H}-4$ & 80.74 & 30.76 & 3.69 & 4.42 & 0.05 & 0.73 & 14.60 \\
\hline $14 X-6$ & 130.22 & 34.86 & 4.18 & 5.25 & 0.09 & 1.07 & 11.89 \\
\hline \multicolumn{8}{|c|}{ 339-U1389D- } \\
\hline $1 \mathrm{H}-4$ & 4.90 & 29.54 & 3.54 & - & - & - & - \\
\hline \multicolumn{8}{|c|}{ 339-U1389E- } \\
\hline $3 R-2$ & 341.76 & 27.00 & 3.24 & 4.10 & 0.08 & 0.86 & 10.75 \\
\hline $3 R-3$ & 343.47 & 27.74 & 3.33 & 4.46 & 0.16 & 1.13 & 7.06 \\
\hline $4 \mathrm{R}-2$ & 351.59 & 22.75 & 2.73 & 3.79 & 0.11 & 1.06 & 9.64 \\
\hline $4 \mathrm{R}-\mathrm{CC}$ & 352.64 & 28.47 & 3.41 & 4.23 & 0.09 & 0.82 & 9.11 \\
\hline $5 R-3$ & 362.34 & 21.50 & 2.58 & 3.27 & 0.08 & 0.69 & 8.63 \\
\hline $6 \mathrm{R}-1$ & 369.32 & 22.61 & 2.71 & 3.47 & 0.10 & 0.76 & 7.60 \\
\hline $8 R-3$ & 391.16 & 22.86 & 2.74 & - & - & - & - \\
\hline $9 R-4$ & 402.45 & 21.45 & 2.57 & 3.22 & 0.17 & 0.65 & 3.82 \\
\hline 10R-1 & 407.24 & 24.10 & 2.89 & 3.33 & 0.14 & 0.44 & 3.14 \\
\hline 11R-1 & 416.50 & 35.04 & 4.20 & 5.02 & 0.14 & 0.82 & 5.86 \\
\hline
\end{tabular}


Table T22 (continued).

\begin{tabular}{|c|c|c|c|c|c|c|c|}
\hline $\begin{array}{c}\text { Core, } \\
\text { section }\end{array}$ & $\begin{array}{l}\text { Depth } \\
\text { (mbsf) }\end{array}$ & $\begin{array}{c}\text { Calcium } \\
\text { carbonate } \\
(w t \%)\end{array}$ & $\begin{array}{c}\text { Inorganic } \\
\text { carbon } \\
(w t \%)\end{array}$ & $\begin{array}{c}\text { Total } \\
\text { carbon } \\
\text { (wt\%) }\end{array}$ & $\begin{array}{c}\text { Nitrogen } \\
\text { (wt\%) }\end{array}$ & $\begin{array}{c}\text { Organic } \\
\text { carbon } \\
\text { (wt\%) }\end{array}$ & $\mathrm{C} / \mathrm{N}$ \\
\hline 11R-1 & 416.50 & 34.51 & 4.14 & - & - & - & - \\
\hline $12 \mathrm{R}-3$ & 429.77 & 25.43 & 3.05 & 4.05 & 0.14 & 1.00 & 7.14 \\
\hline 13R-1 & 435.70 & - & - & 3.71 & 0.19 & - & 0.00 \\
\hline $14 \mathrm{R}-3$ & 448.47 & 24.15 & 2.90 & 3.78 & 0.15 & 0.88 & 5.87 \\
\hline $15 R-3$ & 458.14 & 22.61 & 2.71 & 3.42 & 0.18 & 0.71 & 3.94 \\
\hline 16R-1 & 464.61 & 25.11 & 3.01 & 3.85 & 0.18 & 0.84 & 4.67 \\
\hline 17R-3 & 477.08 & 26.40 & 3.17 & 4.10 & 0.25 & 0.94 & 3.76 \\
\hline $18 \mathrm{R}-1$ & 483.40 & 22.90 & 2.75 & 3.47 & 0.10 & 0.72 & 7.20 \\
\hline 19R-1 & 492.89 & 23.93 & 2.87 & 3.93 & 0.22 & 1.06 & 4.82 \\
\hline $20 R-5$ & 509.12 & 25.37 & 3.04 & 3.96 & 0.24 & 0.92 & 3.83 \\
\hline $21 R-3$ & 515.29 & 28.26 & 3.39 & 4.31 & 0.14 & 0.92 & 6.57 \\
\hline $22 \mathrm{R}-3$ & 525.16 & 25.03 & 3.00 & 3.87 & 0.09 & 0.87 & 9.67 \\
\hline $23 R-3$ & 534.62 & 25.46 & 3.05 & 4.01 & 0.13 & 0.96 & 7.38 \\
\hline $24 \mathrm{R}-5$ & 547.00 & 25.98 & 3.12 & 4.19 & 0.17 & 1.08 & 6.35 \\
\hline $25 R-6$ & 557.79 & 27.44 & 3.29 & 4.38 & 0.24 & 1.09 & 4.54 \\
\hline $26 R-4$ & 565.18 & 24.72 & 2.96 & 4.03 & 0.23 & 1.07 & 4.65 \\
\hline 28R-1 & 579.20 & 21.21 & 2.54 & 3.22 & 0.17 & 0.68 & 4.00 \\
\hline 29R-3 & 592.12 & 27.03 & 3.24 & 3.99 & 0.11 & 0.75 & 6.82 \\
\hline $30 \mathrm{R}-4$ & 603.61 & - & - & 4.82 & 0.12 & - & 0.00 \\
\hline 31R-3 & 611.83 & 28.03 & 3.36 & 4.36 & 0.08 & 1.00 & 12.50 \\
\hline $32 \mathrm{R}-1$ & 617.78 & 30.42 & 3.65 & 4.50 & 0.09 & 0.85 & 9.44 \\
\hline $33 R-3$ & 630.19 & 27.29 & 3.27 & 4.34 & 0.11 & 1.07 & 9.73 \\
\hline $34 R-5$ & 643.62 & 30.13 & 3.61 & 4.26 & 0.07 & 0.65 & 9.29 \\
\hline $34 R-6$ & 644.18 & 29.81 & 3.57 & 4.64 & 0.09 & 1.07 & 11.89 \\
\hline $35 \mathrm{R}-5$ & 653.01 & 28.51 & 3.42 & 4.31 & 0.10 & 0.89 & 8.90 \\
\hline $37 R-6$ & 673.30 & 31.30 & 3.75 & 4.48 & 0.08 & 0.73 & 9.13 \\
\hline $38 R-4$ & 680.60 & 29.87 & 3.58 & 4.39 & 0.07 & 0.81 & 11.57 \\
\hline $39 R-6$ & 692.80 & 33.70 & 4.04 & 4.33 & 0.09 & 0.29 & 3.22 \\
\hline $40 R-4$ & 698.94 & 32.53 & 3.90 & 4.41 & 0.04 & 0.51 & 12.75 \\
\hline $41 \mathrm{R}-3$ & 707.57 & 26.80 & 3.21 & 4.02 & 0.06 & 0.81 & 13.50 \\
\hline $41 \mathrm{R}-3$ & 707.90 & 28.00 & 3.36 & 3.91 & 0.08 & 0.55 & 6.88 \\
\hline $43 R-3$ & 726.23 & 29.44 & 3.53 & 4.67 & 0.10 & 1.14 & 11.40 \\
\hline 44R-2 & 734.60 & 31.20 & 3.74 & 4.74 & 0.11 & 1.00 & 9.09 \\
\hline 46R-3 & 755.35 & 27.39 & 3.28 & 4.64 & 0.12 & 1.36 & 11.33 \\
\hline 47R-1 & 761.71 & 32.66 & 3.92 & 4.91 & 0.09 & 0.99 & 11.00 \\
\hline 48R-2 & 772.19 & 31.59 & 3.79 & 5.07 & 0.13 & 1.28 & 9.85 \\
\hline 49R-3 & 783.50 & 30.51 & 3.66 & 5.32 & 0.14 & 1.66 & 11.86 \\
\hline 50R-1 & 790.73 & 30.03 & 3.60 & 4.53 & 0.14 & 0.93 & 6.64 \\
\hline $51 R-5$ & 806.64 & 24.30 & 2.91 & 4.20 & 0.11 & 1.29 & 11.73 \\
\hline $52 \mathrm{R}-6$ & 816.03 & 31.02 & 3.72 & 4.94 & 0.12 & 1.22 & 10.17 \\
\hline $53 R-2$ & 820.06 & 31.61 & 3.79 & 4.75 & 0.06 & 0.96 & 16.00 \\
\hline $56 \mathrm{R}-\mathrm{CC}$ & 847.75 & 32.62 & 3.91 & 5.06 & 0.07 & 1.15 & 16.43 \\
\hline 57R-6 & 865.80 & 26.45 & 3.17 & 4.97 & 0.14 & 1.80 & 12.86 \\
\hline 58R-6 & 874.86 & 31.91 & 3.83 & 4.73 & 0.05 & 0.90 & 18.00 \\
\hline $63 R-4$ & 919.50 & 31.40 & 3.76 & 4.74 & 0.07 & 0.98 & 14.00 \\
\hline $64 R-5$ & 931.48 & 33.83 & 4.06 & 5.03 & 0.07 & 0.97 & 13.86 \\
\hline $65 R-6$ & 942.83 & 31.95 & 3.83 & 4.90 & 0.08 & 1.07 & 13.38 \\
\hline $67 R-3$ & 955.63 & 33.30 & 3.99 & 5.02 & 0.07 & 1.03 & 14.71 \\
\hline 70R-1 & 982.52 & 31.14 & 3.73 & 4.59 & 0.07 & 0.86 & 12.29 \\
\hline
\end{tabular}

$-=$ no data. 
Table T23. Interstitial water major and trace elements, Site U1389. (Continued on next page.)

\begin{tabular}{|c|c|c|c|c|c|c|c|c|c|}
\hline $\begin{array}{l}\text { Core, section, } \\
\text { interval }(\mathrm{cm})\end{array}$ & $\begin{array}{l}\text { Depth } \\
\text { (mbsf) }\end{array}$ & $\begin{array}{c}\text { B }(\mu \mathrm{M}) \\
208.96 \mathrm{~nm} \\
\text { ICPAES }\end{array}$ & $\begin{array}{c}\mathrm{Ba}(\mu \mathrm{M}) \\
493.41 \mathrm{~nm} \\
\text { ICPAES }\end{array}$ & $\begin{array}{c}\mathrm{Fe}(\mu \mathrm{M}) \\
259.94 \mathrm{~nm} \\
\text { ICPAES }\end{array}$ & $\begin{array}{c}\mathrm{Li}(\mu \mathrm{M}) \\
670.78 \mathrm{~nm} \\
\text { ICPAES }\end{array}$ & $\begin{array}{c}\mathrm{Si}(\mu \mathrm{M}) \\
251.61 \mathrm{~nm} \\
\text { ICPAES }\end{array}$ & $\begin{array}{c}\mathrm{Sr}(\mu \mathrm{M}) \\
407.77 \mathrm{~nm} \\
\text { ICPAES }\end{array}$ & $\begin{array}{c}\mathrm{Cl}^{-}(\mathrm{mM}) \\
\text { TITRA_AUTO }\end{array}$ & $\begin{array}{c}\mathrm{Na}^{+}(\mathrm{mM}) \\
\text { IC }\end{array}$ \\
\hline \multicolumn{10}{|l|}{ 339-U1389A- } \\
\hline $1 \mathrm{H}-2,145-150$ & 2.95 & 479.69 & -15.73 & 77.49 & 43.43 & 318.18 & 72.61 & 584.78 & 490.80 \\
\hline $2 \mathrm{H}-6,145-150$ & 13.27 & 510.69 & 19.07 & 29.62 & 24.82 & 188.40 & 62.87 & 578.29 & 450.74 \\
\hline $3 \mathrm{H}-6,145-150$ & 22.69 & 502.77 & 7.33 & 31.98 & 22.11 & 188.00 & 66.93 & 578.34 & 485.28 \\
\hline $4 \mathrm{H}-6,145-150$ & 32.30 & 438.62 & 3.55 & 20.09 & 27.37 & 135.86 & 71.29 & 575.97 & 490.17 \\
\hline $5 \mathrm{H}-6,145-150$ & 41.86 & 414.97 & -5.00 & 22.81 & 22.65 & 170.29 & 72.75 & 576.89 & 503.88 \\
\hline $6 \mathrm{H}-6,145-150$ & 51.33 & 419.83 & 0.87 & 9.04 & 24.01 & 165.31 & 74.91 & 574.20 & 501.57 \\
\hline 7H-6, 117-122 & 60.57 & 396.36 & 15.36 & 5.62 & 27.35 & 114.49 & 77.94 & 572.41 & 490.69 \\
\hline $8 \mathrm{H}-6,146-151$ & 70.34 & 395.73 & 16.08 & 9.93 & 25.42 & 136.62 & 76.61 & 571.83 & 503.48 \\
\hline $9 \mathrm{H}-6,148-153$ & 79.90 & 410.86 & 8.72 & 4.72 & 26.46 & 166.06 & 77.47 & 576.15 & 504.01 \\
\hline $10 \mathrm{H}-6,136-141$ & 89.27 & 359.90 & 5.73 & 16.19 & 30.16 & 201.57 & 79.37 & 575.47 & 495.75 \\
\hline $11 \mathrm{H}-4,141-146$ & 95.45 & 418.63 & 7.90 & 1.59 & 35.58 & 269.91 & 85.29 & 573.04 & 499.15 \\
\hline $12 X-2,140-150$ & 100.11 & 372.85 & 9.65 & 4.96 & 29.11 & 327.08 & 80.28 & 573.09 & 509.99 \\
\hline $13 X-4,140-150$ & 107.60 & 355.26 & 11.49 & 1.77 & 29.67 & 216.36 & 78.41 & 576.81 & 509.50 \\
\hline $14 X-5,140-150$ & 117.57 & 348.54 & 18.00 & 2.68 & 33.06 & 185.35 & 84.58 & 575.25 & 497.28 \\
\hline $15 X-4,140-150$ & 126.70 & 363.28 & 11.18 & 6.93 & 28.34 & 210.87 & 81.32 & 570.76 & 520.62 \\
\hline $16 X-5,140-150$ & 136.71 & 327.28 & 12.28 & 3.17 & 31.08 & 212.87 & 83.92 & 577.38 & 501.93 \\
\hline $17 X-4,140-150$ & 145.07 & 324.47 & 14.87 & 2.11 & 33.17 & 274.10 & 83.25 & 575.70 & 521.42 \\
\hline $18 X-4,140-150$ & 155.40 & 293.19 & 13.27 & 1.96 & 41.08 & 116.77 & 89.31 & 577.25 & 513.79 \\
\hline $19 X-5,140-150$ & 165.12 & 325.52 & 7.16 & 2.10 & 27.76 & 178.19 & 87.00 & 580.56 & 512.59 \\
\hline $20 X-4,140-150$ & 173.80 & 288.29 & 9.85 & 1.76 & 29.57 & 187.02 & 87.99 & 580.45 & 525.26 \\
\hline $21 X-5,140-150$ & 184.41 & 325.07 & 16.62 & 2.13 & 37.15 & 246.32 & 90.18 & 581.48 & 506.27 \\
\hline $22 X-4,140-150$ & 193.04 & 249.09 & 21.24 & 2.94 & 41.84 & 393.60 & 94.42 & 583.12 & 504.75 \\
\hline $23 X-4,140-150$ & 203.20 & 279.11 & 19.63 & 2.04 & 35.70 & 170.43 & 90.00 & 586.65 & 506.44 \\
\hline $26 X-3,140-150$ & 230.60 & 302.79 & 9.57 & 1.57 & 49.20 & 396.78 & 92.43 & 598.44 & 522.62 \\
\hline $29 X-6,100-110$ & 263.40 & 288.51 & 23.85 & 9.04 & 60.93 & 279.54 & 103.22 & 613.29 & 530.72 \\
\hline $32 X-6,91-101$ & 292.21 & 222.46 & 38.40 & 2.15 & 64.67 & 223.59 & 119.66 & 660.41 & 582.83 \\
\hline $35 X-4,140-150$ & 318.10 & 218.30 & 43.81 & 2.31 & 56.71 & 183.45 & 172.42 & 731.66 & 628.44 \\
\hline $38 X-2,140-150$ & 343.90 & 231.96 & 47.22 & 1.60 & 81.28 & 182.20 & 224.71 & 774.68 & 659.20 \\
\hline \multicolumn{10}{|l|}{ 339-U1389E- } \\
\hline $4 \mathrm{R}-2,140-150$ & 351.70 & 229.74 & 51.49 & 1.07 & 54.11 & 220.93 & 245.17 & 786.10 & 589.73 \\
\hline $8 R-1,140-150$ & 388.50 & 263.47 & 45.94 & 2.96 & 55.44 & 108.95 & 321.86 & 831.76 & 666.97 \\
\hline $11 \mathrm{R}-3,140-150$ & 420.30 & 264.74 & 60.84 & 2.70 & 57.04 & 215.61 & 348.29 & 866.47 & 627.81 \\
\hline $14 \mathrm{R}-3,140-150$ & 449.10 & 260.14 & 69.48 & 0.84 & 66.91 & 118.37 & 380.18 & 880.09 & 642.41 \\
\hline $17 \mathrm{R}-2,140-150$ & 476.20 & 254.68 & 81.02 & 2.53 & 75.18 & 107.98 & 444.25 & 899.23 & 686.77 \\
\hline $20 \mathrm{R}-3,140-150$ & 506.20 & 240.66 & 96.85 & 1.49 & 73.16 & 122.69 & 452.76 & 907.61 & 691.88 \\
\hline $23 R-2,140-150$ & 533.15 & 249.78 & 136.42 & 3.57 & 89.94 & 128.28 & 539.29 & 942.15 & 664.01 \\
\hline $26 \mathrm{R}-4,140-150$ & 565.30 & 228.50 & 54.91 & 3.29 & 74.91 & 143.27 & 339.13 & 788.91 & 587.01 \\
\hline 30R-1, 140-150 & 599.20 & 224.54 & 39.91 & 3.80 & 62.84 & 153.25 & 212.71 & 621.90 & 542.43 \\
\hline $32 \mathrm{R}-3,140-150$ & 621.40 & 215.75 & 29.07 & 0.89 & 53.32 & 108.64 & 134.27 & 533.60 & 457.81 \\
\hline $35 R-3,140-150$ & 650.40 & 251.05 & 18.88 & 1.37 & 58.32 & 151.53 & 109.77 & 449.76 & 410.76 \\
\hline $38 \mathrm{R}-2,135-150$ & 677.55 & 201.05 & 12.15 & 2.92 & 67.65 & 110.07 & 101.93 & 418.72 & 390.57 \\
\hline $41 \mathrm{R}-2,140-150$ & 706.50 & 235.87 & 7.08 & 2.61 & 70.54 & 179.00 & 84.27 & 371.35 & 334.51 \\
\hline $44 R-3,135-150$ & 736.69 & 261.71 & 8.71 & 1.28 & 68.05 & 111.89 & 87.61 & 390.57 & 365.54 \\
\hline $45 R-4,135-150$ & 747.76 & 267.47 & 2.74 & 1.37 & 70.10 & 131.28 & 89.36 & 386.43 & 364.73 \\
\hline 46R-4, 135-150 & 757.39 & 238.45 & 8.55 & 3.93 & 84.89 & 170.08 & 93.73 & 356.46 & 323.79 \\
\hline $47 \mathrm{R}-1,135-150$ & 762.45 & 265.08 & 12.34 & 0.82 & 74.19 & 166.25 & 82.00 & 365.51 & 329.30 \\
\hline $49 \mathrm{R}-2,86-100$ & 782.66 & 230.94 & 10.17 & 1.13 & 72.84 & 128.98 & 83.53 & 367.54 & 326.44 \\
\hline $51 \mathrm{R}-5,135-150$ & 806.82 & 188.93 & 9.85 & 0.54 & 66.07 & 144.24 & 85.31 & 355.70 & 326.72 \\
\hline $52 \mathrm{R}-4,135-150$ & 813.72 & 189.42 & 7.36 & 1.84 & 67.13 & 108.78 & 82.78 & 349.31 & 320.83 \\
\hline 57R-5, 135-150 & 864.48 & 241.22 & 5.20 & 0.64 & 59.96 & 139.27 & 86.03 & 354.60 & 334.49 \\
\hline 58R-4, 135-150 & 872.57 & 264.78 & 5.23 & 1.46 & 61.64 & 147.52 & 86.74 & 347.56 & 315.14 \\
\hline $63 \mathrm{R}-3,135-150$ & 918.00 & 164.28 & 3.99 & 2.54 & 64.30 & 90.70 & 101.54 & 353.19 & 328.07 \\
\hline $64 \mathrm{R}-3,135-150$ & 928.85 & 195.29 & 5.37 & 1.47 & 63.89 & 104.27 & 101.07 & 358.42 & 325.48 \\
\hline $65 R-4,135-150$ & 939.85 & 241.26 & 1.93 & 1.58 & 67.71 & 148.30 & 99.23 & 349.25 & 325.34 \\
\hline
\end{tabular}

TITRA_AUTO = automatic titration, SPEC = spectrometer, IC = ion chromatograph, ICPAES = inductively coupled plasma-atomic emission spectrometer, ISE = ion-selective electrode. 
Table T23 (continued).

\begin{tabular}{|c|c|c|c|c|c|c|c|c|c|c|}
\hline $\begin{array}{l}\text { Core, section, } \\
\text { interval }(\mathrm{cm})\end{array}$ & $\begin{array}{l}\text { Depth } \\
\text { (mbsf) }\end{array}$ & $\mathrm{Na}^{+} / \mathrm{Cl}^{-}$ & $\begin{array}{c}\mathrm{SO}_{4}{ }^{2-}(\mathrm{mM}) \\
\mathrm{IC}\end{array}$ & $\begin{array}{l}\mathrm{K}^{+}(\mathrm{mM}) \\
\mathrm{IC}\end{array}$ & $\begin{array}{c}\mathrm{Mg}^{2+}(\mathrm{mM}) \\
\mathrm{IC}^{-}\end{array}$ & $\begin{array}{c}\mathrm{Ca}^{2+}(\mathrm{mM}) \\
\text { IC }\end{array}$ & $\begin{array}{c}\text { Alkalinity } \\
\text { (meq/L) } \\
\text { TITRA_AUTO }\end{array}$ & $\begin{array}{l}\text { Salinity } \\
(\%)\end{array}$ & $\begin{array}{c}\mathrm{NH}_{4}^{+}(\mu \mathrm{M}) \\
\text { SPEC }\end{array}$ & $\begin{array}{l}\mathrm{pH} \\
\mathrm{ISE}\end{array}$ \\
\hline \multicolumn{11}{|l|}{ 339-U1389A- } \\
\hline $1 \mathrm{H}-2,145-150$ & 2.95 & 0.84 & 18.43 & 9.96 & 51.33 & 7.70 & 10.25 & 4.0 & 1005.7 & 7.68 \\
\hline $2 \mathrm{H}-6,145-150$ & 13.27 & 0.78 & 0 & 7.96 & 34.85 & 3.41 & 7.84 & 3.7 & 2751.7 & 7.79 \\
\hline $3 \mathrm{H}-6,145-150$ & 22.69 & 0.84 & 0 & 8.47 & 35.00 & 5.05 & 6.32 & 3.6 & 3304.8 & 7.86 \\
\hline $4 \mathrm{H}-6,145-150$ & 32.30 & 0.85 & 0 & 8.52 & 34.27 & 5.70 & 5.67 & 3.7 & 3479.3 & 7.88 \\
\hline $5 \mathrm{H}-6,145-150$ & 41.86 & 0.87 & 0 & 8.30 & 34.41 & 6.15 & 5.23 & 3.6 & 3287.2 & 7.80 \\
\hline $6 \mathrm{H}-6,145-150$ & 51.33 & 0.87 & 0 & 8.11 & 34.33 & 6.01 & 4.09 & 3.5 & 3176.3 & 7.89 \\
\hline $7 \mathrm{H}-6,117-122$ & 60.57 & 0.86 & 0 & 8.01 & 32.67 & 6.02 & 5.02 & 3.6 & 3120.1 & 8.02 \\
\hline $8 \mathrm{H}-6,146-151$ & 70.34 & 0.88 & 0 & 7.85 & 33.27 & 6.17 & 4.44 & 3.5 & 3167.8 & 7.95 \\
\hline $9 \mathrm{H}-6,148-153$ & 79.90 & 0.87 & 0 & 7.77 & 32.72 & 6.32 & 5.41 & 3.6 & 3406.2 & 7.94 \\
\hline $10 \mathrm{H}-6,136-141$ & 89.27 & 0.86 & 0 & 7.43 & 33.17 & 6.60 & 6.96 & 3.5 & 3576.3 & 8.08 \\
\hline $11 \mathrm{H}-4,141-146$ & 95.45 & 0.87 & 0 & 7.32 & 32.80 & 6.10 & 6.78 & 3.5 & 3927.9 & 7.96 \\
\hline $12 X-2,140-150$ & 100.11 & 0.89 & 0 & 7.25 & 33.77 & 6.09 & 6.46 & 3.4 & 3875.9 & 7.98 \\
\hline $13 X-4,140-150$ & 107.60 & 0.88 & 0 & 7.30 & 32.71 & 6.22 & 6.56 & 3.4 & 3986.5 & 7.98 \\
\hline $14 X-5,140-150$ & 117.57 & 0.86 & 0 & 6.91 & 31.62 & 6.02 & 5.03 & 3.4 & 3962.4 & 7.99 \\
\hline $15 X-4,140-150$ & 126.70 & 0.91 & 0 & 7.05 & 32.92 & 6.29 & 5.44 & 3.4 & 3948.4 & 7.95 \\
\hline $16 X-5,140-150$ & 136.71 & 0.87 & 0 & 6.77 & 31.98 & 6.41 & 5.55 & 3.4 & 4045.6 & 8.02 \\
\hline $17 X-4,140-150$ & 145.07 & 0.91 & 0 & 7.07 & 32.49 & 6.34 & 5.39 & 3.4 & 4191.7 & 7.98 \\
\hline $18 X-4,140-150$ & 155.40 & 0.89 & 0 & 7.12 & 31.72 & 6.48 & 5.33 & 3.4 & 4255.8 & 8.22 \\
\hline $19 X-5,140-150$ & 165.12 & 0.88 & 0 & 6.57 & 32.47 & 6.58 & 4.92 & 3.4 & 3923.2 & 7.96 \\
\hline $20 X-4,140-150$ & 173.80 & 0.90 & 0 & 6.58 & 33.17 & 6.66 & 5.11 & 3.4 & 4001.2 & 8.03 \\
\hline $21 X-5,140-150$ & 184.41 & 0.87 & 0 & 6.48 & 32.05 & 7.10 & 5.11 & 3.4 & 4276.6 & 8.91 \\
\hline $22 X-4,140-150$ & 193.04 & 0.87 & 0 & 5.77 & 32.38 & 7.39 & NA & 3.4 & 4006.4 & NA \\
\hline $23 X-4,140-150$ & 203.20 & 0.86 & 0 & 5.95 & 32.00 & 6.90 & 4.39 & 3.4 & 4322.2 & 8.39 \\
\hline $26 \mathrm{X}-3,140-150$ & 230.60 & 0.87 & 0 & 6.47 & 33.53 & 7.68 & NA & 3.5 & 4650.6 & NA \\
\hline $29 X-6,100-110$ & 263.40 & 0.87 & 0 & 6.40 & 35.52 & 7.24 & 7.68 & 3.7 & 4682.3 & 7.96 \\
\hline $32 X-6,91-101$ & 292.21 & 0.88 & 0 & 6.49 & 40.23 & 9.31 & 7.10 & 3.9 & 3864.0 & 8.05 \\
\hline $35 X-4,140-150$ & 318.10 & 0.86 & 0 & 6.82 & 46.78 & 10.96 & 3.13 & 4.3 & 4267.8 & 7.93 \\
\hline $38 X-2,140-150$ & 343.90 & 0.85 & 0 & 6.95 & 51.16 & 12.97 & 3.00 & 4.6 & 4445.8 & 8.73 \\
\hline \multicolumn{11}{|l|}{ 339-U1389E- } \\
\hline $4 \mathrm{R}-2,140-150$ & 351.70 & 0.75 & 0 & 5.83 & 48.29 & 13.41 & 2.54 & 4.9 & 5057.3 & 7.99 \\
\hline $8 R-1,140-150$ & 388.50 & 0.80 & 0 & 6.61 & 58.28 & 15.83 & 2.43 & 5.1 & 5213.2 & 7.92 \\
\hline $11 \mathrm{R}-3,140-150$ & 420.30 & 0.72 & 0 & 6.05 & 55.34 & 16.00 & 2.19 & 5.2 & 5563.1 & 7.96 \\
\hline $14 \mathrm{R}-3,140-150$ & 449.10 & 0.73 & 0 & 6.68 & 55.56 & 16.79 & 1.80 & 5.3 & 5865.9 & 7.91 \\
\hline $17 \mathrm{R}-2,140-150$ & 476.20 & 0.76 & 0 & 7.07 & 59.88 & 18.72 & 2.12 & 5.3 & 5801.0 & 8.05 \\
\hline $20 \mathrm{R}-3,140-150$ & 506.20 & 0.76 & 0 & 6.71 & 62.96 & 19.08 & 2.45 & 5.4 & 6169.0 & 7.84 \\
\hline $23 \mathrm{R}-2,140-150$ & 533.15 & 0.70 & 0 & 6.12 & 63.60 & 20.05 & 2.17 & 5.6 & 6484.6 & 7.73 \\
\hline $26 \mathrm{R}-4,140-150$ & 565.30 & 0.74 & 0 & 5.68 & 48.21 & 13.98 & 3.09 & 4.8 & 5861.8 & 7.79 \\
\hline $30 \mathrm{R}-1,140-150$ & 599.20 & 0.87 & 0 & 4.74 & 31.17 & 8.87 & 3.84 & 3.7 & 5427.1 & 8.01 \\
\hline $32 \mathrm{R}-3,140-150$ & 621.40 & 0.86 & 0 & 4.51 & 20.12 & 6.07 & 3.59 & 3.2 & 5379.2 & 8.21 \\
\hline $35 R-3,140-150$ & 650.40 & 0.91 & 0 & 3.72 & 14.17 & 5.17 & 4.42 & 2.7 & 4857.7 & 8.16 \\
\hline $38 \mathrm{R}-2,135-150$ & 677.55 & 0.93 & 0 & 4.00 & 13.73 & 3.84 & 4.00 & 2.7 & 4842.1 & 8.24 \\
\hline $41 \mathrm{R}-2,140-150$ & 706.50 & 0.90 & 0 & 3.12 & 11.14 & 2.68 & 7.03 & 2.4 & 4579.3 & 8.35 \\
\hline $44 \mathrm{R}-3,135-150$ & 736.69 & 0.94 & 3.17 & 3.87 & 13.97 & 3.53 & 8.36 & 2.5 & 4841.4 & 8.26 \\
\hline $45 R-4,135-150$ & 747.76 & 0.94 & 3.71 & 3.83 & 14.63 & 3.85 & 8.34 & 2.5 & 4728.3 & 8.23 \\
\hline $46 \mathrm{R}-4,135-150$ & 757.39 & 0.91 & 0 & 3.00 & 10.45 & 2.88 & 7.38 & 2.2 & 4384.2 & 8.07 \\
\hline 47R-1, 135-150 & 762.45 & 0.90 & 0 & 3.03 & 10.49 & 2.91 & 7.01 & 2.2 & 4394.3 & 8.21 \\
\hline $49 \mathrm{R}-2,86-100$ & 782.66 & 0.89 & 0 & 3.10 & 10.07 & 2.98 & 5.85 & 2.3 & 4392.9 & 7.96 \\
\hline 51R-5, 135-150 & 806.82 & 0.92 & 0 & 2.77 & 10.04 & 3.36 & 4.19 & 2.2 & 4292.3 & 8.23 \\
\hline $52 \mathrm{R}-4,135-150$ & 813.72 & 0.92 & 0 & 2.90 & 8.99 & 2.77 & 4.70 & 2.1 & 4329.4 & 8.41 \\
\hline $57 \mathrm{R}-5,135-150$ & 864.48 & 0.94 & 0 & 3.08 & 10.09 & 2.91 & 6.06 & 2.2 & 4303.1 & 8.33 \\
\hline $58 \mathrm{R}-4,135-150$ & 872.57 & 0.91 & 0 & 2.71 & 8.92 & 2.81 & 6.71 & 2.1 & 4394.8 & 8.24 \\
\hline $63 \mathrm{R}-3,135-150$ & 918.00 & 0.93 & 0 & 2.81 & 8.65 & 2.96 & 3.55 & 2.1 & 4350.6 & 8.37 \\
\hline $64 \mathrm{R}-3,135-150$ & 928.85 & 0.91 & 0 & 2.67 & 8.92 & 3.28 & 4.06 & 2.1 & 4304.7 & 8.25 \\
\hline $65 \mathrm{R}-4,135-150$ & 939.85 & 0.93 & 0 & 2.63 & 8.60 & 3.39 & 5.69 & 2.1 & 4321.2 & 8.18 \\
\hline
\end{tabular}


Table T24. Interstitial oxygen and hydrogen isotopes, Site U1389.

\begin{tabular}{lrcc}
\hline $\begin{array}{c}\text { Core, section, } \\
\text { interval (cm) }\end{array}$ & $\begin{array}{r}\text { Depth } \\
(\mathrm{mbsf})\end{array}$ & $\begin{array}{c}\delta^{18} \mathrm{O} \\
(\% \mathrm{~N}, \mathrm{VSMOW})\end{array}$ & $\begin{array}{c}\delta \mathrm{D} \\
(\% \circ, \mathrm{VSMOW})\end{array}$ \\
\hline 339-U1389A- & & & \\
1H-1, 145-150 & 1.50 & 0.77 & 5.94 \\
3H-6, 145-150 & 22.75 & 0.81 & 8.64 \\
6H-6, 145-150 & 51.42 & 1.13 & 9.06 \\
13X-4, 140-145 & 107.70 & 1.22 & 8.00 \\
14X-5, 140-145 & 117.67 & 0.97 & 8.30 \\
15X-4, 140-145 & 126.80 & 0.88 & 7.27 \\
16X-5, 140-145 & 136.81 & 0.93 & 7.11 \\
17X-4, 140-145 & 145.17 & 0.95 & 7.58 \\
18X-4, 140-145 & 155.50 & 0.75 & 6.87 \\
19X-5, 140-145 & 165.22 & 0.92 & 7.54 \\
20X-4, 140-145 & 173.90 & 1.17 & 7.10 \\
21X-5, 140-145 & 184.51 & 1.03 & 7.80 \\
22X-4, 140-145 & 193.14 & 1.07 & 7.38 \\
23X-4, 140-145 & 203.30 & 0.89 & 7.93 \\
26X-3, 140-145 & 230.70 & 1.05 & 5.29 \\
29X-6, 100-105 & 263.50 & 1.23 & 5.35 \\
32X-6, 91-96 & 292.31 & 1.22 & 1.37 \\
35X-4, 140-145 & 318.20 & 1.15 & -0.47 \\
38X-2, 140-145 & 344.00 & 1.49 & -1.29 \\
339-U1389E- & & & \\
4R-2, 140-145 & 351.80 & 1.57 & -1.83 \\
8R-1, 140-145 & 388.60 & 1.40 & -2.93 \\
11R-3, 140-145 & 420.40 & 2.05 & -3.75 \\
23R-2, 140-145 & 533.25 & 1.91 & -10.80 \\
26R-4, 140-145 & 565.40 & 0.83 & -3.14 \\
30R-1, 140-145 & 599.30 & 1.99 & -7.14 \\
32R-3, 140-145 & 621.50 & 1.95 & -7.22 \\
35R-3, 140-145 & 650.50 & 0.81 & -7.58 \\
38R-2, 135-140 & 677.70 & 1.71 & -8.88 \\
41R-2, 140-145 & 697.00 & 1.98 & -9.08 \\
44R-3, 135-140 & 736.84 & 1.80 & -8.77 \\
45R-4, 135-140 & 747.91 & 1.76 & -7.95 \\
\hline
\end{tabular}

VSMOW = Vienna standard mean ocean water.

Table T25. Vertical seismic profile station and traveltime information, Site U1389.

\begin{tabular}{cccccc}
\hline $\begin{array}{c}\text { Depth WSF } \\
(\mathrm{m})\end{array}$ & $\begin{array}{c}\text { Water depth* } \\
(\mathrm{mbsl})\end{array}$ & $\begin{array}{c}\text { One-way } \\
\text { traveltime } \\
(\mathrm{ms})\end{array}$ & $\begin{array}{c}\text { One-way } \\
\text { traveltime, } \\
\text { corrected } \\
(\mathrm{ms})\end{array}$ & $\begin{array}{c}\text { Two-way } \\
\text { traveltime } \\
(\mathrm{ms})\end{array}$ & $\begin{array}{c}\text { Two-way } \\
\text { traveltime below } \\
\text { seabed* } \\
\left(\mathrm{ms}^{*}\right.\end{array}$ \\
\hline 110.0 & 755.0 & 486.0 & 495.0 & 990.0 & 135.0 \\
133.0 & 778.0 & 499.0 & 508.0 & 1016.0 & 161.0 \\
163.1 & 808.1 & 516.0 & 525.0 & 1050.0 & 195.0 \\
197.0 & 842.0 & 534.0 & 543.0 & 1086.0 & 231.0 \\
212.0 & 857.0 & 542.5 & 551.5 & 1103.0 & 248.0 \\
251.1 & 896.1 & 564.0 & 573.0 & 1146.0 & 291.0 \\
276.1 & 921.1 & 577.0 & 586.0 & 1172.0 & 317.0 \\
292.7 & 937.7 & 586.5 & 595.5 & 1191.0 & 336.0 \\
320.0 & 965.0 & 600.5 & 609.5 & 1219.0 & 364.0 \\
355.3 & 1000.3 & 618.0 & 627.0 & 1254.0 & 399.0 \\
\hline
\end{tabular}

* = seafloor at $656 \mathrm{mbsl}$, two-way traveltime of $855 \mathrm{~ms}$ by precision depth recorder. $\dagger=$ between the near field hydrophone and Versatile Seismic Imager geophone. $\ddagger=$ a correction of $9 \mathrm{~ms}$ is added to the one-way traveltime to adjust to sea level datum. 
Table T26. Results from APCT-3 temperature profiles, Site U1386.

\begin{tabular}{lccccc}
\hline Core & $\begin{array}{c}\text { Original } \\
\text { depth } \\
(\mathrm{mbsf})\end{array}$ & $\begin{array}{c}\text { Tidal sea } \\
\text { level height* } \\
(\mathrm{m})\end{array}$ & $\begin{array}{c}\text { Corrected } \\
\text { depth } \\
(\mathrm{mbsf})\end{array}$ & $\begin{array}{c}\text { In situ } \\
\text { temperature } \\
\left({ }^{\circ} \mathrm{C}\right)\end{array}$ & $\begin{array}{c}\text { Thermal } \\
\text { resistance } \\
\left(\mathrm{m}^{2} \mathrm{~K} / \mathrm{W}\right)\end{array}$ \\
\hline $\begin{array}{l}\text { 339-U1389A- } \\
\text { 4H }\end{array}$ & 32.8 & -1 & 33.9 & 14 & 27.06 \\
7H & 61.3 & -1 & 62.4 & - & - \\
10H & 89.8 & 0.1 & 89.8 & 15.29 & 71.51 \\
339-U1389C- & & & & & \\
2H & 19 & -0.6 & 19.7 & 13.7 & 15.42 \\
5H & 39.5 & 0 & 39.6 & 14.21 & 30.98 \\
8H & 68 & 1.5 & 66.6 & 14.85 & 52.29 \\
339-U1389D- & & & & & \\
3H & 24.5 & 0.8 & 23.8 & 14 & 19.25 \\
6H & 53 & 1.2 & 51.9 & 14.35 & 38.73 \\
9H & 75 & 0.8 & 74.3 & 14.8 & 58.36 \\
\hline
\end{tabular}

* $=+0.1 \mathrm{~m}$ tidal height when mudline Core 339-U1389A-1H was taken. In situ temperatures were determined using TP-Fit software by Martin Heesemann. Thermal resistance was calculated from thermal conductivity data (see "Physical properties") corrected for in situ conditions (see "Downhole measurements" in the "Methods" chapter [Expedition 339 Scientists, 2012b]).

Table T27. Meters composite depth scale, Site U1389. (Continued on next page.)

\begin{tabular}{|c|c|c|c|}
\hline \multirow[b]{2}{*}{ Core } & \multicolumn{2}{|c|}{ Top depth } & \multirow[b]{2}{*}{ Offset (m) } \\
\hline & (mbsf) & (mcd) & \\
\hline \multicolumn{4}{|c|}{ 339-U1389A- } \\
\hline $1 \mathrm{H}$ & 0.00 & 0.14 & 0.14 \\
\hline $2 \mathrm{H}$ & 4.30 & 6.20 & 1.90 \\
\hline $3 \mathrm{H}$ & 13.80 & 17.05 & 3.25 \\
\hline $4 \mathrm{H}$ & 23.30 & 28.39 & 5.09 \\
\hline $5 \mathrm{H}$ & 32.80 & 37.82 & 5.02 \\
\hline $6 \mathrm{H}$ & 42.30 & 48.55 & 6.25 \\
\hline $7 \mathrm{H}$ & 51.80 & 58.90 & 7.10 \\
\hline $8 \mathrm{H}$ & 61.30 & 68.45 & 7.15 \\
\hline $9 \mathrm{H}$ & 70.80 & 79.18 & 8.38 \\
\hline $10 \mathrm{H}$ & 80.30 & 90.28 & 9.98 \\
\hline $11 \mathrm{H}$ & 89.80 & 100.83 & 11.03 \\
\hline $12 \mathrm{X}$ & 97.20 & 108.63 & 11.43 \\
\hline $13 x$ & 101.70 & 114.13 & 12.43 \\
\hline $14 X$ & 111.30 & 123.78 & 12.48 \\
\hline $15 X$ & 120.80 & 134.43 & 13.63 \\
\hline $16 X$ & 130.30 & 144.62 & 14.32 \\
\hline $17 X$ & 139.90 & 155.23 & 15.33 \\
\hline $18 X$ & 149.50 & 164.89 & 15.39 \\
\hline $19 x$ & 159.00 & 175.03 & 16.03 \\
\hline $20 x$ & 168.50 & 187.98 & 19.48 \\
\hline $21 x$ & 178.10 & 200.34 & 22.24 \\
\hline $22 X$ & 187.80 & 213.10 & 25.30 \\
\hline $23 x$ & 197.30 & 224.84 & 27.54 \\
\hline $24 X$ & 206.90 & 234.50 & 27.60 \\
\hline $25 x$ & 216.60 & 244.26 & 27.66 \\
\hline $26 x$ & 226.20 & 254.65 & 28.45 \\
\hline $27 x$ & 235.70 & 265.54 & 29.84 \\
\hline $28 \mathrm{X}$ & 245.30 & 277.50 & 32.20 \\
\hline $29 x$ & 254.90 & 289.02 & 34.12 \\
\hline $30 x$ & 264.60 & 299.24 & 34.64 \\
\hline $31 x$ & 274.20 & 310.96 & 36.76 \\
\hline $32 x$ & 283.80 & 322.46 & 38.66 \\
\hline $33 x$ & 293.40 & 335.97 & 42.57 \\
\hline $34 X$ & 303.00 & 347.87 & 44.87 \\
\hline $35 x$ & 312.20 & 359.33 & 47.13 \\
\hline $36 x$ & 321.80 & 369.03 & 47.23 \\
\hline $37 X$ & 331.40 & 376.74 & 45.34 \\
\hline $38 \mathrm{X}$ & 341.00 & 383.44 & 42.44 \\
\hline $39 x$ & 349.60 & 389.03 & 39.43 \\
\hline
\end{tabular}


Table T27 (continued).

\begin{tabular}{|c|c|c|c|}
\hline \multirow[b]{2}{*}{ Core } & \multicolumn{2}{|c|}{ Top depth } & \multirow[b]{2}{*}{ Offset $(m)$} \\
\hline & (mbsf) & (mcd) & \\
\hline \multicolumn{4}{|c|}{ 339-U1389B- } \\
\hline $1 \mathrm{H}$ & 0.00 & 1.32 & 1.32 \\
\hline \multicolumn{4}{|c|}{ 339-U1389C- } \\
\hline $1 \mathrm{H}$ & 0.00 & 0.00 & 0.00 \\
\hline $2 \mathrm{H}$ & 9.50 & 9.65 & 0.14 \\
\hline $3 \mathrm{H}$ & 19.00 & 19.74 & 0.74 \\
\hline $4 \mathrm{H}$ & 28.50 & 30.29 & 1.79 \\
\hline $5 \mathrm{H}$ & 38.00 & 39.23 & 1.23 \\
\hline $6 \mathrm{H}$ & 47.50 & 48.38 & 0.88 \\
\hline 7H & 57.00 & 58.92 & 1.92 \\
\hline $8 \mathrm{H}$ & 66.50 & 70.58 & 4.08 \\
\hline $9 \mathrm{H}$ & 76.00 & 80.80 & 4.80 \\
\hline $10 \mathrm{H}$ & 85.50 & 92.75 & 7.25 \\
\hline $11 X$ & 95.00 & 104.83 & 9.83 \\
\hline $12 X$ & 103.00 & 113.11 & 10.11 \\
\hline $13 x$ & 112.60 & 124.97 & 12.37 \\
\hline $14 X$ & 122.10 & 136.21 & 14.11 \\
\hline $15 X$ & 131.60 & 146.10 & 14.50 \\
\hline $16 x$ & 141.20 & 155.85 & 14.65 \\
\hline $17 X$ & 150.70 & 167.02 & 16.32 \\
\hline $18 \mathrm{X}$ & 153.70 & 170.85 & 17.15 \\
\hline $19 x$ & 163.30 & 180.49 & 17.19 \\
\hline $20 x$ & 172.90 & 192.54 & 19.64 \\
\hline $21 X$ & 182.50 & 205.00 & 22.50 \\
\hline $22 X$ & 192.00 & 215.60 & 23.60 \\
\hline $23 X$ & 201.70 & 225.17 & 23.47 \\
\hline $24 X$ & 211.30 & 233.82 & 22.52 \\
\hline $25 X$ & 220.90 & 243.98 & 23.08 \\
\hline $26 x$ & 230.50 & 259.29 & 28.79 \\
\hline $27 X$ & 240.10 & 269.98 & 29.88 \\
\hline $28 X$ & 249.70 & 284.79 & 35.09 \\
\hline $29 X$ & 259.30 & 295.09 & 35.79 \\
\hline $30 x$ & 268.90 & 305.98 & 37.08 \\
\hline $31 X$ & 278.50 & 316.17 & 37.67 \\
\hline $32 X$ & 288.10 & 326.49 & 38.39 \\
\hline $33 x$ & 297.70 & 338.29 & 40.59 \\
\hline $34 X$ & 306.90 & 347.64 & 40.74 \\
\hline $35 x$ & 316.50 & 357.44 & 40.94 \\
\hline $36 x$ & 326.10 & 369.24 & 43.14 \\
\hline $37 X$ & 335.70 & 377.04 & 41.34 \\
\hline $38 X$ & 345.30 & 383.84 & 38.54 \\
\hline \multicolumn{4}{|c|}{ 339-U1389D- } \\
\hline $1 \mathrm{H}$ & 0.00 & 0.20 & 0.20 \\
\hline $2 \mathrm{H}$ & 5.50 & 6.04 & 0.54 \\
\hline $3 \mathrm{H}$ & 15.00 & 16.10 & 1.10 \\
\hline $4 \mathrm{H}$ & 24.50 & 26.65 & 2.15 \\
\hline $5 \mathrm{H}$ & 34.00 & 36.00 & 2.00 \\
\hline $6 \mathrm{H}$ & 43.50 & 46.25 & 2.74 \\
\hline $7 \mathrm{H}$ & 53.00 & 55.79 & 2.79 \\
\hline $8 \mathrm{H}$ & 56.00 & 59.02 & 3.02 \\
\hline $9 \mathrm{H}$ & 65.50 & 69.57 & 4.06 \\
\hline $10 \mathrm{H}$ & 75.00 & 81.70 & 6.70 \\
\hline $11 \mathrm{H}$ & 84.50 & 93.75 & 9.25 \\
\hline
\end{tabular}


Table T28. Primary splice tie points for Site U1389. (Continued on next page.)

\begin{tabular}{|c|c|c|c|c|c|c|}
\hline \multirow{2}{*}{$\begin{array}{l}\text { Hole, core, section, } \\
\text { interval }(\mathrm{cm})\end{array}$} & \multicolumn{2}{|c|}{ Depth } & & \multirow{2}{*}{$\begin{array}{l}\text { Hole, core, section, } \\
\text { interval }(\mathrm{cm})\end{array}$} & \multicolumn{2}{|c|}{ Depth } \\
\hline & (mbsf) & (mcd) & & & (mbsf) & $(\mathrm{mcd})$ \\
\hline \multirow[t]{2}{*}{ 339- } & & & & $339-$ & & \\
\hline & & & & U1389C-1H-1, 0 & 0.00 & 0.00 \\
\hline U1389C-1H-2, 80.48 & 2.30 & 2.30 & Tie to & U1389B-1H-1, 97.5 & 0.98 & 2.30 \\
\hline U1389B-1H-6, 14.73 & 7.65 & 8.97 & Tie to & U1389A-2H-2, 126.47 & 7.06 & 8.97 \\
\hline U1389A-2H-6, 143.29 & 13.23 & 15.14 & Tie to & U1389C-2H-4, 99.74 & 15.00 & 15.14 \\
\hline U1389C-2H-6, 18.97 & 17.19 & 17.33 & Tie to & U1389A-3H-1, 28.36 & 14.08 & 17.33 \\
\hline U1389A-3H-7, 10.51 & 22.86 & 26.10 & Tie to & U1389C-3H-5, 35.74 & 25.36 & 26.10 \\
\hline U1389C-3H-7, 60.62 & 28.63 & 29.37 & Tie to & U1389A-4H-1, 97.95 & 24.28 & 29.37 \\
\hline U1389A-4H-6, 90.46 & 31.75 & 36.85 & Tie to & U1389D-5H-1, 85 & 34.85 & 36.85 \\
\hline U1389D-5H-5, 58.44 & 40.58 & 42.58 & Tie to & U1389A-5H-4, 19.94 & 37.56 & 42.58 \\
\hline U1389A-5H-6, 105.91 & 41.47 & 46.49 & Tie to & U1389D-6H-1, 24.8 & 43.75 & 46.49 \\
\hline U1389D-6H-4, 61.11 & 48.61 & 51.36 & Tie to & U1389A-6H-2, 129.2 & 45.10 & 51.36 \\
\hline U1389A-6H-6, 107.35 & 50.95 & 57.21 & Tie to & U1389D-7H-1, 142.39 & 54.42 & 57.21 \\
\hline U1389D-7H-3, 52.5 & 56.05 & 58.84 & Append to & U1389D-8H-1, 0.01 & 56.00 & 59.02 \\
\hline U1389D-8H-7, 68.42 & 65.56 & 68.58 & Tie to & U1389A-8H-1, 12.36 & 61.42 & 68.58 \\
\hline U1389A-8H-5, 127.65 & 68.64 & 75.79 & Tie to & U1389C-8H-4, 97.07 & 71.71 & 75.79 \\
\hline U1389C-8H-6, 149.29 & 75.10 & 79.18 & Append to & U1389A-9H-1, 1.78 & 70.82 & 79.20 \\
\hline U1389A-9H-4, 90 & 76.22 & 84.60 & Tie to & U1389D-10H-3, 7.71 & 77.90 & 84.60 \\
\hline U1389D-10H-7, 46.59 & 83.98 & 90.68 & Tie to & U1389A-10H-1, 40 & 80.70 & 90.68 \\
\hline U1389A-10H-6, 18.56 & 88.10 & 98.08 & Tie to & U1389D-11H-3, 142.55 & 88.84 & 98.08 \\
\hline U1389D-11H-7, 91.55 & 94.11 & 103.35 & Tie to & U1389A-11H-2, 110.87 & 92.32 & 103.35 \\
\hline U1389A-11H-5, 49.17 & 95.99 & 107.02 & Tie to & U1389C-11X-2, 69.3 & 97.19 & 107.02 \\
\hline U1389C-11X-4, 120.96 & 100.71 & 110.54 & Tie to & U1389A-12X-2, 39.51 & 99.11 & 110.54 \\
\hline U1389A-12X-4, 60.2 & 102.03 & 113.46 & Tie to & U1389C-12X-1, 35.33 & 103.35 & 113.46 \\
\hline U1389C-12X-2, 83.06 & 105.33 & 115.44 & Tie to & U1389A-13X-1, 130.96 & 103.01 & 115.44 \\
\hline U1389A-13X-6, 59.61 & 109.72 & 122.14 & Append to & U1389A-14X-2, 1.97 & 111.69 & 124.17 \\
\hline U1389A-14X-2, 114.47 & 112.81 & 125.30 & Tie to & U1389C-13X-1, 33.12 & 112.93 & 125.30 \\
\hline U1389C-13X-7, 71.29 & 122.08 & 134.45 & Append to & U1389A-15X-1, 2.33 & 120.82 & 134.45 \\
\hline U1389A-15X-5, 113.34 & 127.93 & 141.56 & Tie to & U1389C-14X-4, 114.73 & 127.45 & 141.56 \\
\hline U1389C-14X-7, 51.56 & 130.82 & 144.93 & Append to & U1389A-16X-2, 0.96 & 130.82 & 145.39 \\
\hline U1389A-16X-7, 75.64 & 139.07 & 153.39 & Tie to & U1389C-15X-6, 30 & 138.89 & 153.39 \\
\hline U1389C-15X-7, 67.6 & 140.74 & 155.23 & Append to & U1389A-17X-1, 1.91 & 139.92 & 155.25 \\
\hline U1389A-17X-6, 118.01 & 147.85 & 163.18 & Append to & U1389A-18X-1, 1.99 & 149.52 & 164.90 \\
\hline U1389A-18X-6, 81.76 & 157.82 & 173.20 & Tie to & U1389C-18X-2, 85.06 & 156.05 & 173.20 \\
\hline U1389C-18X-4, 7.17 & 158.27 & 175.42 & Tie to & U1389A-19X-1, 38.77 & 159.39 & 175.42 \\
\hline U1389A-19X-7, 49.06 & 167.21 & 183.24 & Tie to & U1389C-19X-3, 80.27 & 166.04 & 183.24 \\
\hline U1389C-19X-7, 60 & 171.73 & 188.92 & Tie to & U1389A-20X-2, 4.59 & 169.45 & 188.92 \\
\hline U1389A-20X-4, 139.26 & 173.79 & 193.27 & Tie to & U1389C-20X-2, 8.74 & 173.63 & 193.27 \\
\hline U1389C-20X-7, 88.45 & 181.84 & 201.48 & Tie to & U1389A-21X-2, 73.11 & 179.24 & 201.48 \\
\hline U1389A-21X-7, 38.15 & 186.39 & 208.63 & Tie to & U1389C-21X-4, 23.44 & 186.13 & 208.63 \\
\hline U1389C-21X-7, 129.94 & 191.70 & 214.19 & Tie to & U1389A-22X-2, 25 & 188.89 & 214.19 \\
\hline U1389A-22X-3, 59.2 & 190.73 & 216.30 & Tie to & U1389C-22X-2, 18 & 192.43 & 216.30 \\
\hline U1389C-22X-7, 143.73 & 201.19 & 224.79 & Append to & U1389A-23X-1, 2.41 & 197.32 & 224.87 \\
\hline U1389A-23X-7, 34.86 & 206.35 & 233.89 & Tie to & U1389C-24X-1, 7.01 & 211.37 & 233.89 \\
\hline U1389C-24X-7, 78.25 & 220.61 & 243.14 & Append to & U1389C-25X-1, 1.36 & 220.91 & 243.99 \\
\hline U1389C-25X-4, 3.35 & 225.43 & 248.51 & Tie to & U1389A-25X-4, 24.99 & 220.85 & 248.51 \\
\hline U1389A-25X-7, 102.62 & 226.10 & 253.75 & Append to & U1389A-26X-1, 1.1 & 226.21 & 254.66 \\
\hline U1389A-26X-5, 79.55 & 233.00 & 261.44 & Tie to & U1389C-26X-2, 64.99 & 232.65 & 261.44 \\
\hline U1389C-26X-6, 73.84 & 238.74 & 267.53 & Tie to & U1389A-27X-2, 104.73 & 237.69 & 267.53 \\
\hline U1389A-27X-7, 51.27 & 244.45 & 274.29 & Tie to & U1389C-27X-4, 40.69 & 244.41 & 274.29 \\
\hline U1389C-27X-7, 51.98 & 249.02 & 278.90 & Tie to & U1389A-28X-1, 140 & 246.70 & 278.90 \\
\hline U1389A-28X-7, 7.11 & 254.27 & 286.48 & Tie to & U1389C-28X-2, 19.45 & 251.39 & 286.48 \\
\hline U1389C-28X-6, 2.5 & 257.23 & 292.31 & Tie to & U1389A-29X-3, 29.12 & 258.19 & 292.31 \\
\hline U1389A-29X-6, 65.79 & 263.06 & 297.18 & Tie to & U1389C-29X-2, 123.55 & 261.40 & 297.18 \\
\hline U1389C-29X-6, 112.25 & 267.28 & 303.07 & Tie to & U1389A-30X-4, 38.86 & 268.43 & 303.07 \\
\hline U1389A-30X-7, 9.58 & 272.64 & 307.28 & Tie to & U1389C-30X-1, 129.61 & 270.20 & 307.28 \\
\hline U1389C-30X-7, 43.22 & 278.13 & 315.21 & Tie to & U1389A-31X-3, 125.51 & 278.46 & 315.21 \\
\hline U1389A-31X-7, 12.5 & 281.93 & 318.68 & Tie to & U1389C-31X-3, 52.33 & 281.01 & 318.68 \\
\hline U1389C-31X-7, 101.85 & 287.51 & 325.18 & Tie to & U1389A-32X-2, 121.89 & 286.52 & 325.18 \\
\hline U1389A-32X-6, 42.5 & 291.73 & 330.39 & Tie to & U1389C-32X-3, 90.25 & 292.00 & 330.39 \\
\hline U1389C-32X-7, 57.5 & 297.12 & 335.50 & Append to & U1389A-33X-1, 2.07 & 293.42 & 335.99 \\
\hline U1389A-33X-3, 87.52 & 297.28 & 339.84 & Tie to & U1389C-33X-2, 124.49 & 299.25 & 339.84 \\
\hline
\end{tabular}


Table T28 (continued).

\begin{tabular}{|c|c|c|c|c|c|c|}
\hline \multirow{2}{*}{$\begin{array}{l}\text { Hole, core, section, } \\
\text { interval }(\mathrm{cm})\end{array}$} & \multicolumn{2}{|c|}{ Depth } & & \multirow{2}{*}{$\begin{array}{l}\text { Hole, core, section, } \\
\text { interval }(\mathrm{cm})\end{array}$} & \multicolumn{2}{|c|}{ Depth } \\
\hline & (mbsf) & (mcd) & & & (mbsf) & (mcd) \\
\hline U1389C-33X-7, 93.91 & 306.44 & 347.03 & Append to & U1389A-34X-1, 2.04 & 303.02 & 347.89 \\
\hline U1389A-34X-7, 80.04 & 311.97 & 356.84 & Append to & U1389C-35X-1, 0 & 316.50 & 357.44 \\
\hline U1389C-35X-4, 127.5 & 322.28 & 363.21 & Tie to & U1389A-35X-3, 88.44 & 316.08 & 363.21 \\
\hline U1389A-35X-6, 68.42 & 320.38 & 367.51 & Append to & U1389A-36X-1, 1.86 & 321.82 & 369.05 \\
\hline U1389A-36X-2, 94.41 & 324.24 & 371.48 & Append to & U1389A-37X-1, 1.98 & 331.42 & 376.76 \\
\hline U1389A-37X-4, 52.58 & 336.19 & 381.52 & Append to & U1389A-38X-1, 0.4 & 341.00 & 383.44 \\
\hline U1389A-38X-4, 66.45 & 345.98 & 388.42 & Append to & U1389A-39X-1, 0.2 & 349.60 & 389.03 \\
\hline
\end{tabular}


Table T29. Excluded magnetic susceptibility data, Site U1389.

\begin{tabular}{|c|c|}
\hline $\begin{array}{l}\text { Core, section, } \\
\text { interval }(\mathrm{cm})\end{array}$ & $\begin{array}{l}\text { Core, section, } \\
\text { interval }(\mathrm{cm})\end{array}$ \\
\hline 339-U1389A- & $5 \mathrm{H}-4,2.44$ \\
\hline $1 \mathrm{H}-1,0$ & $5 \mathrm{H}-4,149.94$ \\
\hline $1 \mathrm{H}-1,150$ & $5 \mathrm{H}-5,0.56$ \\
\hline $1 \mathrm{H}-2,1.59$ & $5 \mathrm{H}-5,153.06$ \\
\hline $1 \mathrm{H}-2,144.09$ & $5 \mathrm{H}-6,0.91$ \\
\hline $1 \mathrm{H}-3,1.98$ & $5 \mathrm{H}-6,150.91$ \\
\hline $1 \mathrm{H}-3,101.98$ & $5 \mathrm{H}-7,0.66$ \\
\hline $2 \mathrm{H}-1,0$ & $5 \mathrm{H}-7,58.16$ \\
\hline $2 \mathrm{H}-1,125$ & $6 \mathrm{H}-1,0$ \\
\hline $2 \mathrm{H}-1,140$ & $6 \mathrm{H}-1,2.5$ \\
\hline $2 \mathrm{H}-1,142.5$ & $6 \mathrm{H}-1,150$ \\
\hline $2 \mathrm{H}-1,145$ & $6 \mathrm{H}-2,1.7$ \\
\hline $2 \mathrm{H}-1,147.5$ & $6 \mathrm{H}-2,151.7$ \\
\hline $2 \mathrm{H}-1,150$ & $6 \mathrm{H}-3,1.69$ \\
\hline $2 \mathrm{H}-2,1.47$ & $6 \mathrm{H}-3,151.69$ \\
\hline $2 \mathrm{H}-2,148.97$ & $6 \mathrm{H}-4,2.1$ \\
\hline $2 \mathrm{H}-3,1.16$ & $6 \mathrm{H}-4,152.1$ \\
\hline $2 \mathrm{H}-3,148.66$ & $6 \mathrm{H}-5,1.99$ \\
\hline $2 \mathrm{H}-4,0.47$ & $6 \mathrm{H}-5,149.49$ \\
\hline $2 \mathrm{H}-4,147.97$ & $6 \mathrm{H}-6,2.35$ \\
\hline $2 \mathrm{H}-5,0.25$ & $6 \mathrm{H}-6,147.35$ \\
\hline $2 \mathrm{H}-5,147.75$ & $6 \mathrm{H}-7,1.59$ \\
\hline $2 \mathrm{H}-6,0.79$ & $6 \mathrm{H}-7,74.09$ \\
\hline $2 \mathrm{H}-6,110.79$ & $7 \mathrm{H}-1,0$ \\
\hline $2 \mathrm{H}-6,145.79$ & $7 \mathrm{H}-1,147.5$ \\
\hline $2 \mathrm{H}-7,0.29$ & $7 \mathrm{H}-1,150$ \\
\hline $2 \mathrm{H}-7,50.29$ & $7 \mathrm{H}-2,2.35$ \\
\hline $3 \mathrm{H}-1,0.86$ & $7 \mathrm{H}-2,149.85$ \\
\hline $3 \mathrm{H}-1,138.36$ & $7 \mathrm{H}-3,1.36$ \\
\hline $3 \mathrm{H}-1,140.86$ & 7H-3, 151.36 \\
\hline $3 \mathrm{H}-1,143.36$ & 7H-4, 1.92 \\
\hline $3 \mathrm{H}-1,145.86$ & $7 \mathrm{H}-4,151.92$ \\
\hline $3 \mathrm{H}-1,148.36$ & $7 \mathrm{H}-5,1.32$ \\
\hline $3 \mathrm{H}-2,0.93$ & 7H-5, 153.82 \\
\hline $3 \mathrm{H}-2,145.93$ & $7 \mathrm{H}-6,2.48$ \\
\hline $3 \mathrm{H}-2,148.43$ & 7H-6, 119.98 \\
\hline $3 \mathrm{H}-3,1.21$ & $7 \mathrm{H}-7,2.26$ \\
\hline $3 \mathrm{H}-3,148.71$ & $7 \mathrm{H}-7,54.76$ \\
\hline $3 \mathrm{H}-4,0.61$ & $8 \mathrm{H}-1,2.36$ \\
\hline $3 \mathrm{H}-4,150.6$ & $8 \mathrm{H}-1,114.86$ \\
\hline $3 \mathrm{H}-5,2.24$ & $8 \mathrm{H}-1,149.86$ \\
\hline $3 \mathrm{H}-5,149.74$ & $8 \mathrm{H}-2,1.95$ \\
\hline $3 \mathrm{H}-6,2.06$ & $8 \mathrm{H}-2,4.45$ \\
\hline $3 \mathrm{H}-6,144.56$ & $8 \mathrm{H}-2,151.95$ \\
\hline $3 \mathrm{H}-7,0.51$ & $8 \mathrm{H}-3,1.21$ \\
\hline $3 \mathrm{H}-7,63.01$ & $8 \mathrm{H}-3,153.71$ \\
\hline $4 \mathrm{H}-1,0.45$ & $8 \mathrm{H}-4,1.05$ \\
\hline $4 \mathrm{H}-1,2.95$ & $8 \mathrm{H}-4,153.55$ \\
\hline $4 \mathrm{H}-1,5.45$ & $8 \mathrm{H}-5,0.15$ \\
\hline $4 \mathrm{H}-1,150.45$ & $8 \mathrm{H}-5,150.15$ \\
\hline $4 \mathrm{H}-2,0.95$ & $8 \mathrm{H}-6,1.34$ \\
\hline $4 \mathrm{H}-2,150.95$ & $8 \mathrm{H}-6,151.34$ \\
\hline $4 \mathrm{H}-3,1.28$ & $8 \mathrm{H}-7,0.31$ \\
\hline $4 \mathrm{H}-3,151.28$ & $8 \mathrm{H}-7,70.31$ \\
\hline $4 \mathrm{H}-4,0.06$ & $9 \mathrm{H}-1,1.78$ \\
\hline $4 \mathrm{H}-4,151.17$ & $9 \mathrm{H}-1,146.78$ \\
\hline $4 \mathrm{H}-5,0.51$ & $9 \mathrm{H}-2,2.18$ \\
\hline $4 \mathrm{H}-5,150.51$ & $9 \mathrm{H}-2,149.68$ \\
\hline $4 \mathrm{H}-6,0.46$ & $9 \mathrm{H}-3,0.81$ \\
\hline $4 \mathrm{H}-6,147.96$ & $9 \mathrm{H}-3,153.31$ \\
\hline $4 \mathrm{H}-7,0.17$ & $9 \mathrm{H}-4,0$ \\
\hline $4 \mathrm{H}-7,60.17$ & $9 \mathrm{H}-4,135$ \\
\hline $5 \mathrm{H}-1,0.86$ & $9 \mathrm{H}-4,155$ \\
\hline $5 \mathrm{H}-1,150.86$ & $9 \mathrm{H}-5,1.42$ \\
\hline $5 \mathrm{H}-2,1.84$ & $9 \mathrm{H}-5,153.92$ \\
\hline $5 \mathrm{H}-2,151.84$ & $9 \mathrm{H}-6,1.93$ \\
\hline $5 \mathrm{H}-3,1.65$ & $9 \mathrm{H}-6,146.93$ \\
\hline $5 \mathrm{H}-3,154.15$ & $9 \mathrm{H}-7,1.43$ \\
\hline
\end{tabular}

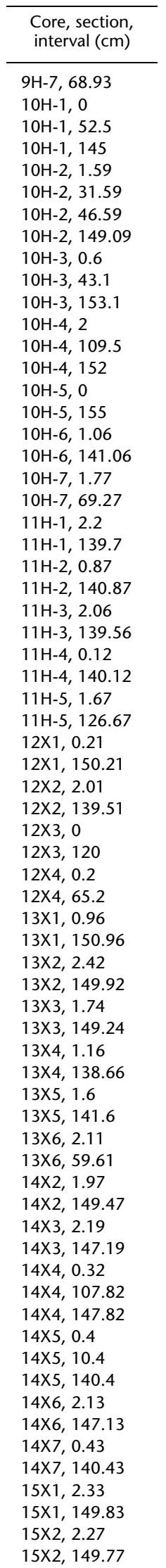

\begin{tabular}{|c|c|}
\hline $\begin{array}{l}\text { Core, section, } \\
\text { interval }(\mathrm{cm})\end{array}$ & $\begin{array}{l}\text { Core, section, } \\
\text { interval }(\mathrm{cm})\end{array}$ \\
\hline $15 \times 3,0.05$ & $20 \times 2,2.09$ \\
\hline $15 \times 3,150.05$ & $20 \times 2,149.59$ \\
\hline $15 \times 4,2.19$ & $20 \times 3,1.96$ \\
\hline $15 \times 4,139.69$ & $20 \times 3,149.46$ \\
\hline $15 \times 5,0.84$ & $20 \times 4,1.76$ \\
\hline $15 \times 5,148.34$ & $20 \times 4,139.26$ \\
\hline $15 \times 6,0.12$ & $20 \times 5,1.49$ \\
\hline $15 \times 6,77.62$ & $20 \times 5,128.99$ \\
\hline $16 \times 2,0.96$ & $20 \times 6,0.96$ \\
\hline $16 \times 2,148.46$ & $20 \times 6,130.96$ \\
\hline $16 \times 3,0.76$ & $20 \times 7,2.49$ \\
\hline $16 \times 3,150.76$ & $20 \times 7,59.99$ \\
\hline $16 \times 4,2.29$ & $21 \times 1,1.67$ \\
\hline $16 \times 4,149.79$ & $21 \times 1,39.17$ \\
\hline $16 \times 5,1.78$ & $21 \times 2,0.61$ \\
\hline $16 \times 5,139.28$ & $21 \times 2,148.11$ \\
\hline $16 \times 6,1.11$ & $21 \times 3,0.11$ \\
\hline $16 \times 6,148.61$ & $21 \times 3,150.11$ \\
\hline $16 \times 7,0.64$ & $21 \times 4,0.63$ \\
\hline $16 \times 7,85.64$ & $21 \times 4,150.63$ \\
\hline $17 X 1,1.91$ & $21 \times 5,2.45$ \\
\hline $17 \times 1,74.41$ & $21 \times 5,139.95$ \\
\hline $17 \times 2,0.2$ & $21 \times 6,1.3$ \\
\hline $17 X 2,150.2$ & $21 \times 6,148.8$ \\
\hline $17 \times 3,2.44$ & $21 \times 7,0.65$ \\
\hline $17 X 3,149.94$ & $21 \times 7,130.65$ \\
\hline $17 \times 4,1.95$ & $22 \times 2,0$ \\
\hline $17 \times 4,139.45$ & $22 \times 2,150$ \\
\hline $17 \times 5,0.77$ & $22 \times 3,1.59$ \\
\hline $17 \times 5,148.27$ & $22 \times 3,149.09$ \\
\hline $17 \times 6,0.51$ & $22 \times 4,1.41$ \\
\hline $17 \times 6,118.01$ & $22 \times 4,138.91$ \\
\hline $18 \times 1,1.99$ & $22 \times 5,1.16$ \\
\hline $18 \times 1,4.49$ & $22 \times 5,148.66$ \\
\hline $18 \times 1,6.99$ & $22 \times 6,1.7$ \\
\hline $18 \times 1,9.49$ & $22 \times 6,149.2$ \\
\hline 18X1, 11.99 & $22 \times 7,0.97$ \\
\hline $18 \times 1,149.49$ & $22 \times 7,110.97$ \\
\hline $18 \times 2,1.33$ & $23 \times 1,2.41$ \\
\hline $18 \times 2,148.83$ & $23 \times 1,147.41$ \\
\hline $18 \times 3,0.83$ & $23 \times 2,1.01$ \\
\hline $18 \times 3,148.33$ & $23 \times 2,148.51$ \\
\hline $18 \times 4,0.08$ & $23 \times 3,0.5$ \\
\hline $18 \times 4,2.58$ & $23 \times 3,150.5$ \\
\hline $18 \times 4,5.08$ & $23 \times 4,2.44$ \\
\hline $18 \times 4,140.08$ & $23 \times 4,139.94$ \\
\hline $18 \times 5,1.65$ & $23 \times 5,2.08$ \\
\hline $18 \times 5,149.15$ & $23 \times 5,149.58$ \\
\hline $18 \times 6,1.76$ & $23 \times 6,0$ \\
\hline $18 \times 6,81.76$ & $23 \times 6,120$ \\
\hline $19 \times 1,1.27$ & $23 \times 7,2.36$ \\
\hline 19X1, 63.77 & $23 \times 7,59.86$ \\
\hline $19 \times 2,1.91$ & $24 \times 2,0$ \\
\hline $19 \times 2,149.41$ & $24 \times 2,150$ \\
\hline $19 \times 2,149.85$ & $24 \times 3,2.5$ \\
\hline $19 \times 3,1.91$ & $24 \times 3,150$ \\
\hline $19 \times 3,149.41$ & $24 X 4,1.72$ \\
\hline $19 \times 4,1.77$ & $24 X 4,149.22$ \\
\hline $19 \times 4,106.77$ & $24 \times 5,0.15$ \\
\hline $19 \times 5,1.33$ & $24 \times 5,150.15$ \\
\hline $19 \times 5,138.83$ & $24 \times 6,1.74$ \\
\hline $19 \times 6,1.15$ & $24 \times 6,141.74$ \\
\hline $19 \times 6,148.65$ & $24 \times 7,2.33$ \\
\hline $19 \times 7,1.56$ & $24 X 7,84.83$ \\
\hline 19X7, 126.56 & $25 \times 2,0.37$ \\
\hline $20 \times 1,0$ & $25 \times 2,147.87$ \\
\hline $20 \times 1,2.5$ & $25 \times 3,0.13$ \\
\hline $20 \times 1,90$ & $25 \times 3,150.13$ \\
\hline
\end{tabular}

Only a portion of this table appears here. The complete table is available in ASCII. 